Florida International University FIU Digital Commons

4-9-2001

\title{
Calle Ocho revived : artists studios commemorate the role of Cuban exiles (1960-1973) in the development of Calle Ocho
}

Pilar L. Benitez

Florida International University

DOI: $10.25148 /$ etd.FI14050499

Follow this and additional works at: https://digitalcommons.fiu.edu/etd

Part of the Architecture Commons

\section{Recommended Citation}

Benitez, Pilar L., "Calle Ocho revived : artists studios commemorate the role of Cuban exiles (1960-1973) in the development of Calle Ocho" (2001). FIU Electronic Theses and Dissertations. 1508.

https://digitalcommons.fiu.edu/etd/1508 
FLORIDA INTERNATIONAL UNIVERSITY

Miami, Florida

CALLE OCHO REVIVED: ARTISTS STUDIOS COMMEMORATE

THE ROLE OF CUBAN EXILES (1960-1973) IN

THE DEVELOPMENT OF CALLE OCHO

A thesis is submitted in partial fulfillment of the

requirements for the degree of

MASTER OF ARCHITECTURE

by

Pilar L. Benitez 
To: Dean William McMinn

School of Architecture

This thesis, written by Pilar L. Benitez, and entitled Calle Ocho Revived: Artists Studios Commemorate

The Role of Cuban Exiles (1960-1973) in the Development of Calle Ocho; having been approved in respect to style and intellectual content, is referred to you for judgment.

We have read this thesis and recommend that it be approved.

\title{
Marta Canaves
}

\section{Sose Casanova}

John Stuart, Major Prolessor

Date of Defense: April 9, 2001

The thesis of Pilar L. Benitez is approvęd.

Dean William McMinn
School of Architecture

\author{
Interim Dean Samuel b. Shapiro \\ Divisur of Graduate Studies
}

Florida International University, 2001 
DEDICATION

I dedicate this thesis to my parents. 
ACKNOWLEDGMENTS

I wish to thank my son Eric for his support and patience and my daughter Alexis for her kind encouraging words. I also like to express my gratitude to Juan Carlos Martin, Gerardo Martinez and Maria Teresa Rubio who providing me with the technical support required to complete this manuscript. I would also like to thank the members of my committee for their guidance. 
ABSTRACT OF THE THESIS

\section{CALLE OCHO REVIVED: ARTISTS STUDIOS COMMEMORATE}

THE ROLE OF CUBAN EXILES (1960-1973) IN THE

\section{DEVELOPMENT OF CALLE OCHO}

by

Pilar L. Benitez

Florida International University, 2001

Miami, Florida

\section{Professor John Stuart, Major Professor}

The purpose of this study was to learn about the historical development of Eight Street in order to use this information in the revitalization of this area with the new migration of artists.

The area of study concentrated on Eight Street from 13th to 17th Avenues. The historical origins that formed Eight Street were research at local archives and the history of each property was obtained through the City of Miami Property Appraiser's.

This study demonstrated a cyclical pattern prompted by the economical success of the immigrant group. The 1960 Cuban migration brought an era of life to Eight Street. As the Cubans became successful they left the area causing a decline. Presently the area is witnessing a migration of artists that may bring it new life.

The thesis retrofits buildings in this area to create a series of artist studios. These studios are designed using elements of 1960 Cuban urbanity, an era of robust urban life for this street. 
I. INTRODUCTION

II. CUBANS IN MIAMI 3

Endnotes..

III. EARLY HISTORY OF EIGHTH STREET AND RIVERSIDE..........13

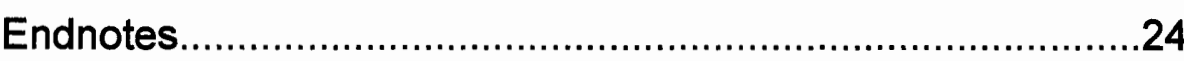

IV. CUBAN MIGRATION 1960 TO 1973.......................................26

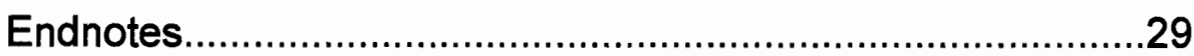

V. CALLE OCHO: TRANSFORMATION 1960-1973.........................30

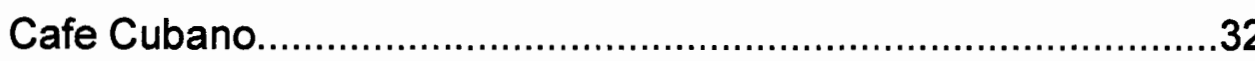

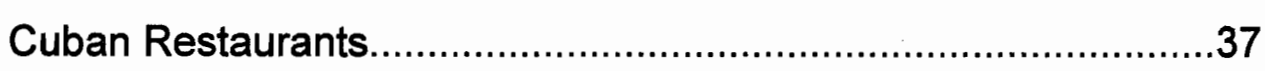

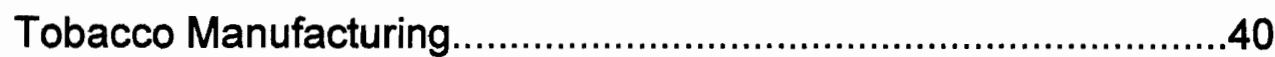

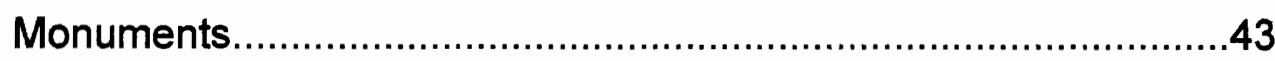

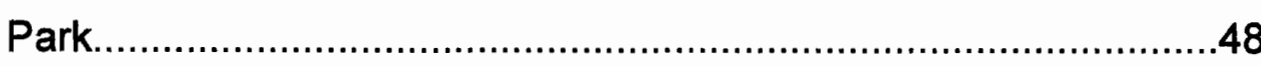

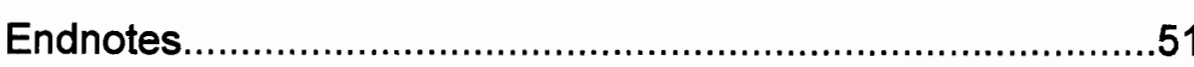

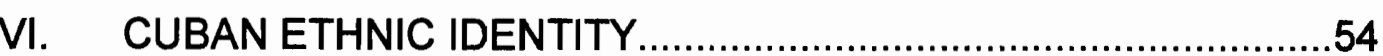

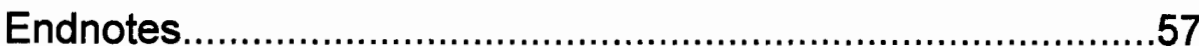

VII. PROPERTY HISTORY ON CALLE OCHO...................................58

South Even Numbers..............................................................60

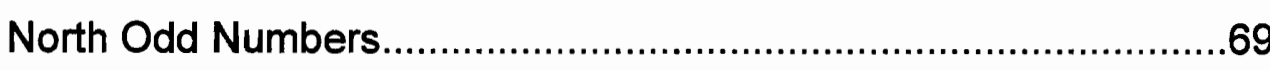

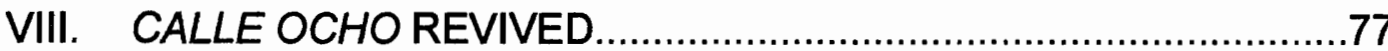

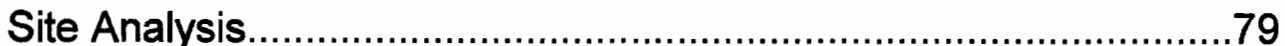

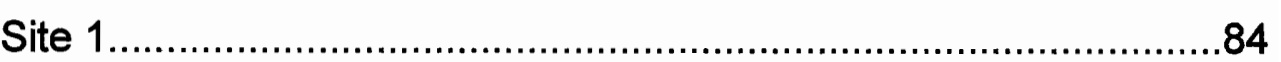

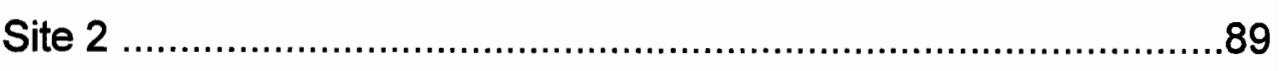

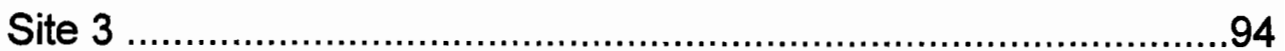

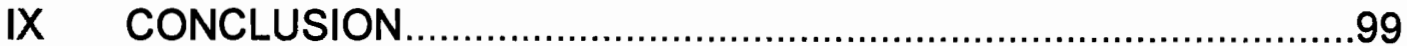


1. 1912 Overseas Railroad

Peters, Thelma. 1984. Miami 1909. Miami: Banyan Books Inc

2. Postcard Bacardi Rum University of Miami Cuban Collection.

3. "General Machado"

University of Miami, Cuban Collection.

4. Pan Am First Flight .... University of Miami, Cuban Collection.

5. Map indicates the consulate location City of Miami Archives.

Glass, lan 1977 Knock, Knock Who's There at Villa Paula?

The Miami Herald, 31 October.

7. Riverside, S.W. $8^{\text {th }}$ Street $/ 2^{\text {nd }}$ Avenue South Florida Historical Museum Archives.

8. Riverside, S.W. $8^{\text {th }}$ Street $/ 37^{\text {th }}$ Avenue South Florida Historical Museum Archives.

9. Riverside, S.W. $8^{\text {th }}$ Street South Florida Historical Museum

0. $8^{\text {th }}$ Street $/ 2^{\text {nd }}$ Avenue in 1896 Moore Parks, Arva. 1993. Calle Ocho: Interpretive Center Concept. Miami, Florida: City of Miami.

11. Map of Miami 1909

Peters, Theima. 1984. Miami 1909. Miami: Banyan Books Inc.

12. Development East of $2^{\text {nd }}$ Avenue Peters, Thelma. 1984. Miami 1909. Miami: Banyan Books Inc.

Indian Camp west of $2^{\text {nd }}$ Avenue

Peters, Thelma. 1984. Miami 1909. Miami: Banyan Books Inc 
14. Isodore Cohen's Store...... Peters, Thelma. 1984. Miami 1909. Miami: Banyan Books inc.

5. Samuel Belcher and his family

Peters, Thelma. 1984. Miami 1909. Miami: Banyan Books Inc

16. Lawrence Estate Auction 1913 Liebman, Nancy. 1993. Calle Ocho Historic District Concept Miami, Florida : City of Miami.

17. Lawrence Estate Plot Plan City of Miami Archives.

18. Westmooreland Auction Announcement Liebman, Nancy. 1993. Calle Ocho Historic District Concept, Miami, Florida : City of Miami.

19. Plot Plan. City of Miami Archives.

20. Flagler Bridge 1950 George, Dr. Paul. 1991. The Paul George Walking Tour of East Little Havana. Miami: The Historic Association of Southern Florida.

21. Trolley on Flagler George, Dr. Paul. 1991. The Paul George Walking Tour of East Little Havana. Miami: The Historic Association of Southern Florida.

22. Tamiami Trail 1950

South Florida Historical Museum

23. Tamiami Trail 1951 South Florida Historical Museum

24. Tower Theater 1931 South Florida Historical Museum

25. 1951 Riverside/15th Avenue. South Florida Historical Museum

26. 8th Street/ 22 Avenue 1961

South Florida Historical Museum 
28. Cuban refugees arrive in Miami...

29. 8th Street/ 6th Avenue 1969

South Florida Historical Museum

30. 8th Street/ 17th Avenue 1968 South Florida Historical Museum

31. Documents Illustrating Cuban Owned Businesses

.32 by author

32. 1950's Open-Air Cafe South Florida Historical Museum

33. Havana Vieja coffee counters.

34. 1960 Cafe Window. South Florida Historical Museum

35. Cafe Windows Photo by author.

36. Cafe Windows

Photo by author.

37. Cafe Windows Photo by Author.

38. Cafe Windows .36 Photo by Author

39. El Pub decorative map..........................................................................38 George, Dr. Paul. Exploring the Culture of Little Havana. University of Miami. http://uww.education miami.edu.

40. Sandwich counter with hanging hams George, Dr. Paul. Exploring the Culture of Little Havana. University of Miami. http://uww.education.miami.edu. 
41. Cigar Rolling

Gonzalez-Pando, Miguel. Greater Miami: Spirit of Cuban Enterprise. Fort Lauderdale : Copperfield Publication, Inc.

42. Cigar Rolling

Gonzalez-Pando, Miguel. Greater Miami: Spirit of Cuban Enterprise. Fort Lauderdale : Copperfield Publication, Inc.

43. Typical cigar manufacturing on Calle Ocho.

Photo by Author.

44. Typical cigar display Photo by Author

45. Cuban Memorial Boulevard

Photo by Author

46. Cuban Memorial Boulevard Photo by Author

47. Isla de Cuba Memorial

Photo by Author

48. Nestor Isquierdo Memorial Photo by Autrhor

49. Jose Marti Memorial. George, Dr. Paul. Exploring the Culture of Little Havana. University of Miami. http://unw.education.miami.edu.

50. Monumento a Las Madres...

George, Dr. Paul. Exploring the Culture of Little Havana University of Miami. http://uww.education.miami.edu.

51. Ceiba Tree George, Dr. Paul. Exploring the Culture of Little Havana. University of Miami. http://unww.education.miami.edu.

52. Domino Players George, Dr. Paul. Exploring the Culture of Little Havana. University of Miami. http://www.education.miami.edu. 
53. Chess Players.......................................................................48 George, Dr. Paul. Exploring the Culture of Little Havana. University of Miami. http://wnw.education.miami.edu.

54. Domino Park Photo by Author.

5. Fenced Domino Park Photo by Author.

56. Remodeled Tower Theater. Photo by Author.

57. Sculpture representative of the History of Calle Ocho. .78

58. Historial Significance Analysis.

59. Ethnic Jewish Businesses Analysis.

60. Ethnic Cuban Establishments Analysis .. .80

61. Ethnic Cuban Establishments Analysis . .80

62. Ethic Cuban Businesses Present Analysis

63. Public and Open Spaces Analysis. 81

64. Artists Related Analysis.

65. Visual Assestment Analysis. . .82

66. Site Location Analysis.

67. Site 1 Photos.

68. Preliminary Model .85

69. Preliminary Model . .85

70. Preliminary Plan $\ldots 85$

71. South Elevation . .85

72. West Elevation 
73. Model

75. Site Plan

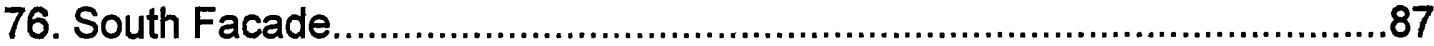

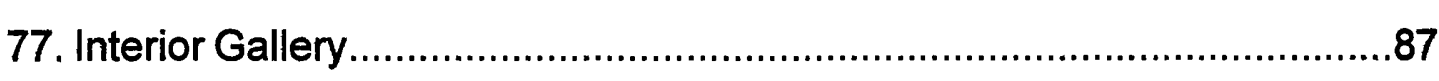

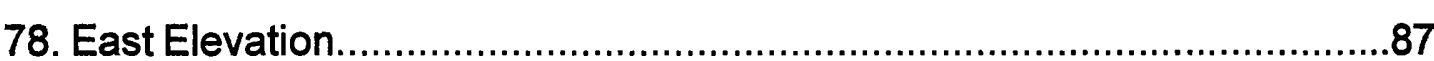

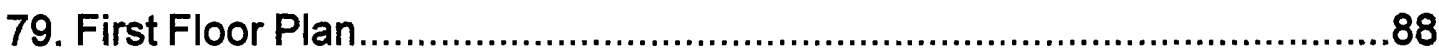

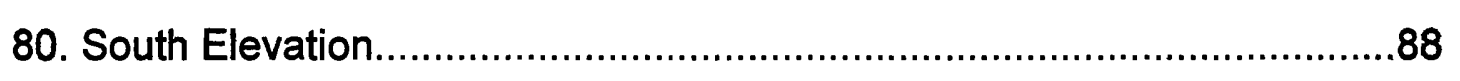

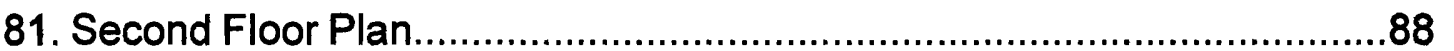

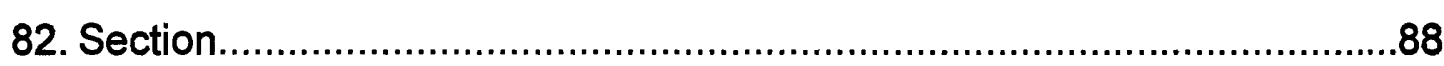

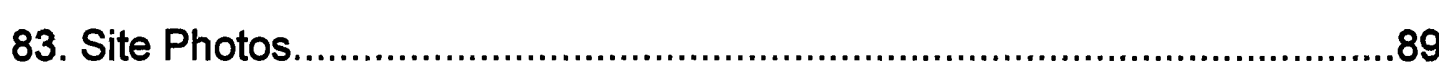

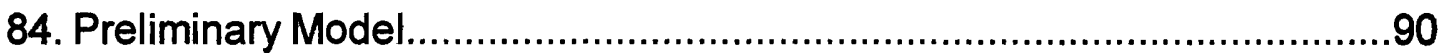

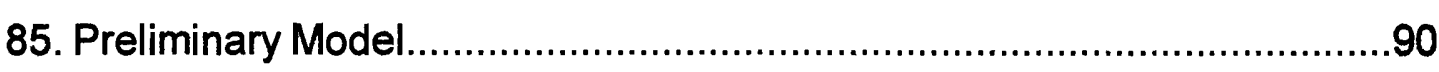

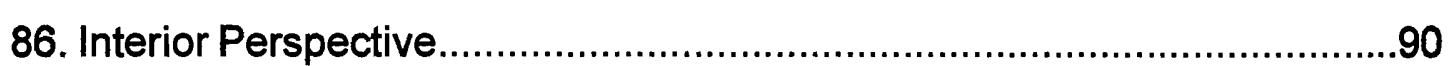

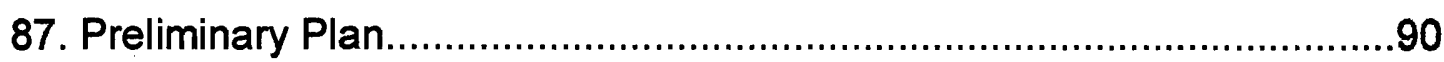

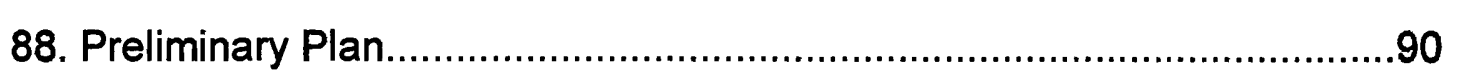

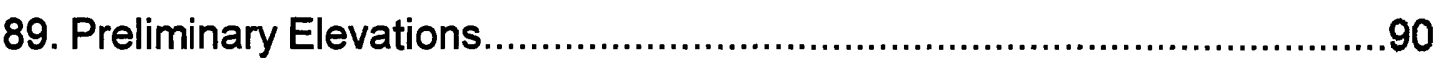

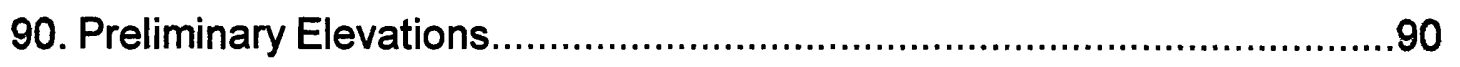

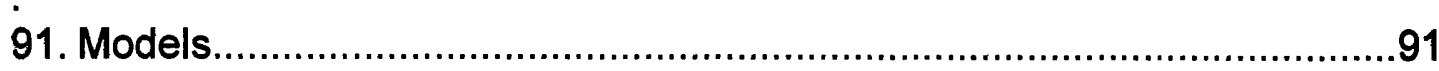

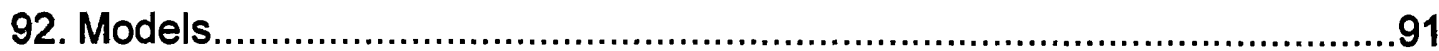

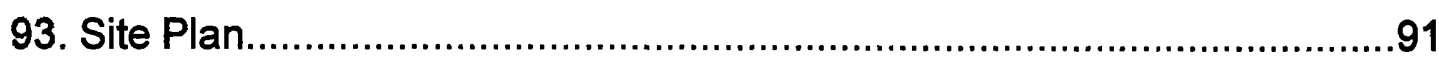

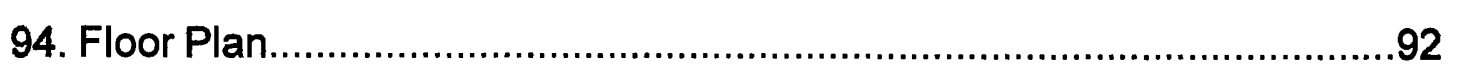


95. Interior of Studio Closed

97. Interior of Studio Opened

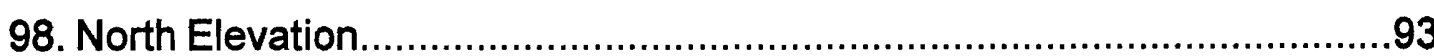

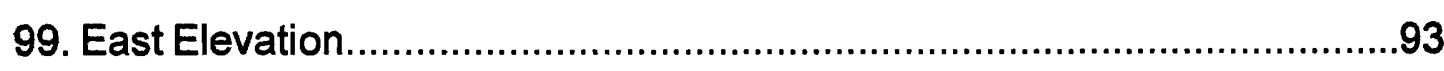

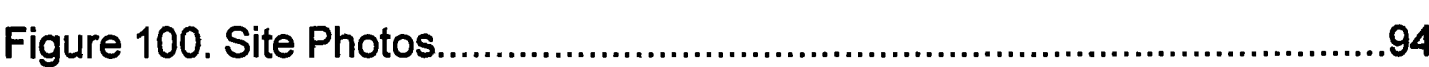

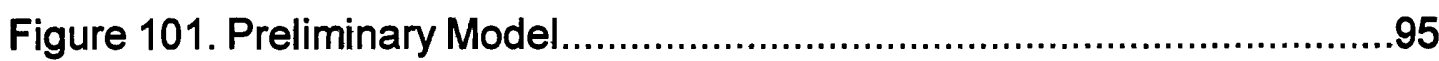

Figure 102. Preliminary Model................................................................95

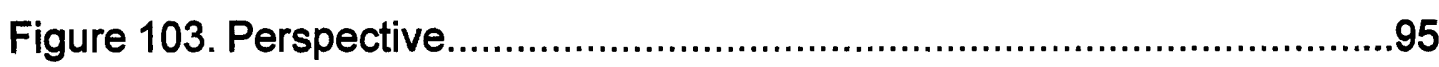

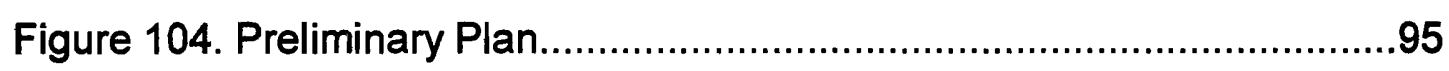

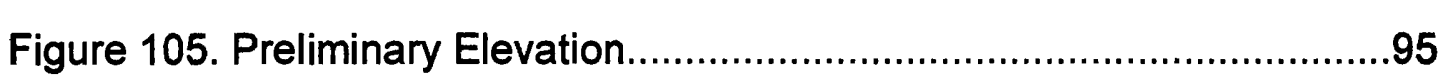

Figure 106. Exterior Perspective.........................................................95

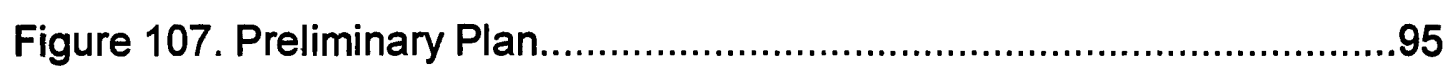

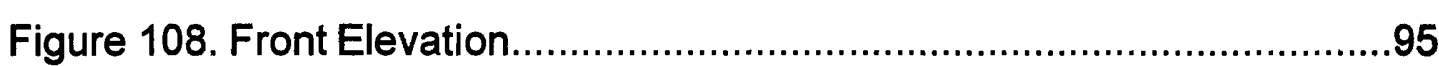

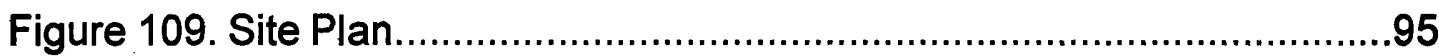

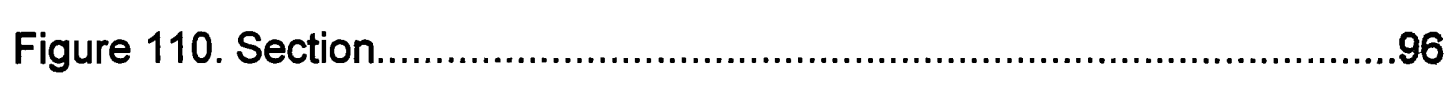

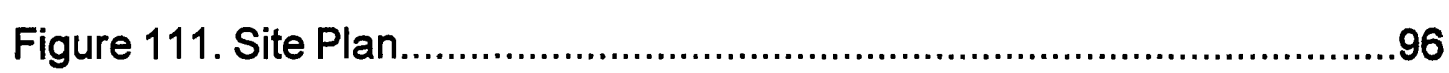

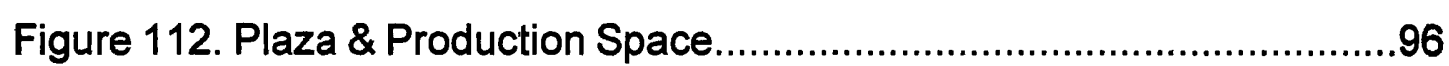

Figure 113. Plaza \& Production Space ....................................................96

Figure 114. Exterior Studio Work Area................................................ 97

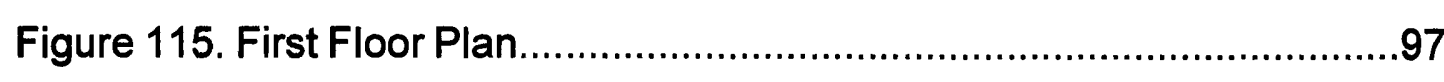

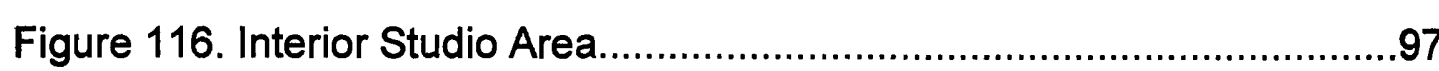


117. South Elevation..

119. Section...

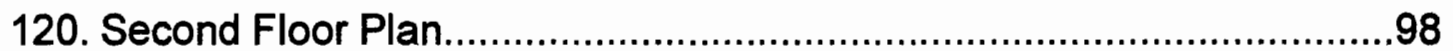

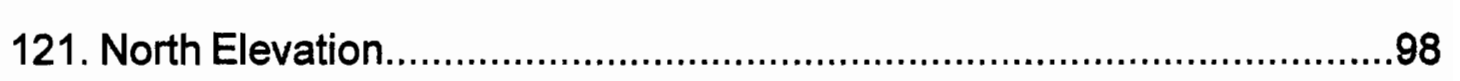

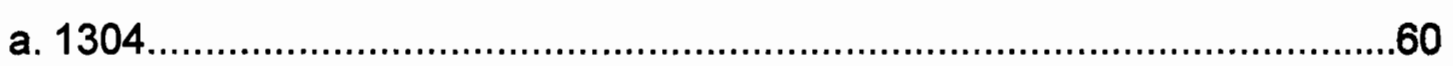

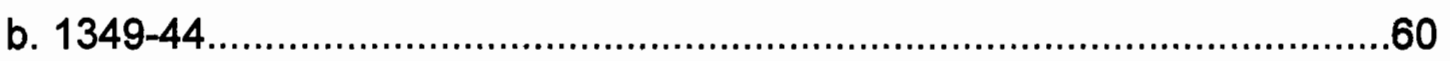

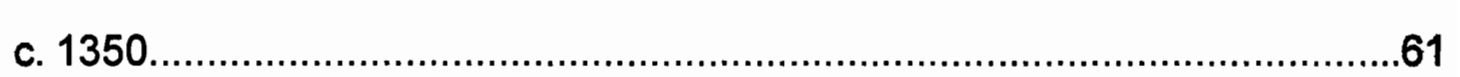

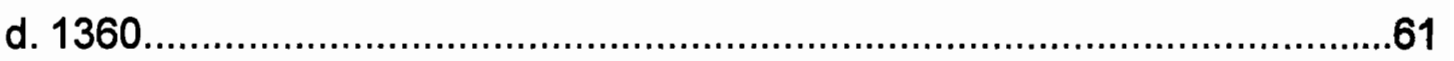

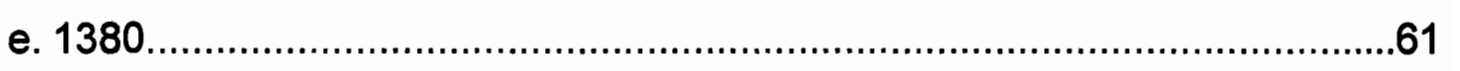

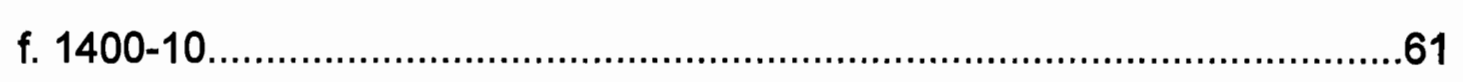

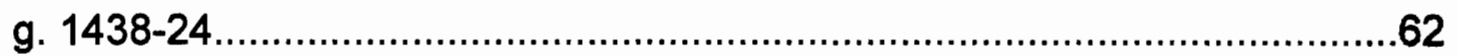

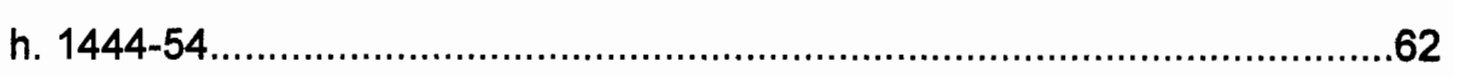

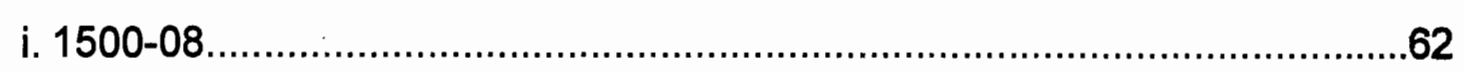

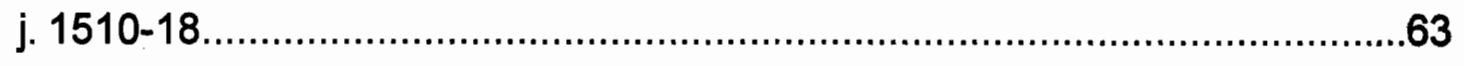

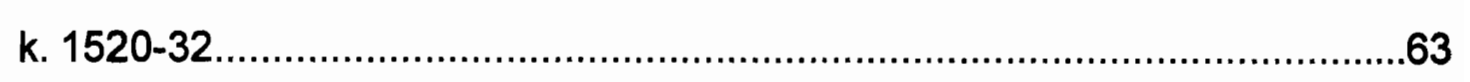

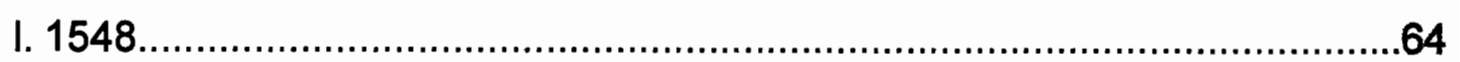

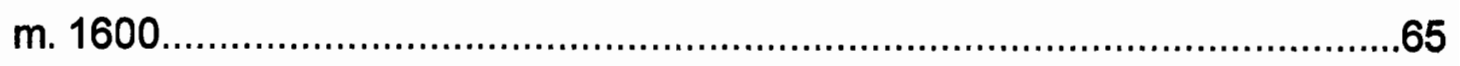

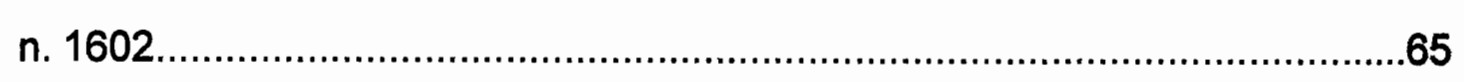

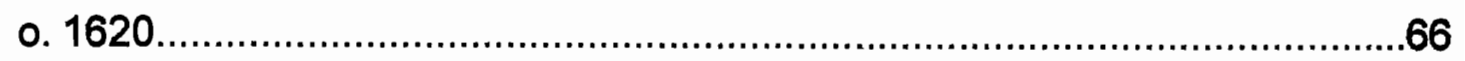

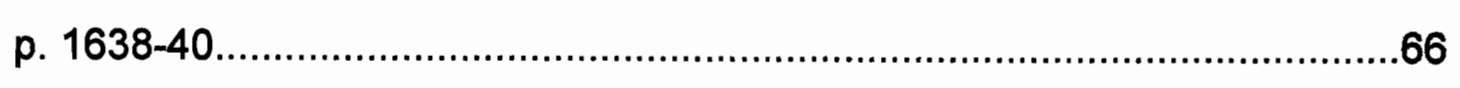

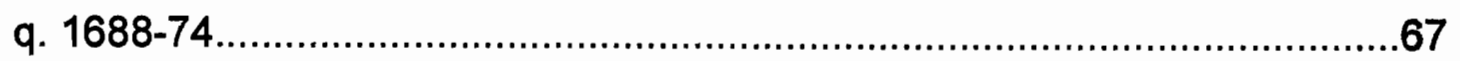


r. 1325.

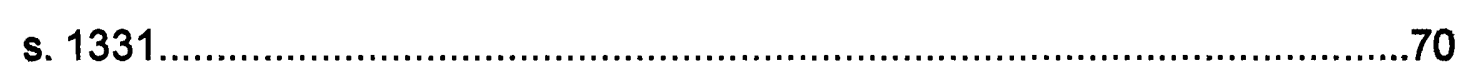

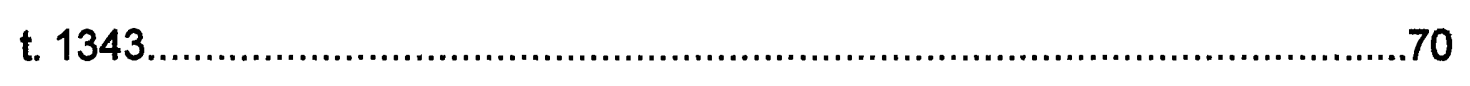

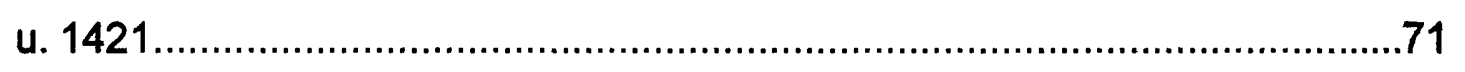

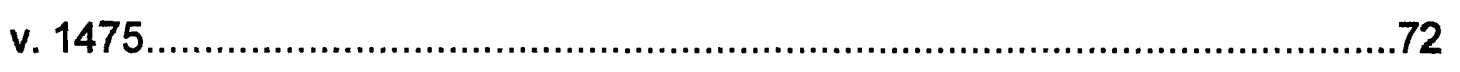

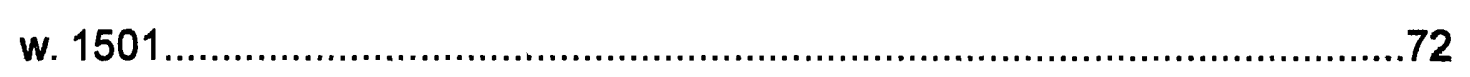

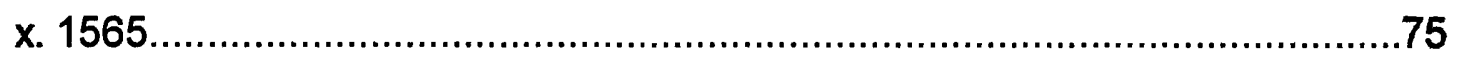

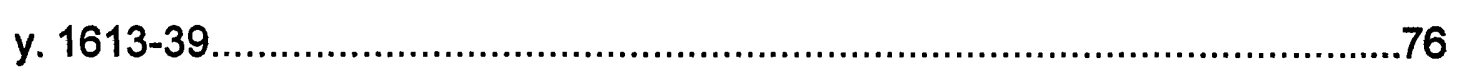

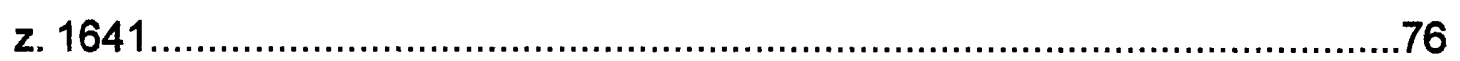




\section{INTRODUCTION}

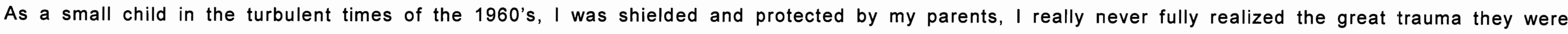

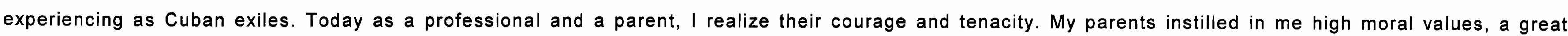
respect for education and a love for my Cuban roots. The topic of this thesis sets the context for their story.

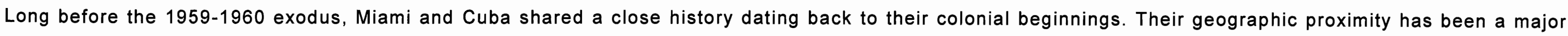

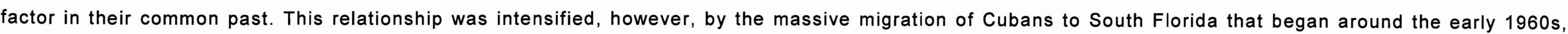

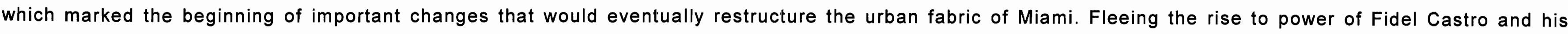

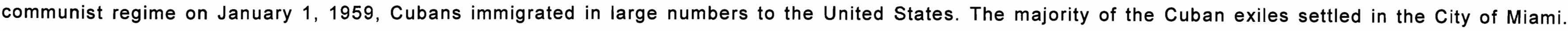

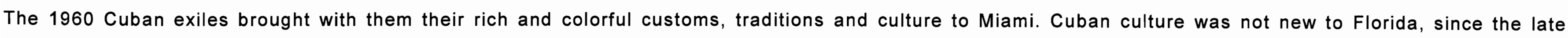
1800s, Cuban tobacco manufactures fled the island and settled in Key West and Tampa, however, the Cuban immigration of the 1960's was the largest.

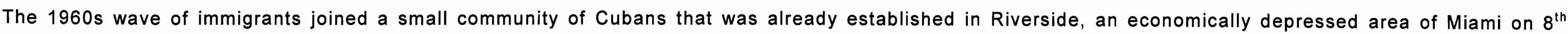

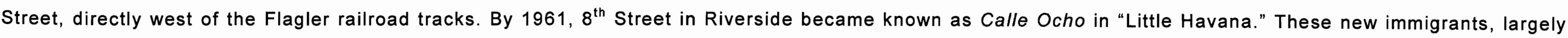

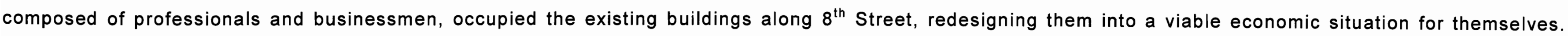

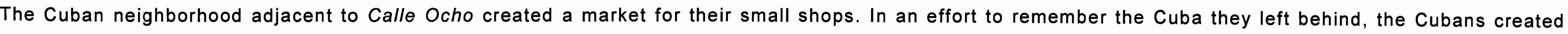

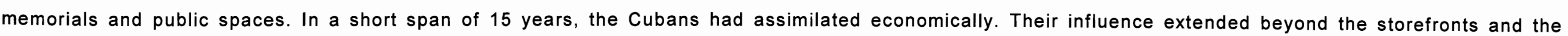
memorials they created on Calle Ocho spreading into all of South Florida. In many ways, they created an economic boom. 


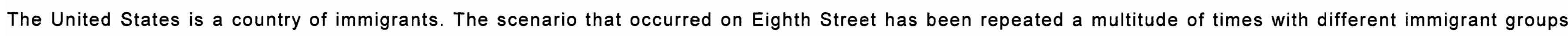

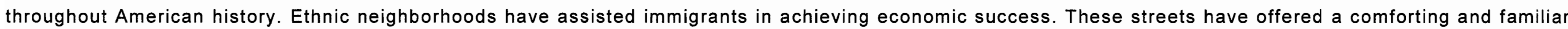

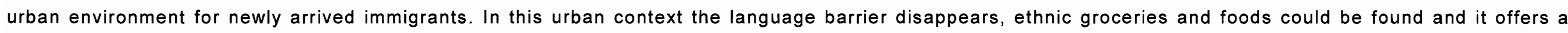

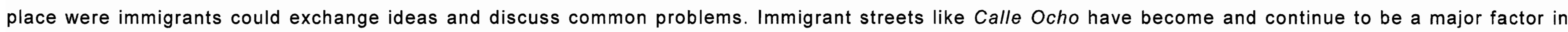
the formation of great American cities like Miami, Los Angeles, New York and New Jersey. 


\section{CHAPTER 1:}

\section{CUBANS AND MIAMI:}

\section{SHARED PAST AND EARLY CUBANS IN MIAMI}

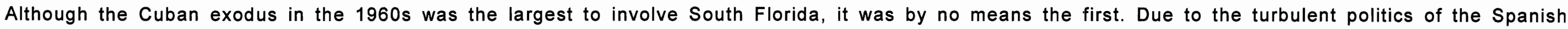

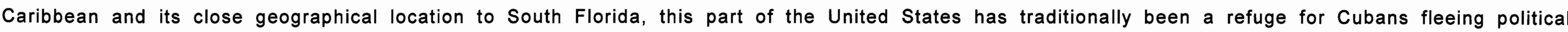
repression. ${ }^{1}$

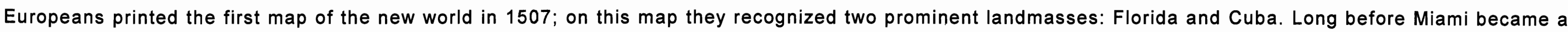

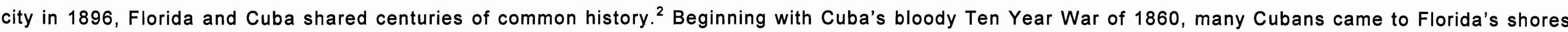

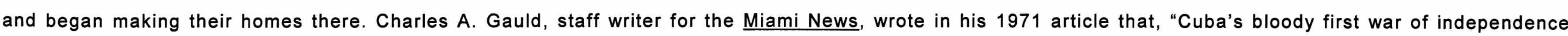

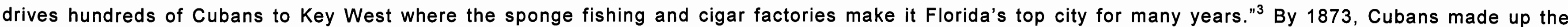
majority of the population of Key West. ${ }^{4}$

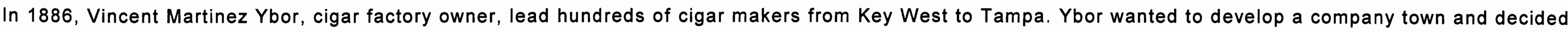

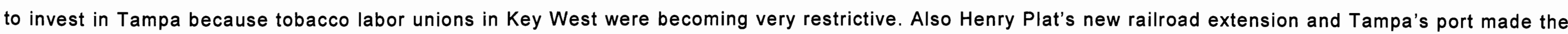

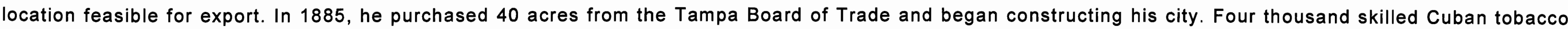

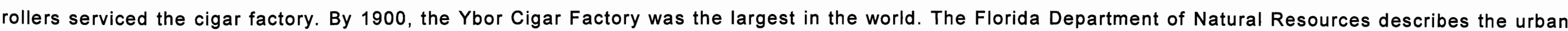




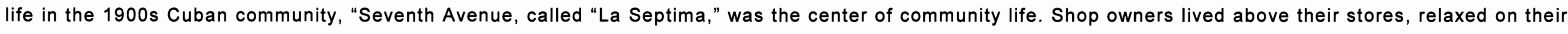

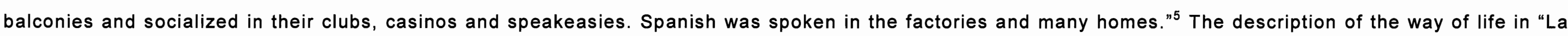

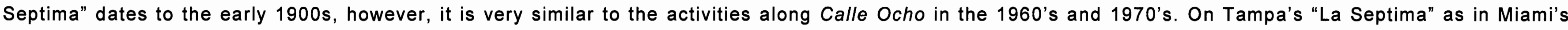

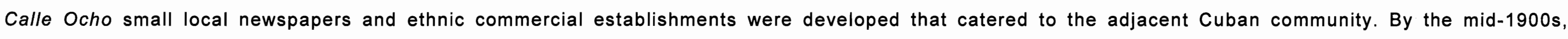
twenty percent of Tampa's population was of Cuban ancestry. ${ }^{6}$

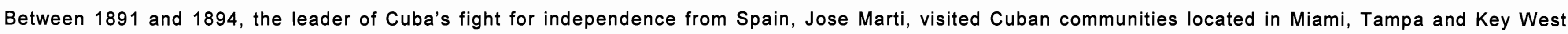

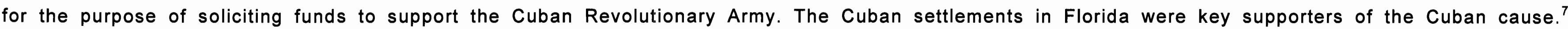

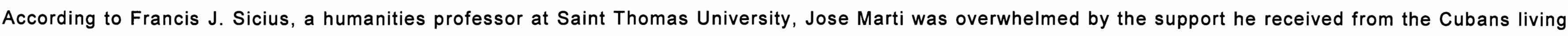

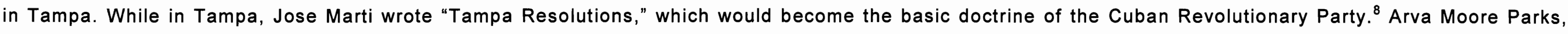

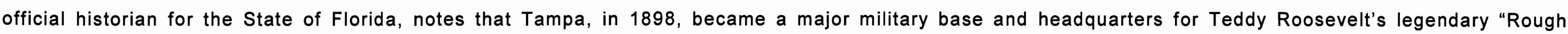

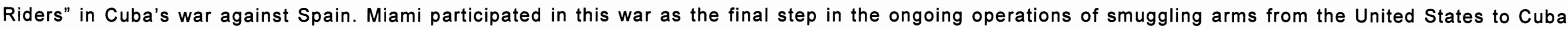
and as a host for military camps. ${ }^{9}$

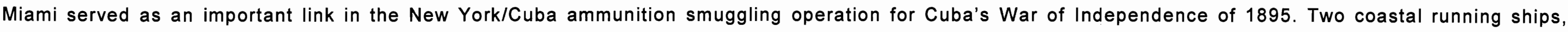

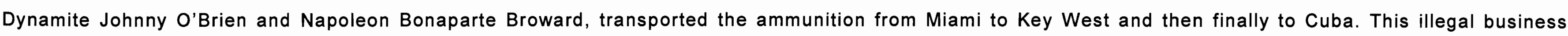

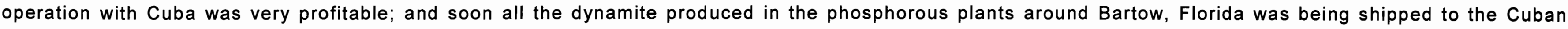
revolutionaries. ${ }^{10}$

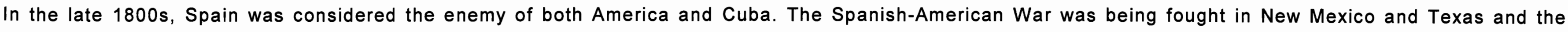

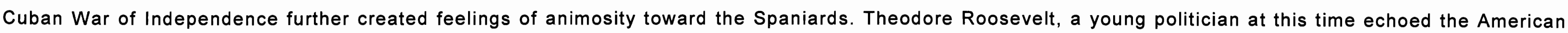




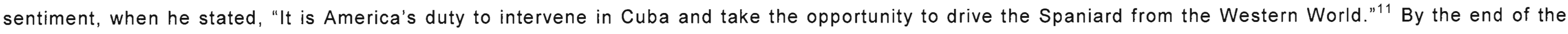
Cuban War of Independence in the early 1900 s, the United States had invested heavily in Cuba, and the two countries were brought even closer together. ${ }^{12}$

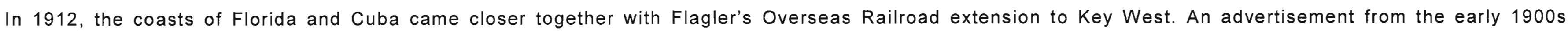

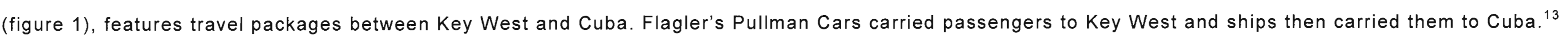

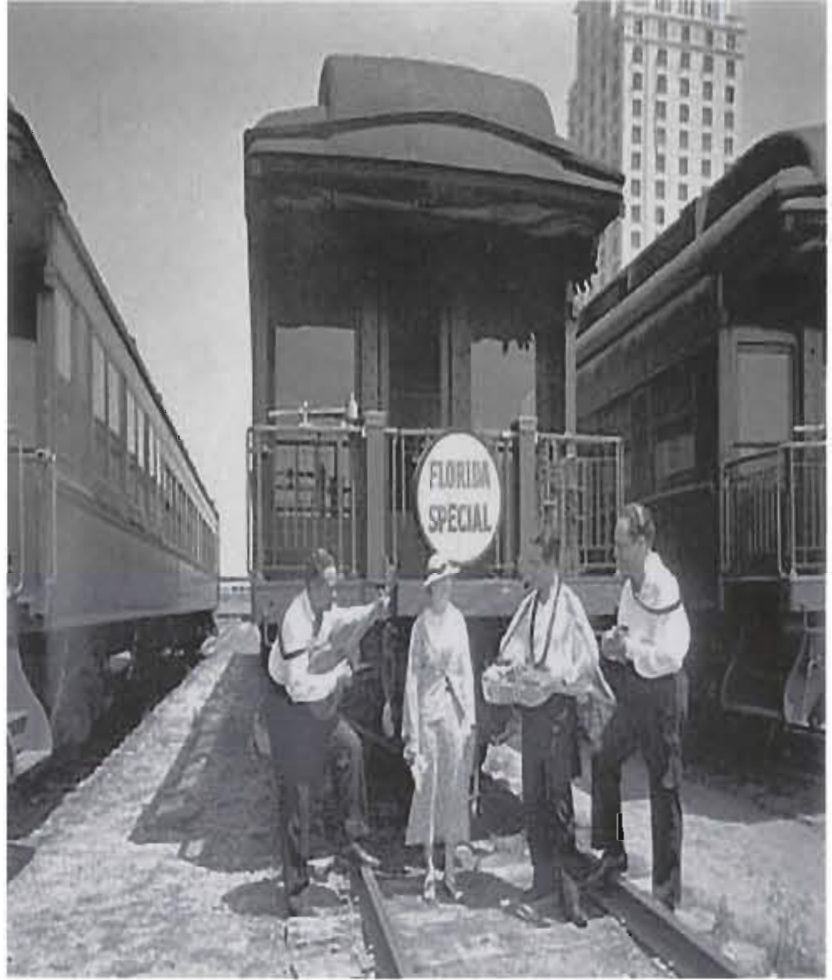

Figure 1. 1912 Overseas Railroad

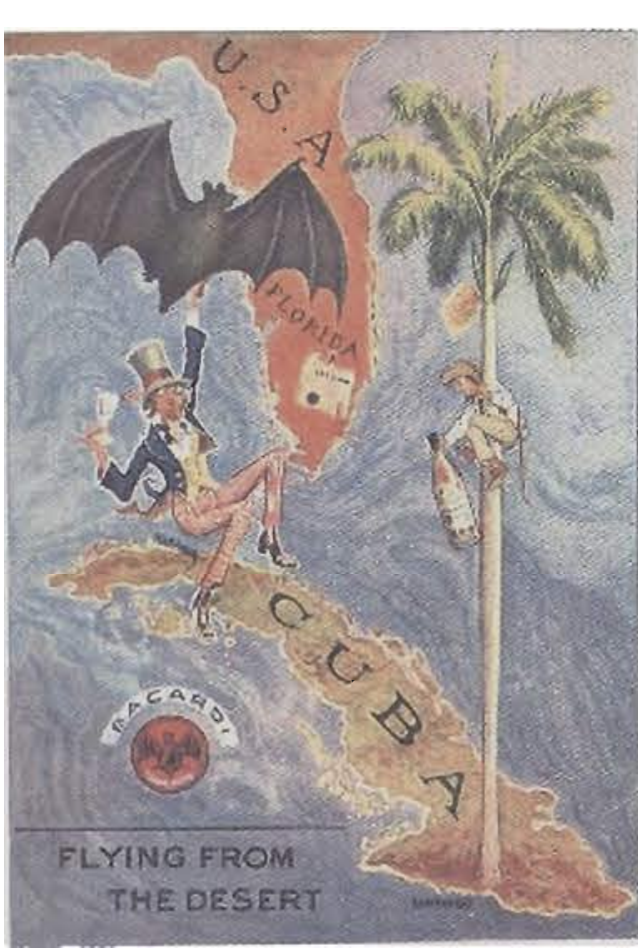

Figure 2. 1930 Postcard

President Gerardo Machado took office in 1925. Both Cuba and the United States welcomed Machado's supposedly democratic government. President Machado encouraged and guaranteed American investments on the island. ${ }^{14}$ According to Francis $\mathrm{J}$. Sicius, in 1930 President Machado launched a great promotion of Cuba in Miami in the form of a weekly report of Cuba in the Miami Herald. The reports did not contain information about business opportunities and tourism. ${ }^{15}$ A 1930's advertisement by Cuba's Bacardi Rum Company (figure 2) is indicative of Cuba's close trade with South Florida. In the poster, Uncle Sam is being flown from Cuba to Miami by a bat, which is the logo of Bacardi Rum. This is particularly poignant, since this advertisement was produced during the age of Prohibition in the United States. Illegal Bacardi Rum was smuggled into Florida by way of the canals of Coral Gables. ${ }^{16}$

advertisement of Bacardi Rum.

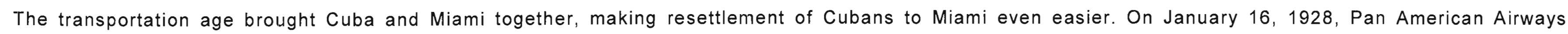

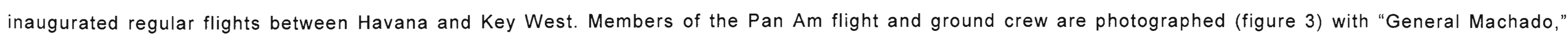

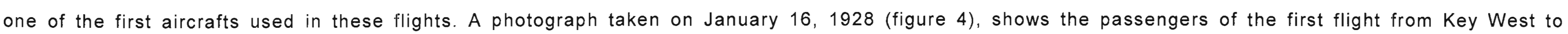




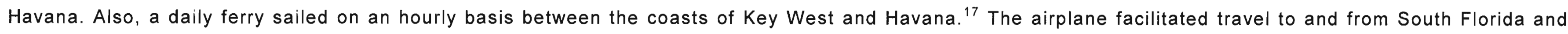
Cuba. This activity increased the commerce and trade between the two nations.

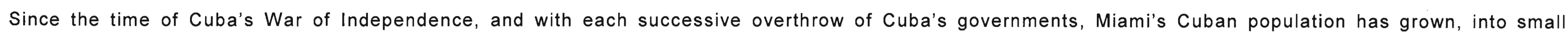

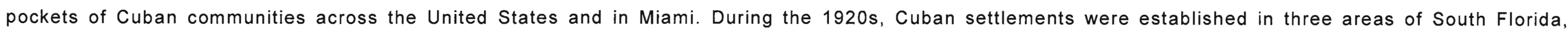

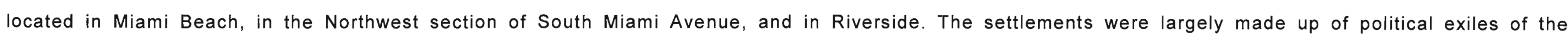

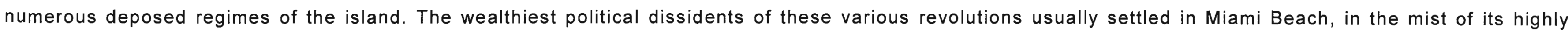
developed retail culture.

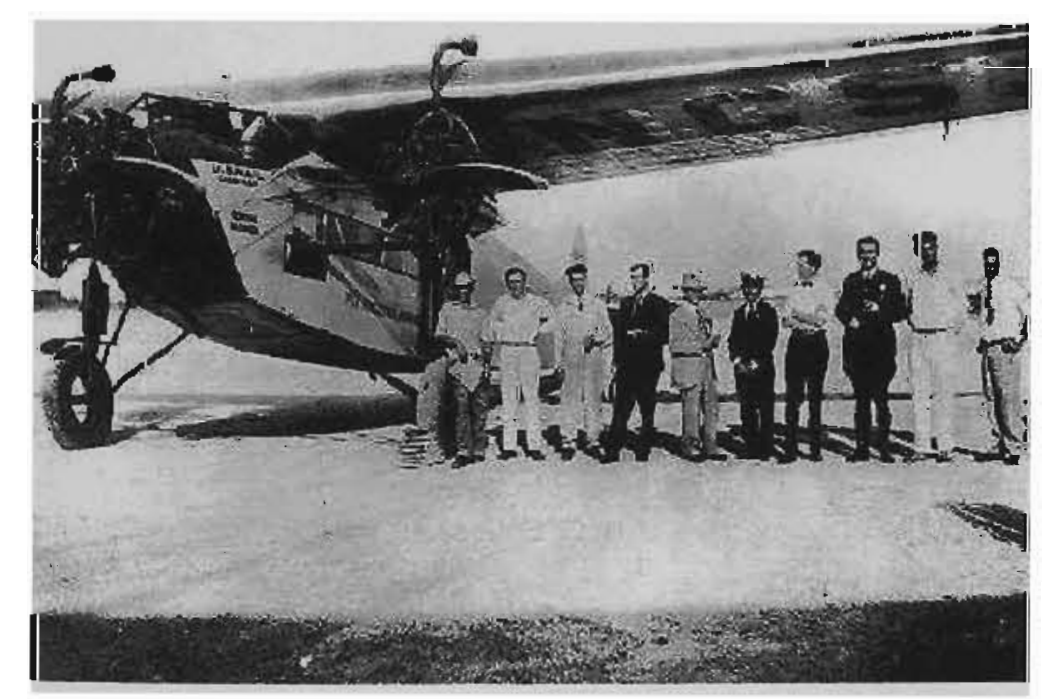

Figure 3. An October 27, 1927 photo of Pan Am's first crew of the "General Machado."

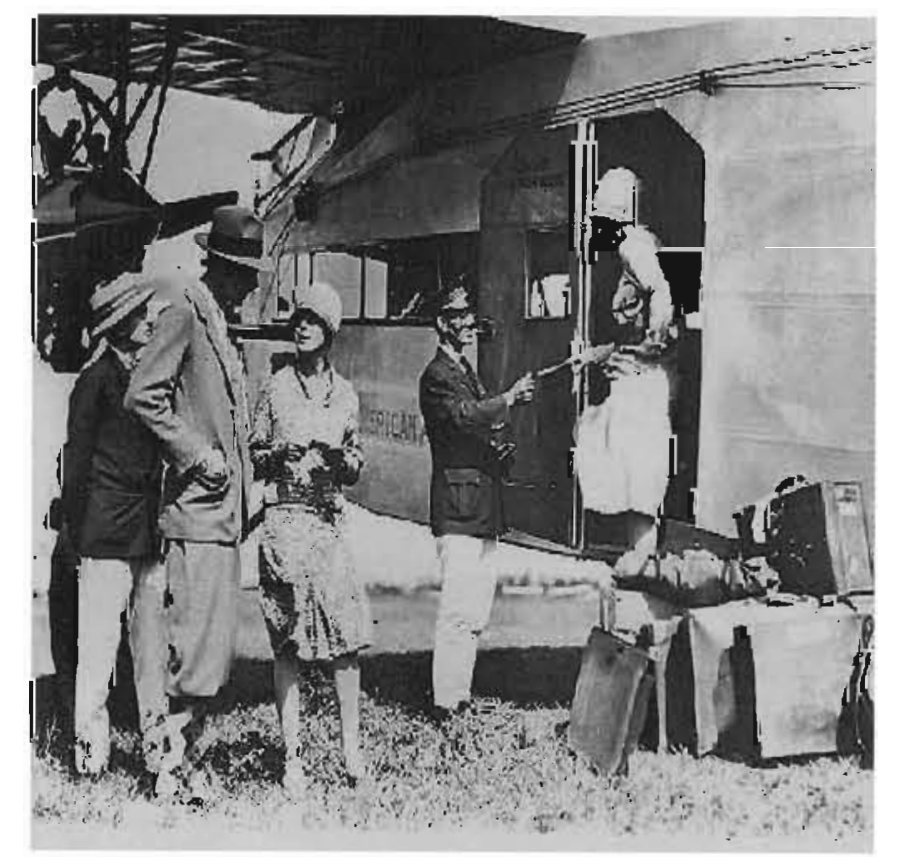

Figure 4. Pan Am's first flight from Key West to Havana.

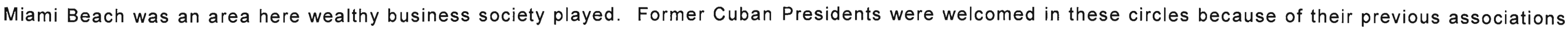

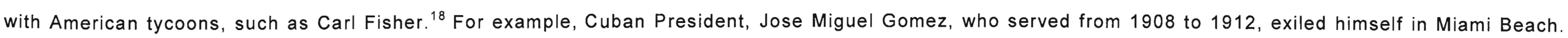

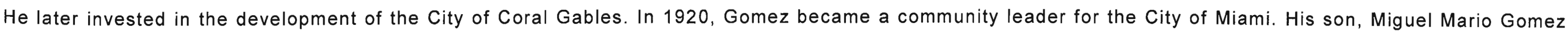




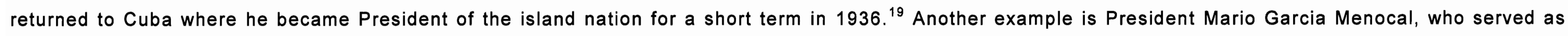
Cuba's president from 1912 to 1920 . Menocal and his followers formed a small community around his stone mansion on Collins Avenue and Lincoln Road. ${ }^{20}$

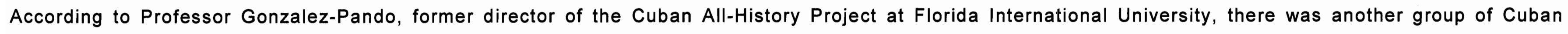

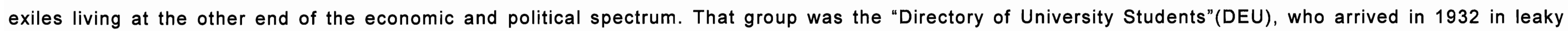

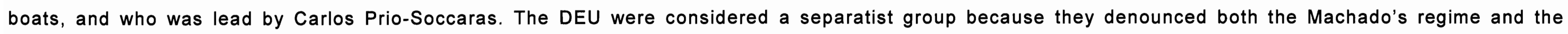

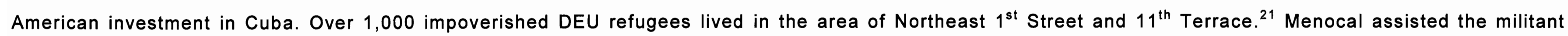

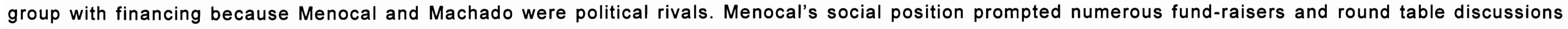

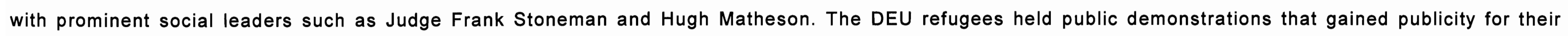

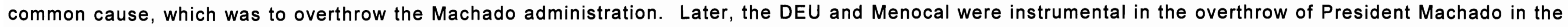
summer of $1933 .^{22}$

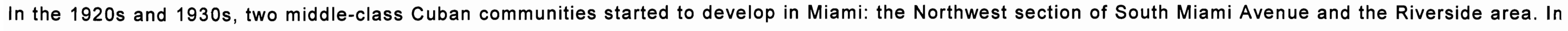

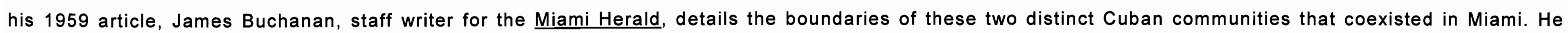

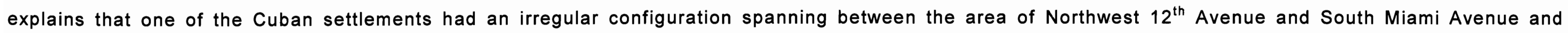

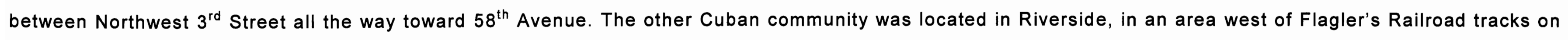

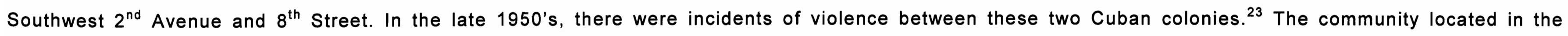

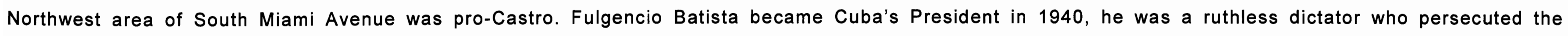

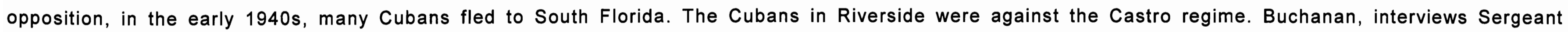

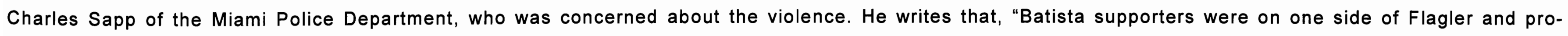

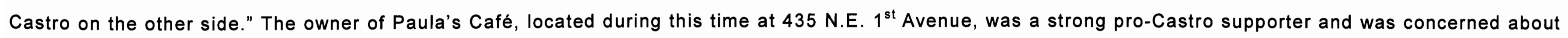
the violence between these two Cuban settlements. ${ }^{24}$ 
The Cuban area located near Miami's Northwest $12^{\text {th }}$ Avenue and $3^{\text {rd }}$ Street flourished from the 1920 s until its decline in the mid 1950 s. Terry Johnson King, staff writer for the Miami Herald, explains in her 1969 article, that by 1928 the first Cuban grocery store, "The Cuban Market," was opened at 1116 N.W. $3^{\text {rd }}$ Avenue, followed by other stores located in nearby areas. These businesses served a small community of middle-class Cubans. King points out in her article that the Cubans made their homes adjacent to the wide boulevards of South Miami Avenue, which were reminiscent of Havana's residential development of Miramar. ${ }^{25}$ The first Cuban consulate, established in the 1930s, was located in a small Spanish Baroque style residence at 5829 North Miami Avenue, (figure 5). The 1930 consulate building officially marked the establishment of this small Cuban community.
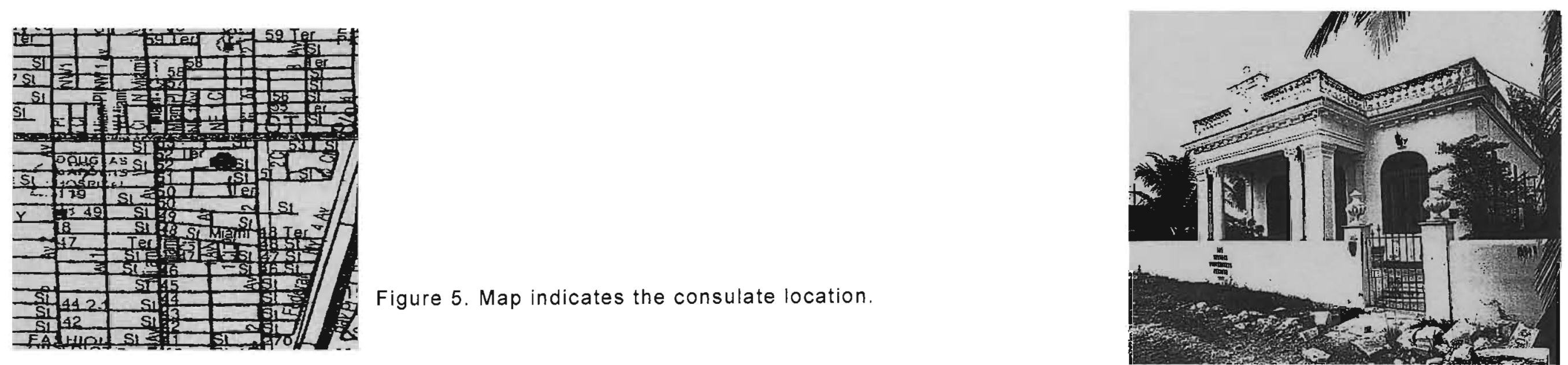

Figure 6. 1930 Cuban Consulate

The Cuban Consulate was a typical Cuban house, according to Jose Casanova, planner with the City of Miami. Polished Cuban tile floors, dark wood trim and arched windows of colored glass above the doors were all typical elements found in Cuban residential architecture. Staff writer for The Miami Herald, lan Glass, describes the 1929 consulate building in his 1972 article. He notes that the walls were constructed of yellow bricks imported from Cuba and which were stuccoed and painted white. ${ }^{26}$ The front façade (figure 6 ) has the typical ample Cuban porch and the Beaux-Arts decorative details typically Cuban, of the 1930 period. ${ }^{27}$ The Cuban/French style used in the consulate can also be found in the residences along El Prado in Havana built in the late 1920's. During the Great Depression, the Cuban government moved the consulate to another location, abandoning the residence. Since that time, the house has been privately owned. Today, it still stands but the surrounding Cuban neighborhood no longer exists. ${ }^{28}$ 


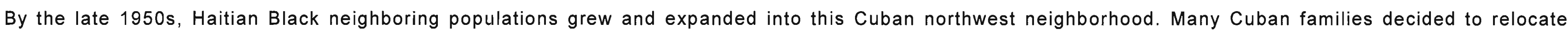

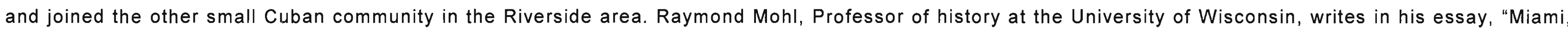

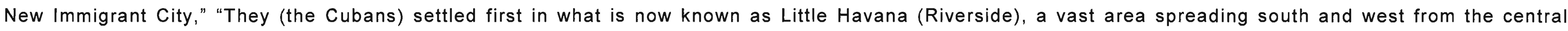

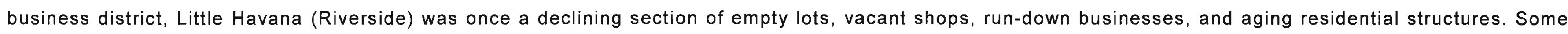

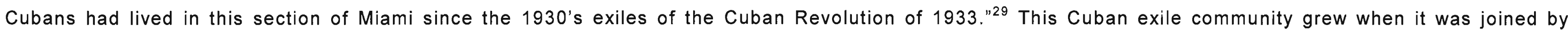

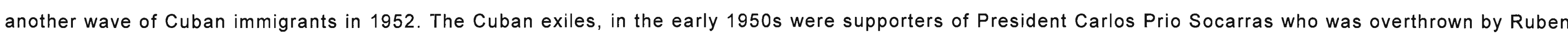

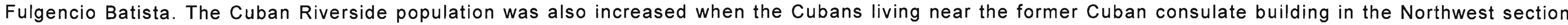

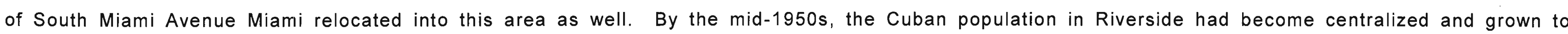
$10,000 .{ }^{30}$ A photographs taken in the 1950 s (figure 7 and 8 ), indicate the condition of $8^{\text {th }}$ Street at that time.

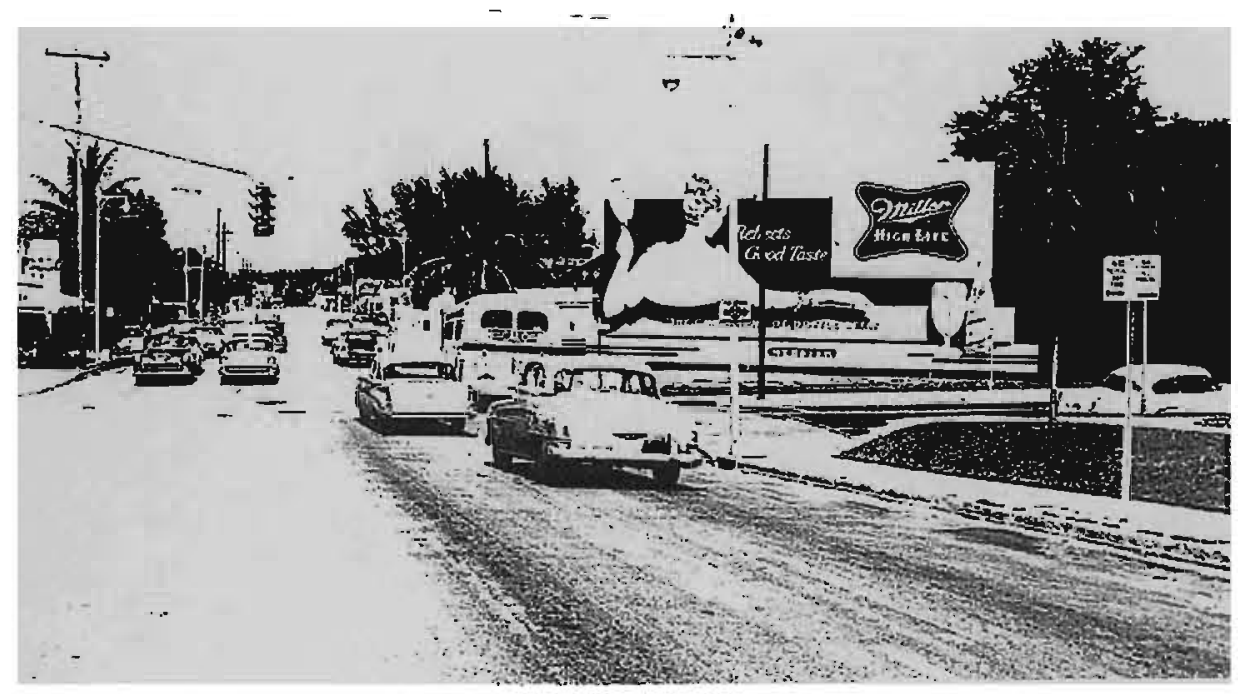

Figure 7.

Riverside, S.W. $8^{\text {TH }}$ Street $\& 2^{\text {nd }}$ Avenue in 1952. 


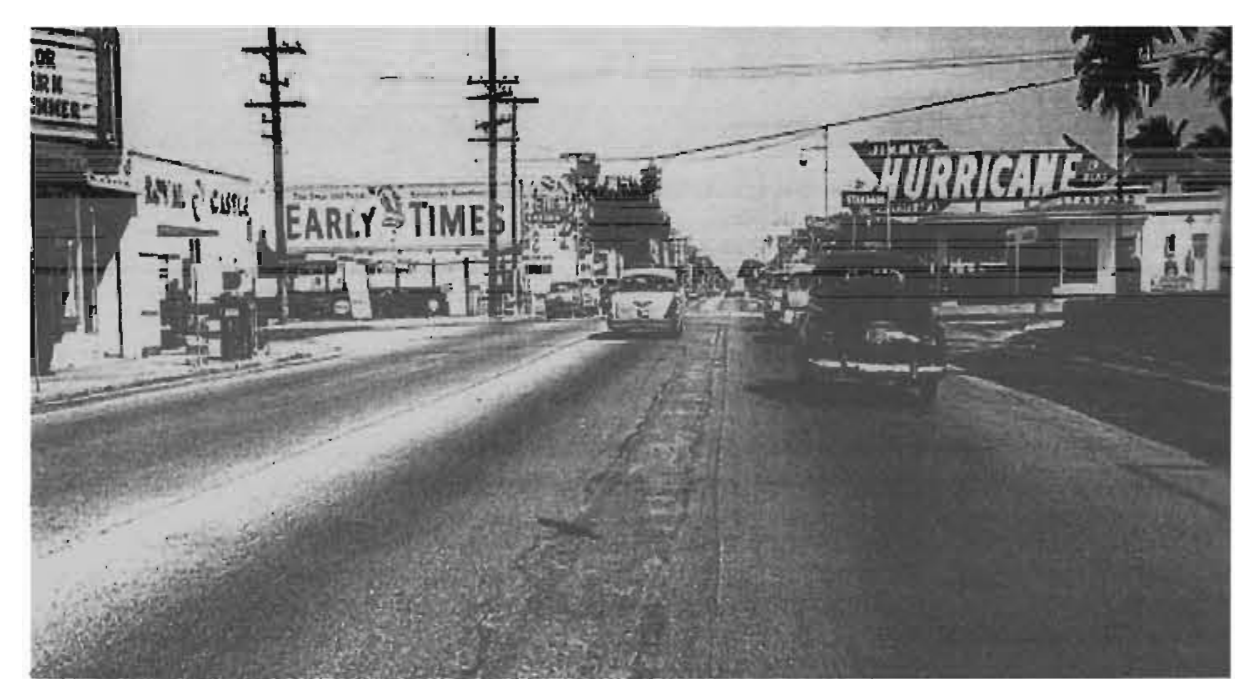

Figure 8.

Riverside, S.W. $8^{\text {TH }}$ Street

$7^{\text {th }}$ Avenue in 1952 


\section{ENDNOTES:}

1. Gonzalez-Pando, Miguel. 1998. The Cuban-Americans. Westport, Connecticut: Greenwood Press.

2. Gonzalez-Pando, Miguel. 1996. Greater Miami: Spirit of Cuban Enterprise. Fort Lauderdale: Copperfield Publication, Inc.

3. Gauld, Charles. 1971. Florida and Cuba linked together for 450 years. The Miami News, 1 May.

4. Masud-Piloto, Roberto Felix. 1998. With Open Arms. Totowa, New Jersey: Rowman and Littlefield.

5. Florida Department of Natural Resources Division of Recreation and Parks. 1985. Ybor City State Museum Brochure.

6. Bretos. 1991. Cuba and Miami. Miami: Historical Association of South Florida

7. Moore Parks, Arva. 1993. Calle Ocho: Interpretive Center Concept and Documentation. Miami, Florida: City of Miami Study.

8. Sicius, Francis J. 1998. Cubans in Miami: A Historical Perspective. Tequesta, December.

9. Moore Parks, Arva. 1993. Calle Ocho: Interpretive Center Concept and Documentation. Miami, Florida: City of Miami Study

10. Peters, Thelma. 1984. Miami 1909. Miami: Banyan Books Inc.

11. Allma N, T.D. Miami: City of the Future. 1987. New York: The Atlantic Monthly Press.

12. Sicius, Francis J. 1998. Cubans in Miami: A Historical Perspective. Tequesta, December

13. Peters, Thelma. 1984. Miami 1909. Miami: Banyan Books Inc.

14. Levine, Robert and Asis, Moises. 2000. Cuban Miami. New Brusnswick: Rutgers University Press.

15. Sicius, Francis J. 1998. Cubans in Miami: A Historical Perspective. Tequesta, December

16. Peters, Thelma. 1984. Miami 1909. Miami: Banyan Books Inc

17. Ibid

18. Levine, Robert and Asis, Moises. 2000. Cuban Miami. New Brusnswick: Rutgers University Press.

19. Presidents of Cuba. 2000. Carnegie Mellon University, Lycos Inc. http:/l www.angelfire.com 
20. Gonzalez-Pando, Miguel. 1998. The Cuban-Americans. Westport, Connecticut: Greenwood Press.

21. Ibid.

22. Presidents of Cuba. 2000. Carnegie Mellon University, Lycos Inc. http:// www.angelfire.com.

23. Bucchanan, James. 1959. Miami Casablanca of the Carribean? The Miami Herald, 20 July.

24. Ibid.

25. Johnson King, Terry. 1969. Little Havana Develops Spread-and Its Not from the Middle Ages. The Miami Herald, 14 April.

26. Glass, Ian. 1975. Knock, Knock Who's There at Villa Paula? The Miami Herald, 31 October.

27. Carley, Rachel. 1997. Cuba 400 years of Architectural Heritage. New York, NY: Whitney Library of Design an imprint of Watson Guptill Publication.

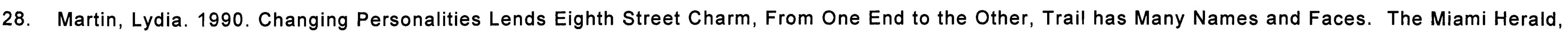
16 August.

29. Mohl, Raymond. 1990. Searching for the Sunbelt: Historical Perspective on a Region. Knoxville: The University of Tennessee Press.

30. Ibid. 


\section{CHAPTER 2:}

\section{EARLY HISTORY OF $8^{\text {TH }}$ STREET AND RIVERSIDE}

The area of Riverside has a history dating back to its original settlers: the Tequesta Indians. Their settlements were staggered along the banks of the Miami River. Today's Jose Marti Park was the site of a Tequesta Indian camp dating back to 400 AD. The site along the Miami River was excavated in $1982 .{ }^{1}$ Dr. Paul George, local historian and professor, confirms that pottery, projectile points and a woman's grave were uncovered at this site. By the eighteen-century, thousands of Tequesta Indians had either died in battle or as a result of the diseases of chicken pox and measles that were brought into the area by Europeans. Dr. Paul George describes the last major activity of the Tequesta Indians in Florida. He writes, "They (the Tequesta) petitioned the Spanish government to dispatch vessels to South Florida and enable them to move to Cuba and nearby areas. They felt Miami was too perilous." ${ }^{2}$ The Spaniards send only a few ships; not to transport them all. The Tequesta who reached Cuba soon found themselves enslaved by the Spaniards.

On April $15^{\text {th }}, 1896$, Henry Flagler's railroad entered Miami. This event changed the course of Miami's history forever. On July $28^{\text {th }}, 1896$, Miami became incorporated. Arva Moore Parks, describes the area in 1896. She writes, "When the city of Miami was incorporated in 1896, the area now known as Little Havana was nothing more than a 'broken cowpath' and a sprawling wilderness populated by pines and palmettos. ${ }^{3}$ A photograph taken in 1896 (figure 10 ), reveals the natural wilderness on $8^{\text {th }}$ Street. Dr Paul George, comments on the population growth of Miami's early years. He writes, "Miami's population had ratcheted from a handful of settlers, who lived primarily along the river in 1895, to several hundred persons by the summer in 1896 . Miami continued to grow quickly, despite some early setbacks. The city's population jumped past 1,660 in $1900,5,400$ in $1910 .{ }^{44}$ 


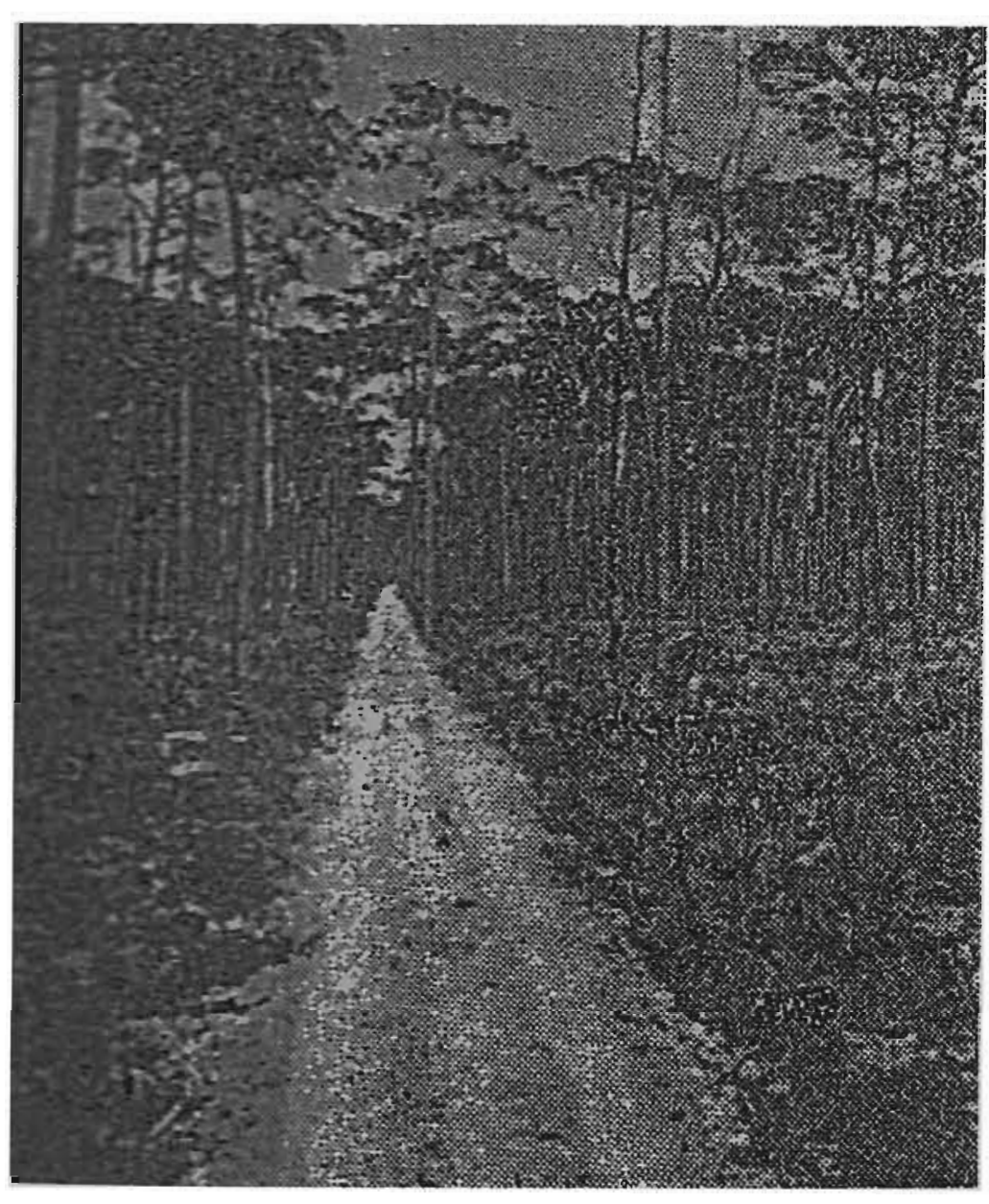

Figure 10. $8^{\text {th }}$ Street west of $2^{\text {nd }}$ Avenue In 1896.

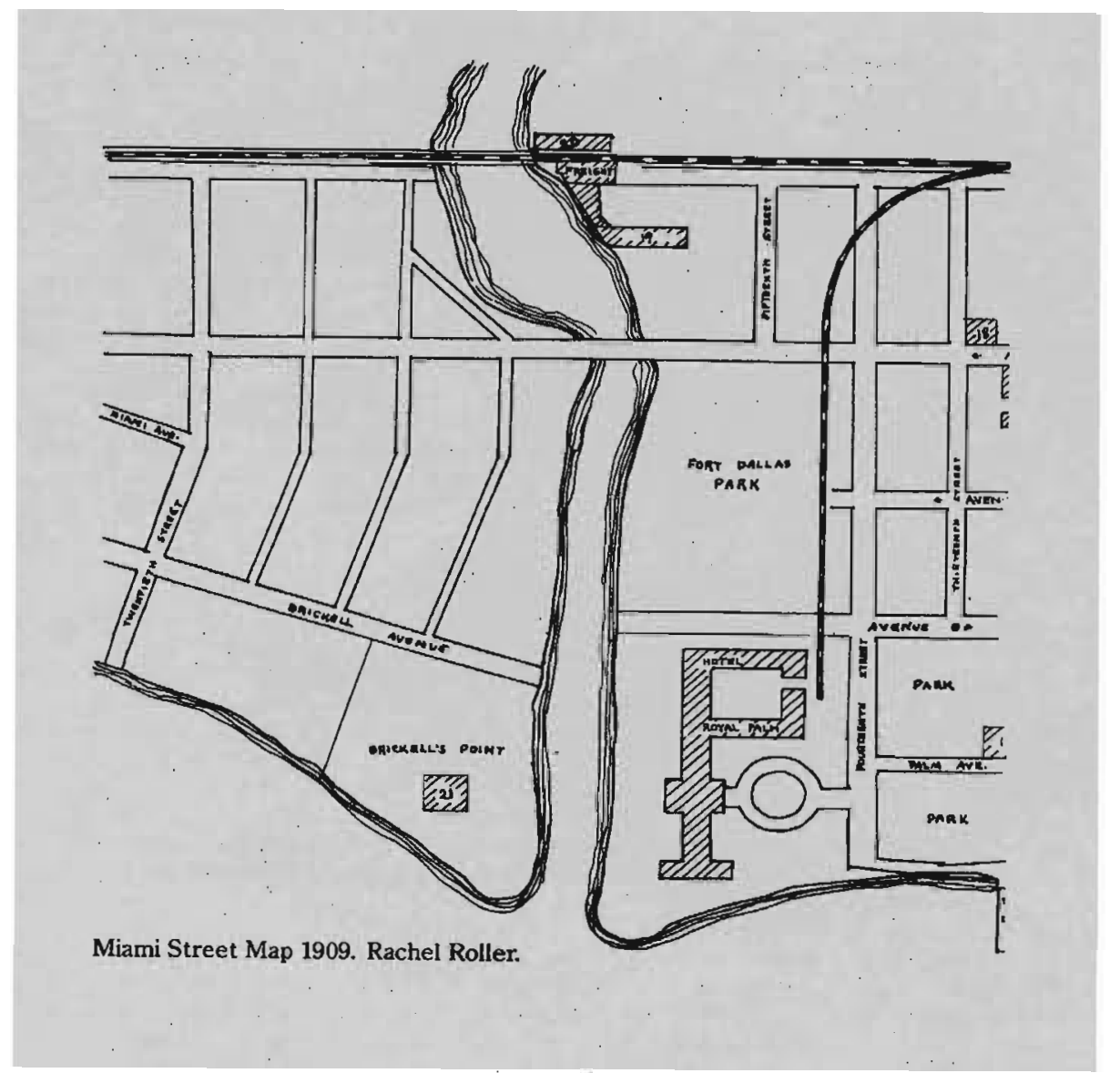

Figure 11. Map Flagler's map of Miami in 1909 .

Flagler planned the railroad to pass through the City of Miami. A map of Miami dating back to 1909 (figure 11 ) indicates the railroad tracks along $2^{\text {nd }}$ Avenue. At that time, $8^{\text {th }}$ Street was called $20^{\text {th }}$ Street. A photograph taken at this time (figure 12), indicates the residential development east of the $2^{\text {nd }}$ Avenue border. On $20^{\text {th }}$ Street $\left(8^{\text {th }}\right.$ Street today) west of $2^{\text {nd }}$ Avenue, the area was scattered with Seminole Indian camps (figure 13 ) and settlements of Black Bahamian families. ${ }^{5}$ In this photograph some pioneers can be seen along with the Seminole Indians indicating their somewhat peaceful coexistence. Lydia Martin, staff writer for The Miami Herald explains in 1999 that two "shotgun" homes dating back to the 1900 s still stand on $8^{\text {th }}$ Street and $5^{\text {th }}$ Avenue. The few Black families in the area occupied these homes in the early 1900 s. $^{6}$ 


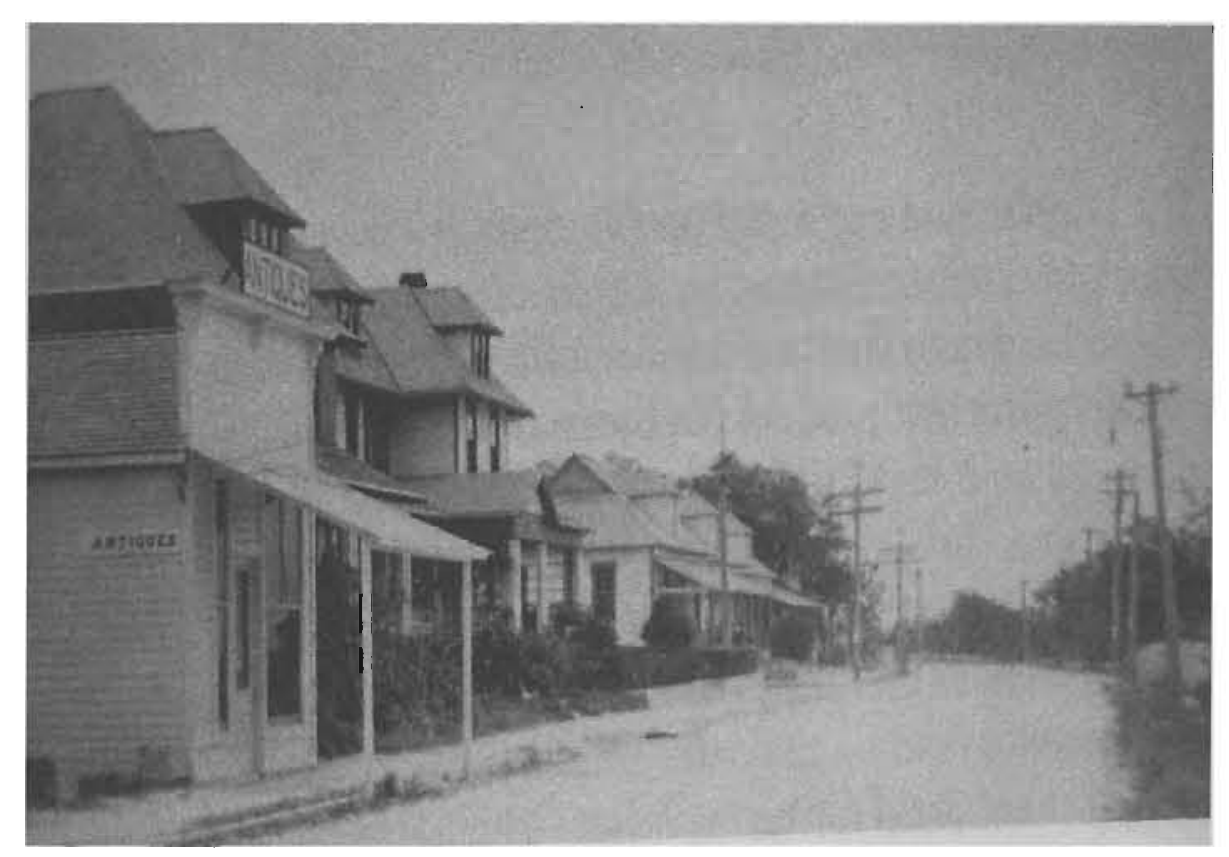

Figure 12. Development east of $2^{\text {nd }}$ Avenue

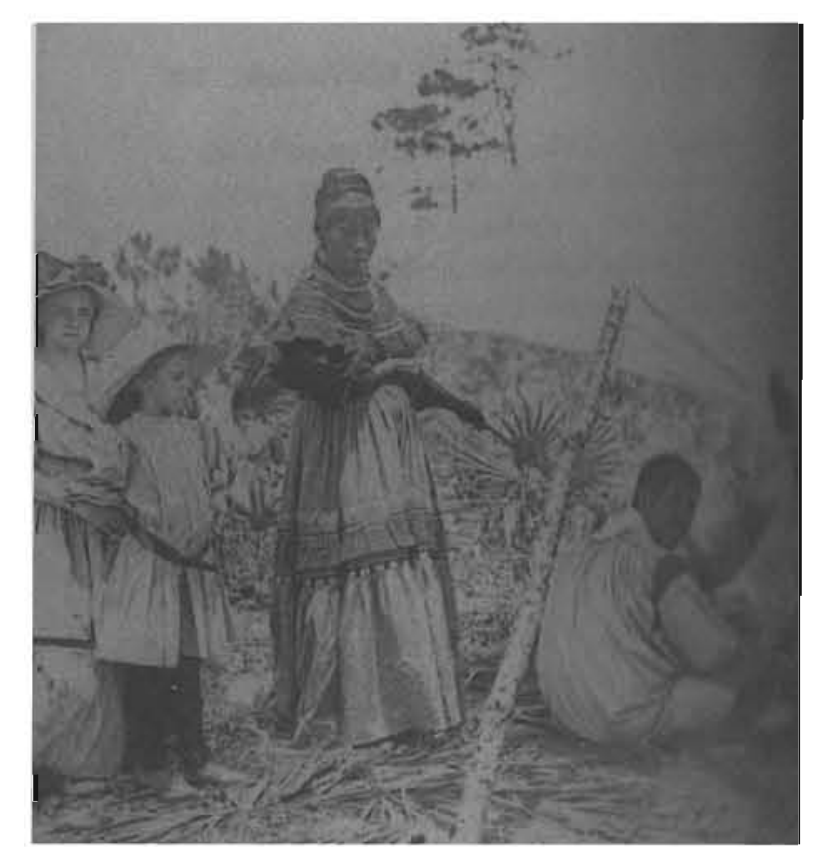

Figure 13. Indian Camps west of SW $2^{\text {nd }}$ Avenue

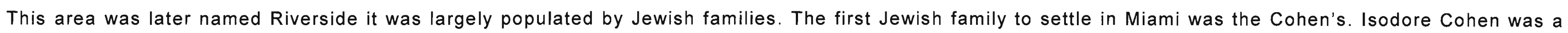

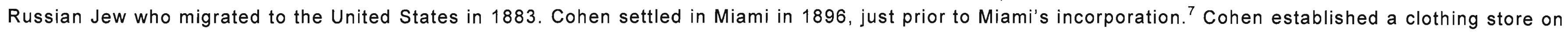

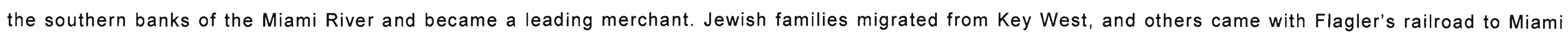

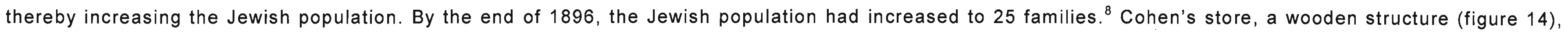

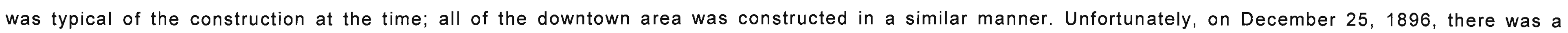

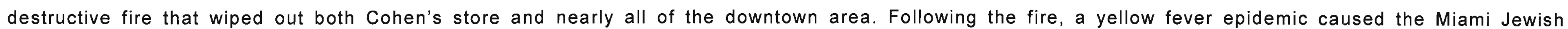

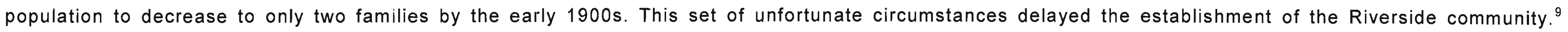

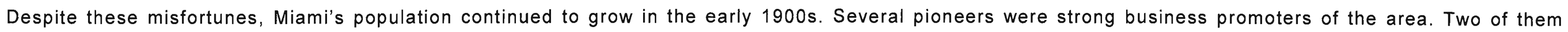
were, General Samuel Lawrence and Samuel A. Belcher who owned large homesteads in the Riverside area. 

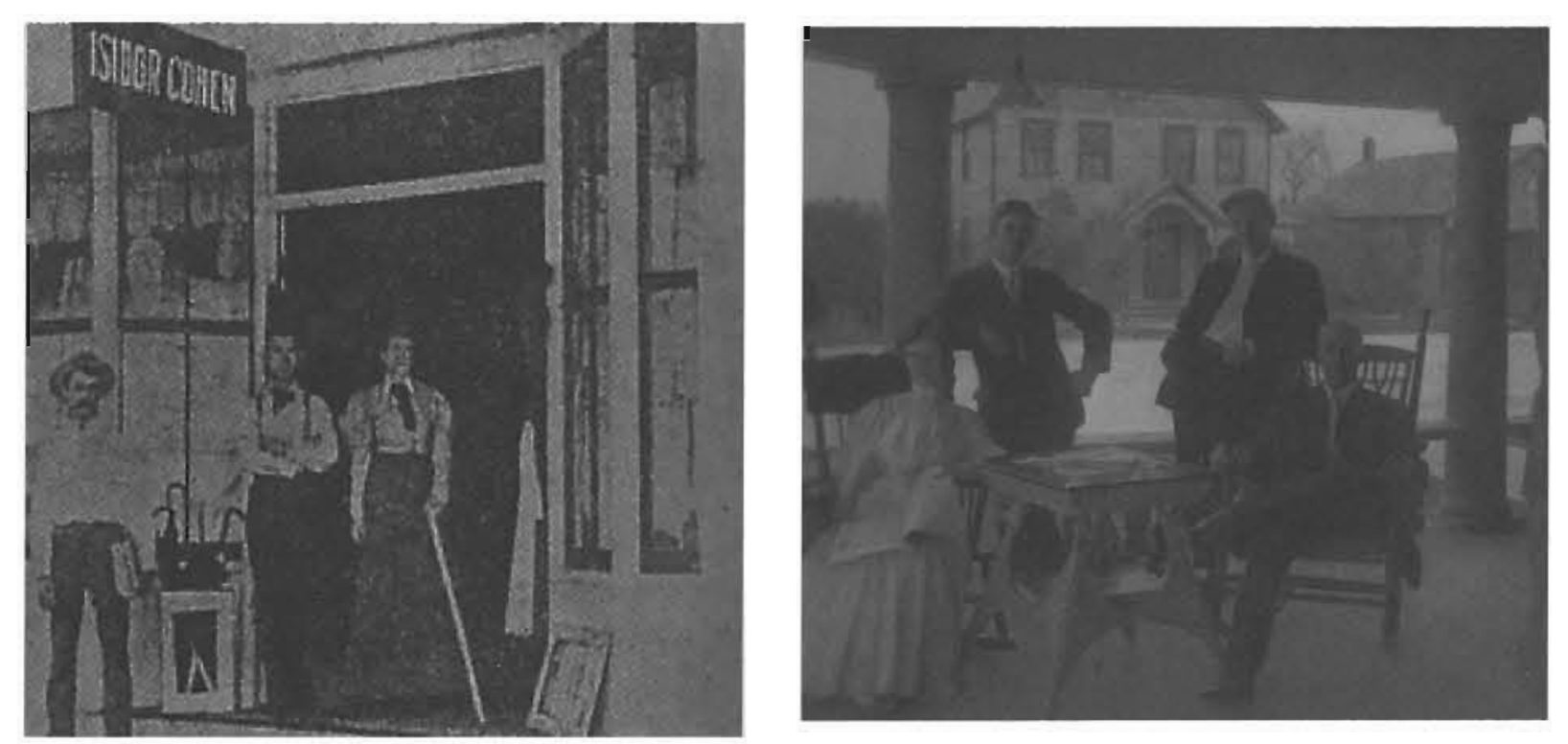

Figure 14. Isodore Cohen's store.

Figure 15. Samuel Belcher and his family in their home.

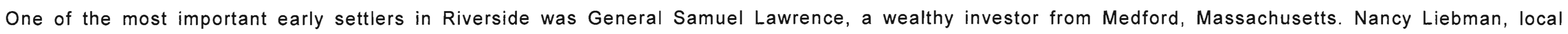

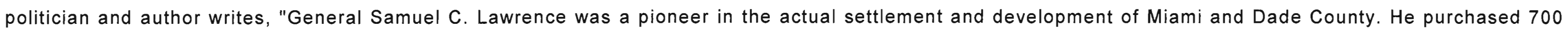

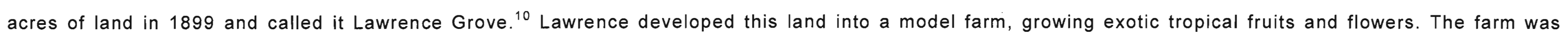

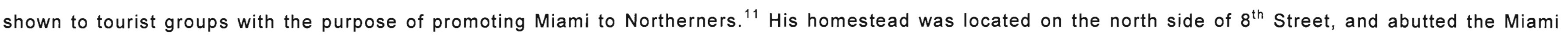
River between $13^{\text {th }}$ Avenue and $19^{\text {th }}$ Avenue. After his death in 1911 , the land was sold and then platted into residential lots. ${ }^{12}$

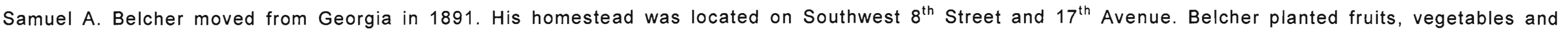

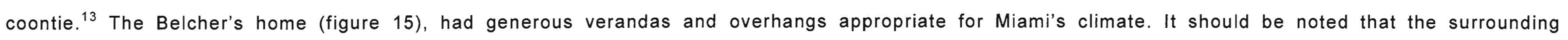

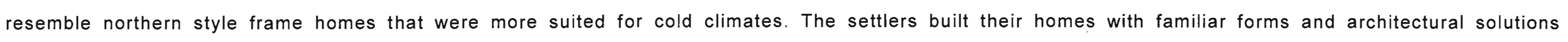

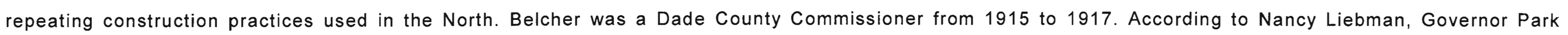
Tramell appointed Samuel Belcher to the Central Highway Association. This association adopted the Tamiami Trail as a project in $1915 .{ }^{14}$ 


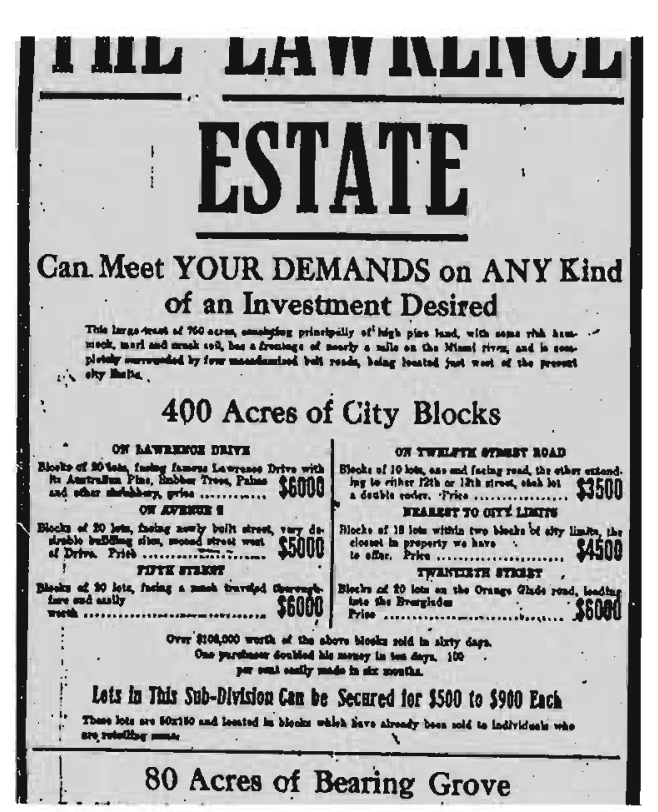

Figure 16. Lawrence Estate Auction February 18, 1913.

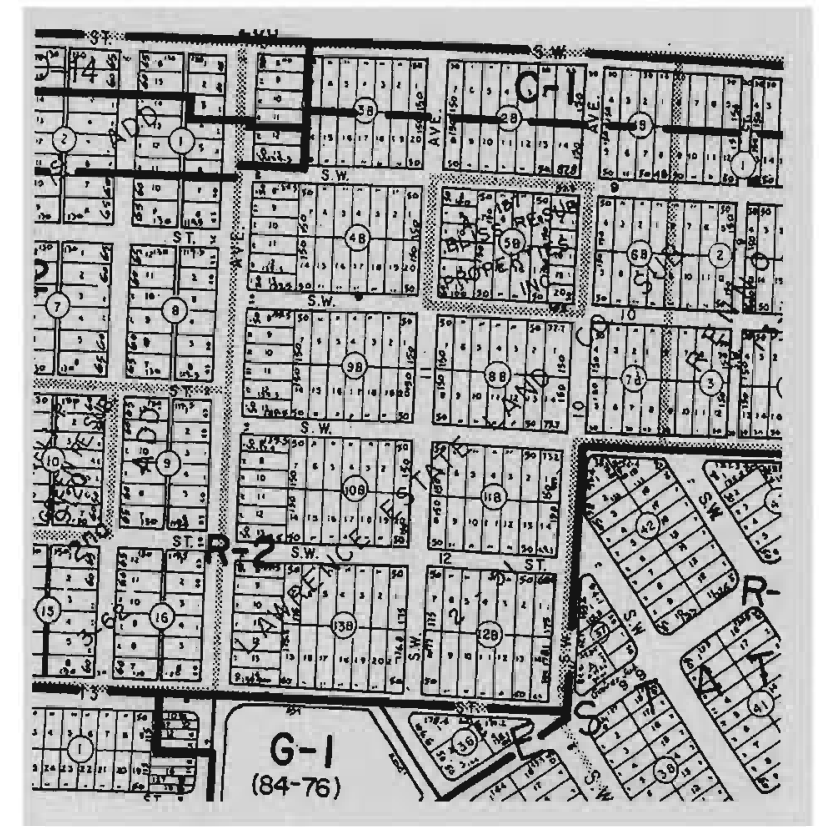

Figure 17. Lawrence Estate Plot plan.

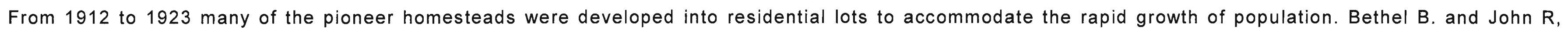

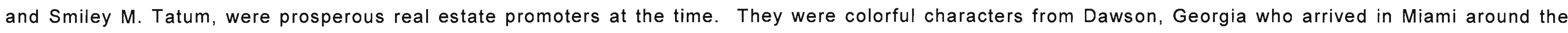

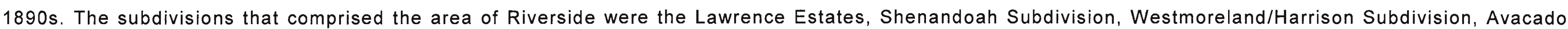
Park Subdivision, and Manleys Resubdivision. ${ }^{15}$

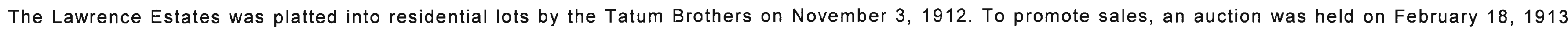

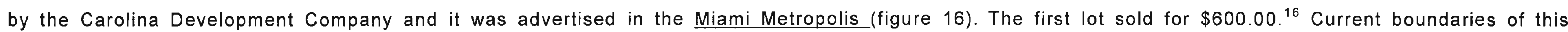

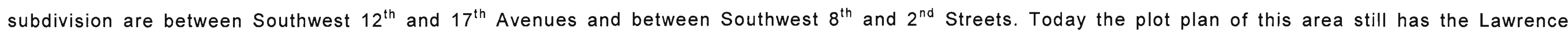
Estate name (figure 17). ${ }^{17}$

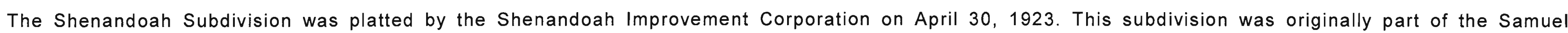
Belcher homestead. Its current boundaries are irregular: it is located in the vicinity of Southwest $14^{\text {th }}$ and $17^{\text {th }}$ Avenues and between $8^{\text {th }}$ and $14^{\text {th }}$ Streets. ${ }^{18}$ 


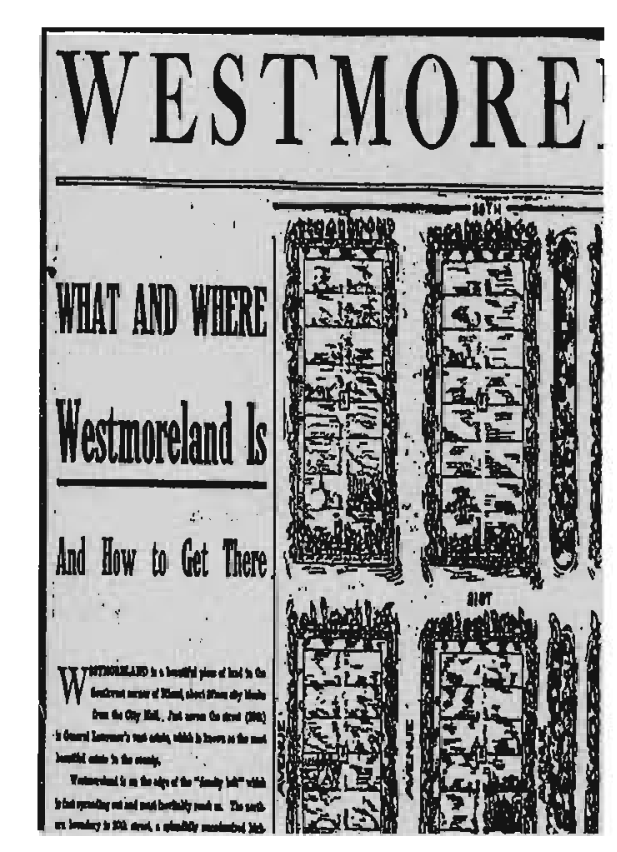

Figure 18. Westmooreland Auction Announcement.

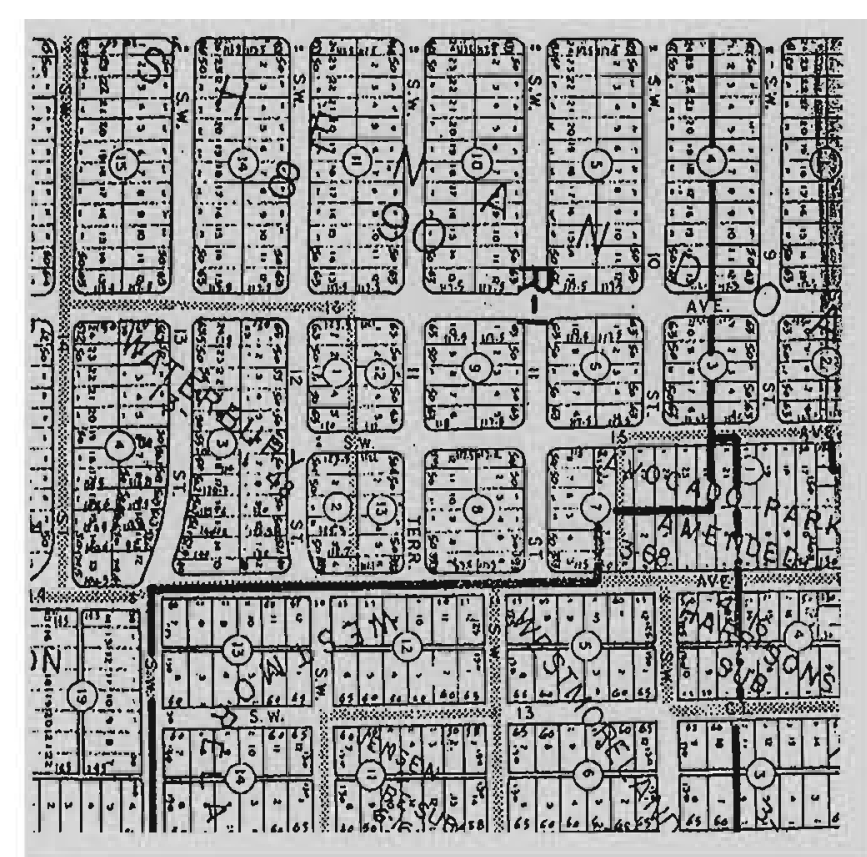

Figure 19. Plot plan showing subdivision.

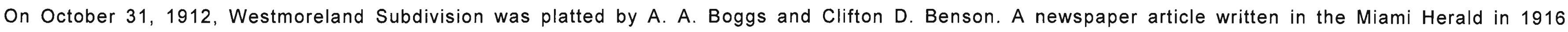

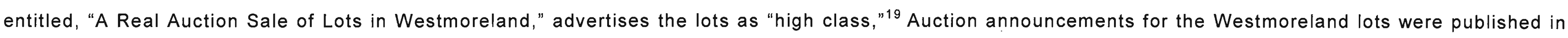

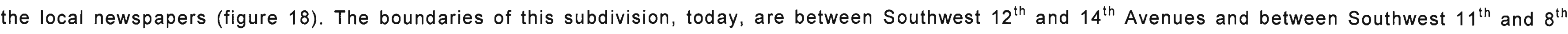

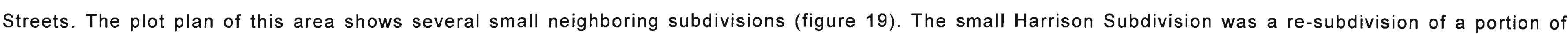
the larger Westmoreland Subdivision. Its current boundaries are between Southwest $10^{\text {th }}$ Street to $13^{\text {th }}$ Court and between Southwest $8^{\text {th }}$ and $10^{\text {th }}$ Streets. ${ }^{20}$

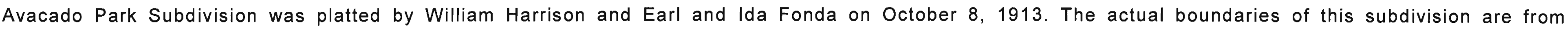

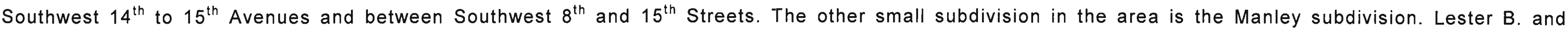

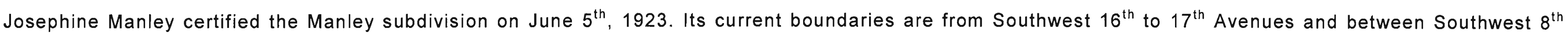
and $7^{\text {th }}$ Streets. ${ }^{21}$ 


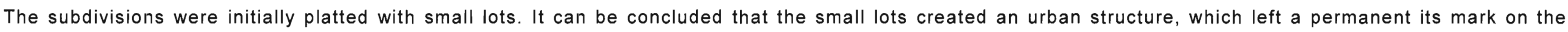
area. The scale of the lots made the area affordable. In the future, many immigrant groups often settled in this area.

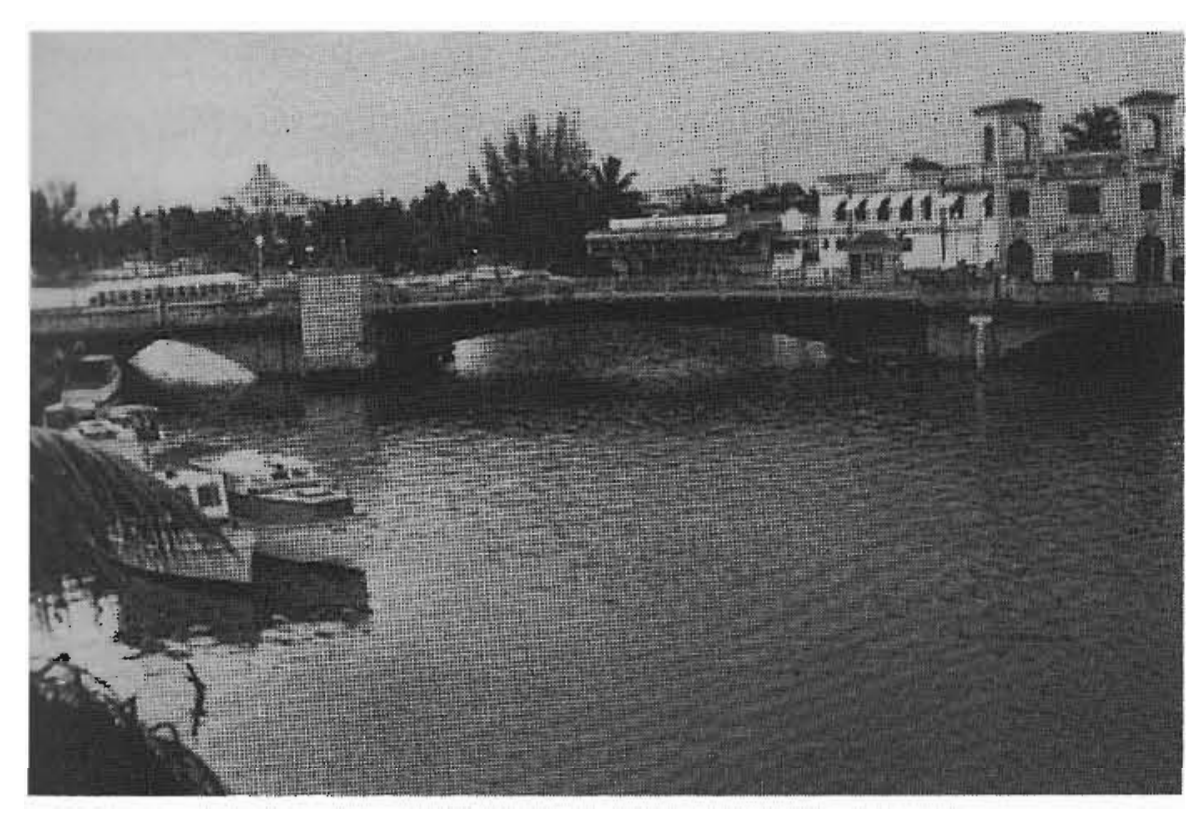

Figure 20. Flagler Bridge 1950.

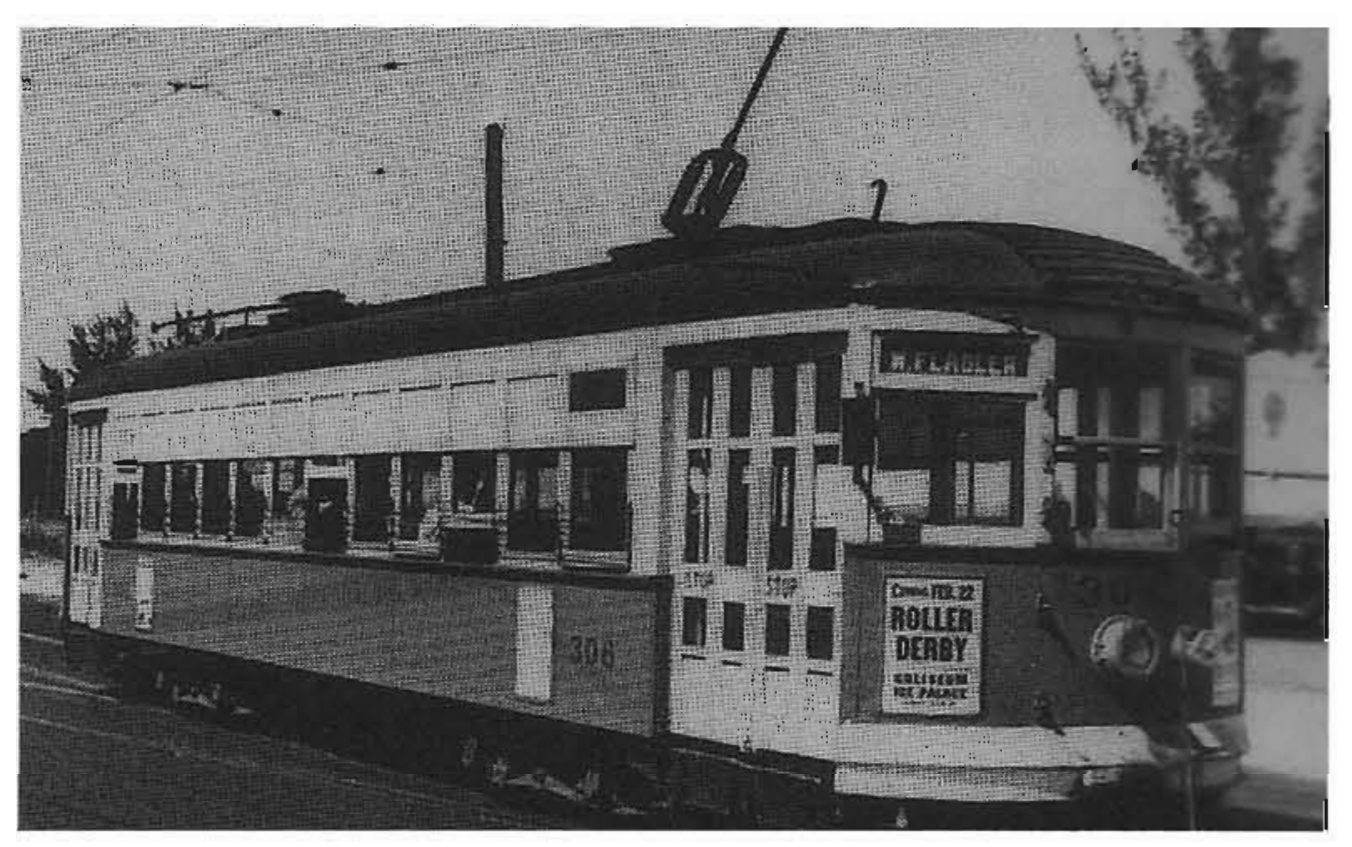

Figure 21. Trolley on Flagler \& 22 Avenue.

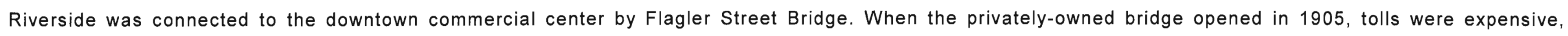

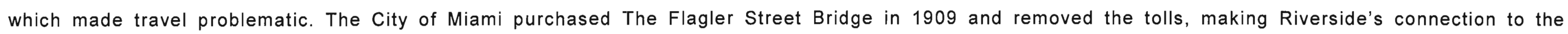

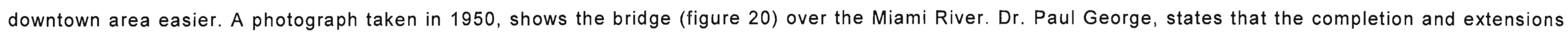

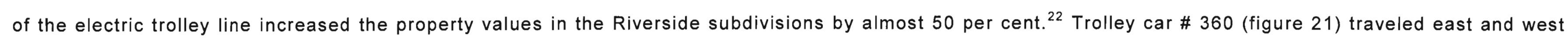

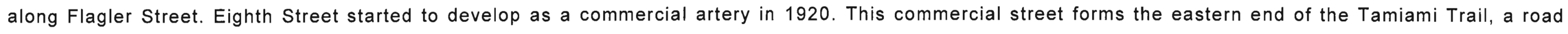
that connects the east and west coasts of Florida. 


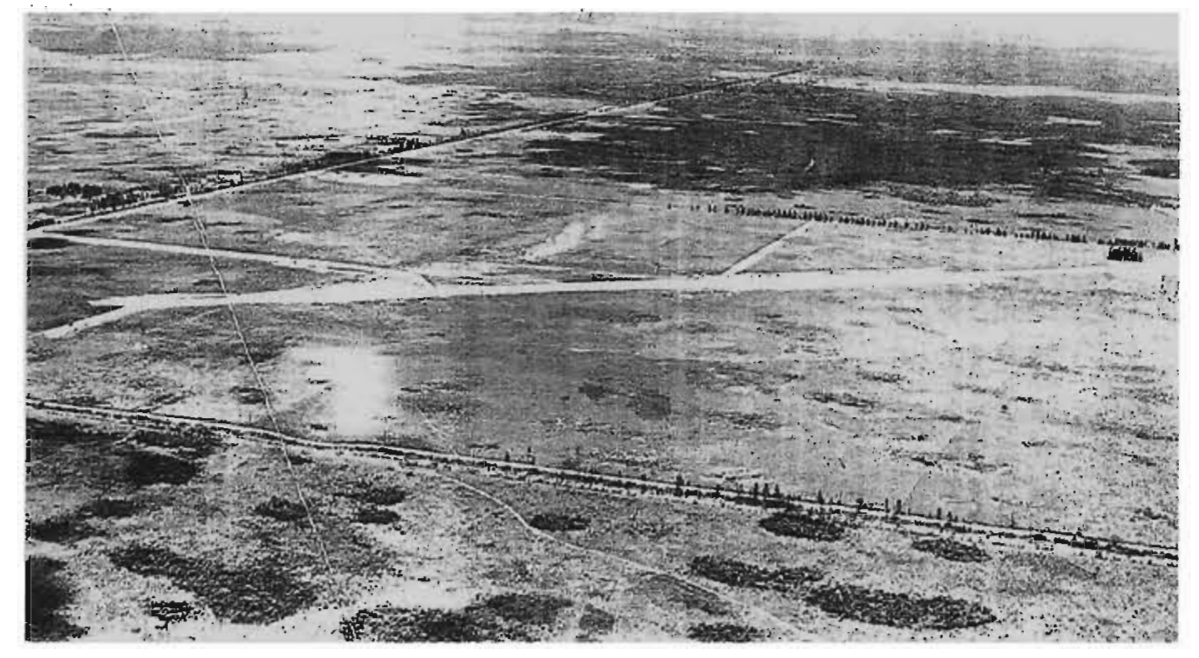

Figure 22. Tamiami Trail, 1950

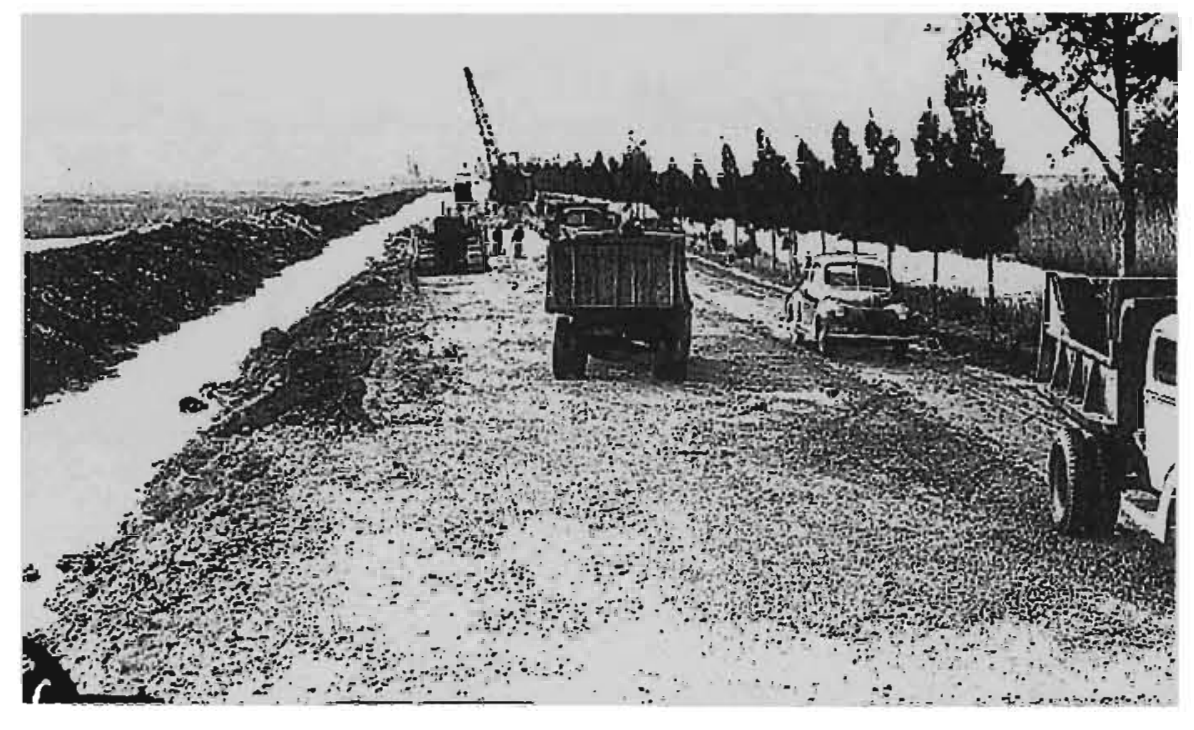

Figure 23. Tamiami Trail April $4^{\text {th }} 1951$.

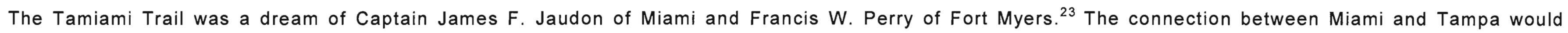

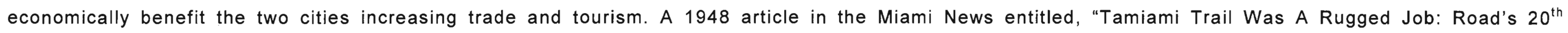

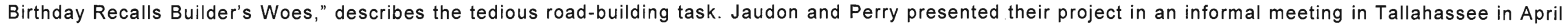

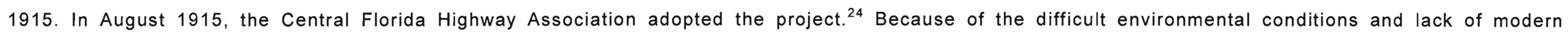

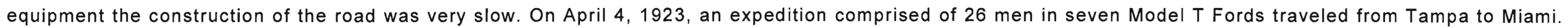

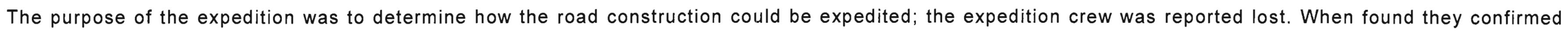

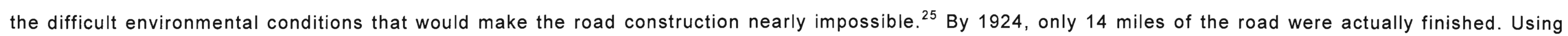

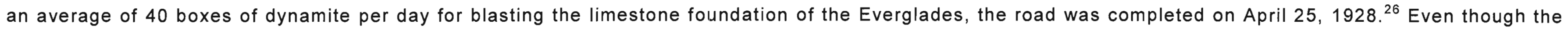

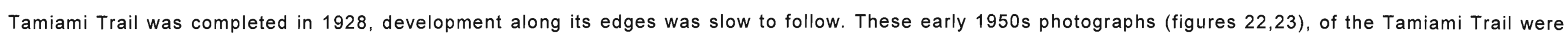

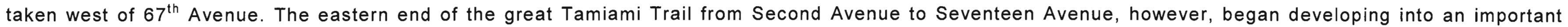

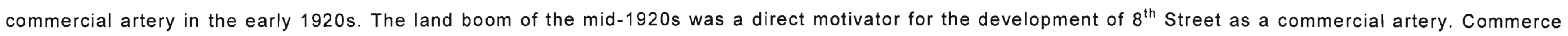
on Eighth Street served the surrounding residential neighborhoods. ${ }^{27}$ 


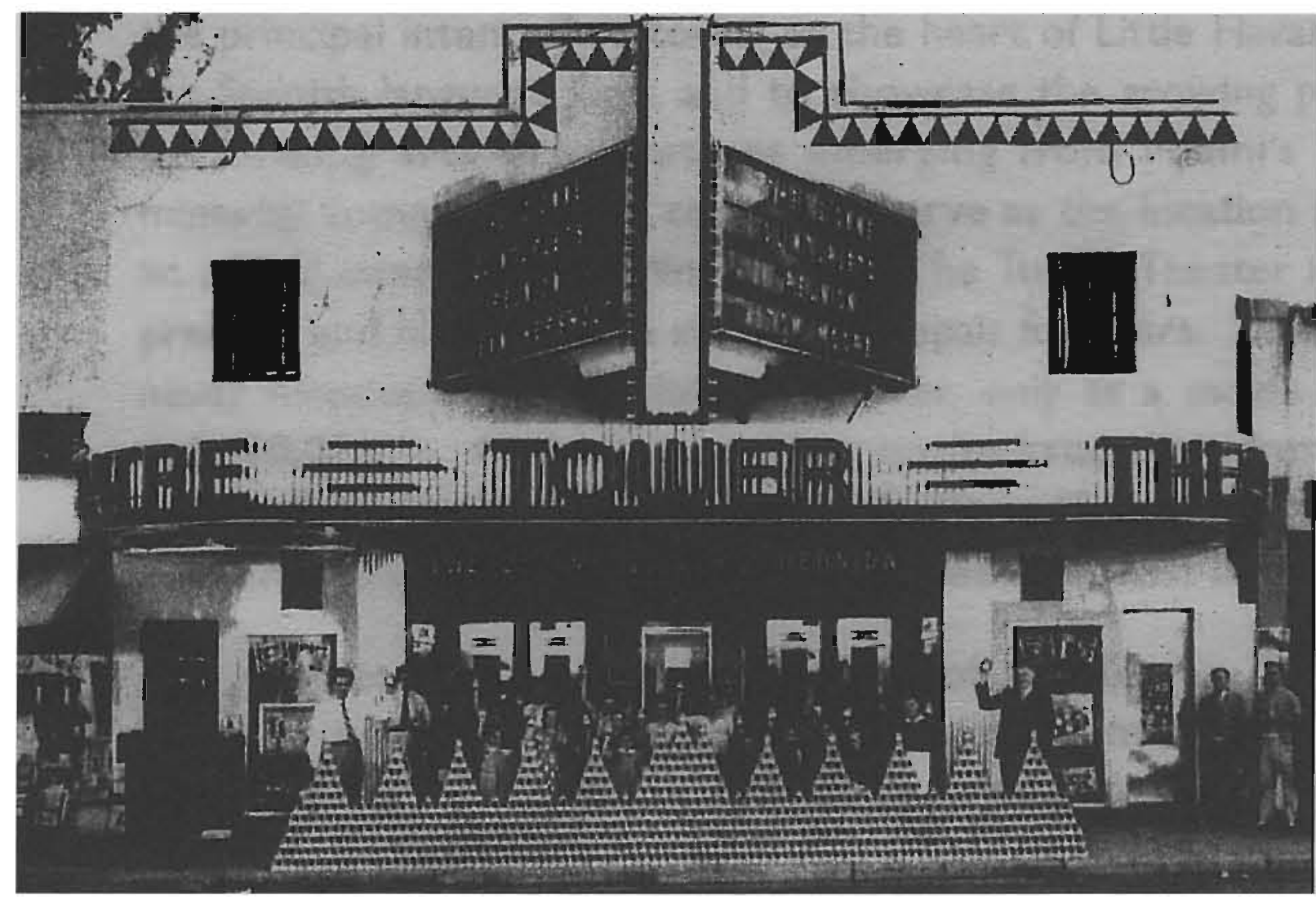

Figure 24. Tower Theater before remodeling in 1931.

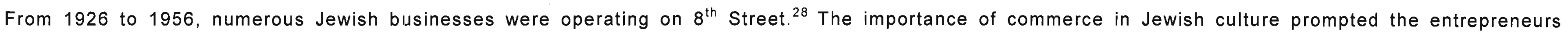

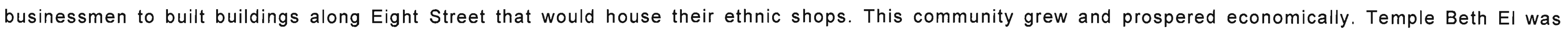

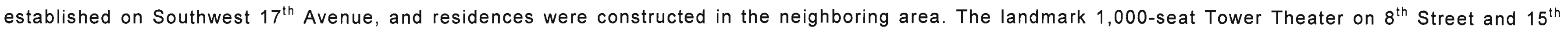

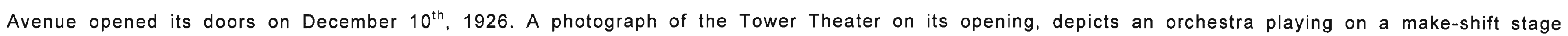

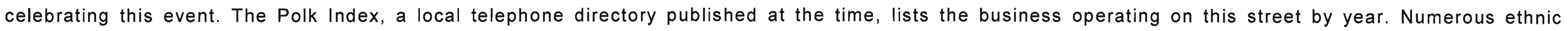

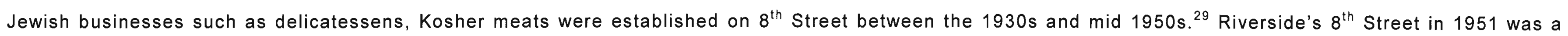

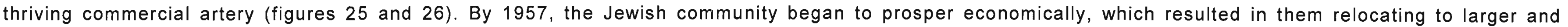
newer homes in other Miami suburbs such as Westchester and South Kendall. ${ }^{30}$ 


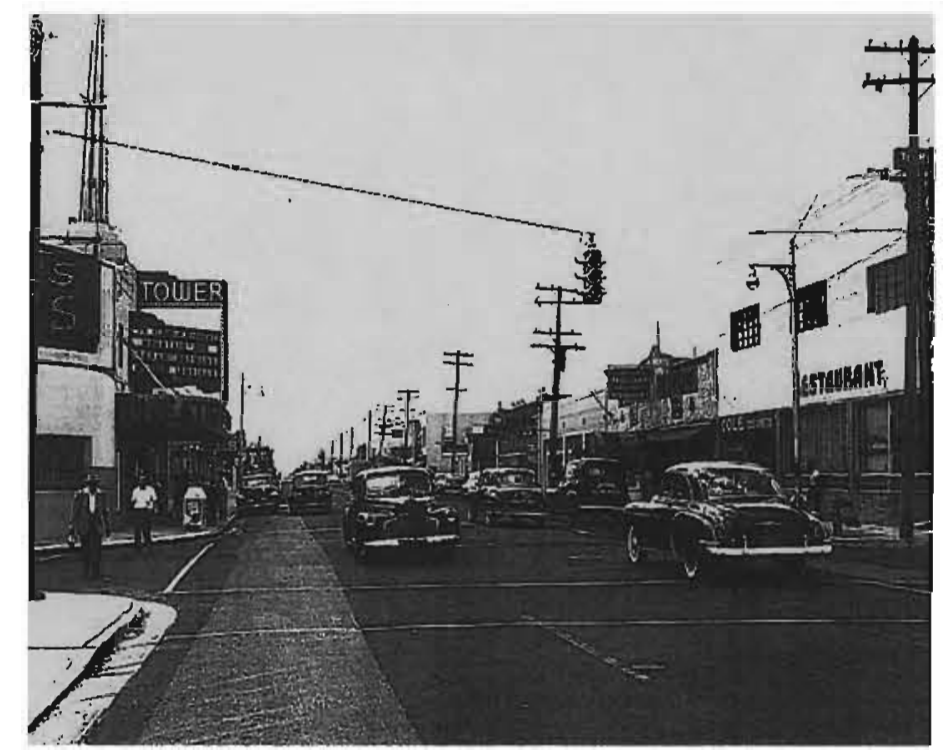

Figure 25. 1951 Riverside $8^{\text {th }}$ Street \& $15^{\text {th }}$ Avenue.

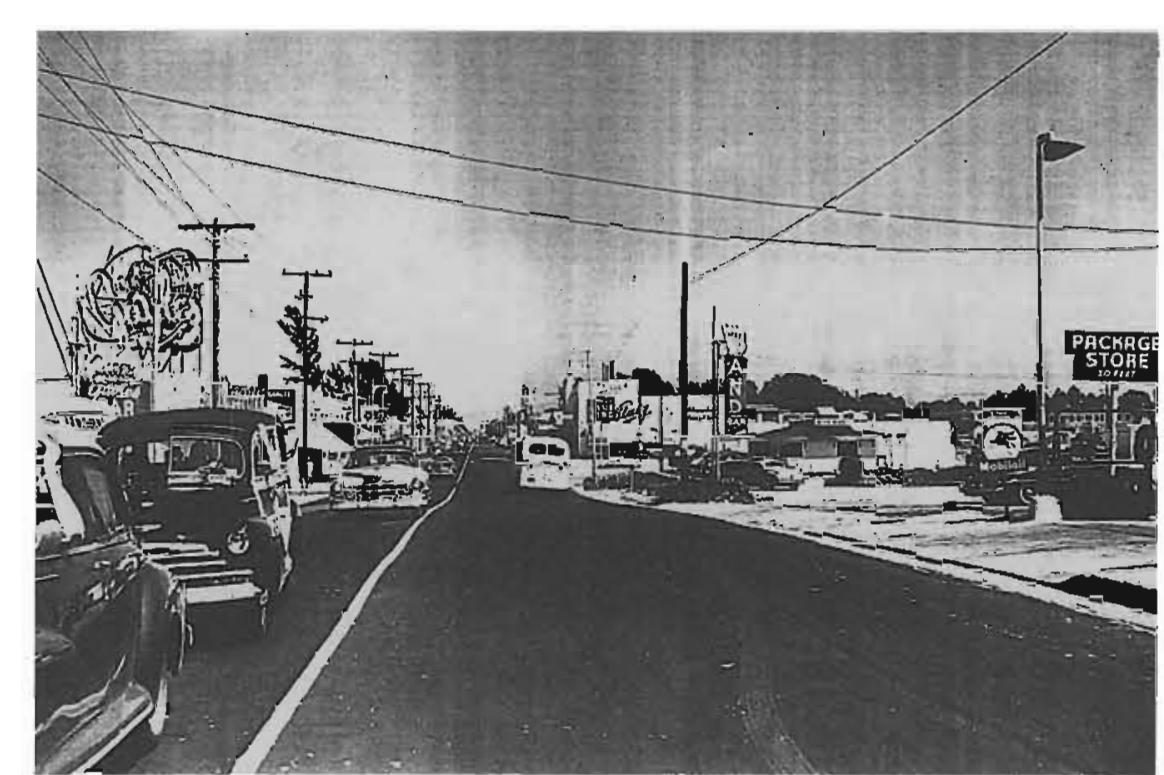

Figure 26. 1951 Riverside \& 32 Avenue.

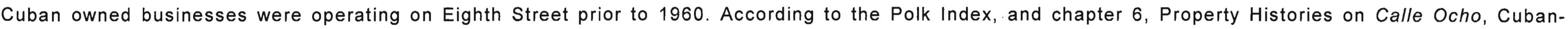

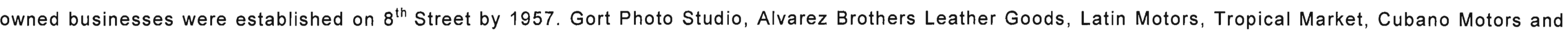
the Madrid Restaurant were the Cuban-owned establishments that began to prosper in this area. ${ }^{31}$

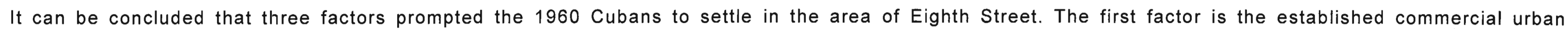

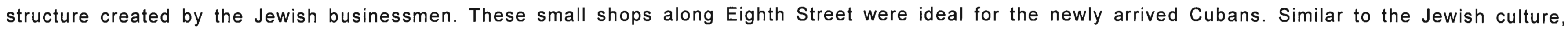

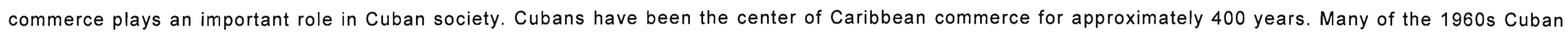

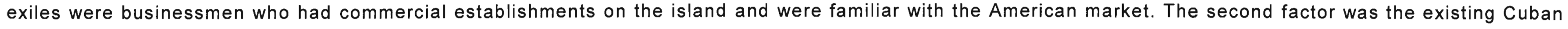

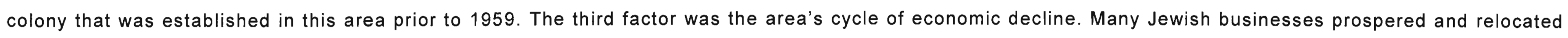
to more prestigious addresses and some fled due to the large Cuban influx to the area. This produced affordable real estate. ${ }^{32}$ 


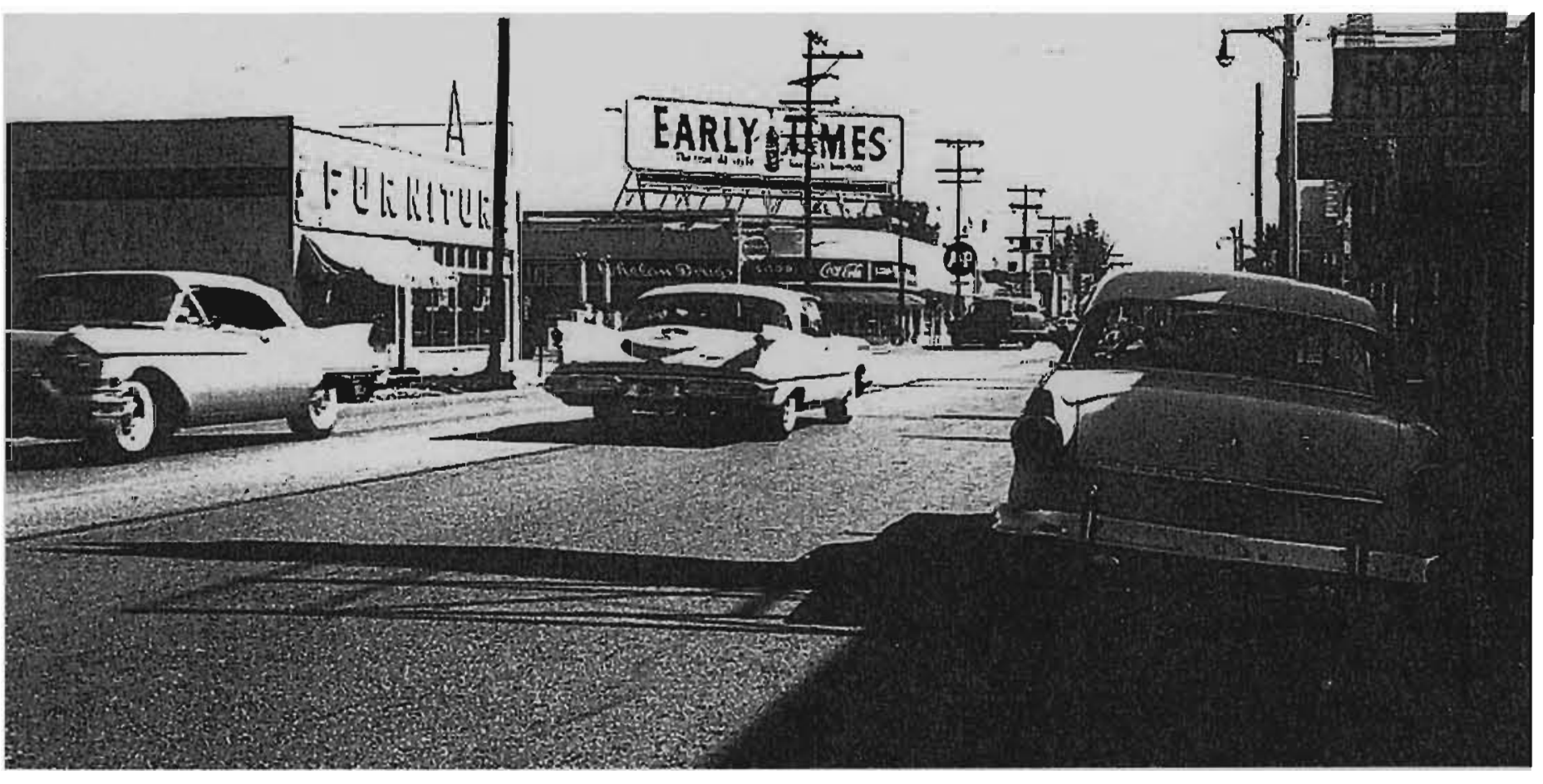

Figure 27. $8^{T H}$ Street $\& 22$ Avenue in September, 1961. 


\section{ENDNOTES:}

1 Martin, Lydia. 1990. A Stroll through Little Havana's History. The Miami Herald, 1 November.

2. George, Dr. Paul. 1991. The Dr. Paul George Walking Tour of East Little Havana. Miami: The Historic Association of Southern Florida.

3. Moore Parks, Arva. 1993. Calle Ocho: Interpretive Center Concept and Documentation. Miami, Florida: City of Miami.

4. George, Dr. Paul. 1991. The Dr. Paul George Walking Tour of East Little Havana. Miami: The Historic Association of Southern Florida.

5. Peters, Thelma. 1984. Miami 1909. Miami: Banyan Books Inc.

6. Martin, Lydia. 1990. A Stroll through Little Havana's History. The Miami Herald, 1 November.

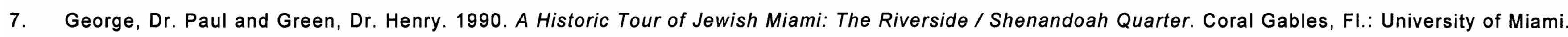

8. Liebman, Nancy. 1993. Calle Ocho Historic District Concept and Documentation, Miami, Florida: City of Miami.

9. Peters, Thelma. 1984. Miami 1909. Miami: Banyan Books Inc.

10. Liebman, Nancy. 1993. Calle Ocho Historic District Concept and Documentation, Miami, Florida: City of Miami.

11. Ibid

12. Crowd Attends Auction Sale of Lawrence Lots. 1913. Miami Daily News. 18 February.

13. Peters, Thelma. 1984. Miami 1909. Miami: Banyan Books Inc.

14. Liebman, Nancy. 1993. Calle Ocho Historic District Concept and Documentation, Miami, Florida: City of Miami.

15. Chuckrow, Chuck. 1948. Tamiami Trail Sales Section: Merchants to Hold a 3-Day Sales Event on Tamiami Trail, The Miami News 25 April.

16. Opportunity Knocks Once. 1913. Miami Metropolis, 18 February.

17. Liebman, Nancy. 1993. Calle Ocho Historic District Concept and Documentation, Miami, Florida: City of Miami.

18. Ibid.

19. A Real Auction Sale of Lots in Westmoreland. 1916. The Miami Herald, 26 March.

20. Liebman, Nancy. 1993. Calle Ocho Historic District Concept and Documentation, Miami, Florida: City of Miami. 
21. Ibid.

22. George, Dr. Paul. 1991. The Dr. Paul George Walking Tour of East Little Havana. Miami: The Historic Association of Southern Florida.

23. Dyches, June Jolley. 19 .How Florida Blazed a Trail: Pioneer Builders Overcame Odds to Link East to West. The Miami News, 15 June.

24. Chuckrow, Chuck. 1948. Tamiami Trail Was Rugged Job: Road 's $20^{\text {th }}$ Birthday Recalls Woes. The Miami News, 25 April.

25. Who Remembers Lost Caravan Which Once Spanned Glades? 1954. The Miami Herald, 26 September.

26. Stone, Maria. 1979. Tamiami Trail: A collection of Stories. Naples: Butterfly Press Stone Enterprises Inc.

27. George, Dr. Paul and Green, Dr. Henry. 1990. A Historic Tour of Jewish Miami: The Riverside / Shenandoah Quarter. Coral Gables, Fl.: University of Miami.

28. Ibid.

29. Florida's Polk Directory. 1959. Miami, Florida: R.L. Polk \& Co. Publishers.

30. George, Dr. Paul and Green, Dr. Henry. 1990. A Historic Tour of Jewish Miami: The Riverside / Shenandoah Quarter. Coral Gables, Fl.: University of Miami.

31. Florida's Polk Directory. 1960. Miami, Florida: R.L. Polk \& Co. Publishers.

32. George, Dr. Paul. 1991. The Dr. Paul George Walking Tour of East Little Havana. Miami: The Historic Association of Southern Florida. 


\section{CHAPTER 3:}

\section{CUBAN MIGRATION 1960 TO 1973}

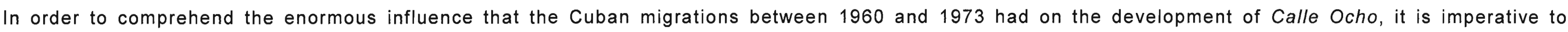

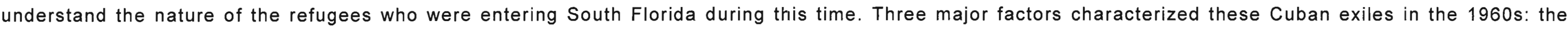

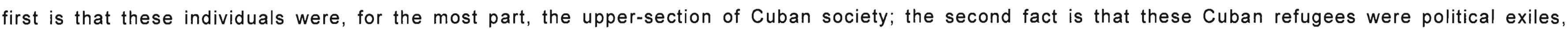
stripped of all their material possessions; and the third is their vast numbers.

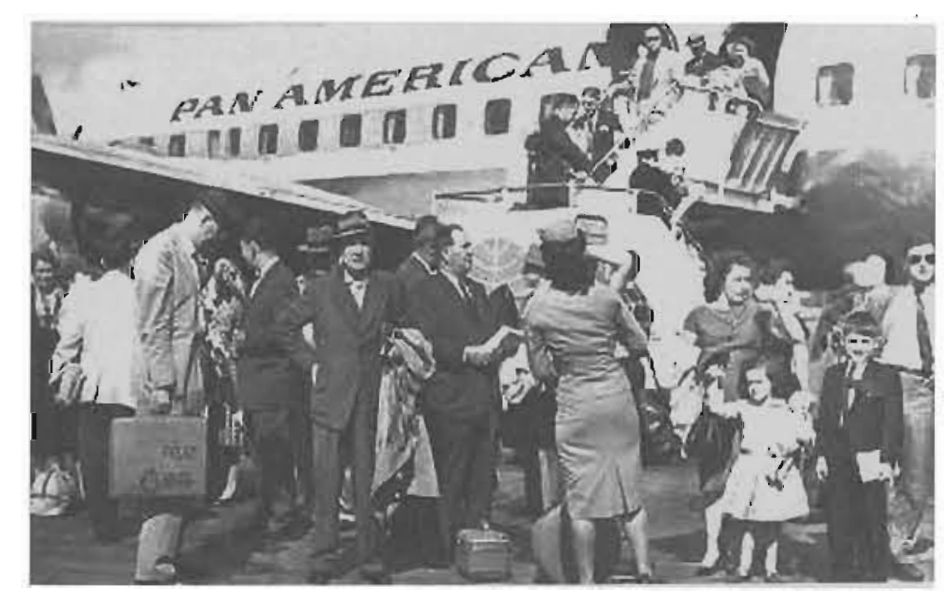

Figure 28. 1960 Well-dressed Cuban refugees arrive in Miami International Airport.

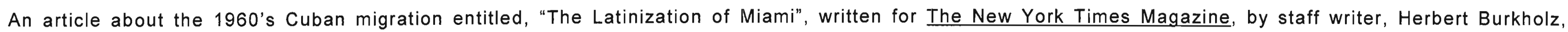

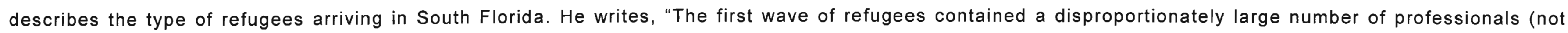




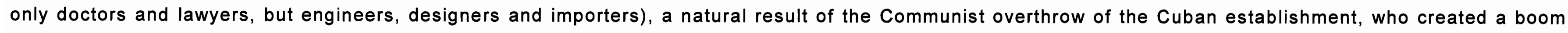
of their own through a series of economic ventures based on their special knowledge and expertise."1

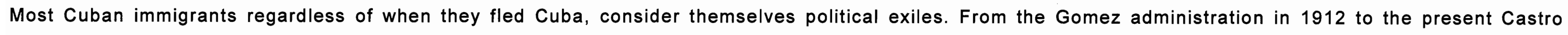

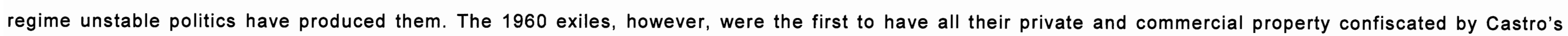

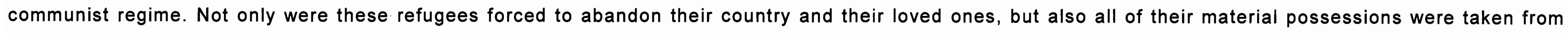
them. This circumstance is what makes the 1960 s Castro exiles different from previous Cuban exiles.

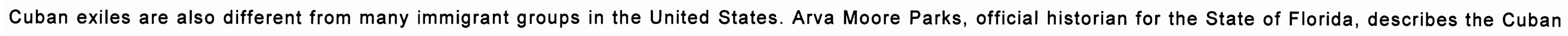

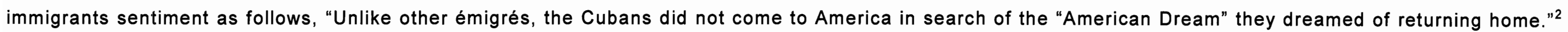

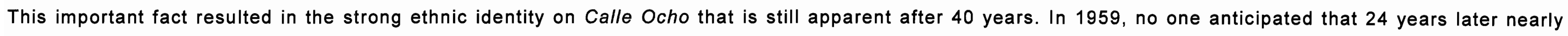
10 percent of the island population would be living in the United States, and mostly in the area of South Florida. ${ }^{3}$

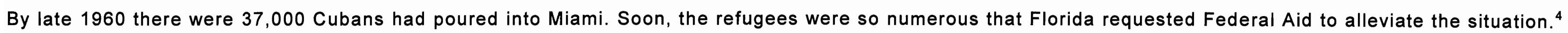

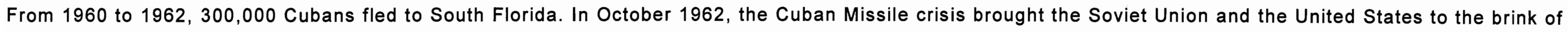
war. Cuba's borders were closed at this time, which prevented Cubans from leaving the island. ${ }^{5}$

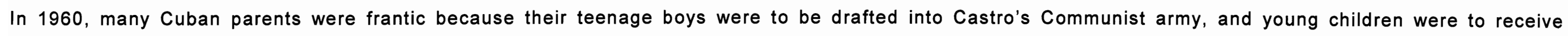

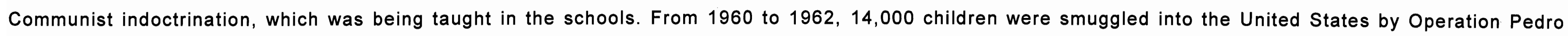

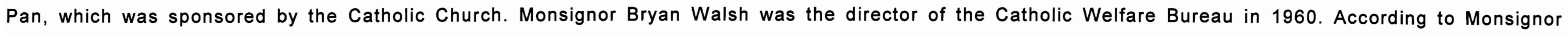

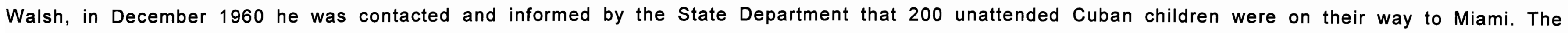




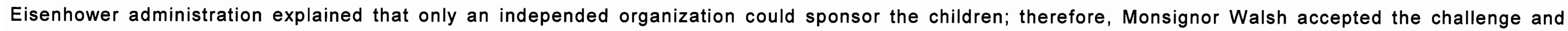
directed the Pedro Pan Operation. ${ }^{6}$

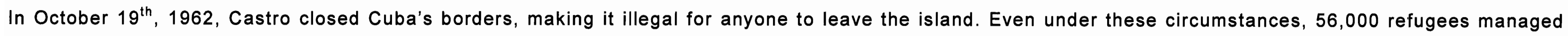

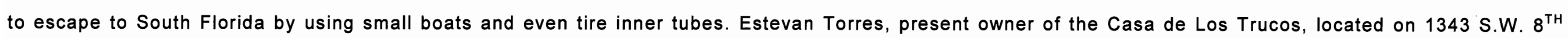

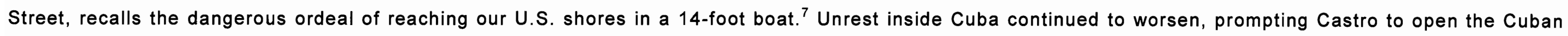

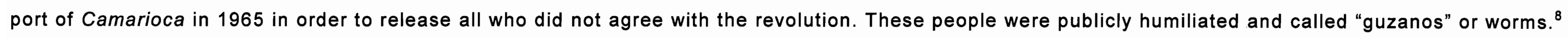

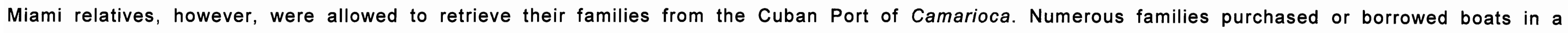

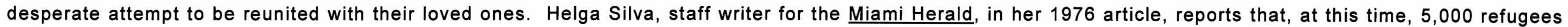

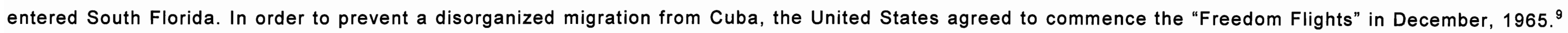

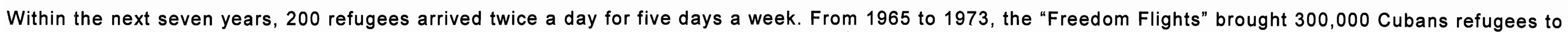

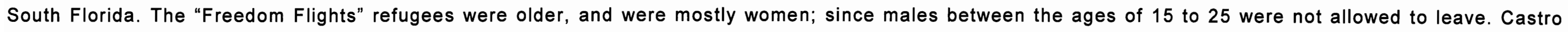

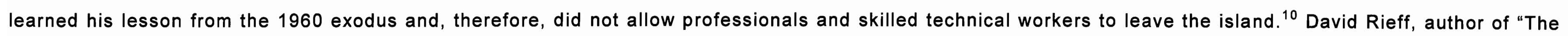

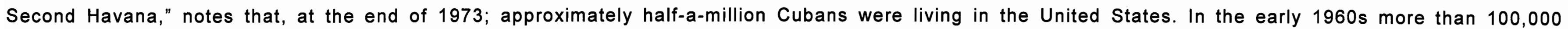

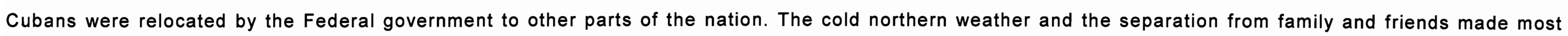
Cubans exiles return to Miami. ${ }^{11}$

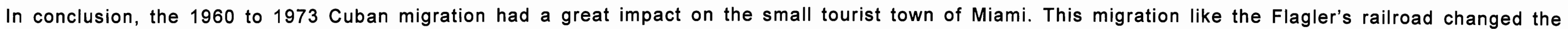

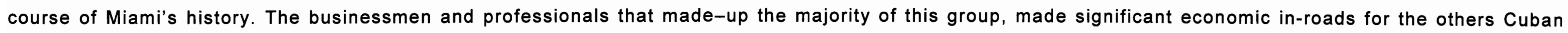
immigrant waves to follow. Using their ingenuity and their knowledge of the American commercial system, they assimilated economically in record time. 


\section{ENDNOTES:}

1. Burtkholz, Herbert. 1980. The Latinization of Miami. The New York Times Magazine, 21 September.

2. Moore Parks, Arva. 1993. Calle Ocho: Interpretive Center Concept and Documentation. Miami, Florida: City of Miami.

3. Ibid

4. Major Wave of Cuban Immigrants. 1999. Sun-Sentinel Co. \& South Florida Interactive, Inc. (cited 2 January 1999). http://www.Sun-Sentinel.com,

5. Sierra, J.A. The Timetable History of Cuba, Published in association with Amazon.com, 2000(cited 2 September 2000) http://www.historyofcuba.com

6. Walsh, Monsignor Bryan. 1993. History of the Cuban Children's Program: Operation Pedro Pan Group Inc. Miami, FI.: Conference, 26 June.

7. Torres, Esteban. 2000, Casa de Los Trucos Inc. owner, interview by author, Miami, Florida, 12 September 2000.

8. Collier, Bert. 1964. Miami and the Refugees: A History. The Miami Herald, January.

9. Silva, Helga. 1976. Freedom Flights Left Scars, Memories. The Miami News, 19 May.

10. Moore Parks, Arva. 1993. Calle Ocho: Interpretive Center Concept and Documentation. Miami, Florida: City of Miami.

11. Rieff, David. 1987. The Second Havana. The New Yorker, 18 May. 


\section{CHAPTER 4}

\section{CALLE OCHO:}

\section{THE TRANSFORMATION: 1960 TO 1973}

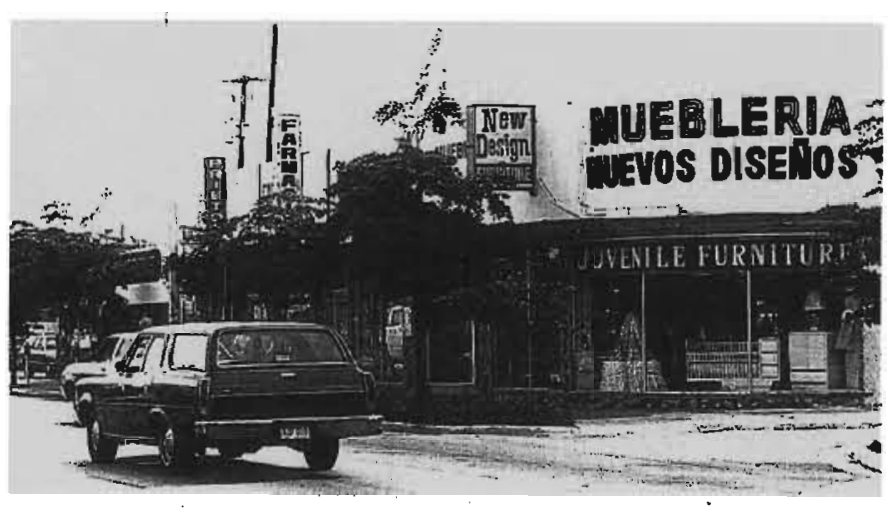

$1, \cdot$

Figure 29. $8^{\text {th }}$ Street $\& 6^{\text {th }}$ Avenue in 1969 signs are transforming into Spanish.

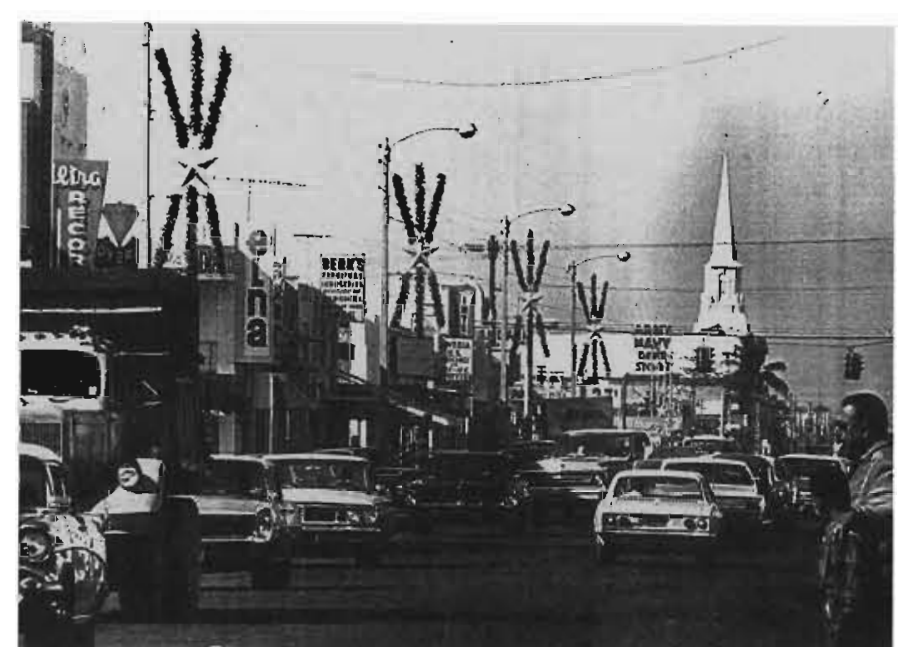

Figure $30.8^{\text {th }}$ Street $\& 17^{\text {th }}$ Avenue on December $24^{\text {th }}, 1968$.

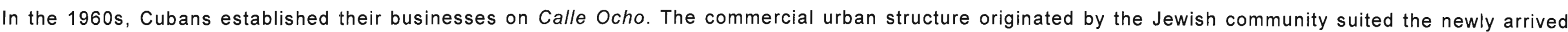

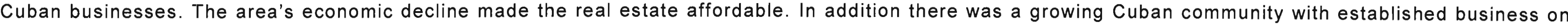

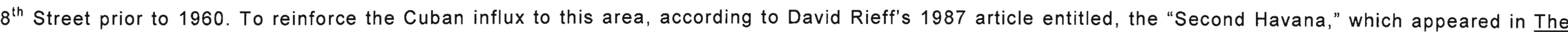

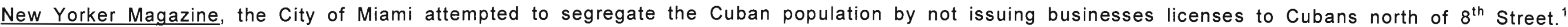

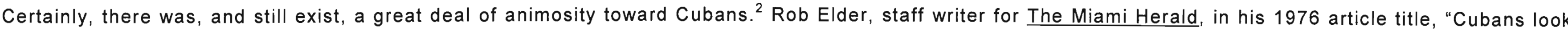

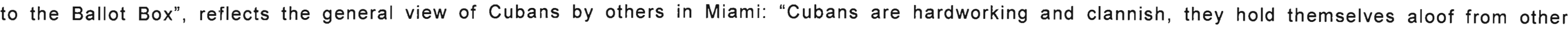




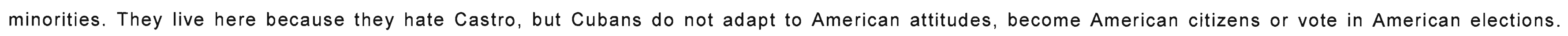

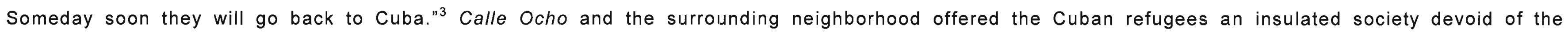

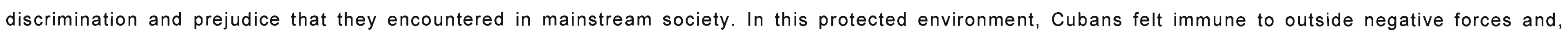

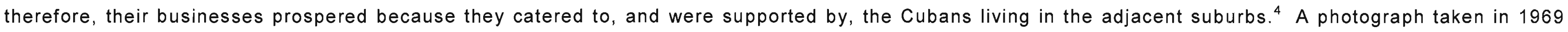

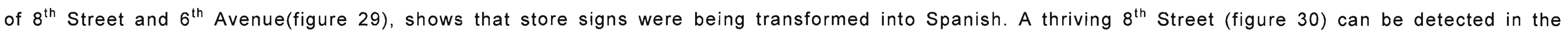

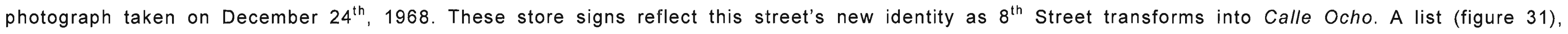

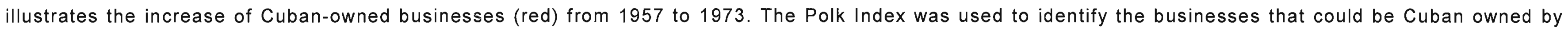

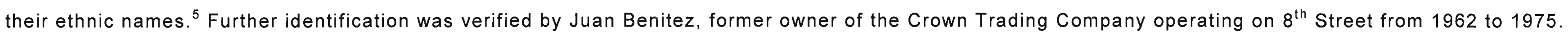

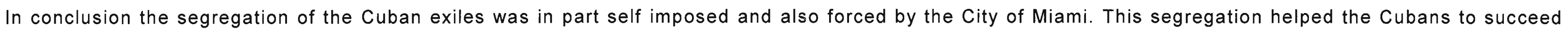

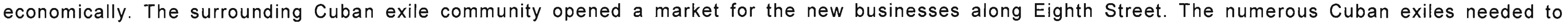
purchase literally everything and the stores on Eighth Streets catered to them.
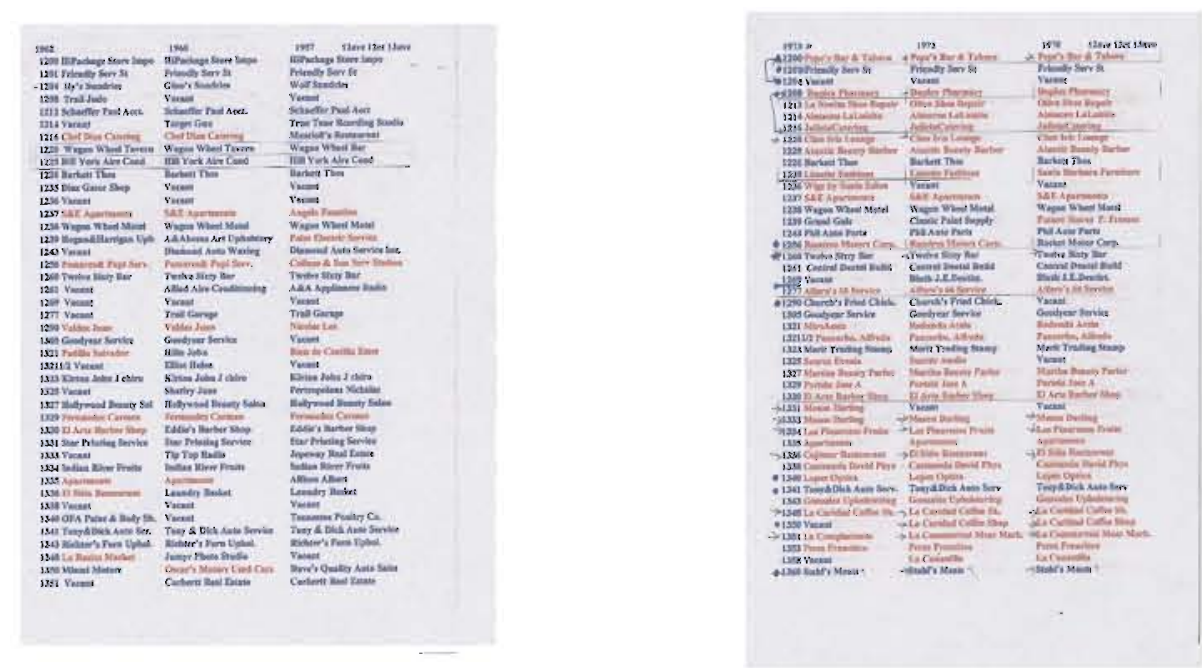

Figure 31. Documents, illustrating the Cuban-owned businesses (red) in Calle Ocho between $13^{\text {th }}$ and $17^{\text {th }}$ Avenues. 


\section{CAFÉ CUBANO:}

\section{A MAJOR FACTOR IN CALLE OCHO'S ETHNIC IDENTITY}
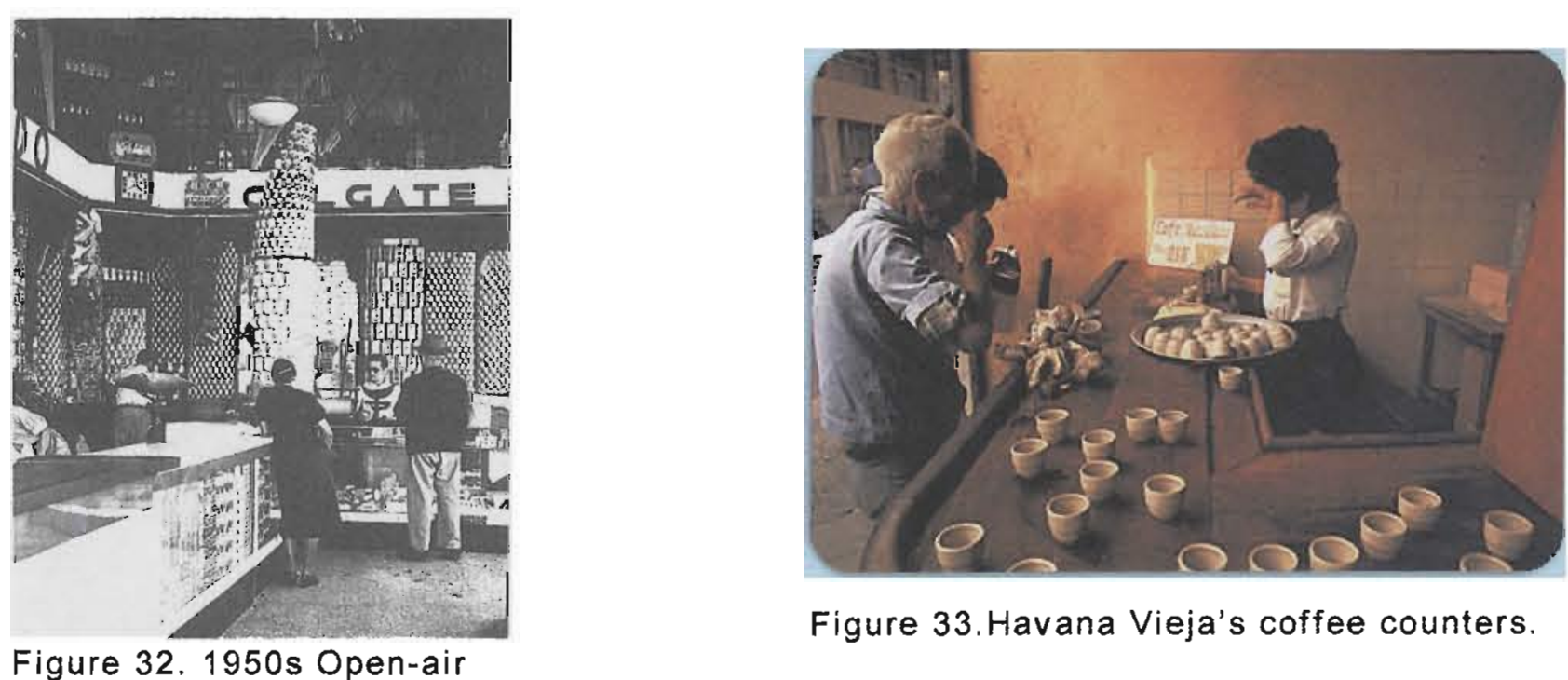

Figure 33. Havana Vieja's coffee counters

bodegas in Cuba.

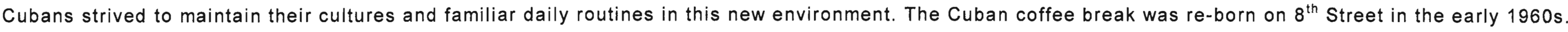

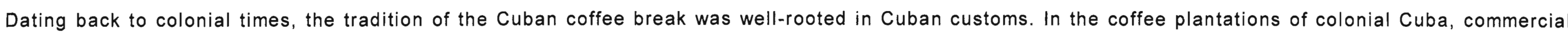

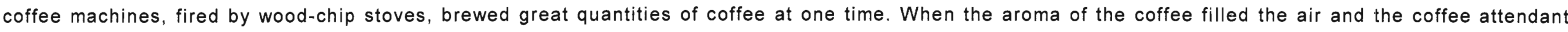

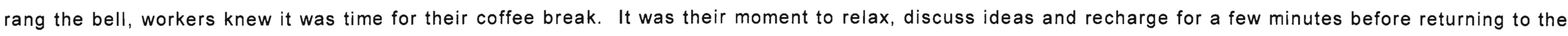

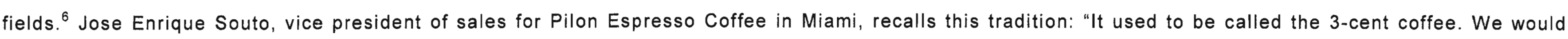

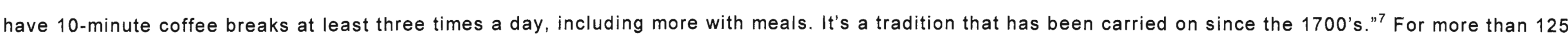

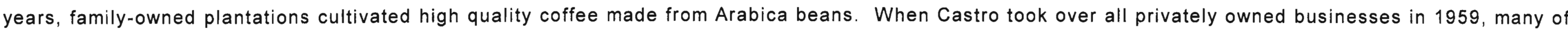

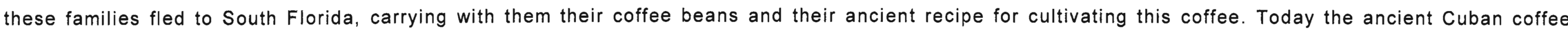
break tradition is transformed and blended into South Florida's urban life. ${ }^{8}$ 
The Cuban coffee break tradition was incorporated into the South Florida landscape with the transformation of the cafe windows in the storefronts of $8^{\text {th }}$ Street. In Cuba, coffee was brewed in open-air bodegas and sandwich shops that brought people into the establishment from the sidewalks. A photograph taken in Cuba in the early 1950s (figure 32), shows the open-air bodega. A more resent photograph (figure 33), indicates the strong coffee counter relationship with the pedestrians in La Havana Vieja. The café windows of Calle Ocho facilitate the continuation of the Cuban coffee break tradition by offering the opportunity for casual conversation in an urban setting. The café windows also physically altered the design of the standard storefronts, therefore, creating a unique ethnic identity.

Since 1961, Cuban exiles adapted the existing storefronts by creating a window so that coffee could be served to pedestrians on the sidewalks. The consumption of this intense coffee naturally sparks animated discussions ranging from politics to baseball to local gossip. ${ }^{9}$ According to Monica Ponce De Leon, architect and urban planner, "These (café windows) are extremely popular for people on their way to work in the morning, coming back at night from the movies, or after particular events, when the crowd in the lots can number up to 50 people. Ironically, it is here where the Cuban community exchanges discussions about Castro, recounts old times in Cuba or maps out its role in Miami's political life. ${ }^{10}$ The cafe windows provide an environment were the community can network. Bill Barry, staff writer for The Miami Herald in his 1967 article entitled, "Cuban Dream at their Cafetins," discusses the role of the café window as centers of neighborhood news. This information could range from the location of a loved one or friend, job openings, or the latest political news from Cuba. ${ }^{11} \mathrm{It}$ can be assumed that the café windows were instrumental in the economic and political success and assimilation of the Cubans in South Florida. The café windows have also developed with time becoming more adaptable and functional. A typical cafe window in the mid-1960s (figure 34), already shows signs of adaptation, notice the Spanish advertisement on the upper glass window panel. 


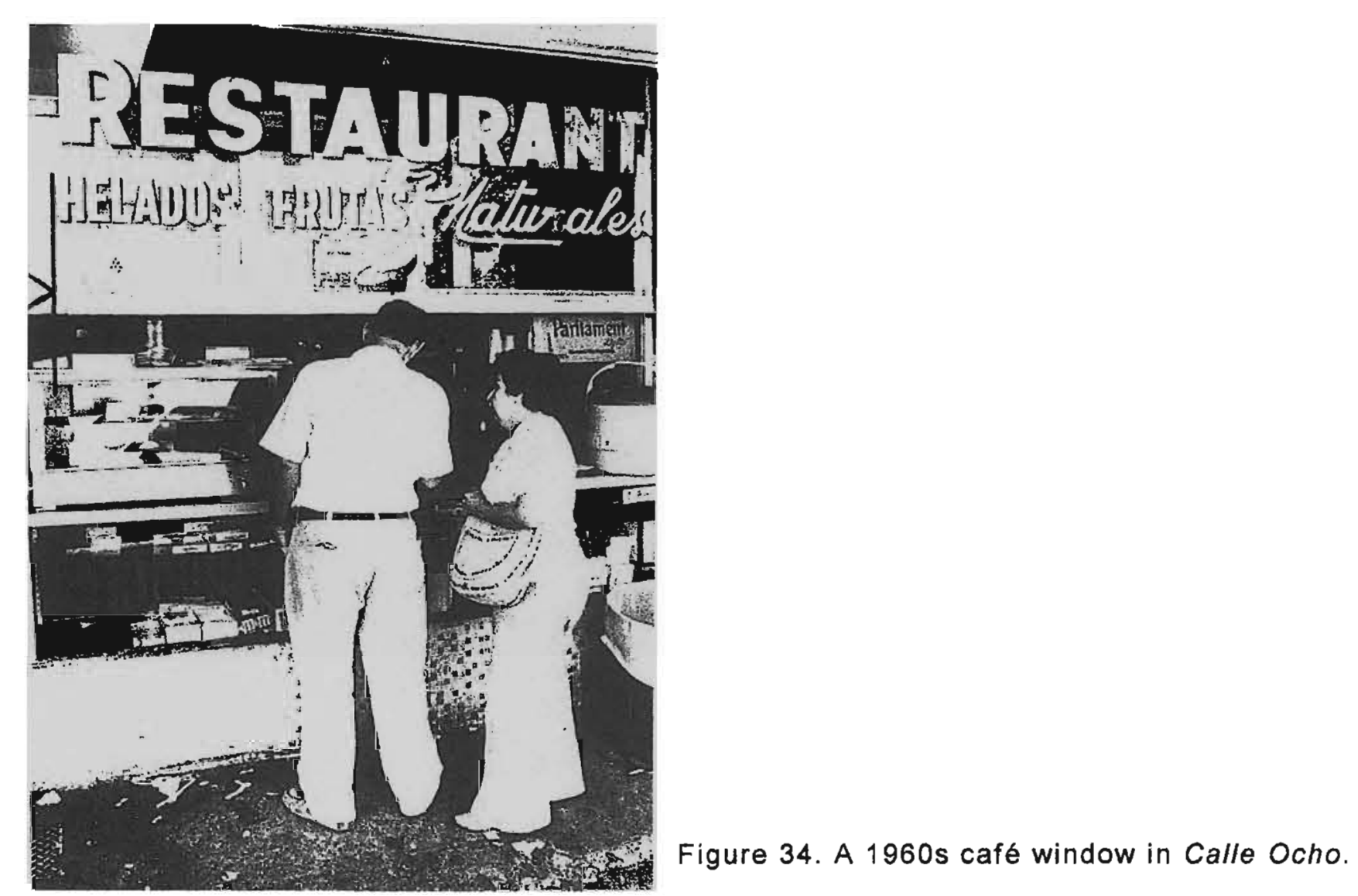

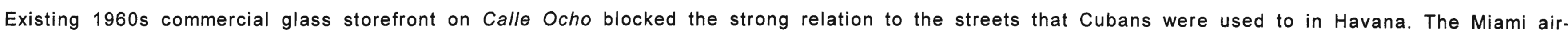

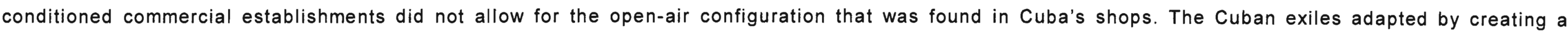
window were coffee was served to pedestrians.

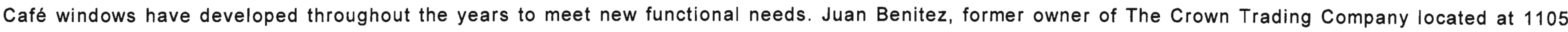

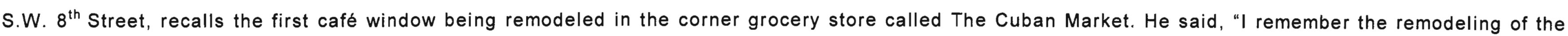

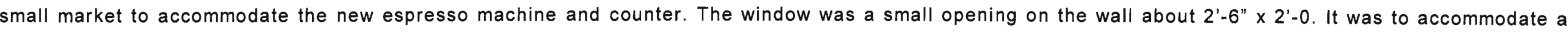

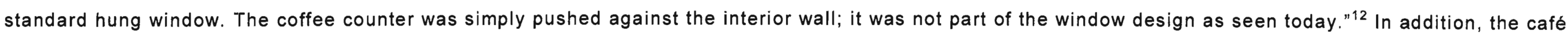

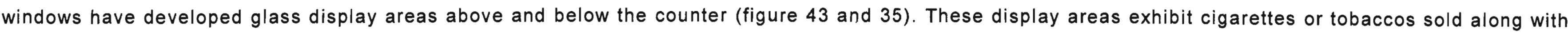




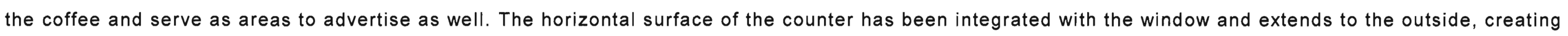

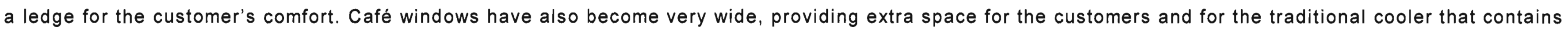

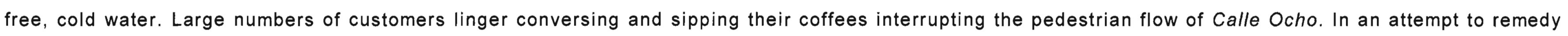

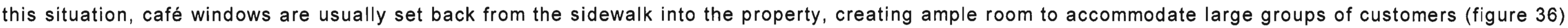

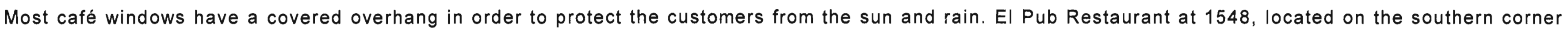

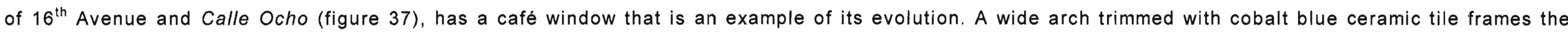
café window. The window is at approximate 45-degree angle from the street, which creates ample room for various customers to linger and chat.

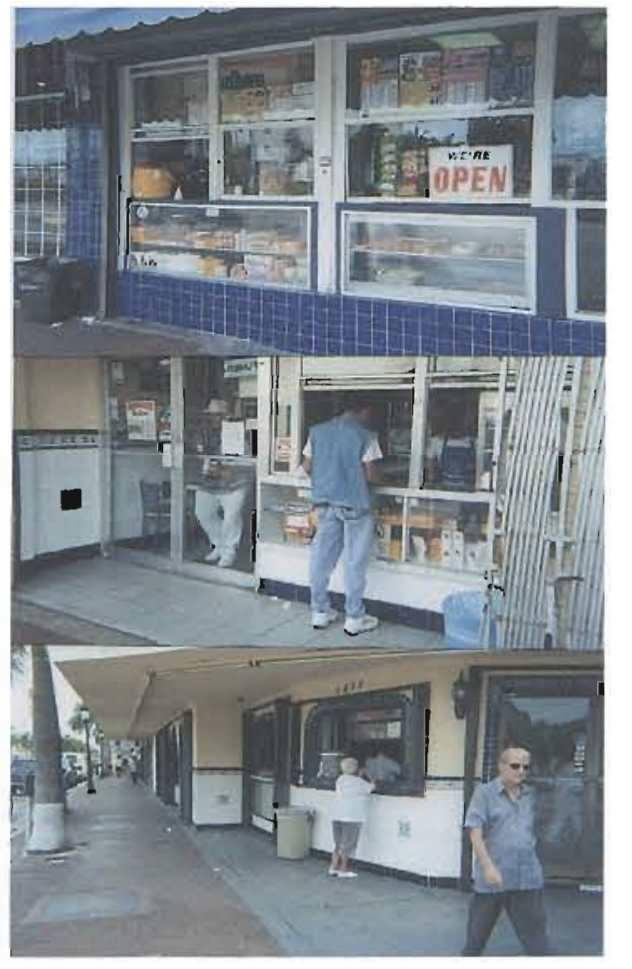

Figure 35. Café windows have developed since the 1960 s to include display windows.

Figure 36. Cafe window are sometimes recessed into the property to provide ample space for the customers.

Figure 37. El Pub Restaurant's café window is a great example of this evolution.

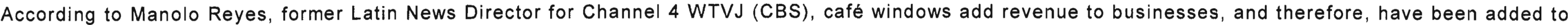

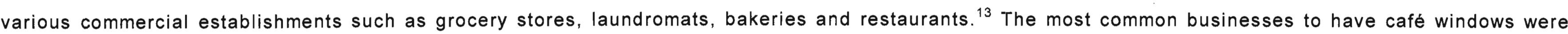

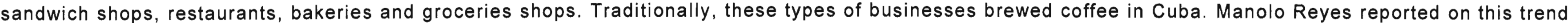

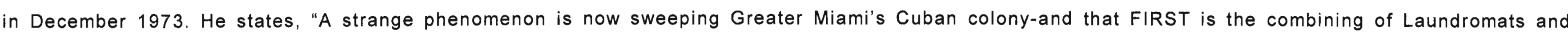


coffee shops under a single roof. There are at least half a dozen of these unusual business enterprises that have spouted in Dade County during the past year." ${ }^{14}$ In any business where a cafe window has been adapted, it has facilitated a strong relationship with the pedestrian; and this is an essential factor in the traditional Cuban urban fabric that adds ethnic identity to this otherwise ordinary street. Café windows, today, can be found in almost every shopping center around South Florida. ${ }^{15}$

Café windows can be seen as an example of the adaptability of the Cubans exiles. Cuban found a way of having their daily shot of Cuban coffee and promote the social interaction that it accompanies by the creation of these windows. Both coffee and social contacts are essential part of Cuban daily life.

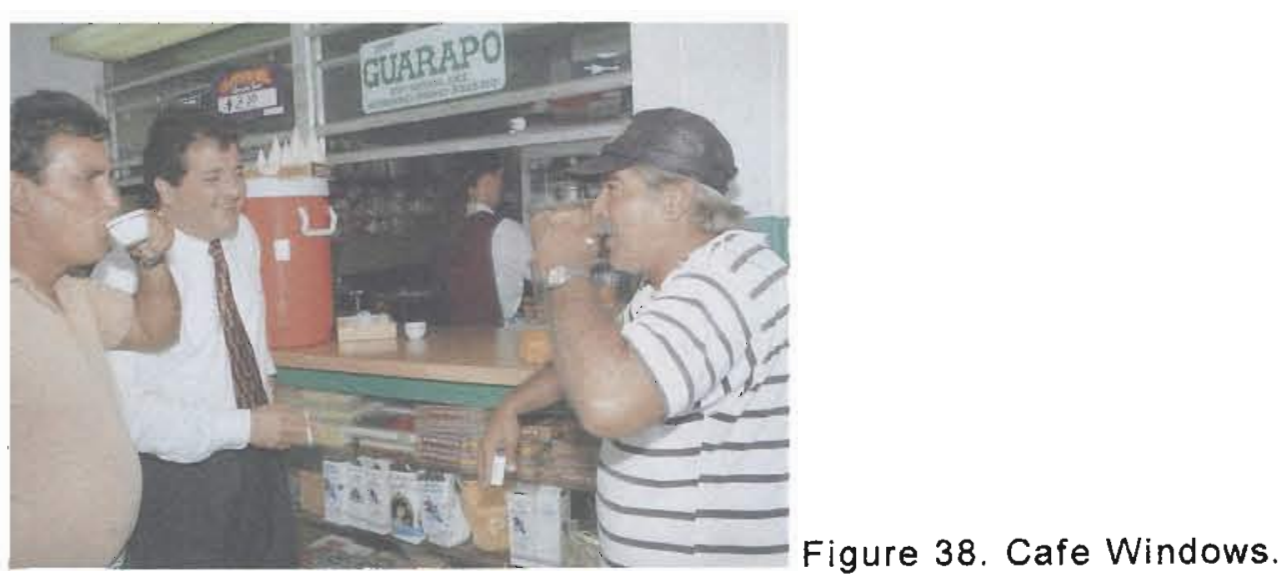




\section{CUBAN RESTAURANTS:}

\section{CUBAN CUISINE PROMOTES ITS CULTURE}

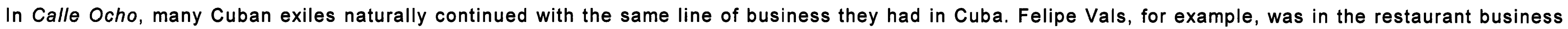

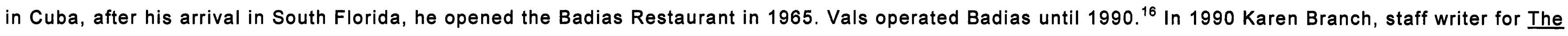

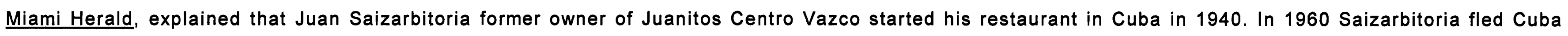
and started a restaurant again on Calle Ocho and $37^{\text {th }}$ Avenue. Sazaibitoria designed his restaurant in a similar fashion to the one he left in Cuba. ${ }^{17}$

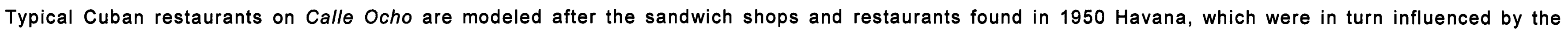

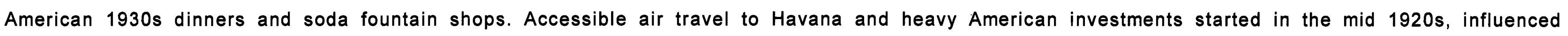

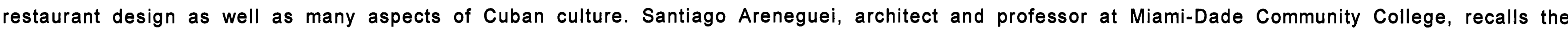

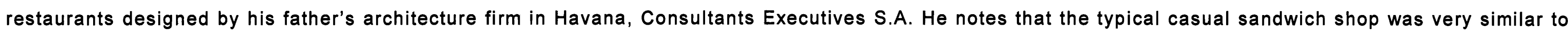

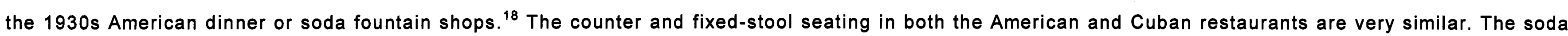

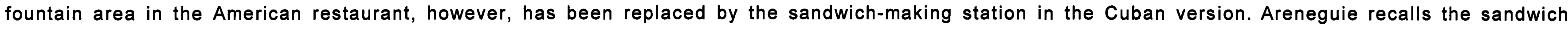

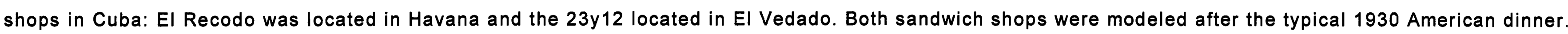
19

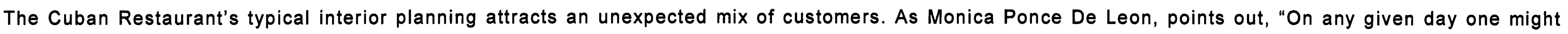

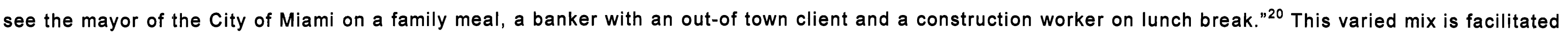




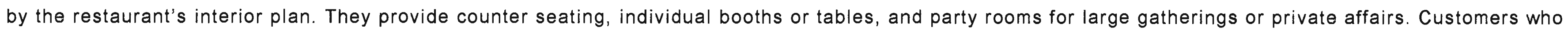

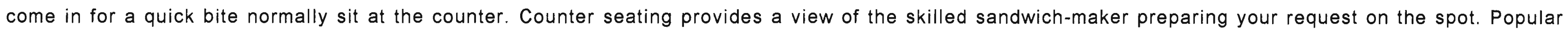

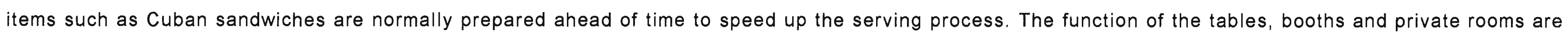
similar to other area restaurants. ${ }^{21}$

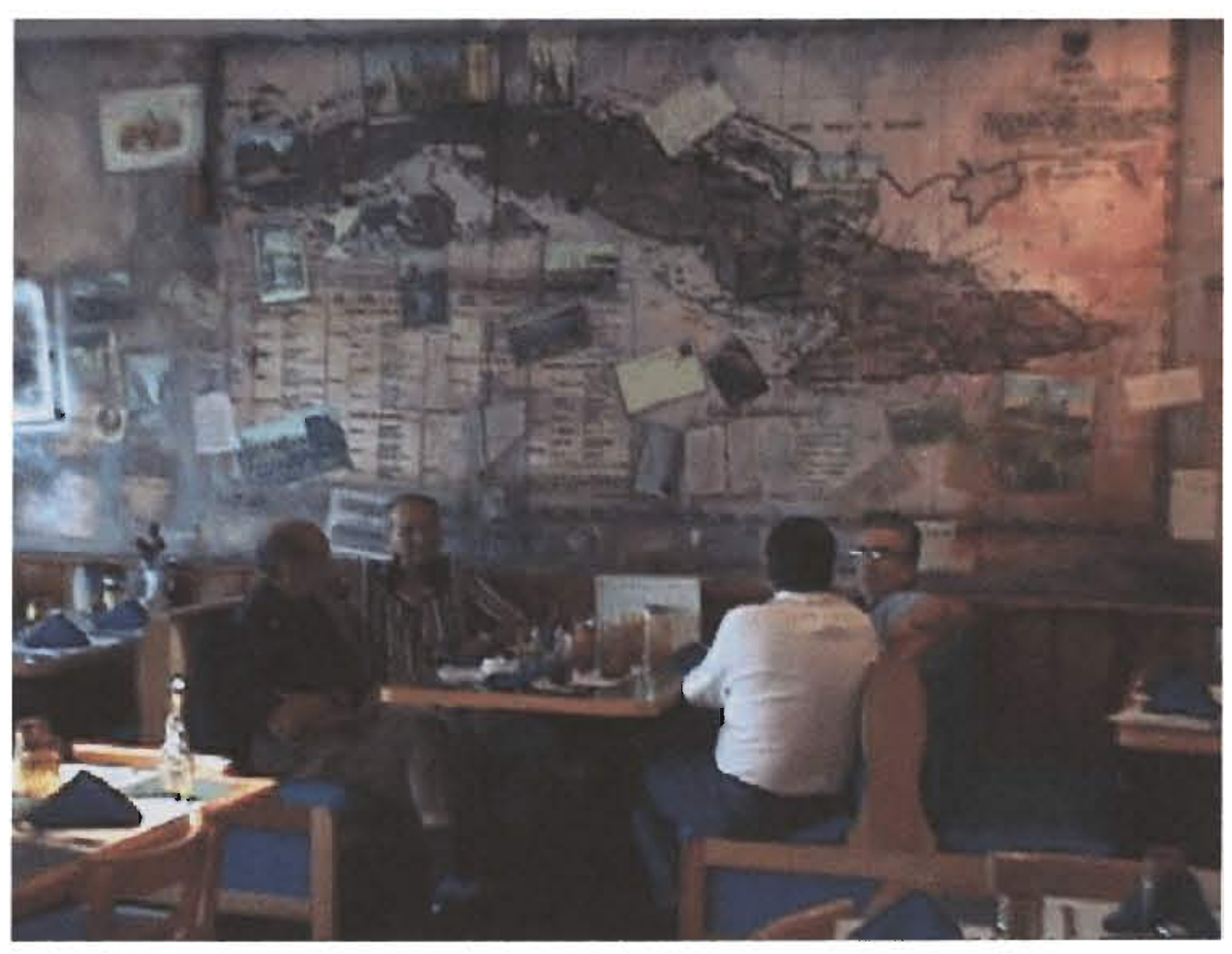

Figure 39. El Pub decorative map of Cuba

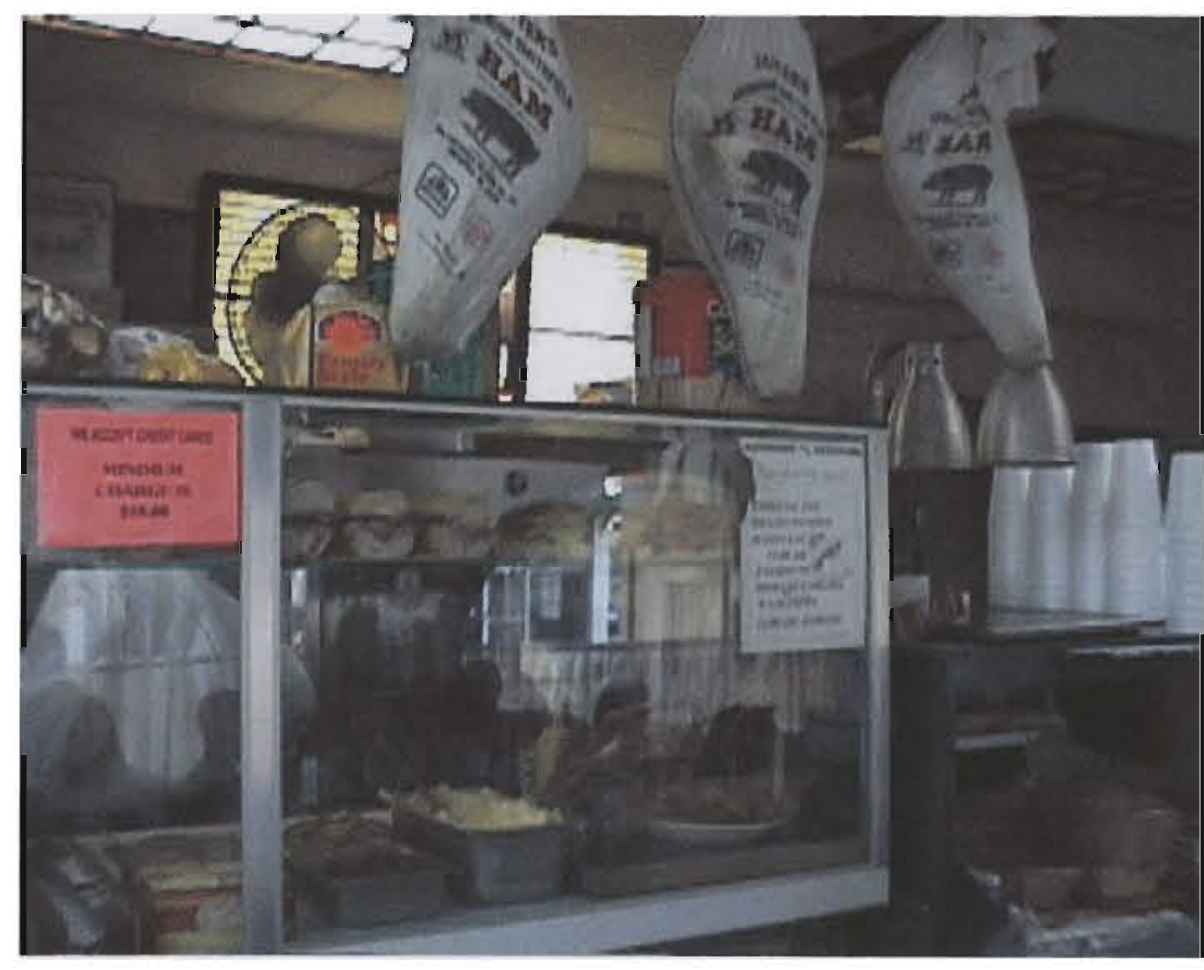

Figure 40 . Sandwich counter with the hanging cured hams.

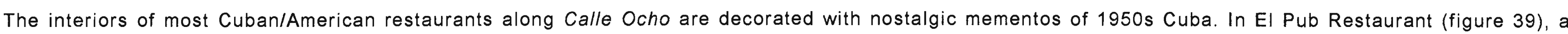

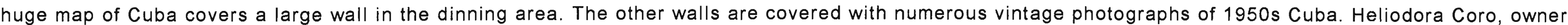

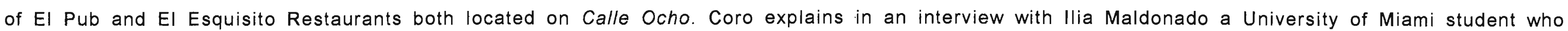




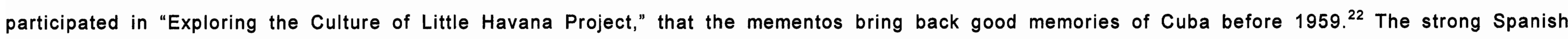

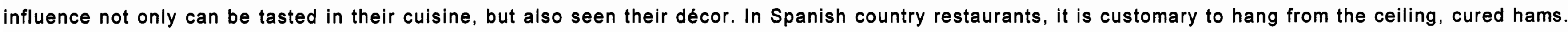

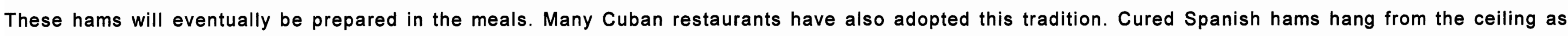
decorations at the sandwich counter at El Pub Restaurant (figure40). ${ }^{23}$

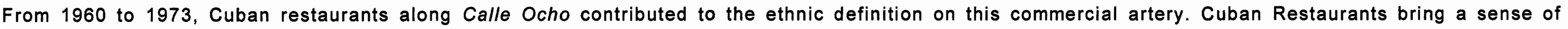
nostalgia with their typical cuisine and visual reminders of the homeland. 


\section{TOBACCO MANUFACTURING:}

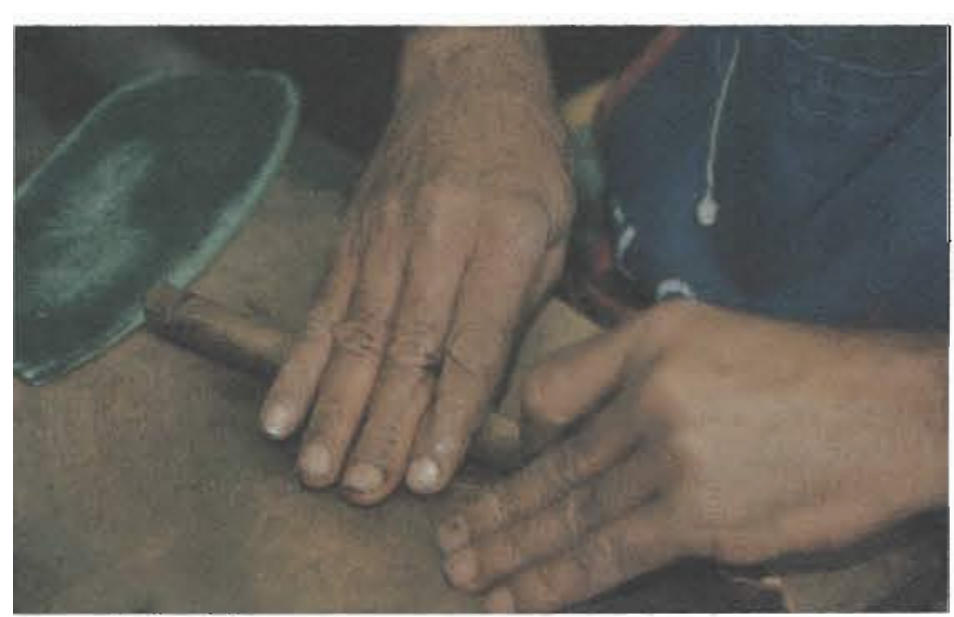

Figure 41. Cigar-rolling skills are

Passes down by generations.

\section{Figure 42. Most tobacco hand rollers}

Are second generation Cuban. (right)

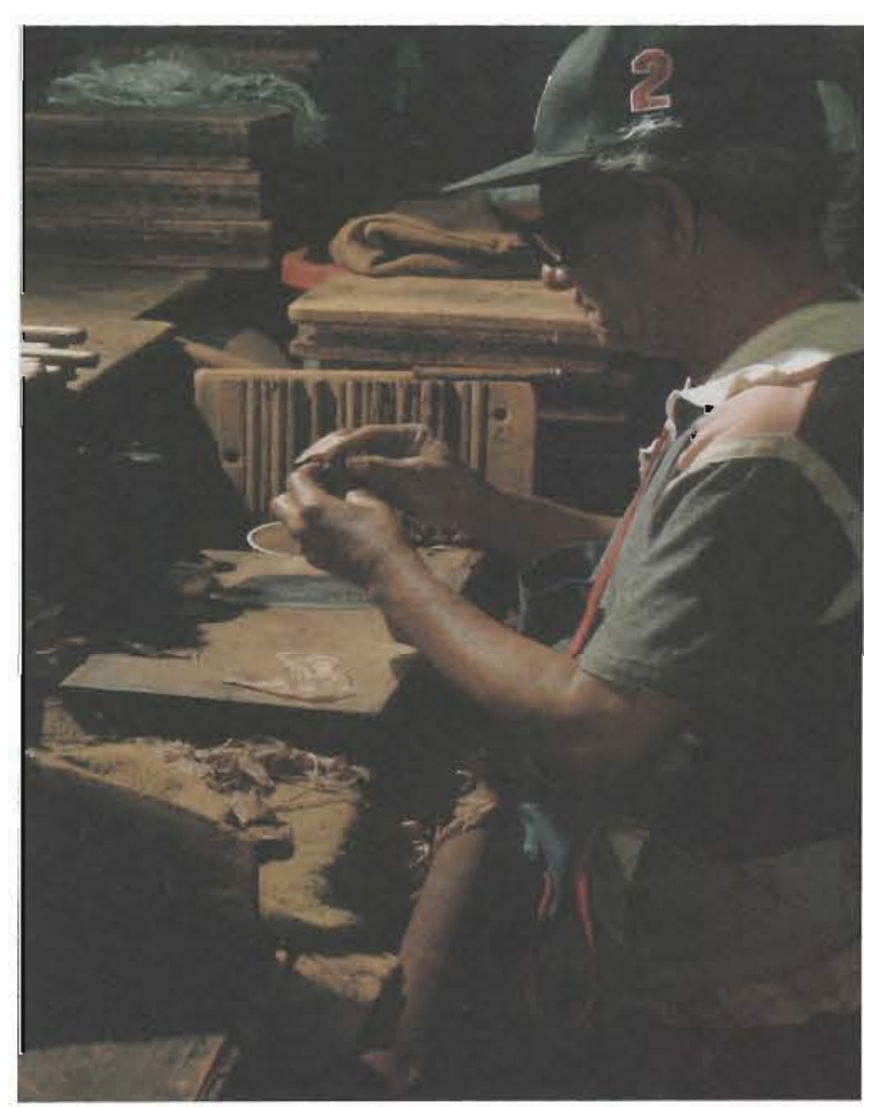

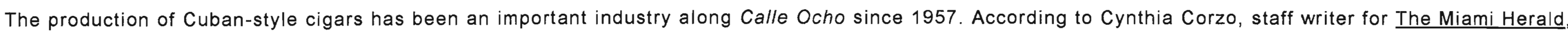

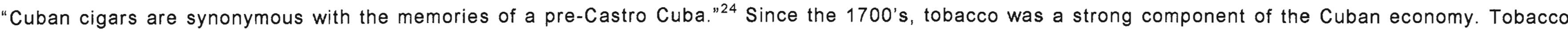

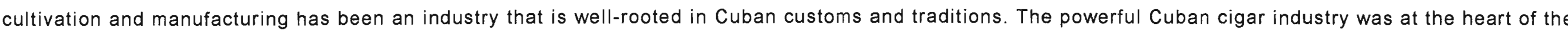




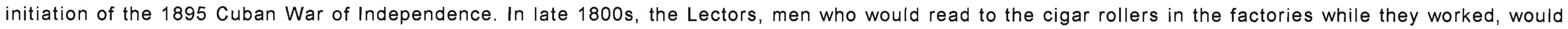

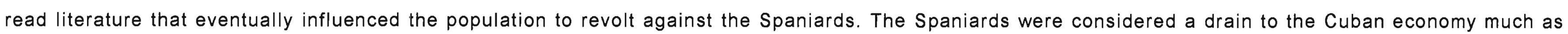

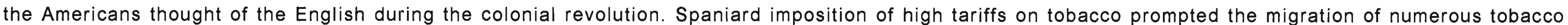

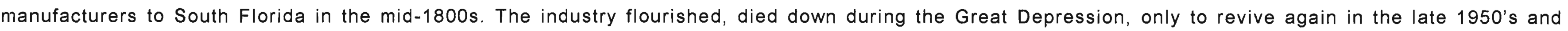
early 1960 s. $^{25}$

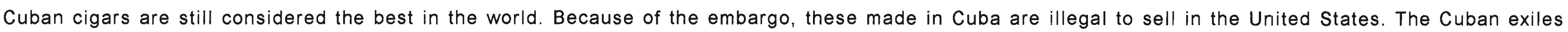

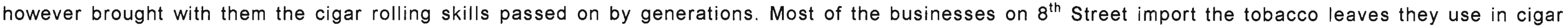

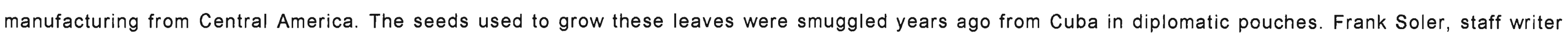

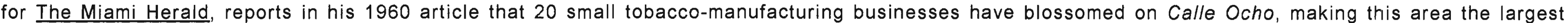

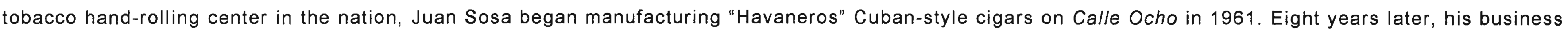

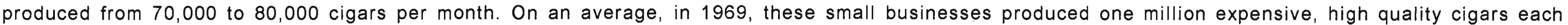
month. In 1996, the production of cigars was not enough to satisfy the market demand. ${ }^{26}$

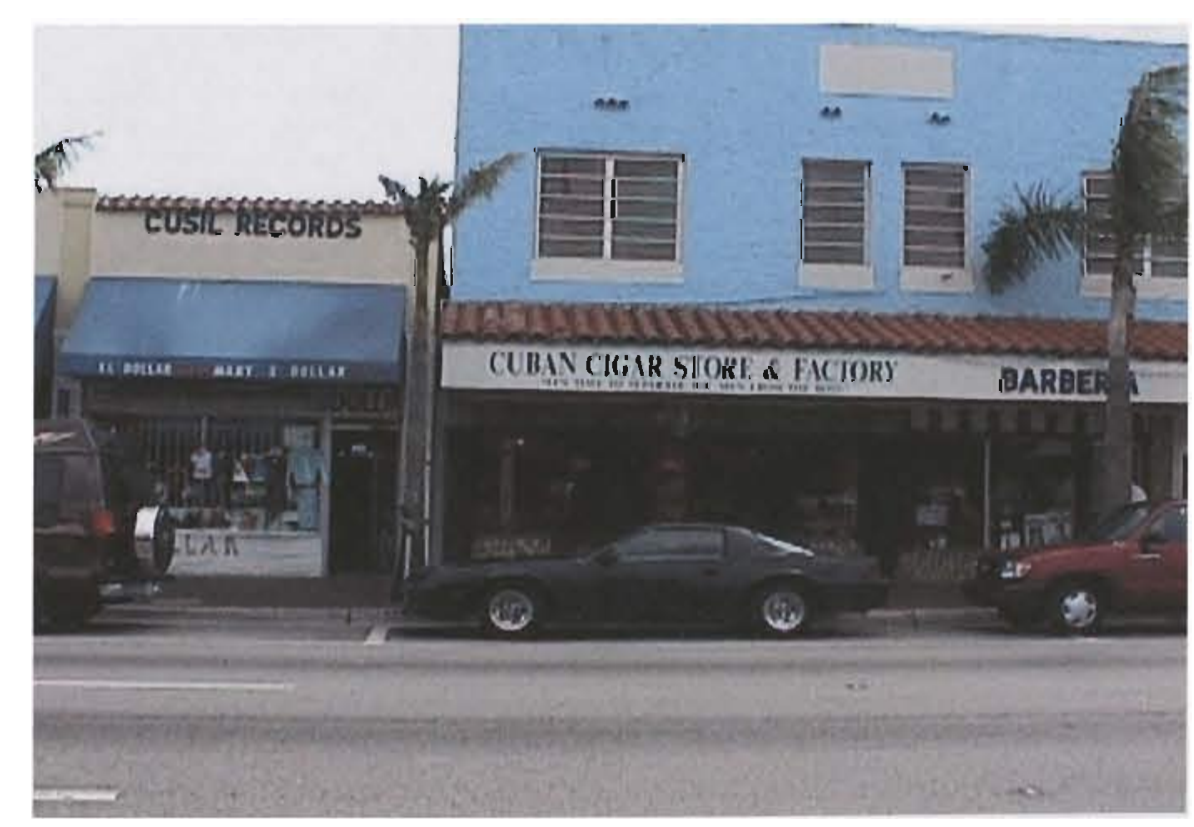

Figure 43. Typical cigar manufacturing on Calle Ocho. 


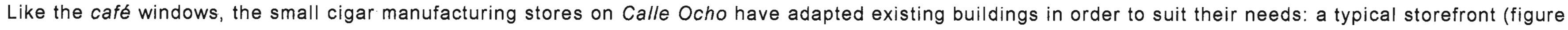

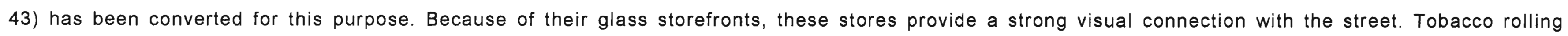

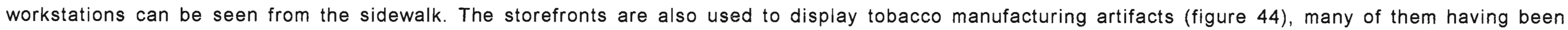
brought from Cuba. The tobacco manufacturing establishments have become a popular stop for the tourist busses that visit the area on a regular basis. ${ }^{27}$

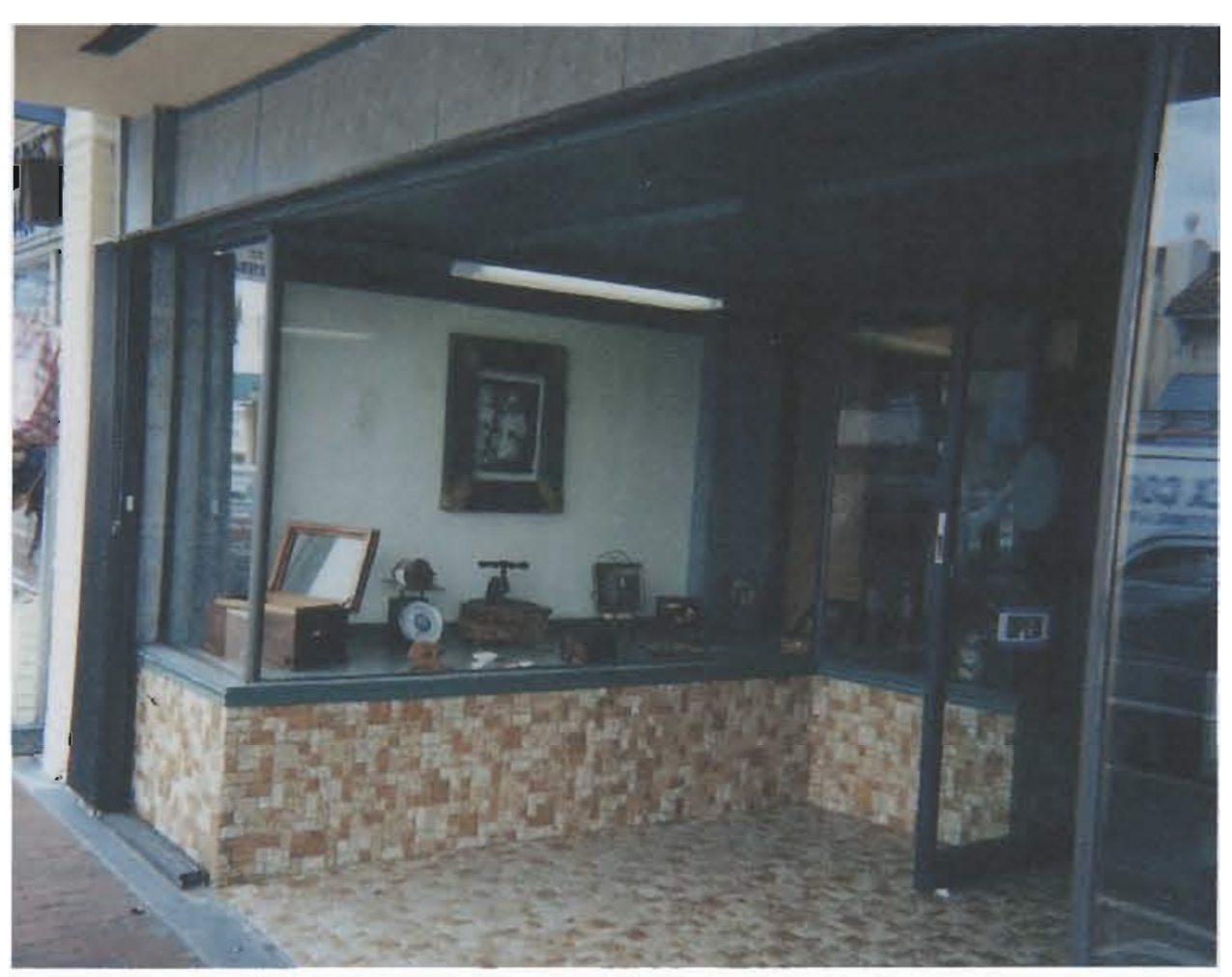

Figure 44. Typical cigar manufacturing display in storefront windows. 


\section{MONUMENTS:}
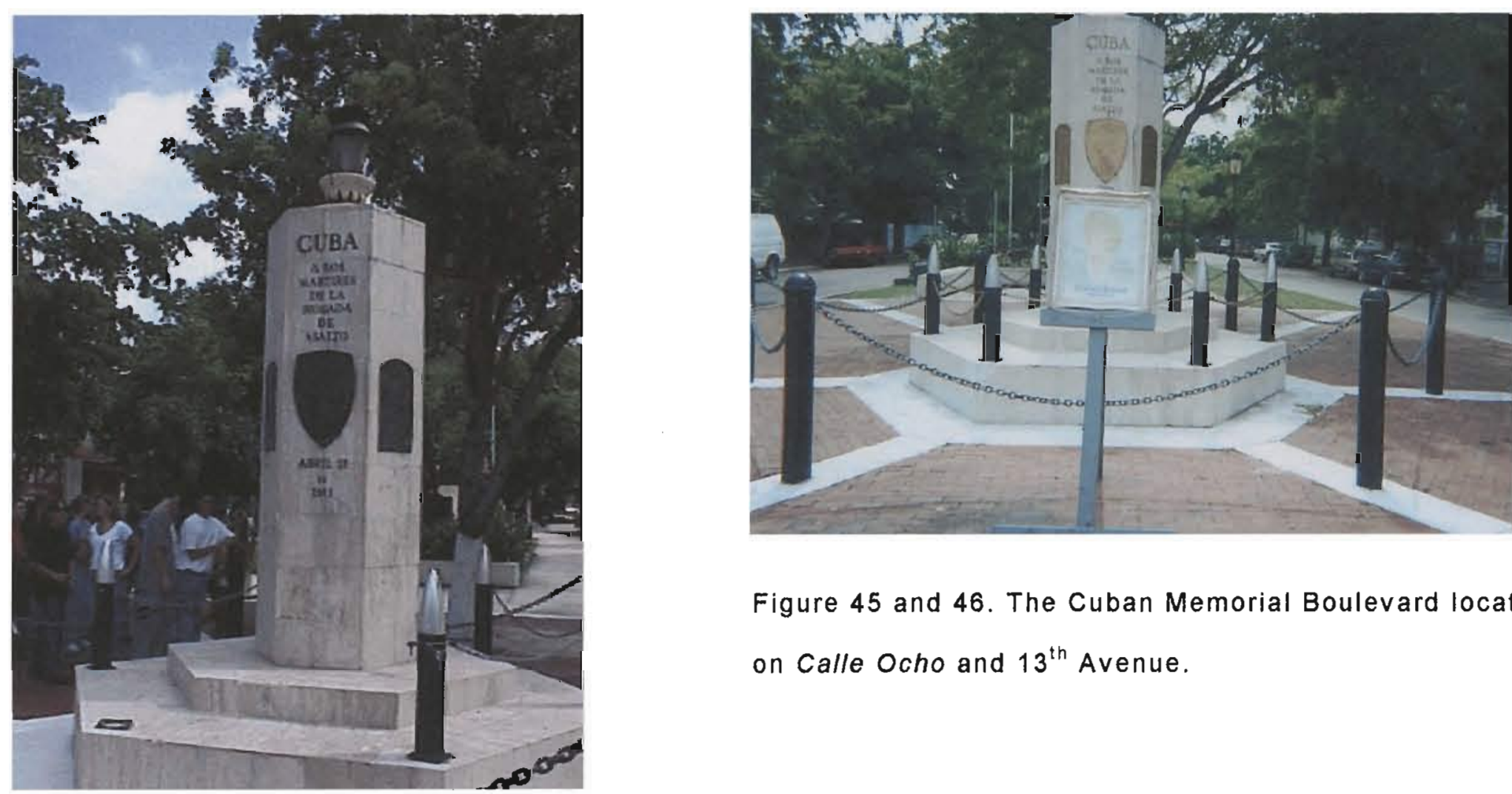

Figure 45 and 46 . The Cuban Memorial Boulevard located

on Calle Ocho and $13^{\text {th }}$ Avenue.

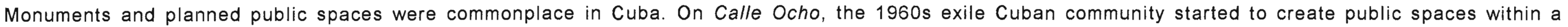

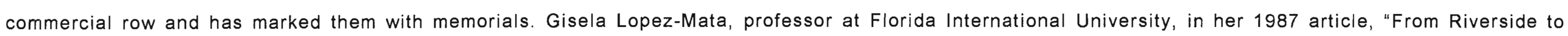

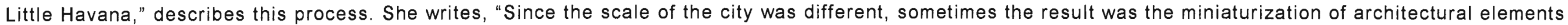

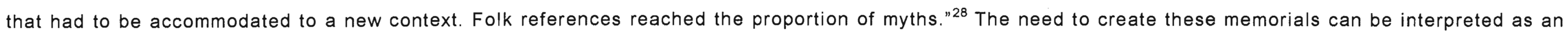

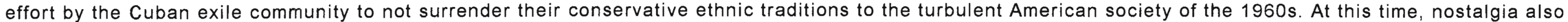
prompted the Cubans to surround themselves with folkloric symbols of an idealized past era. 
A memorial to the victims of the Bay of Pigs Memorial invasion is an outward sign that unified the 1960 s Cuban community. The memorial, located at $13^{\text {th }}$ Avenue and Calle Ocho, honors the memory of the 114 Cubans of the Brigada 2506 who lost their lives, and the 1,189 others who were captured and imprisoned while attempting to liberate Cuba on April $17^{\text {th }}, 1961 .{ }^{29}$ Juan Clark, former member of Brigada 2506 and a professor at Miami-Dade Community College, states that the CIA trained the Cuban volunteers of Brigada 2506 to invade Cuba in an effort to reclaim the island nation. At the last minute, the United States withheld their promised air support, which caused the invasion to fail. As a result, Juan Clark, along with over 1,000 young volunteers, were imprisoned in a Cuban jail for two years. ${ }^{30}$ This painful and bitter memory that cannot be forgotten unified the 1960 s Cuban community.

The Bay of Pigs Memorial was financed with donations from the Cuban community. Cuban business mainly located on Calle Ocho contributed heavily toward the construction fund of this memorial. It was dedicated on April $17^{\text {th }} 1971$. At the opening ceremony, the torch was light by Rebecca Guerra, who lost her father to the invasion when she was an infant. ${ }^{31}$ The memorial was designed as a modest marble clad monolithic structure with a permanent burning torch located on a miniscule formal plaza (figure 45, 46). Every time the Cuban community had to protest, celebrated an event such as the past anniversaries of Cuba's Day of Independence on May $20^{\text {th }}$, this memorial was a place where the Cuban community gathered. ${ }^{32}$

The parkway located on $13^{\text {th }}$ Avenue existed since 1912, it is a beautiful shaded street with a generous, green median strip and wide sidewalks. In the late 1960 s, the City of Miami named it the Cuban Memorial Boulevard and since then has become the site of several mini monuments and small plazas, that commemorate Cuban history and religion. Jose Casanova, City of Miami Planner, re-designed the boulevard in the early 1970s. He recalls the efforts to safe the enormous cieba tree which sits in the middle of the median. An existing electrical power line, ran through the middle of the boulevard was damaging the upper canopy of the cieba tree. In order to save the tree, Casanova urged the City of Miami to request a small electrical easement behind the properties adjacent to the boulevard. The shade of the cieba and the other trees planted along its wide sidewalks serve as a comfortable pedestrian walkway for the neighborhood. 


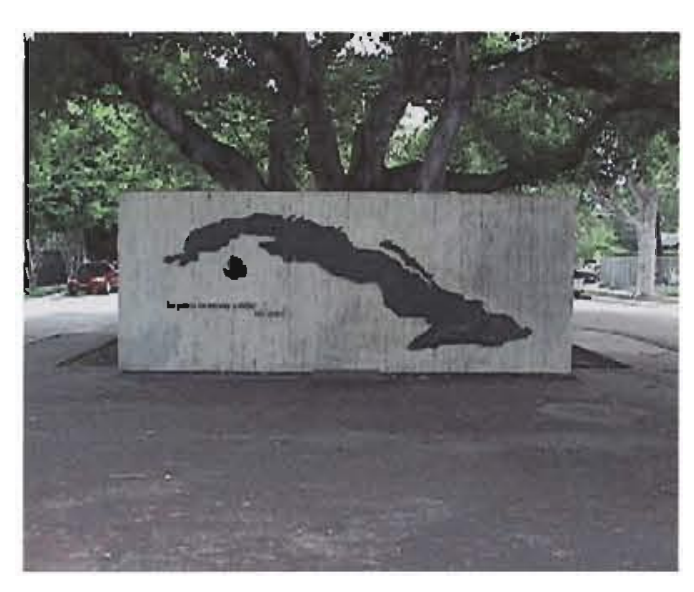

Figure 47. Isla de Cuba Memorial.

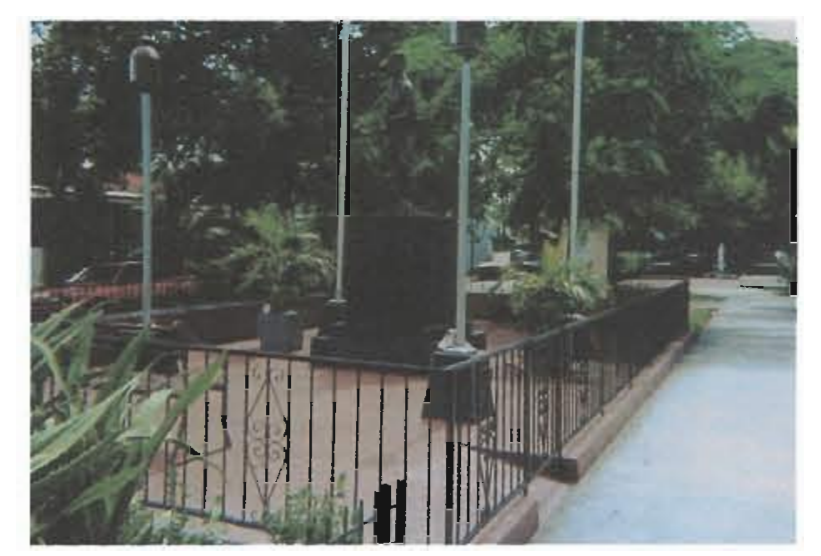

Figure 48. Nestor Isquierdo Memorial.

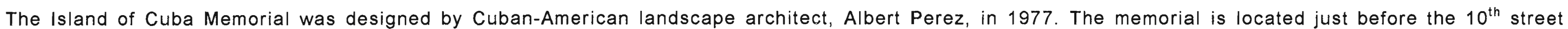

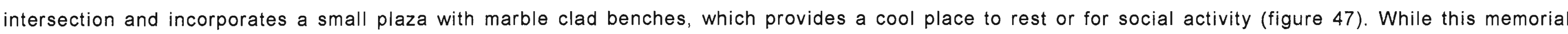

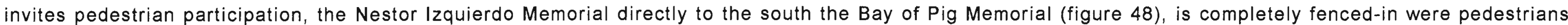

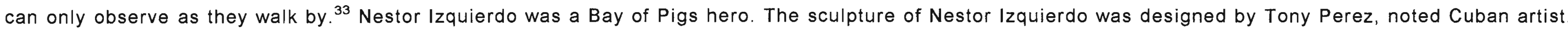
The Acion Cubana financed his memorial which was installed on August $27^{\text {th }}, 1992$.

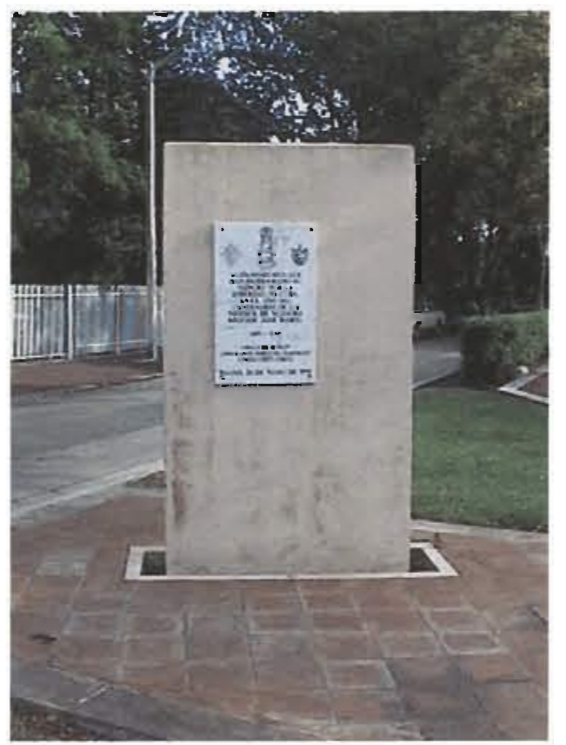

Figure 49. Jose Marti/Virgen de La Caridad Memorial.

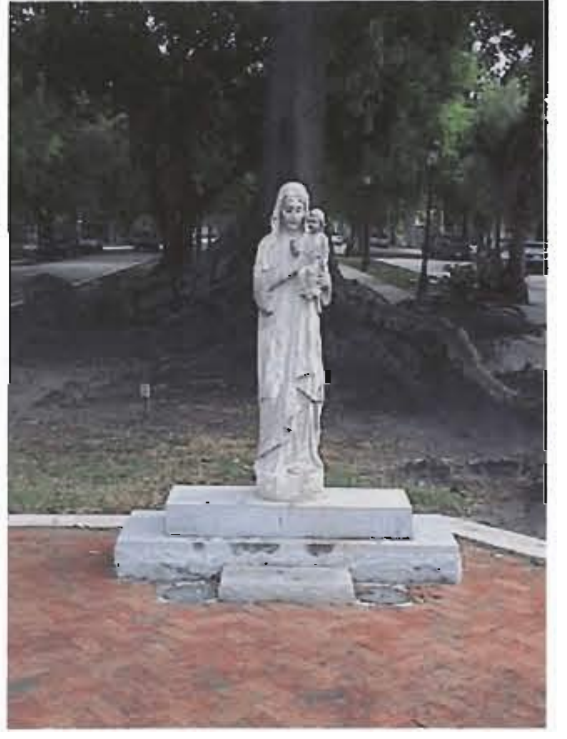

Figure 50. Monumento a Las Madres. 


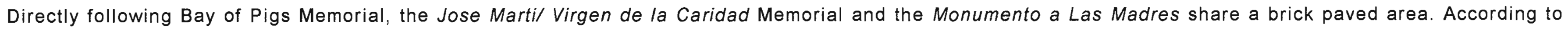

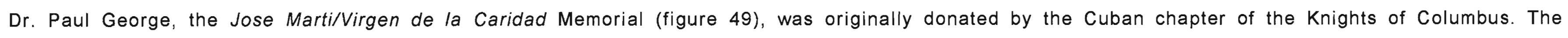

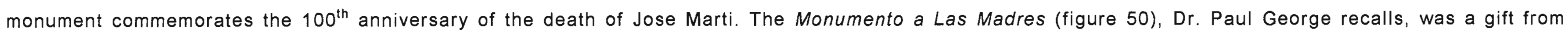

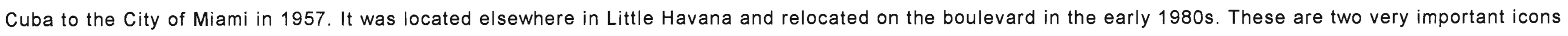

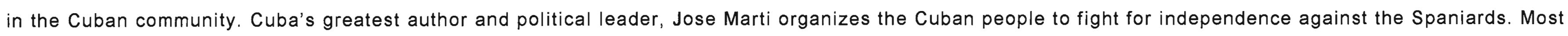

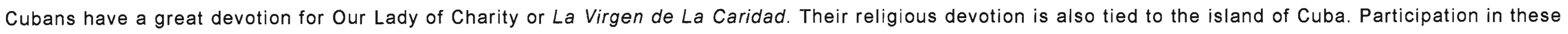

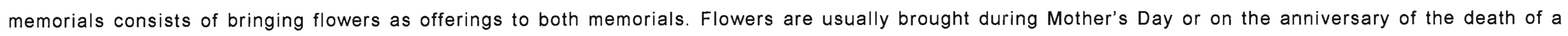
loved one. ${ }^{34}$

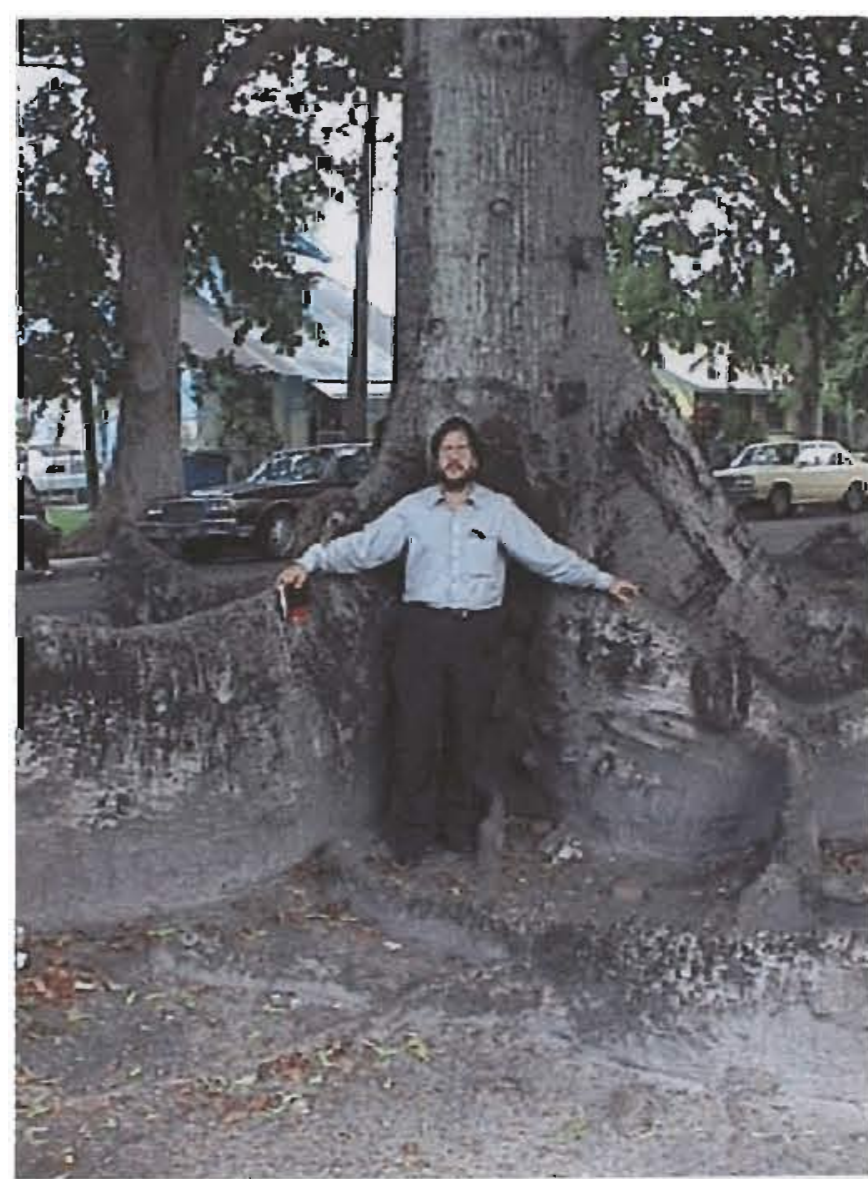

Figure 51. Ceiba tree in the boulevard. 


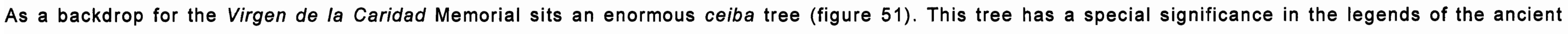

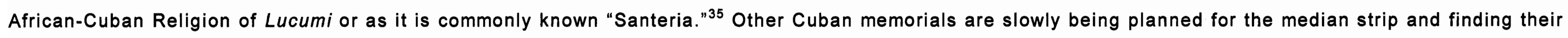
way to toward Coral Way. This boulevard is just one of many outward symbols marking the presence of the Cuban presence in this neighborhood.

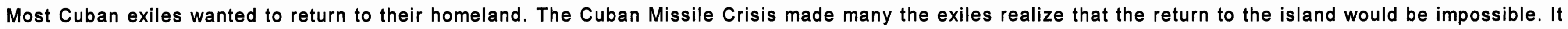

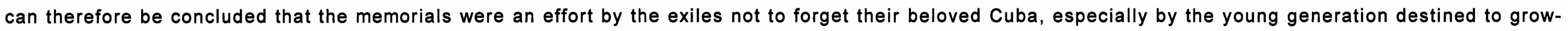
up in the United States. 
PARK:

\section{SENIORS ENJOY CALLE OCHO}

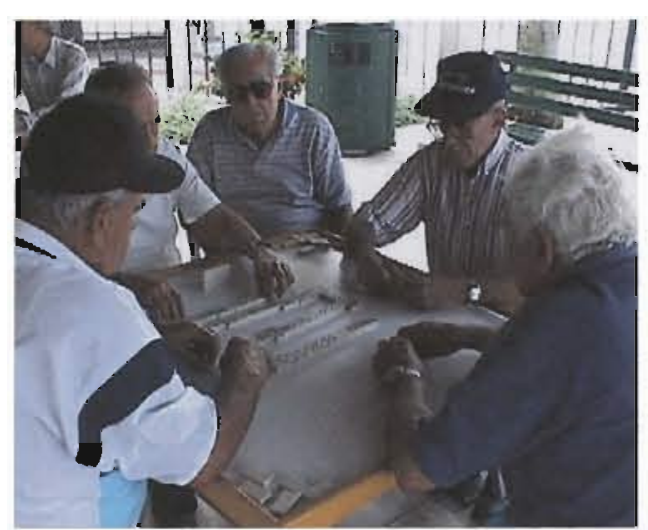

Figure 52. Domino players in the park

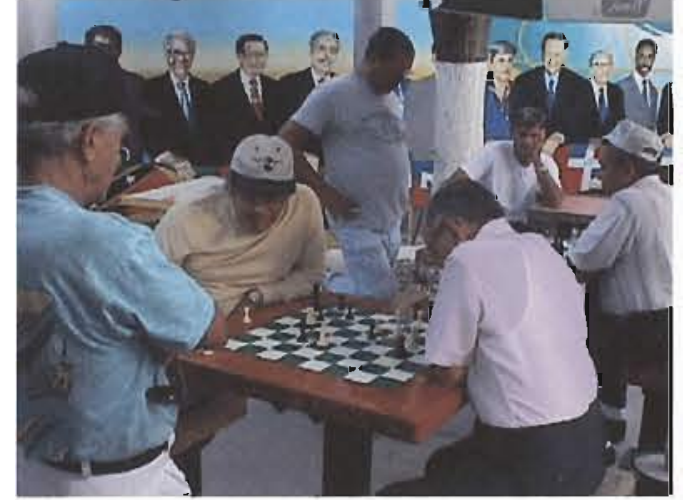

Figure 53. Chess players compete.

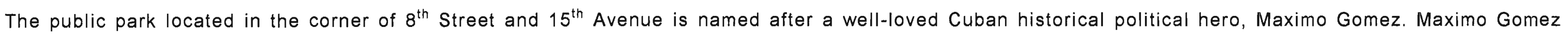

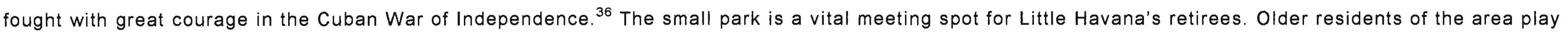

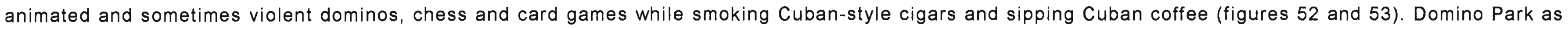
it is informally called, is a focal point on Calle Ocho for the oider residents as well as for the visiting tourist.

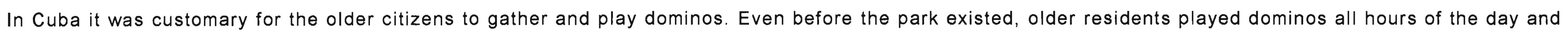

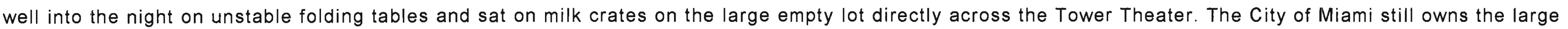

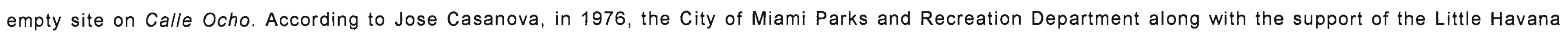
Kiwanas Club bought the property directly to the east of the Tower Theater with the intention of creating a park to promote this activity. 


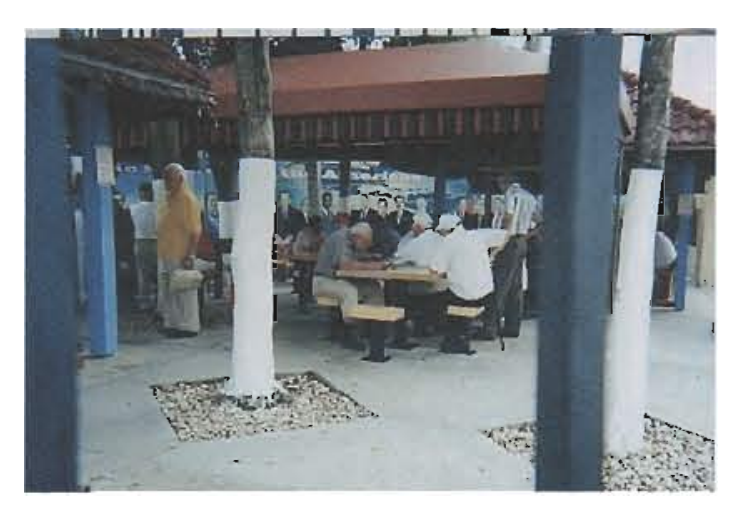

Figure 54. Domino Park.

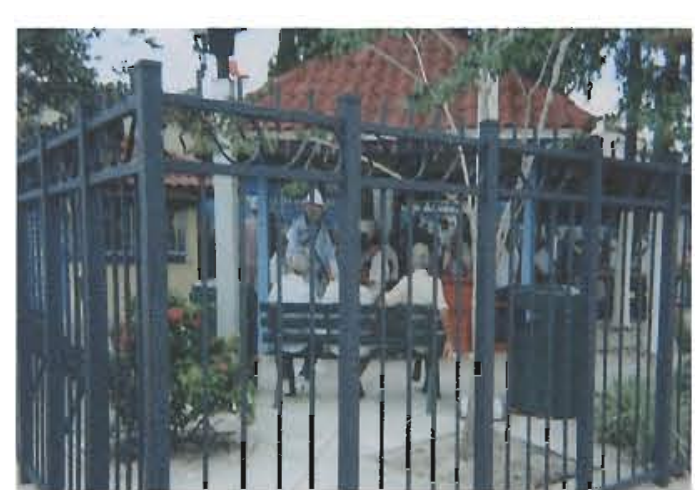

Figure 55. Fenced Domino Park.

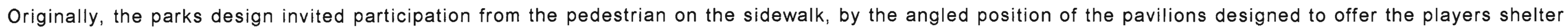

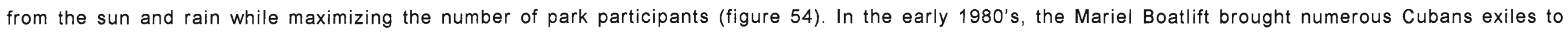

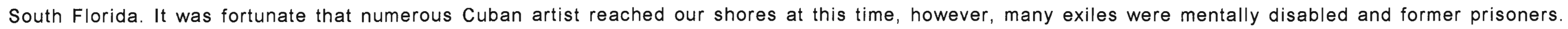

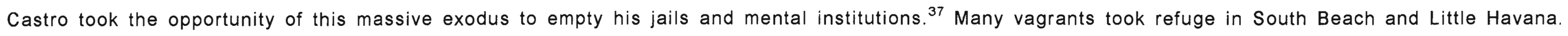

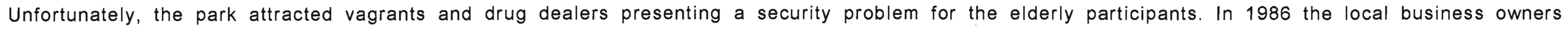

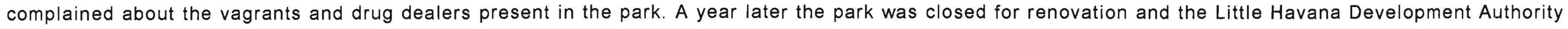

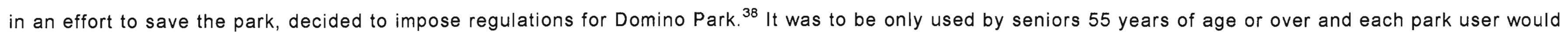

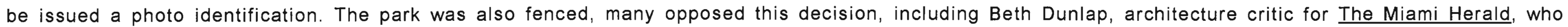

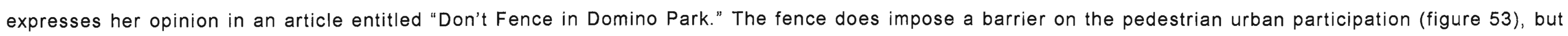

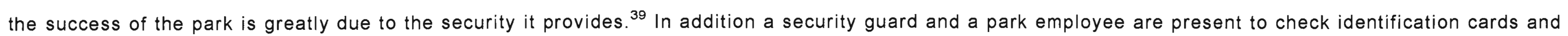
assist the seniors

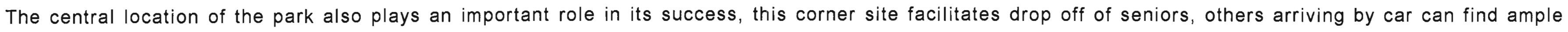

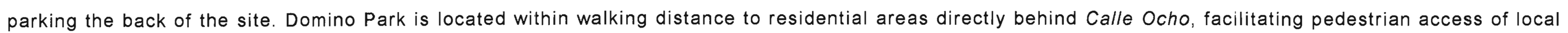




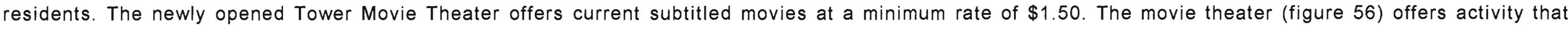
adds further security to the seniors at the park.

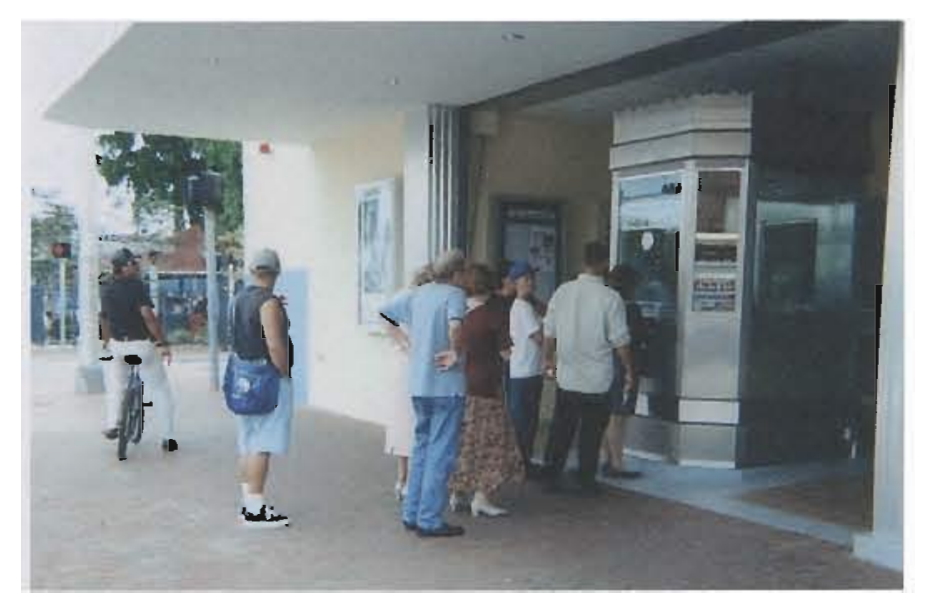

Figure 56. The remodeled Tower Theater next to the park.

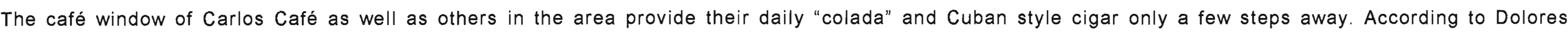

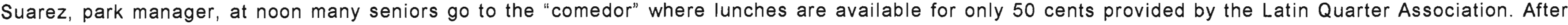

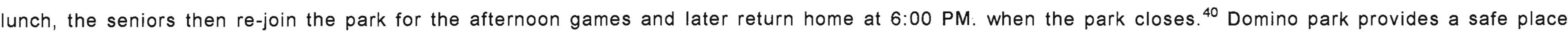
where the senior citizens come to socialize and reminisce about times past.

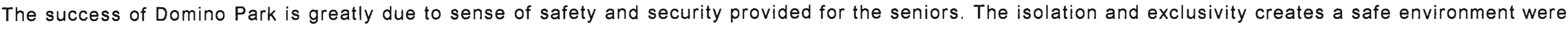

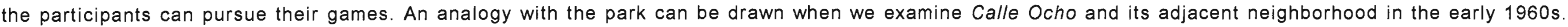

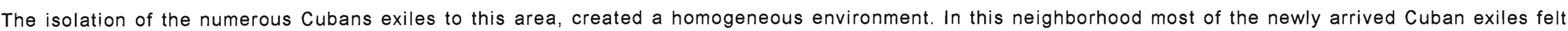

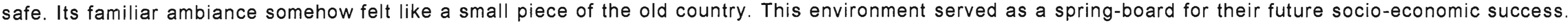
Immigrant neighborhoods can be considered the core of the United States; a country made up of mostly of immigrants groups. 


\section{ENDNOTES:}

1. Rieff, David, 1987. The Second Havana. The New Yorker, 18 May.

2. Flores, Ike. 1975. Miami Bitterness: Cuban Refugees Begin to Feel Discrimination. The Miami News, 3 September.

3. Elder, Rob. 1976. Cubans Look to the Ballot Box. The Miami Herald, 11 January.

4. Johnson, Kathyrn. 1979. Miami: New Hispanic Power Base in U.S. U.S. News and World Report, 19 February.

5. Florida's Polk Directory. 1962. Miami, Florida: R.L. Polk \& Co. Publishers

6. Marx, Linda. 1997. Café Cubano Perfect Cure for Daily Grind. Sun Sentinel, Ft. Lauderdale, FI. 1 July) hppt;//www.sunsentinel.com,

7. Ibid.

8. Rosenberg, Arnie. Life in Little Havana: Baseball Spoken Here. Akron Beacon Journal, Knight-Ridder Newspapers Ohio, IL. 1997 (19 October 1997). http://www.ohio.com/bj/sports

9. Ibid

10. Ponce de Leon, Monica. 1993. Calle Ocho. Places 8, (3): Spring

11. Barry, Bill. 1967. Cubans Dream at the Cafetins. The Miami Herald, 23 August.

12. Benitez, Juan, Vice President of Crown Trading Co. 2000. Interview by author, Miami, September.

13. Reyes, Monolog. 1973. Laundromats and Café Cubano. WTVJ (CBS) Channel 4, December.

14. Ibid.

15. Levine, Robert and Asis, Moises. 2000. Cuban Miami. New Brusnswick: Rutgers University Press.

16. Liebman, Nancy. 1993. Calle Ocho Historic District Concept and Documentation, Miami, Florida: City of Miami.

17. Branch, Karen. 1990. Renown Restaurateur Juan Saizarbitoria. The Miami Herald, 7 July.

18. Arenegui, Santiago, Architect and Professor at Miami-Dade Community College. 2001. Interview by author, Miami, January.

19. Ibid. 
20. Ponce de Leon, Monica. 1993. Calle Ocho. Places 8, (3): Spring

21. Ibid

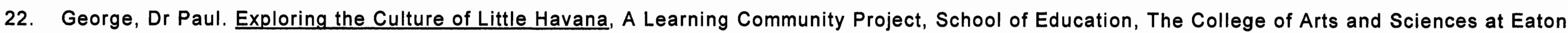

Residential College, University of Miami, http://www.education.miami.edu.

23. Arenegui, Santiago, Architect and Professor at Miami-Dade Community College. 2001. Interview by author, Miami, January.

24. Corzo, Cynthia. 1996. Little Havana Puffs Rings Around the Competition. The Miami Herald, 17 November.

25. Allman, T.D. Miami: City of the Future. 1987. New York: The Atlantic Monthly Press.

26. Soler, Frank. 1969. Our Cuban Exiles make Dade, Florida Sweeter and Smokier. The Miami Herald, 26 October.

27. Levine, Robert and Asis, Moises. 2000. Cuban Miami. New Brusnswick: Rutgers University Press.

28. Lopez-Mata, Gisela. 1987. From Riverside to Little Havana. Cuban Heritage I (Fall 1987)

29. Miller, Gene. 1976. Bay of Pig Banner Returned to Brigade 2506. The Miami Herald, 16 April.

30. Portes, Alejandro, Clark, Juan and Bach, Robert. 1980. Cuban Exiles in the U.S. New York: Arno Press.

31. Slain Exiles Honored. 1961. The Miami Herald, 18 April.

32. Perez, Miguel. 1974. Cubans Observe Independence Day, Demand Liberation Action. The Miami Herald, 27 January.

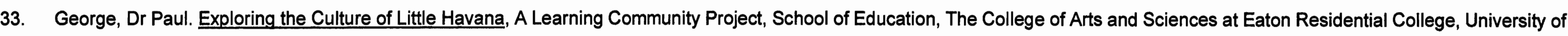
Miami, http://mww.education.miami.edu.

34. Ibid

35. Portier, Richard. 1971. Folk Medicine thrives along the Gold Coast. The Miami Herald, 29 August.

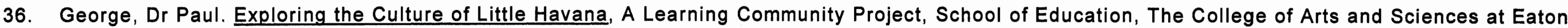
Residential College, University of Miami, http://www.education.miami.edu.

37. Handcock, David. 1998. Decisions Due on Re-opening of Domino Park. The Miami Herald, 18 February.

38. Suarez, Dolores, Manager of Domino Park. 2000. Interview by author, Miami, October. 
39. Dunlap, Beth. 1987. Don't Fence in Domino Park. The Miami Herald, 16 November.

40. Suarez, Dolores, Manager of Domino Park. 2000. Interview by author, Miami, October. 


\section{CHAPTER 5:}

\section{CUBAN ETHNIC IDENTITY}

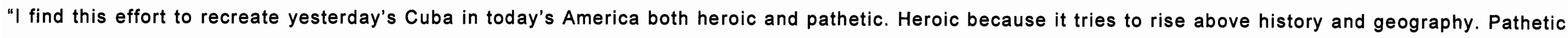
because it is doomed to fail." 1 Gustavo Perez Firmat

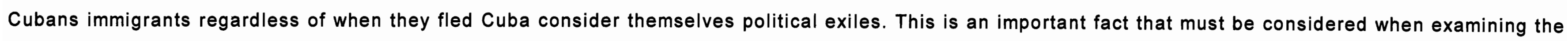

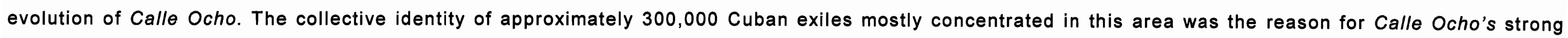
ethnic identity. ${ }^{2}$

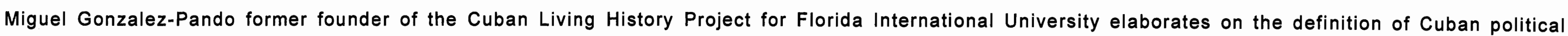

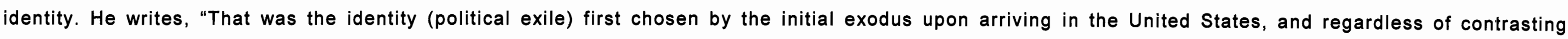

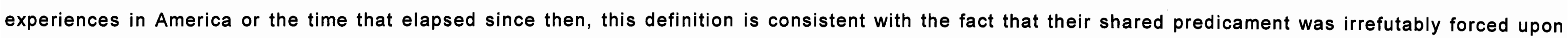

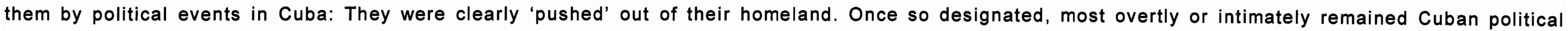

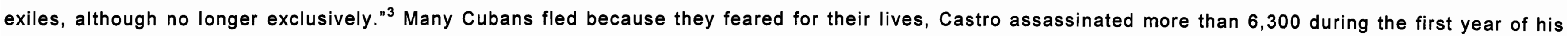
regime. ${ }^{4}$

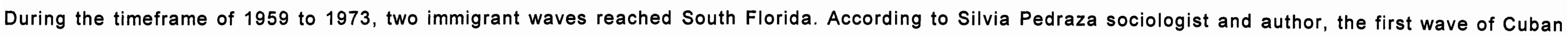

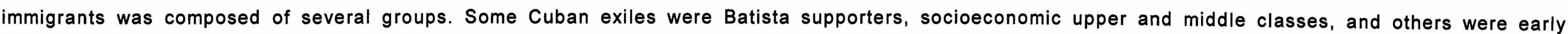




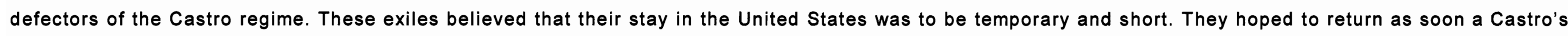

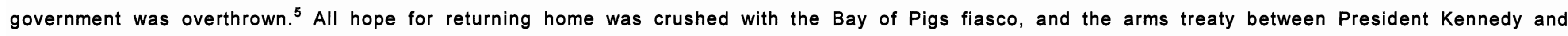

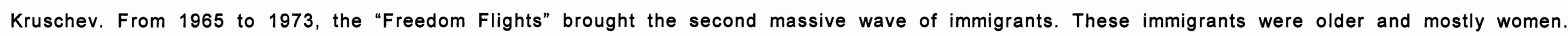
Consequently, at the end of 1973, approximately half-a-million Cubans were living in the United States. ${ }^{6}$

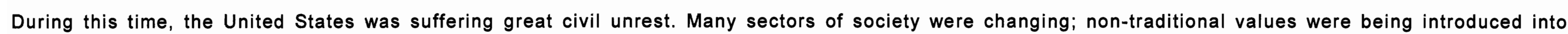

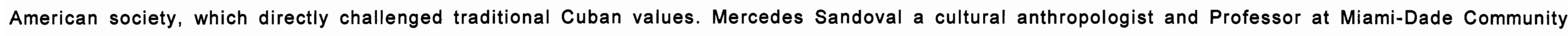

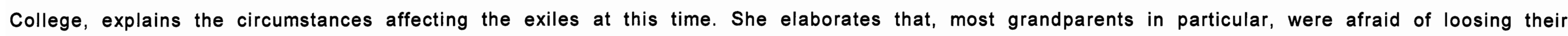

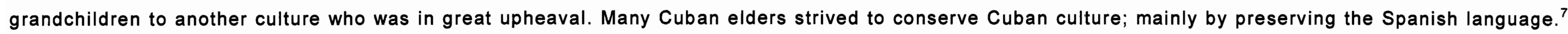

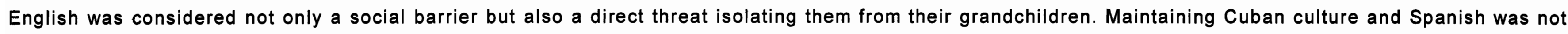
difficult because many exiles segregated themselves in the area of Little Havana.

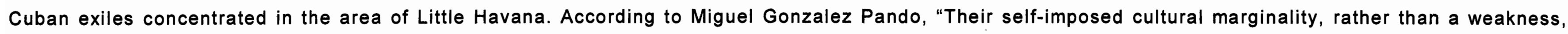

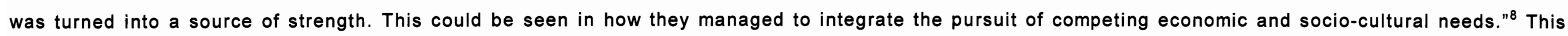

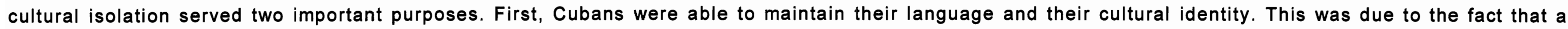

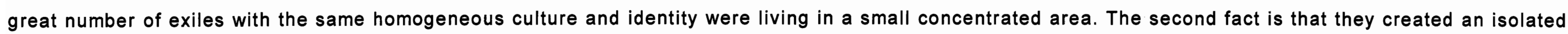
market within their own culture.

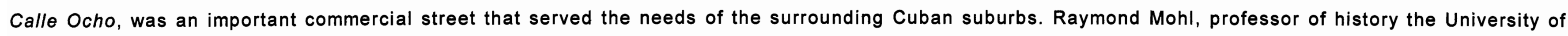

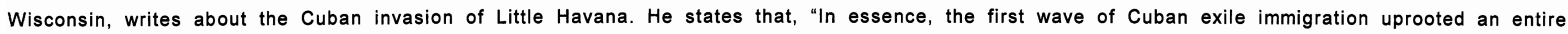

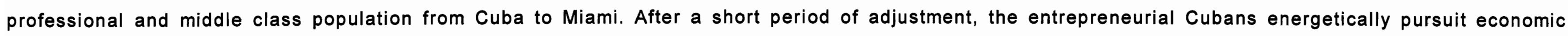




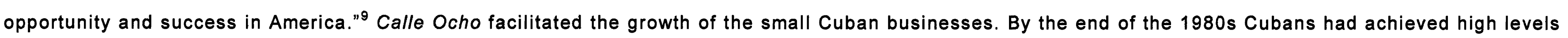
positions in cultural and institutional life as well as an economic base of 25,000 businesses. ${ }^{10}$

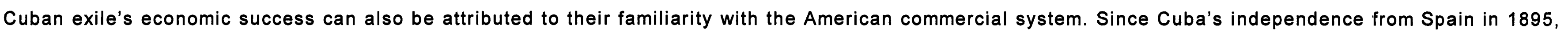

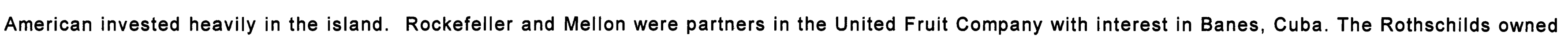

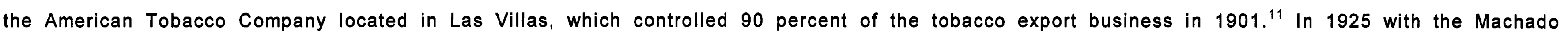

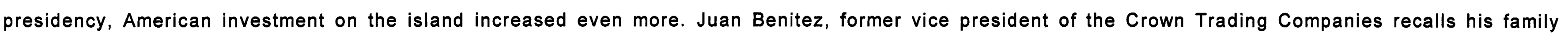

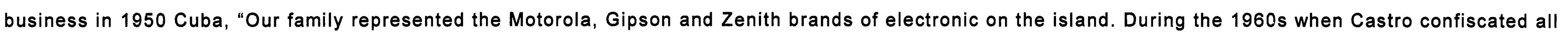

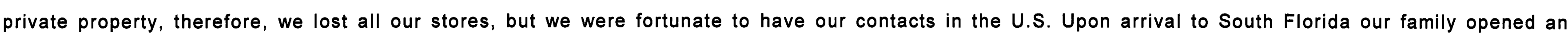

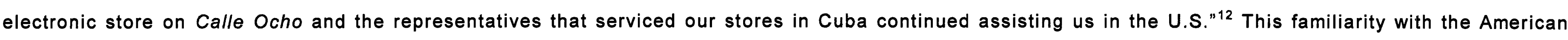

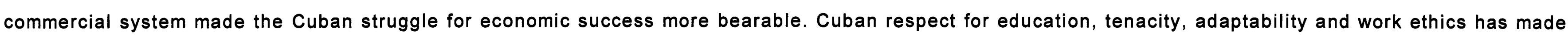

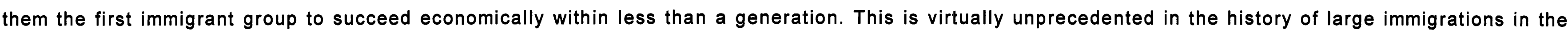

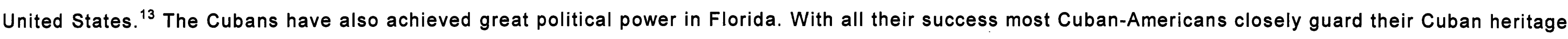
and continue to consider themselves political exiles.

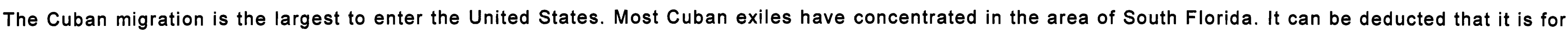
this reason most Cubans exiles maintain their ethnic identity. 


\section{ENDNOTES:}

1. Perez Firmat, Gustavo. 1994. Life-on-the Hyphen: The Cuban-American Way. Austin: University of Texas Press.

2. Jacoby, Susan. 1974. Miami Si, Cuba No. The New York Times Magazine, 29 September.

3. Gonzalez-Pando, Miguel. 1998. The Cuban-Americans. Westport, Connecticut: Greenwood Press.

4. Ibid.

5. Pedraza, Silvia and Rumbaut, Ruben G. 1996. Origins and Destinies: Immigrations, Race, and Ethnicity in America. Belmont: Wadsworth.

6. Cruz, Humberto and Douthart, Bill. 1975. Cubans to Gain Number, Power. The Miami News, 2 May.

7. Gonzalez-Pando, Miguel. 1998. The Cuban-Americans. Westport, Connecticut: Greenwood Press.

8. Ibid.

9. Mohl, Raymond. 1990. Searching for the Sunbelt: Historical Perspective on a Region. Knoxville: The University of Tennessee Press.

10. Jacoby, Susan. 1969. Havana, Florida. Newsweek. 7 September.

11. Presidents of Cuba. 2000. Carnegie Mellon University, Lycos Inc. http:// www.angelfire.com.

12. Benitez, Juan, Vice President of Crown Trading Co. 2000. Interview by author, Miami, September.

13. Jacoby, Susan. 1974. Miami Si, Cuba No. The New York Times Magazine. 29 September. 


\section{CHAPTER 6:}

\section{PROPERTY HISTORY ON CALLE OCHO}

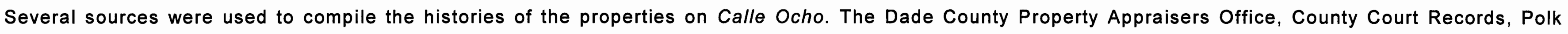
Index, Nancy Libman's Calle Ocho Historic Concept and Documentation prepared for the City of Miami in 1993 as well as numerous sites visits.

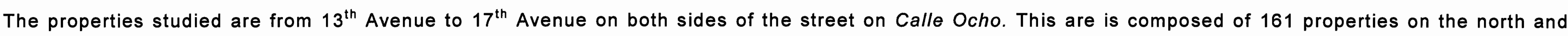

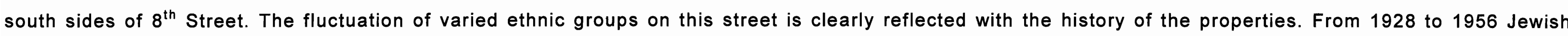

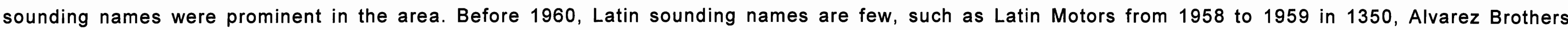

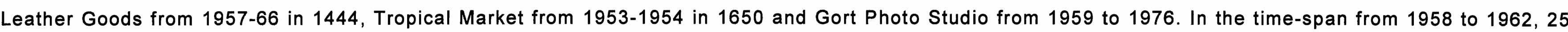

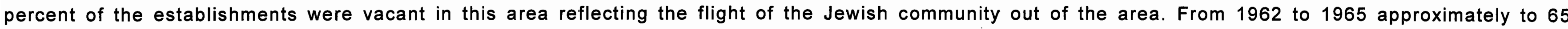
percent of the establishment had Spanish sounding names.

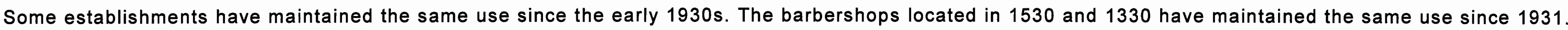
El Oriental Chinese Restaurant has been in operation since 1949.

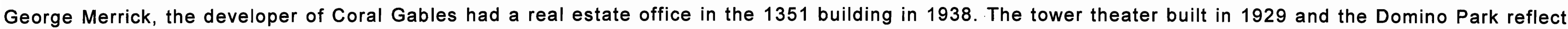
two different layers on this historical street. 


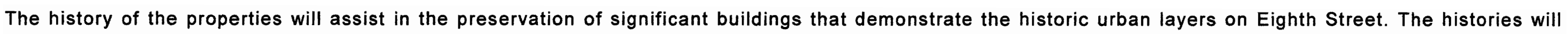
also indicate establishments with the same use since its initial tenant; Jewish in the 1930s and then Cuban in the 1960 s. 


\section{South Even Numbers}

$13^{\text {TH }}$ AVENUE:

$1302,04,30,34,36$

BUILT: 1930

OWNER:

TENANTS:

1302

1931 Kraft Barney Grocery 1931-000 not listed

1304

1933 Goldstein Jacob Grocery

1934 Juicy Fruit Curb Market

1935 Indian River Curb Market 1330 *

1949 Carl \& Author Barbers

1953-60 Eddie's Barber

1962-74 El Arte Barber

2000 Barber Shop

$1334^{*}$

1937-57 Indian River Fruit and meat Market

1958-59 Indian River Fruit and Klien-Weiss Meat

Market

1960-70 Destroyed by fire

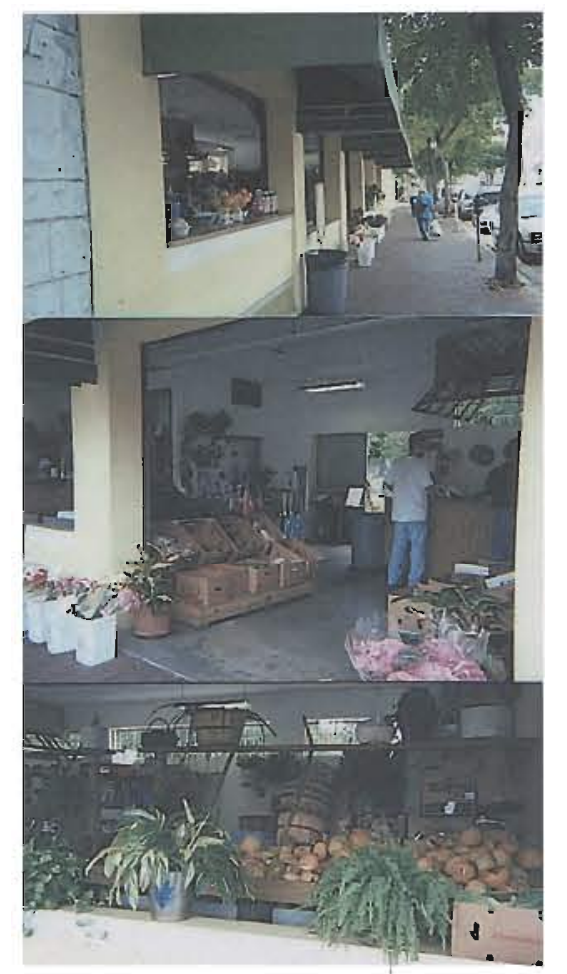

Figure a. 1304.
1971-00 Los Pinarenos

1336

1949-53 Curb Lunch

1956-60 Laundry Basket

1964-72 El Sitio Restaurant

1973 Cojimar Restaurant

1074-76 El Dragon Restaurant

2000 Los Pinarenos

* Note: 1330 has been a barbershop since 1949 and 1334 has been a fruit market since 1937.

$1340,44$.

BUILT: 1930 addition 1964, 1970.

OWNER: Optica Lopez Inc.

TENANTS:

$1340 *$

1933-34 Certified Poultry \& Egg

1935-59 Tennessee Poultry Co.

1960 vacant

1962-64 OFA Paint \& Body

1966-69 Tropiburger

1970-00 Optica Lopez

1344

1937 Silver Tower Restaurant

1940-44 William Electric Contractors

1945-47 Christie Restaurant

1949 vacant

Note: The Lopez, A Cuban family, on $8^{\text {th }}$ street since 1966 originally in 1603 SW $8^{\text {TH }}$

Street, later purchased the $1340-44$ building.

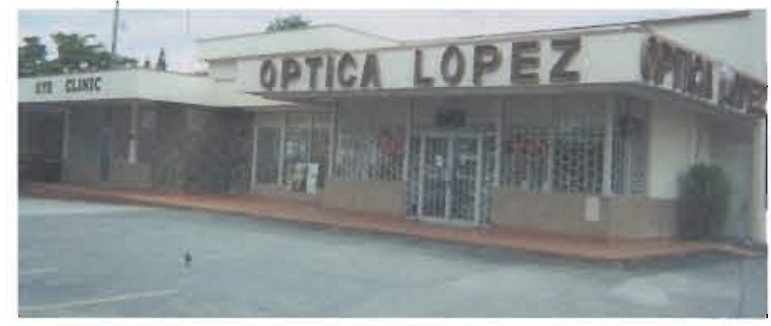

Figure b. 1340-44. 
$1350,56,58$.

BUILT: 1949

OWNER: Julio V. Arango

TENANTS:

$1350^{*}$

1949-50 BW Motors

1953 Select Motors

1956 Sprawling Motors

1957 Daves Quality Motors

1958-59 Latin Motors

1960 Oscar Motors

1962 Miami Motors

1964 Havana Miami Inc.

1966-73 La Caridad Coffee Shop

*Note: Latin Motors in 1958-59 the area must have had Cubans that were fairly wealthy or larger population to support this business.

1356-58

1970-72 La Canastilla

1976- Farmacia Havana

2000 Karmen Bakery

1360,62 .

BUILT: 1953

OWNER: Stahls Realty Corp.

TENANTS:

$* 1360$

1953-76 Stahls Meats

1977-93 Casa Sierra

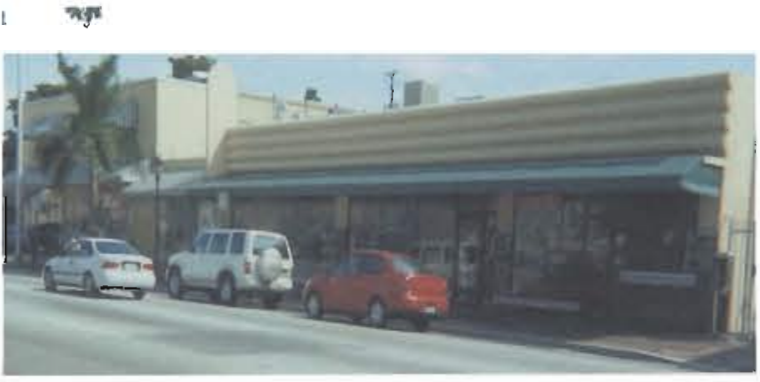

2000 vacant

1362

1953-56 Esquire Deli.

1976 La Caridad Coffee Shop

*Note: the owners of the building are still Jewish that owned a Meat Market in 1953

76. This structure has housed a meat market since 1953.
1380

BUILT: 1941 additions 1957, 1963, 1967

OWNER: Francesca and Juan Calvo

Trustees

TENANTS

1380

1940 Glen Filling Station

1941 Edward's Filling Station

1953-57 Puritan Dairy 1934

Margaret Allen

1959 Arcorn Cleaners

1960-69 La Plaza Super Market

1970-00 Colon Super Market

1388, 90

BUILT: 1925

*OWNER: Bernard Hershkowitz

1388

1937 Arlington Real Estate

1938 vacant

1939 Garnett Barber

1940-41 Frank Turner Baths

1942 vacant

1947-49 Nearly New Antique Shop

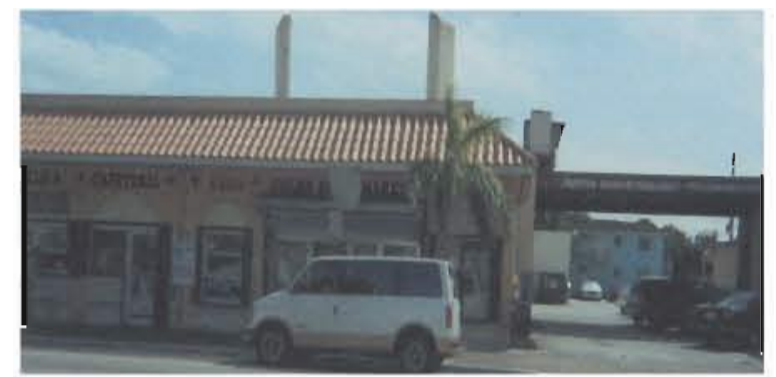

Figure e. 1380.

2000 Bargain Discou

1390

1934 Arnold Manufacturing

1935-42 Ace Dry Cleaners

*Note: Current owner has Jewish ethic sounding name. In 1993 used to be a

tourist stop for buses in Calle Ocho. The market attracted tourist from all over the

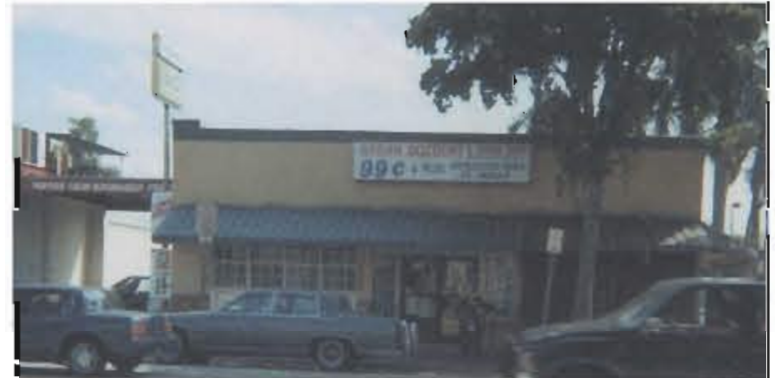

Figure f. 1388-90.
1953-72 Arrow Cash \& Carry Cleaners

1993 Calle Ocho Market

2000 Nena's Laundry

world. Today it is a laundry that looks run down.

Figure d. 1360. 


\section{$14^{\text {th }}$ AVENUE:}

\section{*1400,02,08, 10}

BUILT: 1985

OWNER: Mc Donald Corp.

TENANTS:

1400

1940 Smith Filling Station Orr Minivan

1941 Brannon Service

1942 Campbell Motor Inn

1947-49 Charles Loss

1949-62 Tower Filling Station

1964-71 Luaces Service Emil Jim

1972 Infante BP

198300 Mc Donalds

*Note: Fast Food restaurants threaten the ethnic environment of the area.
$1412,14,16,20,22$

BUILT: 1973 vacant lot

OWNER: Latin Quarter Center

TENANTS:

1422

1949 Tower Furniture

1957-59 New Look Breakfast Nook

1960 vacant

1969-72 Casa Capo Furniture

1976 Ulysis Furniture

1983 Vacant lot

$1438,40,42$

BUILT: 1919

OWNER: Aurelio Rodriguez

TENANTS:

1440

1925 Eli Darlow

1926-41 Peter Vanbeck

1933-38 John Clolozoff

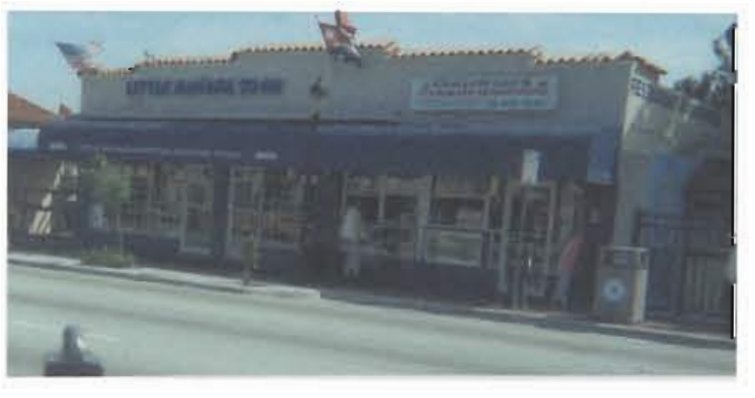

Figure g. 1438-24.
1942 vacant

1953-60 Harry Hovsenian

1962 Pedro Aleman

1964-72 Maria Rodriguez

1976 vacant

*2000 Little Havana to go

Note: The building is very well renovated. This particular store is newly renovated and well designed.

1442

(940-42 Riverside Laundry

1947 Real Estate

1949-53 Lawrence Fienburg

1956 Central Carpet

1957 Adele Dental Lav.

1959-72 vacant

2000 Carlos Cafe

$1444,46,54$.

BUILT: 1988 Domino Park

OWNER: City of Miami

TENANTS:

1444

1931-33 Emma Bil

Restaurant

1957-66 Alvarez Brothers

Leather Goods

1962-66 El Goza Bakery

1966-76 Perzsosa Bakery

1988-00 Maximo Gomez Parkl Domino Park

*Note: Domino Park is a focal point for seniors and tourist on Calle Ocho.

\section{$15^{\text {TH }}$ AVENUE:}

1500,08

BUILT: 1926

OWNER: City of Miami

TENANTS:

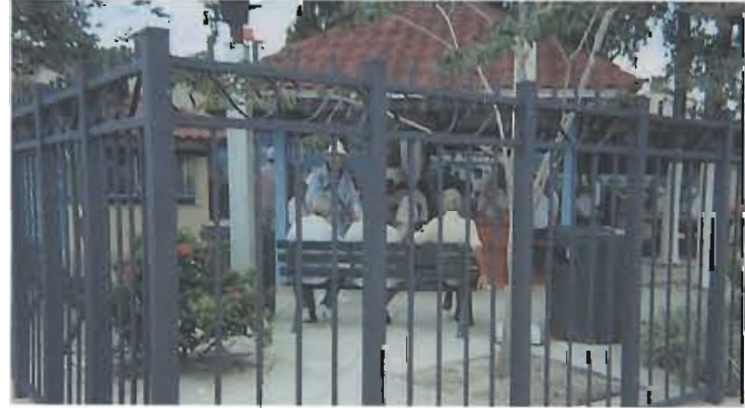

Figure h. 1444-54.

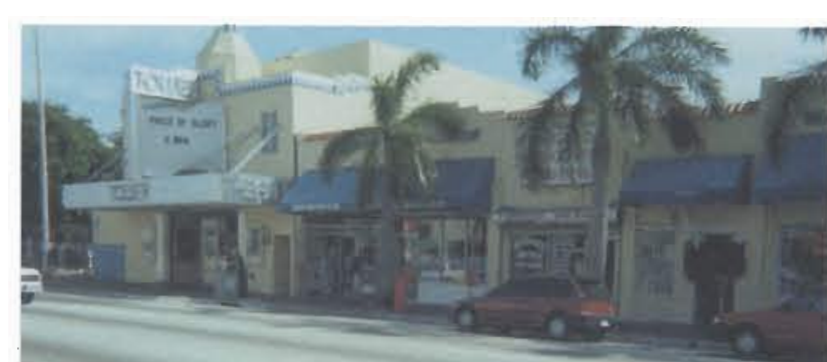

Figure i. 1500-08. 
1500-08

1929-31 Tower Theater Smith Contractors

1933-37 Smith Contractors

1938-39 Landis Contractors

1940-42 Rodney Contractors

1957-73 Tower Theater

1992-00 Tower Theater

$1510,12,14,16,161 / 2,18$

BUILT: 1926

OWNER: Avigdor Landman

TENANTS:

1510

1931 Rene Smith Dresses John Solomon Filing Station

1933 vacant

1934-66 Tower Sundries Drugs

1967 Los Cubanos de Goya

1967-00 El Esquisito Restaurant

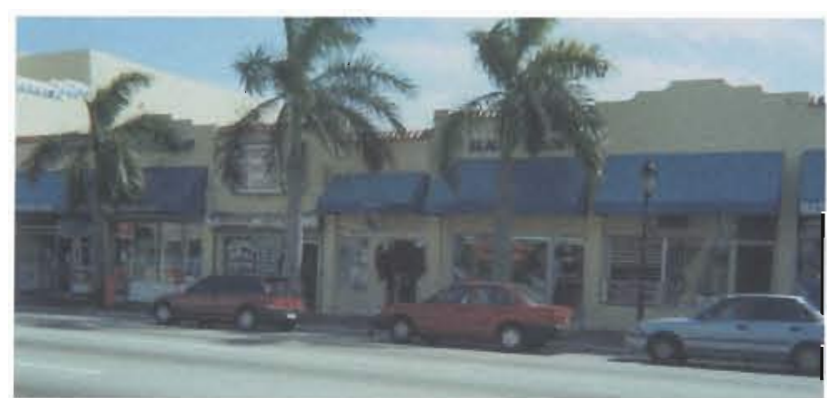

Figure j. 1510-18.

Note: The owner of El Esquisito Restaurant has been in the same location from 1967 to present. In 1990 he opened the Pub Restaurant formally Badias Restaurant Badias had been Felipe Vall's restaurant from 1965 to 1990.

1512

931-33 Mason \& Davenport Real Estate

1934 Karnes Realty Service

1935 Earl Coffin Real Estate

1937-38 Levy Dresses

1939-49 Jones Dentist

1953-56 Seymour Chiro.

1960-62 Bradley Finance

1964-76 Eagle Finance

1514

983-00 Gold Touch Shop

1931 Walter Bantz Contractor

1933 vacant

1934-37 White Radio Service

1938 Jack Babroff

1940 Mullen Electric

1941-41 Good Housekeeping Electric Equipment

1947-49 Rae's Dress Shop

1953 Diehls Women's Wear
1956-57 Kathleen's Inc.

1959-60 vacant

1962-70 Tower Clothes

1516

1937 Benjamin Shannon

1938-40 White Radio Repair

1941-42 Charles B. fine Watch Repai

1947 Pierce Watch Repair

1949 Corner's Gift Shop

1953-66 Trace Jewelers

1967-000 La Milagrosa

1518

1931 vacant

1933-34 Cheney Barber

1935 Francis Redmond Decorato

1937 Tower Haberdashery

1938 vacant

1939 Reader Jewel.

1940-42 Marvin Barber

1947-66 Mademoiselle Beauty Salon

1967-72 Vivettes Modas

1976 Caron Beauty Salon

1993 Mirian \& Dionisio Beauty Salon

2000 Dionisio Beauty Salon

$1520,22.28,30,32$.

BUILT: 1927

OWNER: Felipe Valls

TENANTS

1520

1931 Sedon Cleanres

1931 Perfect Cleaners

1934 vacant

1935 Bean \& Salad Shop

1937-38 The Dutch Kitchen

1939-41 French Restaurant

1942 Rene's Restaurant

1947 Newton's Hobby Shop

1949-59 Trail Hobby Shop

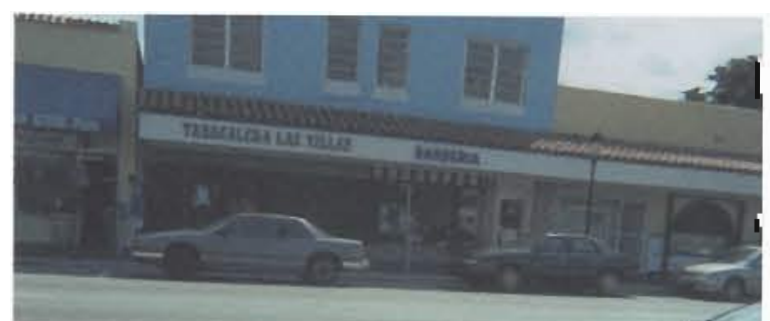

Figure k. 1520-32 
1962-93 Mi Botica Farmacia

1999-00 Tintoreria Lucy

1522

1931 Navajo Rugs

1933 Acacla Flower Shop

1934-35 Tower Photo

1937 Max Moss Shoe Repair

1938-40 Bennett Children Wear

1942Summers Music Shop

1947-62 Kaal Music

1964-76 Ultra Records

2000 Martinez \$ Store

1528

1934-42Bosh Electric

1947-49 Melrose Electric

1953-57 Trail Hobby

1959 London Dress Manuf.

1960 Alvarez Bros. Hangbags

1962-64 International Reptiles

1966-76 Monte Carlo Shoes

1998-00 Tabaqueria Las Villas

1530

1931 Dillard's Barber

1933-47 Covert Barber

1953-76 Eighth Street Barber

2000 Barber Shop

Note: This property has been a barbershop since 1929 to present

1532

1935 E. Hecker

1937 Bell Photo.

1938 vacant

1939 O'Neil Phy.

1940-41 vacant

1941 Mrs. Sprigging

1947-49 Pruder Nurse

1953-64 Myrtle Hayes Furn. Rooms

2000 Latin Quarter Association
$1534,38,42,48$.

BUILT: 1933

OWNER: Felipe Valls

TENANTS:

1534

1931 Smart Dress Shop

1933-35 Miami Laundry

1937-49 White Chiro.

1956-60 Berkholder Chiro.

1962 Ross Chiro.

1964-69 Quiroga Jewelry

1970-72 Sorrento Jewelry

1976 Isis Jewelry

1977-00 Nevada Jewelry

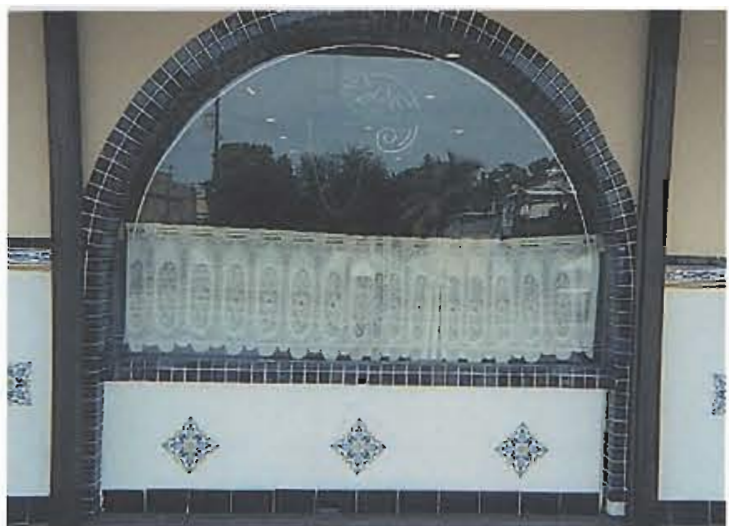

1538

1941 Mary Lou Beauty Salon

1942-62 Trail Beauty Shop

1964-66 Maria Antonia Beauty Salon

1542

1967-72 Caron Beauty Salon

1941-53 Barnetts Juvenile Shop

1956-57 Tower Juvenile Shop

1959 Trail Happy Shop

1962-66 Television Center

1967-72 Badias Dining Room

1548

1931 Patterson Restaurant

1933 Pat's Lunch Restaurant

1934 The Keg Saloon

1937 Miller Brothers Contractors

1938 Blumenbach Sales

1939 Trail Press

1940-41 Glucker \& Morrison

1942 Glucker Cleaners

1947 Thomas Hart Business

1964 El Meson Restaurant

1966-90 Badias Restaurant

1992-00 EI Pub Restaurant

Note Felipe Valls arrived from Cuba in 1960. In 1965 he opened Badias and

operated it from 1965 to 1990 . Today he owns a chain of restaurants called La Carreta and several other restaurants.
Figure I. 1548 
$1600,02,04,06,08,10,12$

BUILT: 1949

*OWNER: Louis Leibowitz Trustee

TENANTS:

1600

1931 Killian Soft Drinks

1934 Thompson Restaurant

1935-37 El Dragon Restaurant

1938-39 Dolly Madison Ice Cream

1600

1940-49 Puritan Stores

1953-60 Factory Outlet Floor Covering

1962 vacant

1964 Trail Stationary

1966 vacant

1967 Crown Trading Co.

1970-76 Color Sewing Machine Center

1993 Guarina Cafeteria

*2000 Diana's Antiques

1602

1940-56 vacant

1957 International Photo

*1959-76 Gort Photo

1604

1953-56 Rainbow Shops 1957-64 Snyder Realtor 1969-76 Mi Novia Clothes

1606

1953-62 European Photo.

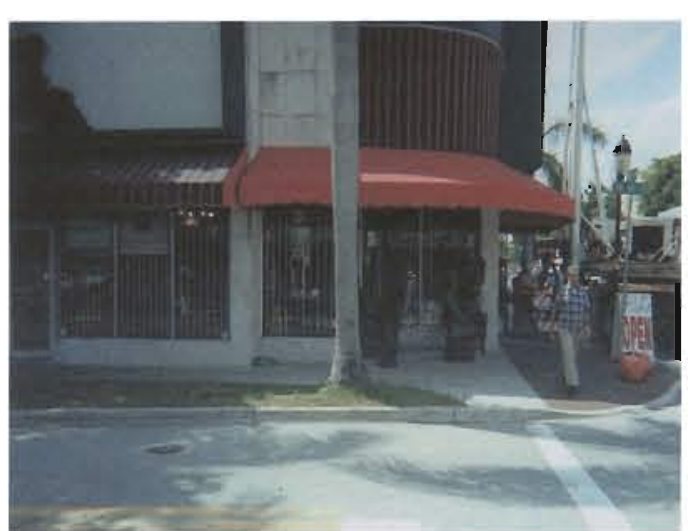

Figure m. 1600.

1964-67 Refrigerator Center 1969-76 El Sol Men's Clothes

1608

1953-62 Trail Stationary

1610 1964-00 Marina's Beauty Salon

1947 Siger Real Estate

1949 Southwest Realty

1953-59 Miami Art Upholstery

1960-62 Trail Shoes

1964 vacant

1966-71 Maruchi Bakery

1972-76 Valdez Fauli Pastry Shop

1993 Bodeguita del Medio

1612

1999-00 El Buen Savor

1953 vacant

1956 Dial's Pint

1957-66 Jack's Barber Shop

1967-76 Eliseo \& Nene's Barber Shop

1999-00- Nene Barber Shop

Note: The building is owned by ethnic Jewish sounding name. Diana's Gallery is owned by an American part of the new artist migration. The Gort family established their photo studio in Calle Ocho in 1959. They have relocated to Coral Gables in 1976.

1616,18

BUILT: 1937

OWNER: Mary \& Anne Berk

TENANTS:

1616

1956-67 Roth Chrome \& Iron Works

1618 1976 El Canonazo Furniture

1938-53 Darmen Auto

1956-57 GFC Loan Com

1959-60 Best Industries Typewriters

1962-72 Chrome Furniture Showroom 
Note: The owner has Jewish ethnic sounding name, they own 1616/18, 1620/34, $1638 / 40$, and $1601 / 11$ on $8^{\text {th }}$ Street.

\section{$1620,28,30,34$.}

BUILT: 1947 additions $1947 \& 78$

OWNER: Mary \& Anne Berk

TENANTS:

1620

1937 Darmen Garage Storage

1938-46 Sam Cline

1947 vacant

1953-70 Royal Castle

1971 Fritas Cubanas

1976 El Bocadito

1993-00 Casa Panza Restaurant (1622)

1630

1957 vacant

1634

1959-62 Mosier \& Son Storage

1947

1953

1960 vacant

1969-76 Mario's Jewelers

$1638,40$.

BUILT: 1935 additions 1945

OWNER: Anne Berk

TENANTS:

1638

1937-73 Moser \& Son Real Estate 1999-00 Pio V Cigars

1640

1939 Miami Laundry

1972-73 not listed

2000 Cigar Manufacturer

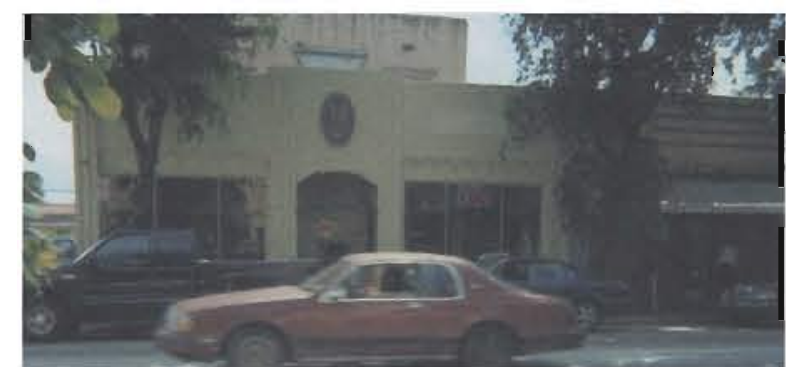

Figure 0. 1620.

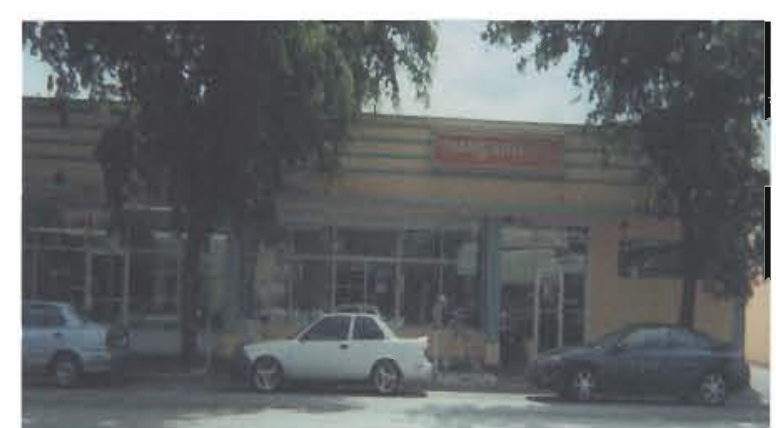

Figure p. 1638-40.

Sarasota to without cultural variety. This is how he meet his wife and got in the business. The building is completely remodeled

$1642,44.46,48$.

BUILT: 1946

*OWNER: Sam Chao \& Jean Pac

TENANTS

1642

1949-2000 Oriental Restaurant

1644

1933-35 Brown Birds

1937-42 Shenandoah Bird Shop

1947 House of Morgan Electric

1949-60 Atlantic Services

1962-64 Jose Solis Novelties

1966 vacant

1967-69 Ricky's Floor Covering

1971 vacant

1976 Stop Fabric Corp

1646

1993-00

1948Arno's Shoes

1953-59 Trail Shoes

1960-62 vacant

1964-76 Chantres Fares

Cleaners (1648)

1648

1947-53 Center Cleaners

1993 Star Furniture

2000 Transouth

*Note 1642 has been a Chinese Restaurant since 1949 and same owners.

Note: There are two cigar manufacturers in this building. One is an American married to a Central American woman who was already in the cigar business. He is an artist

from New York. He later moved to Sarasota, he often visited Miami because he found 
1648

1947-53 Center Cleaners

1993 Star Furniture

2000-01 Transouth Corp.

$1650,52.54$.

BUILT: 1926 /1948 addition

OWNER: Reca Inc.

TENANTS:

1650

1947Family Finance

1953 Tropical Market

1956 Lewis \& Son

1960-64 Glass Palace Frames

1964-76 U. S. Jewel.

1993 Surprise Jewel.

1652

1949 Economy Cash \& Carry

1953-56 Sac's Barber

1959 Hollywood Barber Shop

1969-71 U.S. Investments \& Sales

1972 U. S. Jewel

1976 Balmoral Jewel.

1993 Rosales Jewel.

1654

1948Daniel Kinder

1953 vacant

1956-69 Norman Gadsden Phy.

1971-76 La Venecia Picture Frames

1993 vacant
$1668,72,74$.

BUILT: 1945

OWNER: Mechoso Store Inc.

TENANTS:

1668

1947 Diamond

1949 Garnitz Furniture

1949 E. Mikell

1953 vacant

1956 Harles Littlefield

1959-64 Lawrence

1966 Miguel Membrado

1967-71 Rolando Garcia

1971 Carlos Fojo

1972 Marian Martin

1972 Orlando Garcia

1973-00 Mechoso Store

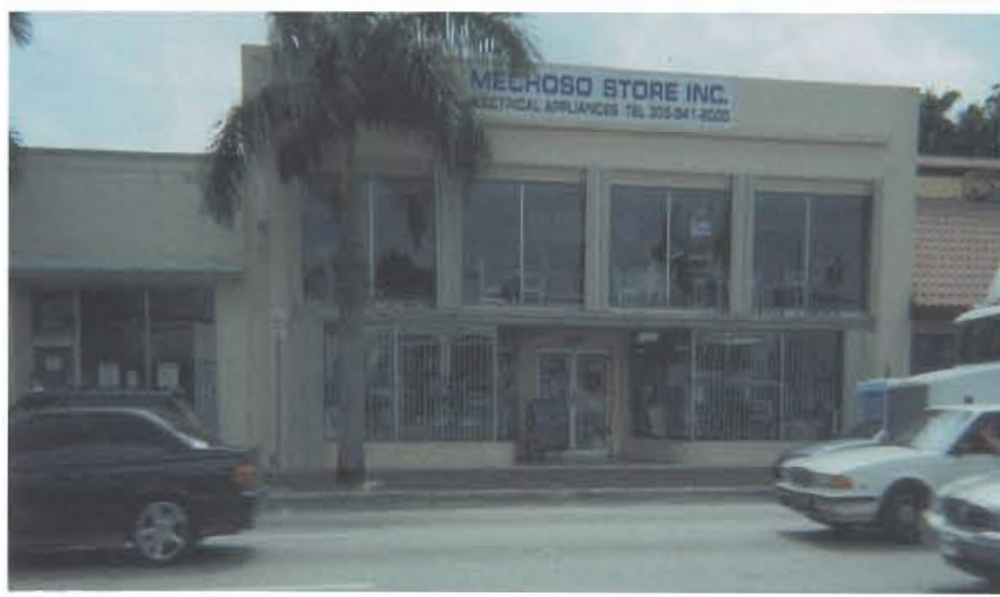

Figure q. 1688-74 
$1676,78,80,88,90,92,94,96,98$.

BUILT: 1982 (other buildings on site since 1930)

OWNER: Grapefruit Corp.

TENANTS:

1676

1935-49 F, N. Holly 5\&10 Cent Store

1953 vacant

1959-62 Sam the China Man

1993 Monica

1678

1953-56 vacant

1959-62 Sam the China Man

1964-72 G\& L Importers

1993 vacant

1680

1933-35 Fashion Dry Cleaners

1688

1928-35 Piggly Wiggly

1690

1937-42 Shenandoah Groceries

1947 National Delicatessen

1949Trail Inn Restaurant

1953-66 Community Finance

1967 Interiors Furniture Storage

1969 Copa Importers

1970-72 vacant

1692

1993 Potin Restaurant

1928 Helmans Cleaners

1931-42 Economy Cash\& Carry

1947-56 Osle Crowder Woman's Furnishings

1966 vacant

1969-71 vacant

1993 Potin Restaurant

1694

1931 Harvey Contractors

1933 vacant

1934 Goldstroms Bakery

1935 Elizabeth's Shop

1938-56 Osle Crowder Woman's Furnishings

1957-62 Models Family Apparel

1993 Ambar Pyramids
1698

1928 vacant

1929 Otto Bernard Drugs

1931-42 Brooks Drugs

1947-49 War field's Drug

1953-64 Green Drugs

1966-72 Havana Drugs

1993 Frank Joyeria 


\section{North Odd Numbers}

\section{$13^{\text {TH }}$ AVENUE:}

1305

BUILT: 1949

OWNER: Sunflag Ltd/1993

TENANTS:

1940-Trail Pontiac

1956- Hudson Trail Motors

1957-vacant

1958-1973- Goodyear Service

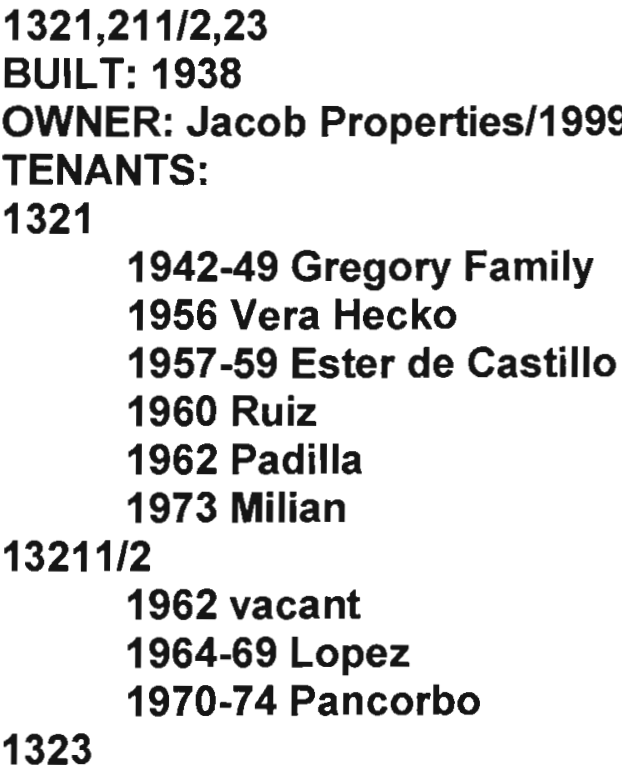

1938-41 John Cagey Realtor

1942 vacant

1953-62 John Kirton Chiropractor

1964-76 Merit Trading

1976-00 Happy Store

1325,27,29, 291/2

BUILT: 1940

OWNER: Jacob Properties/1999

TENANTS:

1325

1942 Donald Holland

1945-47 Robert Power

1949 William Unke

1953 Tony Tonias

1956 Roberto Rodriguez

1958-60 Nicholas Petropoulos

1964-66 vacant

1967 Gloria Gonzalez

1969-71 vacant

1972-76 Anolio Suarez

1976 -00 Happy Store

1327

1939-42 Margaret Beauty Shop 1945-67 Hollywood Beauty Shop

1969-76 Martha Beauty Shop

1976-00 Manny Unisex

1329

1940 Sunny Electric Contractors 1941 vacant

1942 Clarence Sunlighter

1945-47 Mrs. Coreen Storm

1949 Otto Simpson

1953-59 Carmen Fernandez

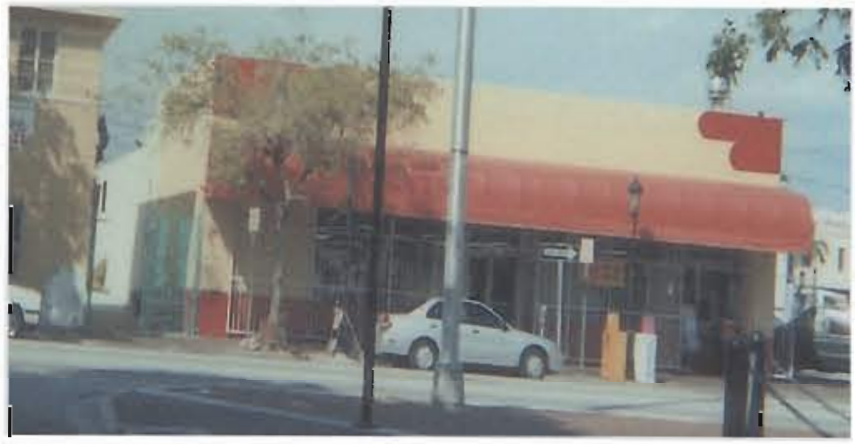

Figure r. 1325. 


\section{$1331,33,35,41,411 / 2$}

BUILT: 1956

OWNER: Villablanca Investments Inc. TENANTS

1331

1953-66 Star Printing Service 1967-72 vacant

1973 Maison Darling

2000 Antiguedades Cubanas

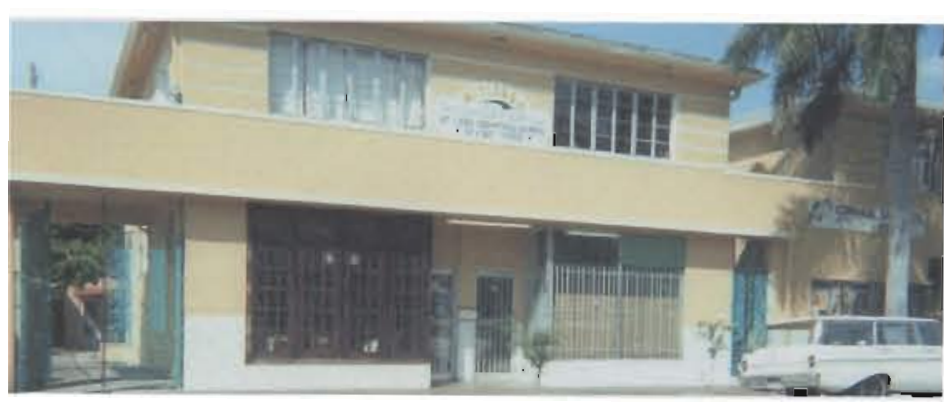

Figure s. 1331.
1333

1957 Jepeway Real Estate

1958-59 vacant

1960-61 Tip Top Radio

1962 vacant

1964-70 The Children's Store

1335

1971-00 Meson Darling

1956-57 Allison Albert

1958-0 Apartments

1341

1942-47 Harry Higgens Air-conditioning

1953 Amede Gagne

1956 vacant

1957-73 Tony and Dick Auto Service

Note: Ben Wolcott, artist specializing in music and jewelry design. He moved his studio and residence from Miami Beach 5 months ago (May 2,000). He lives in an apartment/ studio above the new antique store that also recently moved in. The

owner according to Wolcott, is hoping to attract more artist to live in his property.

\section{TENANTS:}

1343

1927-29 vacant

1931 William McGee

1933 Hannah Bowels

1934 Margaret Allen

1935 Reuben Williamson

1940 George Rock

1949-69 Ritcher Custom

Upholstery

1970- 76 Gonzalez Upholstery

1976-00 Casa De Los Trucos

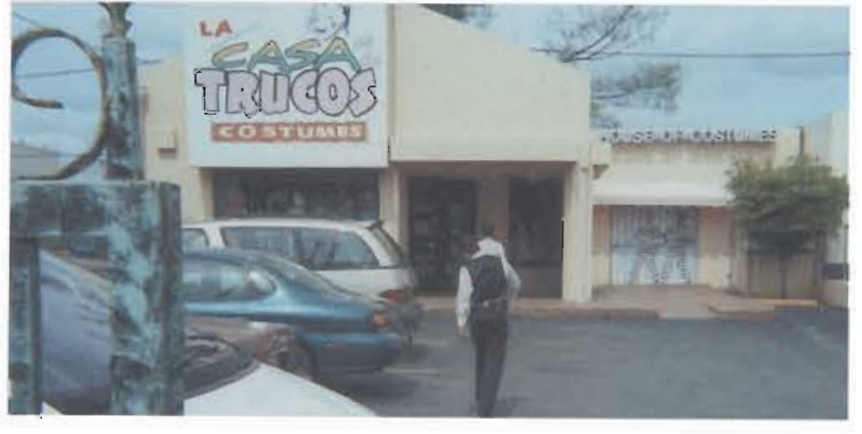

Figure t. 1343.
$1351,53,55$

BUILT: 1938

OWNER: Esteban Torres

1351

*1938 George Merrick Real Estate

1939 Owen Fuelow Real Estate

1940 George Rock Plumber

1957-60 Corbertt Real Estate

1960-69 vacant

1969-73 La Commercial Meat Market

1973 La Complaciente Meat

1974-76 Blanquita Record

1353

1941-47 Elmer Schwinger

1953 vacant

1960-62 Morris SchultImam

1963-67Alberto Fuentes

1969 Vacant

1970-73 Francisco Perez

1976 Municipio San Antonio de los Banos 
1963-69 Toyo Bakery

Note: Mr. Estevan Torres has been in this location for 28 years. Thirty-eight years ago, he escaped Cuba in a 14-foot boat. His business La Casa de Los Trucos, is the same as his family had in Cuba since 1934 located at Bernardo \#115 in El Vedado back in Cuba. 1351 was the location of George Merrick's Real Estate office in 1938 during the development of Coral Gables.

$1357,59,61$

BUILT: 1938

OWNER: American Oil Co.

TENANTS:

357

1938-39 Frank Raymond

1940 Orr MacNiven

1941 Kieth Crosby

1942 Vincent Nolan

1947-49 Charles Loss

1949 Alberta Folsom

1953-56 Emil Jum

1957 vacant

1959-60 Leonard Bendara

1960-62 Ethel Sullivan

1964 Eugenio Gonzalez

1966 John Okelley

1967 Juan Nunez

1969 Jose Portela

Listings end at this year

1942-47 Paterno Sylvan Upholstery

1953 Dade Federal Saving Association

Trail Recreational Pool Parlor

1957 vacant

1960 Pan Am Electronics
1962 vacant

1964-69 Harry Dry Goods

Listings end at this year

1361

1941 Jason McCaffrey

1942 vacant

Listings end at this year

1377

BUILT: $1927 / 1966$ addition

OWNER: F.G.Giel Truss

TENANTS:

1377

1927-29 Andrew Cowgill Filling Station

1930-41 Southwest Service Station

1942 Cowgill Service Station

1947 Culpepper Service Station

1949-57 Brooks Service Station

1959-62 Cimo American Service Station

1967-69 Quimo American Service Station

1970 vacant

1970 Perez American Service Station

1973 Piedra American Service Station

2000 Amoco

\section{$14^{\text {th }}$ AVENUE:}

1401

*BUILT: 1928

OWNER: Tamiami Methodist

TENANTS:

1928-00Tamiami Methodist Church

Note: Originally built in 1928 and has always been The Tamiami Methodist Church.

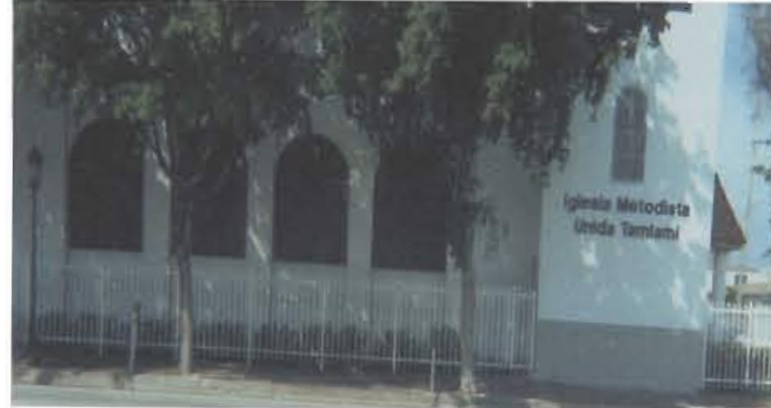

Figure u. 1401 
TENANTS:

1937-39 Thriftmart Grocery

1940-42 Shells Grocery

1949-67 Syvan Paterno

1969-76 Muiblicenter Furniture

1980 Almacenes Pepe \& Berta

$1421,23,25,27$

BUILT: 1968

OWNER: Murray Rozynes

TENANTS:

1421

1971-72 Rosan Shoe and Fashion

1973 General Finance Corporation

Scorpion \& Perez Insurance Agency
Carlin \& Torres Realty

$1423,25,27$

Artect Business College

2000 vacant lots

$1443,53,61,67,69$

BUILT: 1979

OWNER: City of Miami

TENANTS:

1443

1976 Musicland Musical Instruments

1453

1937-41 Mammoth Food Stores and Cushmam Bakery

1947-49 Margaret Ann Market

1953 Home Furniture

1956-60 Soul Music Jukebox Co.

1964-76 Occidental Electric

1467

1929 Peoples Poultry and Egg Farm

1469

1929 George F. Fruits
BUILT: VACANT LOT

OWNER: City of Miami

TENANTS:

1937-39 John Solomon Filing Station

1940 Sheldon's Filling Station

1941-42 Walters Service Station

1947-57 AP Shell

Souza Service Station

1970 vacant

1971-72 Cruz-Pino Motors

1976 El Progresso Mechanic and Tire

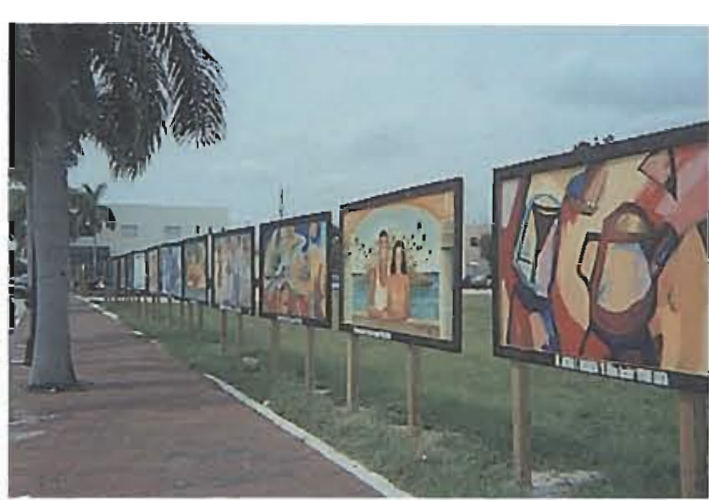

Figure v. 1475

\section{$15^{\mathrm{TH}}$ AVENUE:}

1501, 03. 05, 07, 13

BUILT: 1926

OWNER: Alexis Jepeway

TENANTS:

$1501,1502,1503$

1933 Edward Mason Milk

Distributor

1934-38 Puritan Dairy Store

1939-40 Al E. Restaurant

1949-56 Tower Restaurant

1957-59 Mozzee's Restaurant

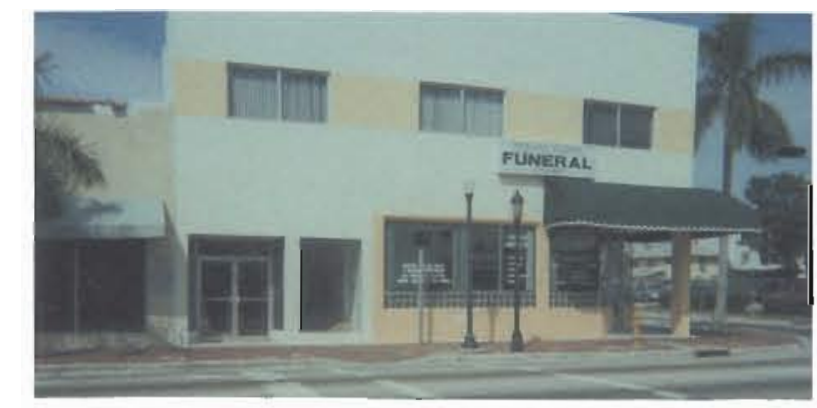

1960 vacant

1962-64 Givoria Catering

1966 vacant

1967-72 National Drugs

1976 Clinica La Fe 
1977-00 Futurama

1505

*2000 Little Havana Funeral Home.

1925 Shenandoah Service Ice Station

1941-47 Alfonso Burke Restaurant

1507

1977-00 Futurama

1938 Earl Coffin

1939-40 Farrell M. Tittsworth Real Estate

1941-42 White Radio Service

1947-56 Tower Radio Repair

1957-60 vacant

1962-69 Kitty's Apron Shop

1970-72 vacant

1513

1973 not listed

1935-41 Ball \& Chain Saloon

1960-66 Copa Lounge

1967-00 Futurama

Note: The seniors in Domino Park were very upset because the funeral home occupied the establishment across the street. They tried to stop it, but it was approved by the city.

1521, 25

BUILT: 1938

OWNER: JDC Corp. $/ 1990$

TENANTS:

1521

1927 Morris Zohn

1937 Mrs. Rose Baker Knit Goods

1938-42 Ber-Mel Knit Shop

1947-49 Blumenbach Sales Electronics

1953-59 Kesslers Radio and Television

1960 Tower Furniture

1962 Lamps by the Thousands

1964 Fast Appliance Service

1969 Tommy's Fashion

1971-76 Latin American Collection

1966-00 Dukanee Beauty Supply
1937 Tower China Shop

1938 Pangle Kodak

1939-40 Lamac Shoe Repair

1941-42 La-Mac Shoe Rebuilders

1949 Ernie's Expert Shoe Repairing

1953-56 Mac's Paint

1957-62 Puritan Ice Cream

1964-1976 El Pescador Fish Market

2000 vacant

1525

1937 Trapnell Drug

1940 vacant

1941-42 Farris Ice Cream

1947-56 Jaffee Ice Cream

1957-62 Mac Paint \& Hardware

1964-66 El Canado Hardware

1967 Special Hardware

1969-76 Dukanee Beauty / Barber Shop

1529, 35

BUILT: 1946

OWNER: W.J. James Truss

TENANTS:

1529

1953 Nelson's Laundry

1956-67 Thorton's Laundry

1969-76 Joyeria Milies

1976 El Pescador Restaurant

2000 Pizza Hut

1527

1949 Factory Outlet Floor Covering Corp.

1966-76 Ernie's Shoe Repair

2000 Pizza Hut 
1543, 45

BUILT: 1956

OWNER: Roberto Daniel/1981

TENANTS:

1543

1957-62 International Sales Corp.

1545 1964-72 Findlay Clinic Lav.

1957-62 Sandborn Co. Medical Supply

1970 vacant

2000 El Pescador Seafood

$1551,53,55,57,59,63,65$

BUILT: 1925

OWNER: JDC Corp. $/ 1990$

TENANTS:

1551

1931 Hyman Mechlowitz

1933-38 Everglades Grocery

1939 Hardy Dunn Grocer

1941 John Skelton Bakers

1942 Walter Stoffer Baker

1947 Kappy's Fine Foods

1953-57 Murry's Delicatessen

1959 Malboro Restaurant

1960-62 Wolf's Industrial Catering

1966-60 Tropical Grocery

1970-76 Las Brisas Super Market

1976 Orialda Frenandez

1553

1938 Makar Olsey Tailor

1939 vacant

1940 Frank Athansaw Billiards

1947-5019 United Kosher Meats

1555

1928 New Washington Market

1929 vacant

1947 Electronic \& Sound Services

1949-57 Ryan Radio
1959 Bargains in Books

1960 vacant

1962-64 Tropical Grocery

1966-76 Hurricane Printing 
$1565,67,69,75$

BUILT: 1984

OWNER: Toddrick Inc.

\section{TENANTS:}

Seventh Dunkin Donuts Realty Inc.

1565

\section{Parking Lot}

1933-38 Mortimore J. Shaw Gas Station 1938 Charles Caruso Iron Works

1939 vacant

1940-42 Wendel Filling Station

1947 George Nemetz Filling Station

1949-53 Shenendoah Service Station

1956-64 Blue Bar Service Station

1966-76 Star Service

1993- Dunken Donuts

2000 vacant

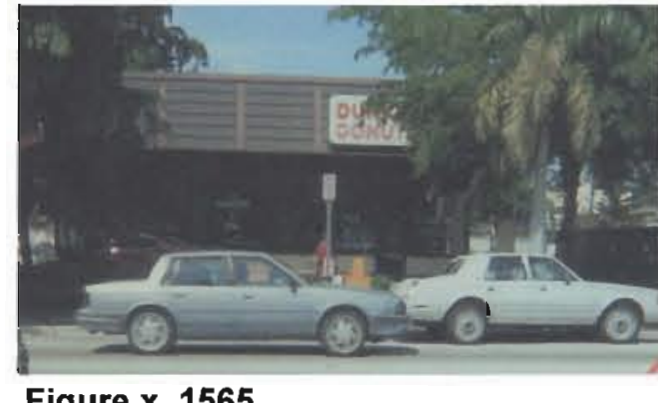

Figure x. 1565.

\section{$16^{\text {TH }}$ AVENUE:}

$1601,03,05,07,09,11$

BUILT: 1938

OWNER: H,A. Berk

TENANTS:

1601

1933-35 New Washington Market

1937 National Package Stores Liquors

1940-62 Knights Package

1966-69 Shell City Liquors

1603

-76 Rey Joyeria

1937 Joseph Kadar Shoe Repair

1938 George Sprinkle Shoe Repair

1939 vacant

1940-41 John Sacker Exterminator

1942 vacant

1947 Gordon Carlile Real Estate

1953 Air Way

1956 Fordyce Electronics

1957 Gamble Enterprises (1603-07)

1960 vacant

1962 International Electric

1966-70 Lopez Optica

1972-73 Manuel Duval Phy.

1605

1957-60 European Photo

1962-73 Orlando Fine Furn.

1607

1956-60 Not listed

$1960-70$ vacant

1972-74 Optica Cubana

1609

1957-73 Welch Apts.

161

1957 vacant

1960 Hurd /Thelma Manuf.

1962-66 vacant 
$1613,15,35,37,39$

BUILT: 1978

OWNER: Jose Guevara

TENANTS:

1613

Vacant lot

1615

1953 Air Way

1956-64 Rahal Sons, Inc

1966-70 Arabic Grocery

1970-76 Vel-Mart Equipment Figure y. 1613-39.

1637

2000 Espana Importers

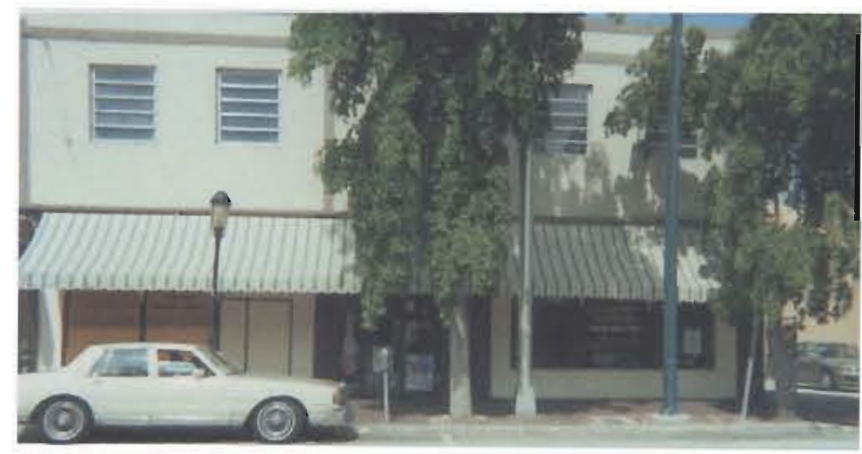

1957-62 Western Auto

1966-73 Chrome \& Iron Works

1639

1937-41 Brownie Keep-Fit Bowling Alley

1942 vacant

1957-37 not listed

\section{1}

BUILT: 1958

OWNER: Sher Enterprizes/1976

TENANTS:

1641

\section{AAA Manufacturers}

Used Cars

1953 vacant

1957 not listed

1960 Moser \& Son

1962 Security Real Estate

1964-72 Barkins Construction

1973-76 Security Real Estate

1993 Beepers

2000 Tabaqueria Popular

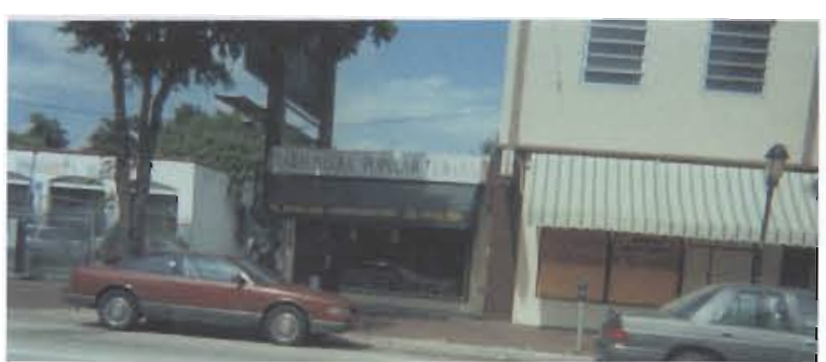

Figure z. 1641
BUILT: 1930

OWNER: D. Higginbotham

TENANTS:

1643

1957-73 National Brand Tires

1651

U. S. Jewelry

1695, 99

BUILT: 1988

OWNER: Floval Oil Com.

TENANTS:

1699

1957 Joe \& Irv Serv. Station

1960-62 Joe Pure Oil Serv. Station

1966-67 Trail Pure Station

1969 A A A Auto

1970-72 Pedro Pure Oil Station

1973 Pedro Union Station 


\section{CHAPTER 7:}

\section{CALLE OCHO REVIVED:}

\section{Proposed Artist Studios designed using Cuban Ethnic Elements produced during 1960-1973.}

Urban streets are in a constant dynamic change in a cycle of life and death. This constant cycle is typical of American urban streets particularly in immigrant cities. After a long cycle of decline there seems to be a glimmer of hope for Eighth Street in the form of Artists who are migrating into this area.

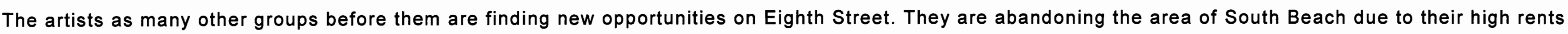
caused by the area's up-swing cycle. Artists find Eighth Street attractive because of its economic rents, small-scale urban life and its ethnic flavor

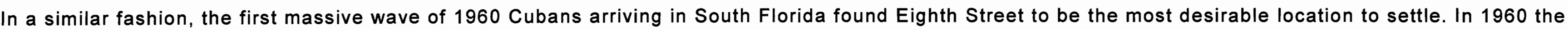

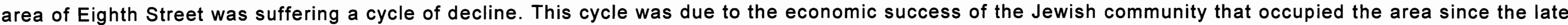

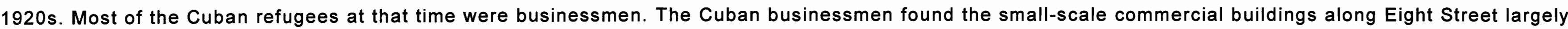
constructed by the previous Jewish businessmen, ideal for their new start. The Cubans created a cycle of life for Eighth Street and introduced ethnic urban elements, which are still present in this area and in South Florida. 


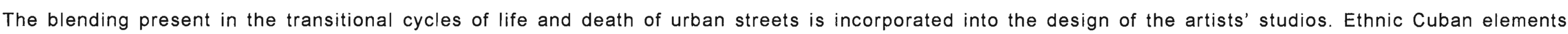

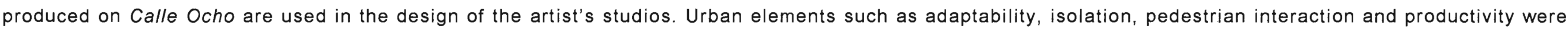
incorporated into the designs of the artist's studios.

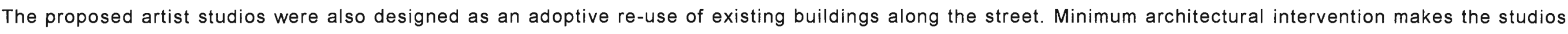

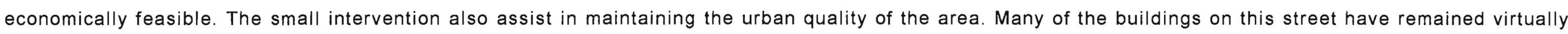
intact except for the functional adaptations by their tenants in order to attain a viable economic situation.

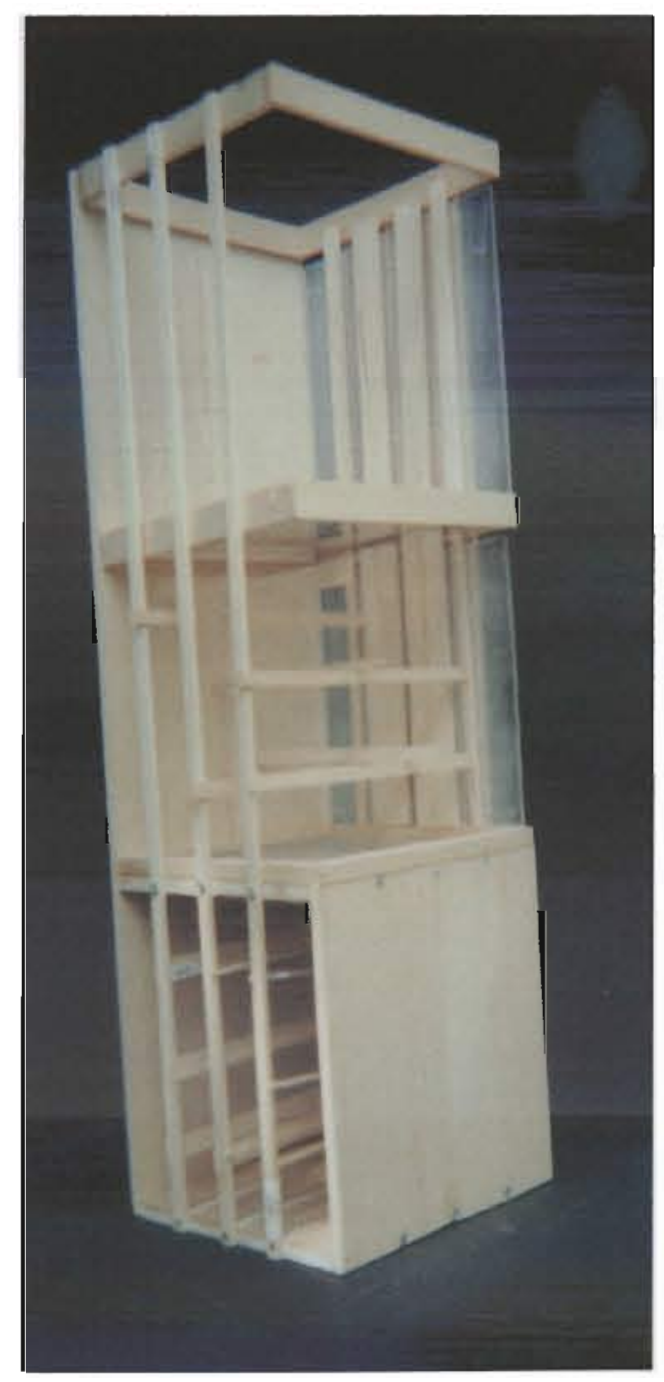

\section{Figure 57.}

The sculpture shown on the left represents the life cycles of Eighth Street. Three 8" cubes represent the stages of growth on Eighth Street. The lower cube represents the pioneer stage that eventually sealed the fate of this area. The pioneers sold their large plots of land and the land was re-plotted into smallscale lots making the area economical. The middle cube represents the cycle of the Jewish community. The top cube represents the Cuban settlement in the area. Transparent plexi-glass planes divide the stages to communicate the blending of the slow transitions between the urban cycles. 


\section{SITE ANALYSIS}

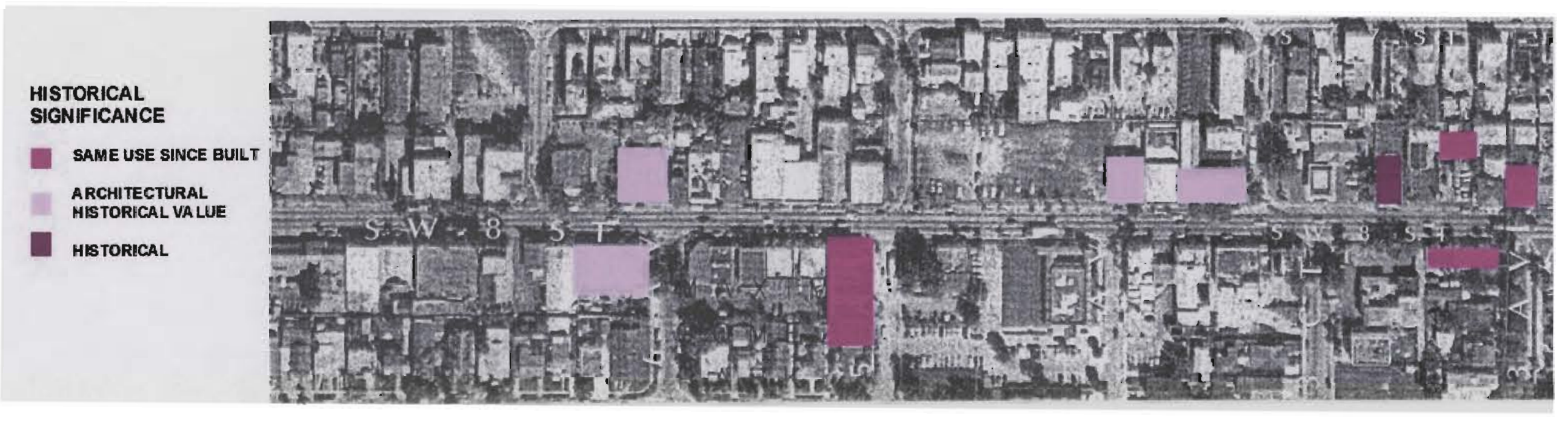

Figure 58.

Most buildings along Eighth Street have little Architectural historical significance with the exception of the Tower Theater. Some structures have minor architectural motives typical of the mid$1920 \mathrm{~s}$. It is interesting to note that some buildings have served the same function since the day they were first occupied.

\section{ETHNIC JEWISH BUSINESSES \\ 1920-1930 \\ 1931-1940 \\ 1941-1950 \\ 1951-1960}

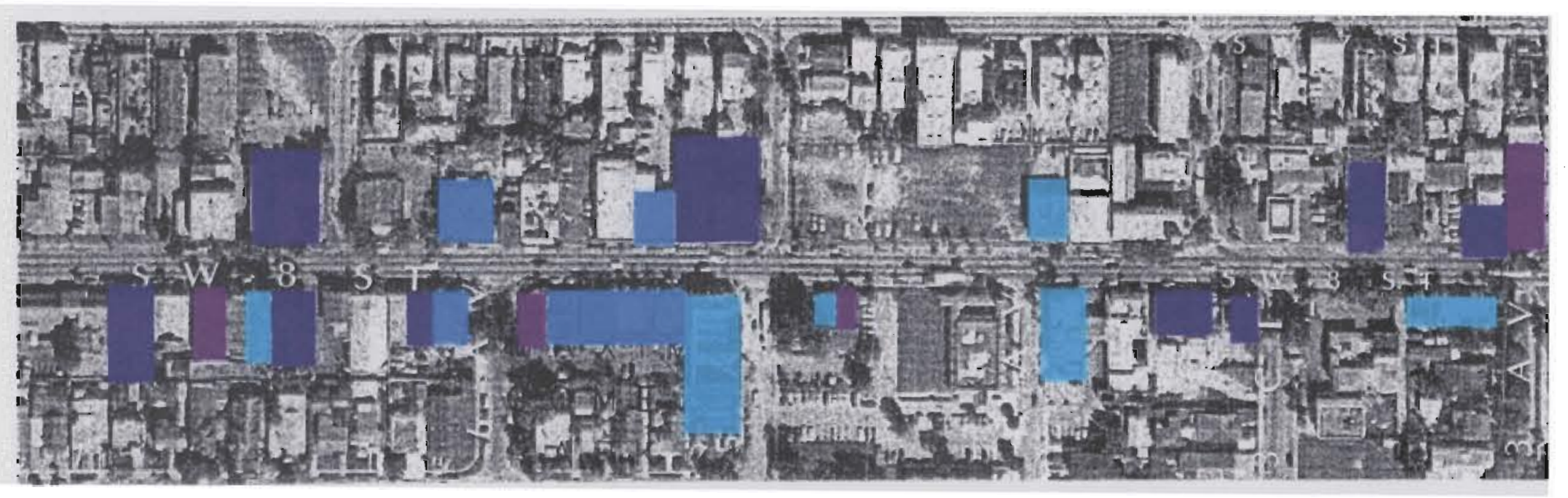
the 1930s. Numerous buildings were constructed at this time, creating a small-scale commercial artery. These buildings were then occupied by the 1960 Cuban migration. 


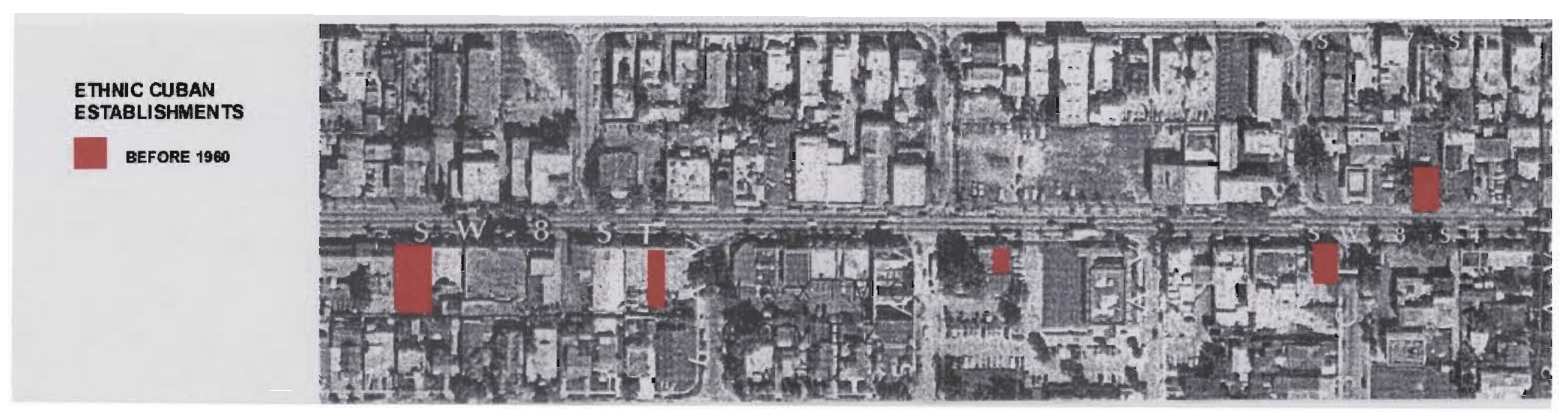

Figure 60.

Approximately 10,000 Cubans were already established in the area of Eighth Street by late 1959. The analysis indicates the Cuban businesses on this street before the massive immigration starting in 1960

\section{ETHNIC CUBAN ESTABLISHMENTS
1960 - 1973 \\ (11) CAFE WINDOWS \\ - tobacco \\ OTHER}

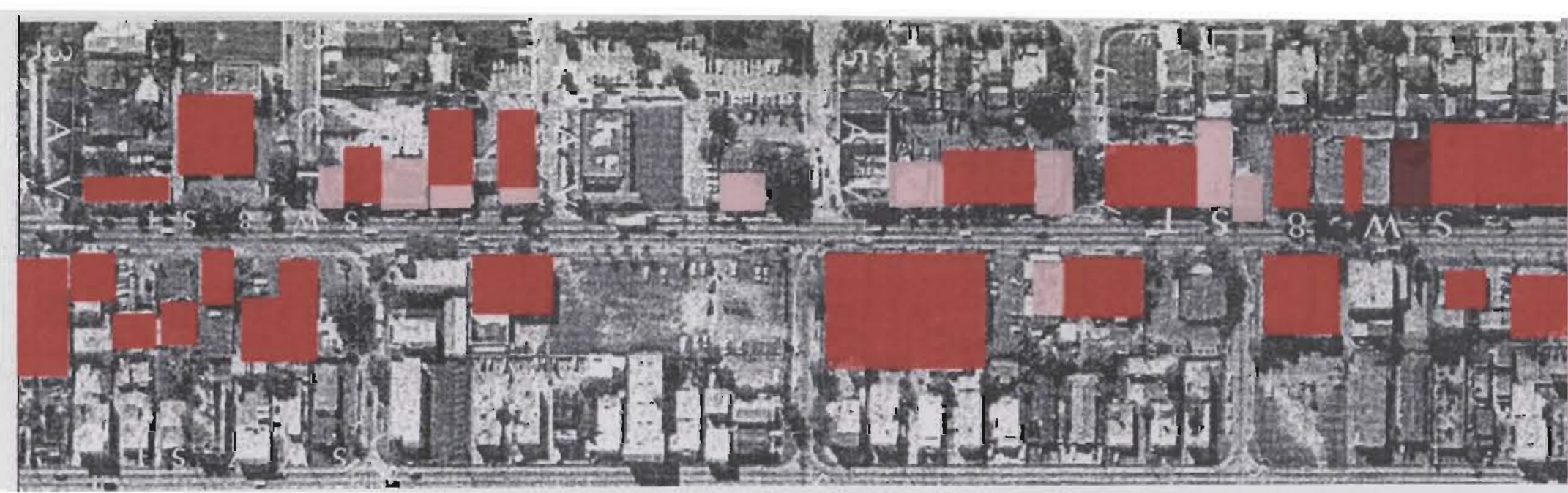

Figure 61.

Most Cubans entering South Florida in 1960 settled in the area of Eighth Street. In less than a generation many Cuban refugees had achieved economic success. The numerous ethnic shops catered to the 300,000 Cuban exiles that lived in the adjacent area. 


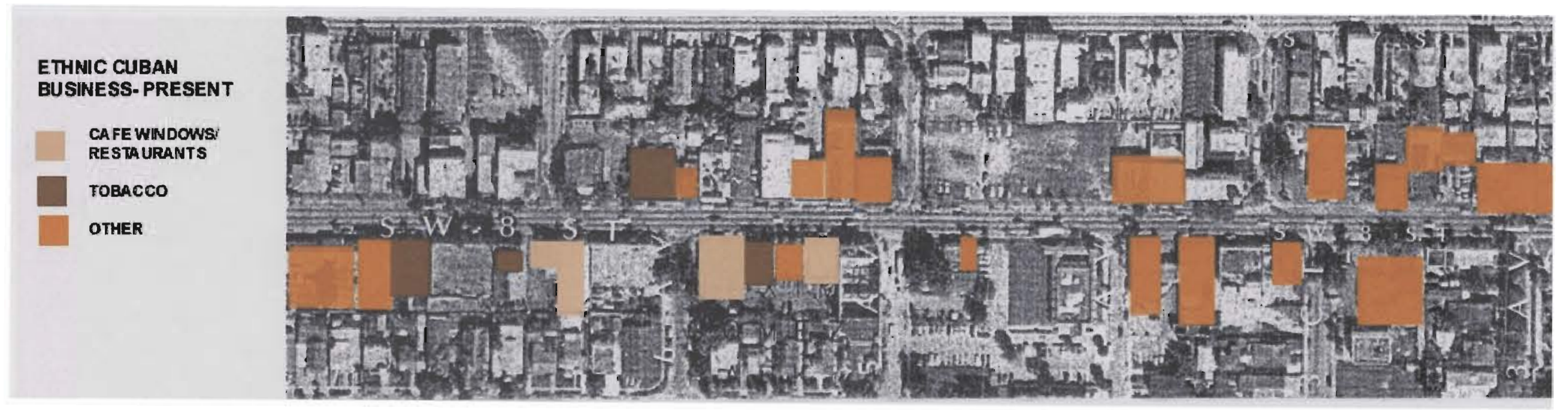

Figure 62.

Still today many business along Eighth Street remain Cuban owned. The numerous influxes of Cubans in the 1960 s and 1970 s left a strong ethnic hold on this area. The Latin influence attracted many Central Americans to this area

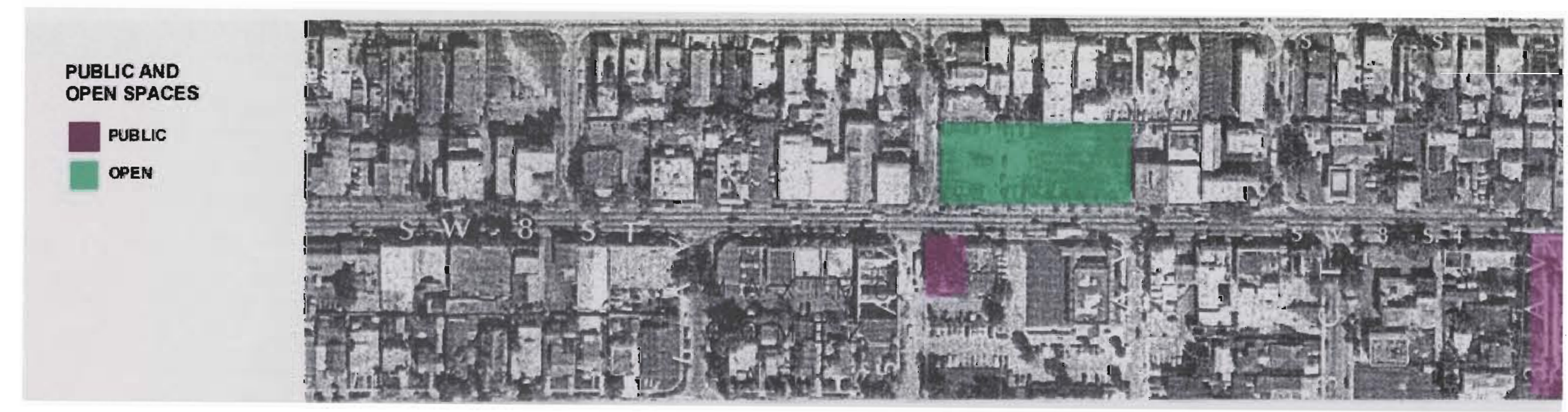

\section{Figure 63.}

Cubans created monuments along $13^{\text {th }}$ Avenue also known as The Cuban Memorial Boulevard. Monuments are still being planned along this shaded boulevard. Maximo Gomez Park on $15^{\text {th }}$ Avenue and Calle Ocho offer a safe place for senior citizens 


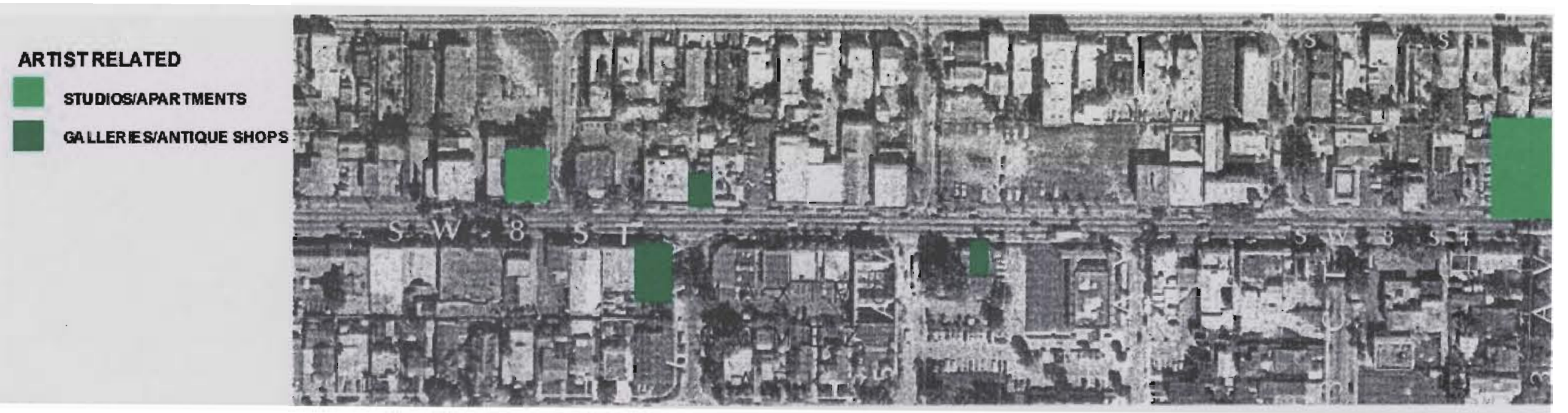

Figure 64.

Artists are currently occupying several areas along Eighth Street. They have also brought with them antique shops and galleries. The proposed artist studios sites were selected based on the proximity of existing artist studios and galleries along Eighth Street

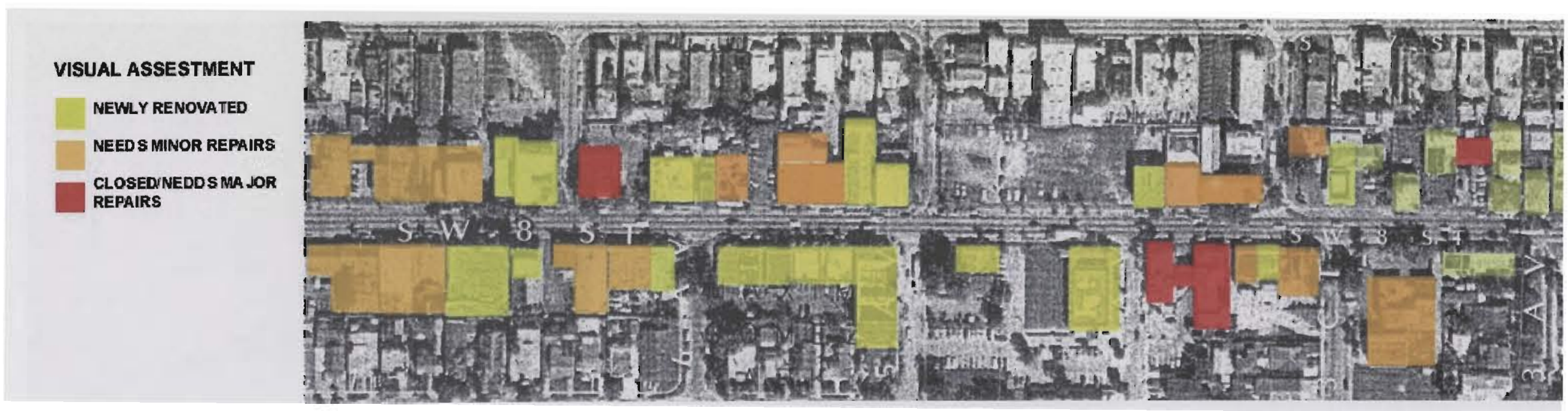

Figure 65.

The sites for the proposed artist studios were also selected based on the visual assessment of the street. In an effort to renovate the street sites were selected based on the areas that needed the most repairs. 


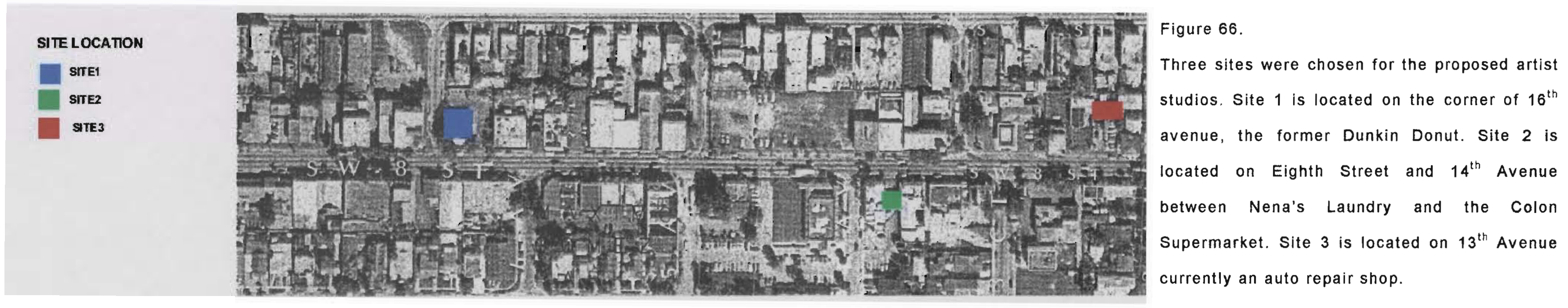




\section{SITE 1: $1565,67,69,75$ S.W. $8^{\text {TH }}$ STREET}
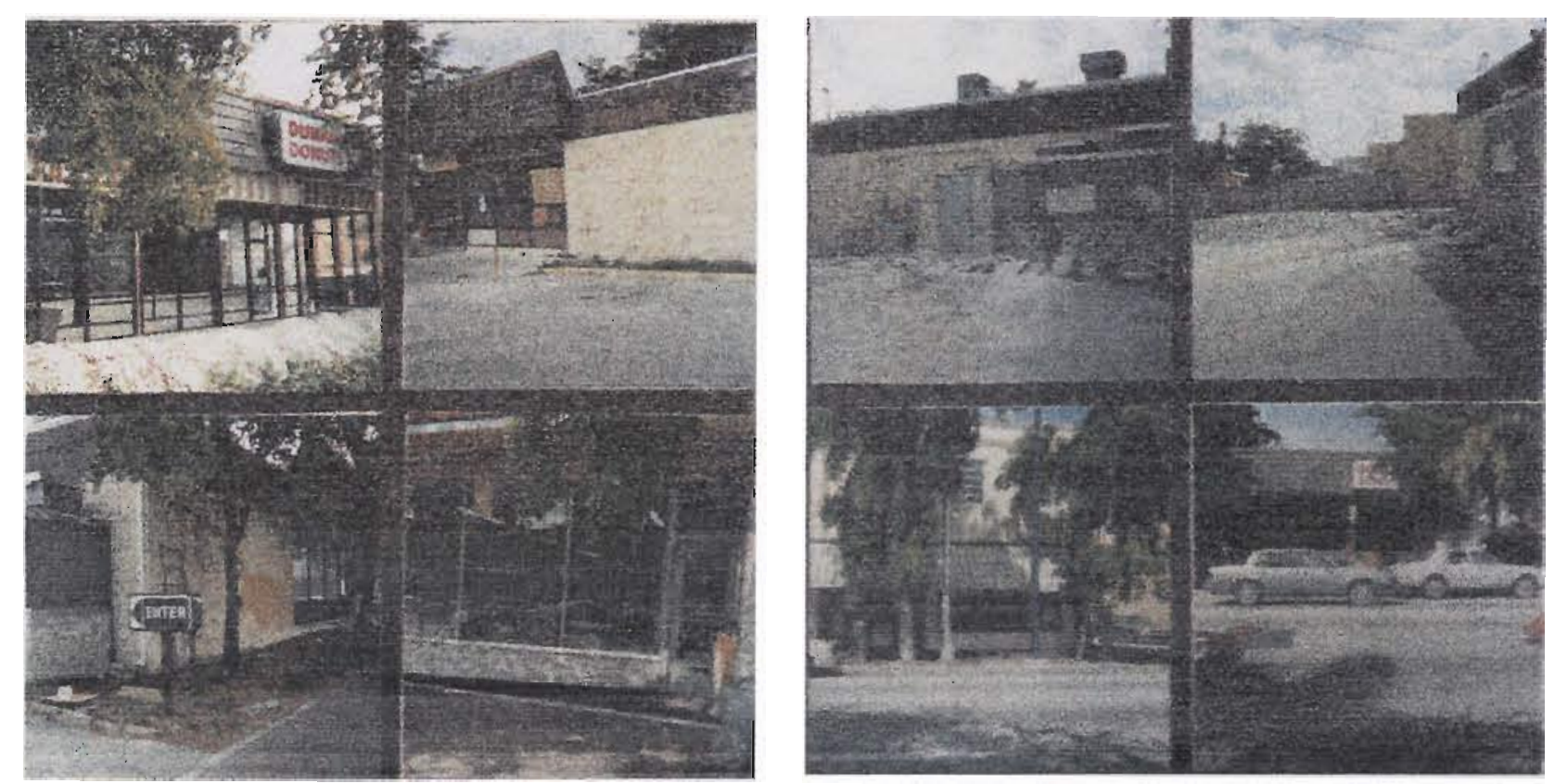

Figure 67. Site Fotographs.

The site is located on the North edge of Eighth Street on the corner of $16^{\text {th }}$ Avenue. Built in 1984, the former Dunkin Donut shop has been vacant from 1999 to 2001. From 1940 to 1984 the site contained a gas station.

The present structure is a typical Dunkin Donut franchise structure. The building is $40^{\prime}$ wide along Eighth Street by $x 42^{\prime}$ deep into the lot. It sits on the southwest section of the lot. The lot is $120^{\prime}$ along Eigtht Street by 150' deep. The building is $15^{\prime}$ ' high.

Several factors made this site ideal for the proposed artist's studios. The building was abandoned and an eyesore. It was also adjacent to artist's activities on its west. The proximity of the existing building to the sidewalks was a favorable factor. Another advantage is the ample lot, this enabled outside work areas and parking. The building's hight of 15 ' provided the volume desired in the artist's studios. 


\section{SITE1: PROCESS}
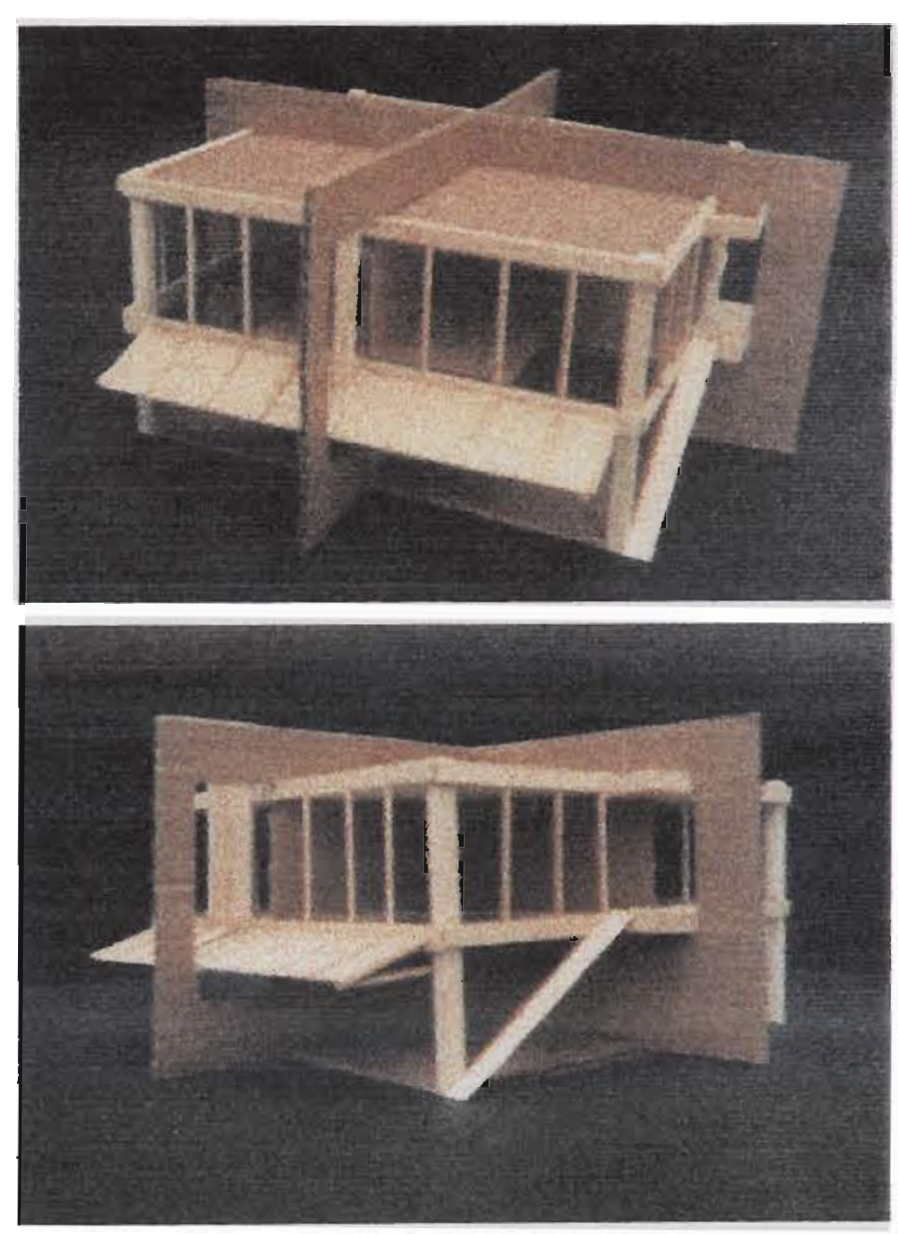

Figure 70. Preliminary Plan.

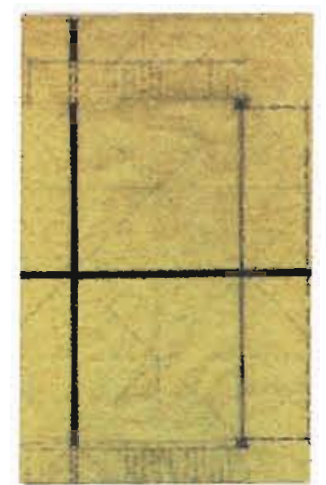

Cuban Ethnic elements of flexibility, pedestrian interaction and production were incorporated into the design of the artist's studios on this site. The organizational element of the grid was also incorporated as a gesture that recalls the structure of the plotted lots along Eighth Street.

Originally the proposal was to demolish the existing structure. The proposed building was to be erected in the same location and maintain the dimension of the former Dunkin Donut building. The two large planar grids served as structure and organized the interior space into four studio apartments. Each studio/apartment was composed of a 2-story unit. The top of the L-shaped floor was a small studio apartment. The bottom was a two-story artist's workspace and a gallery. Pedestrian interaction was encouraged by the exhibit area provided in the south and north side of the structure and the openness of the studios to the sidewalk. This solution was abandoned because it was more economical to maintain the original structure

Figure 68 \& 69. Preliminary Model.

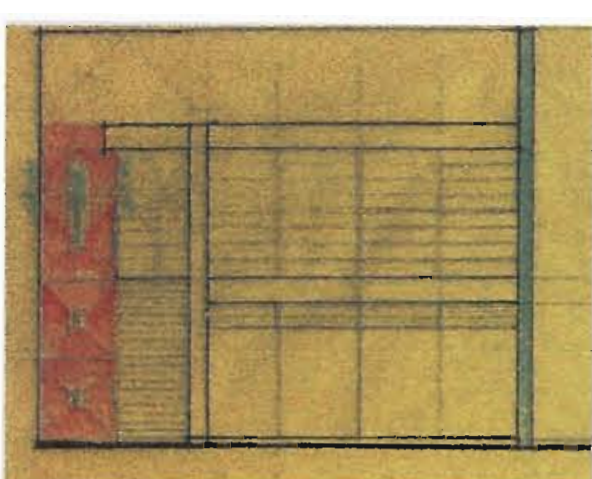

Figure 71. South Elevation.

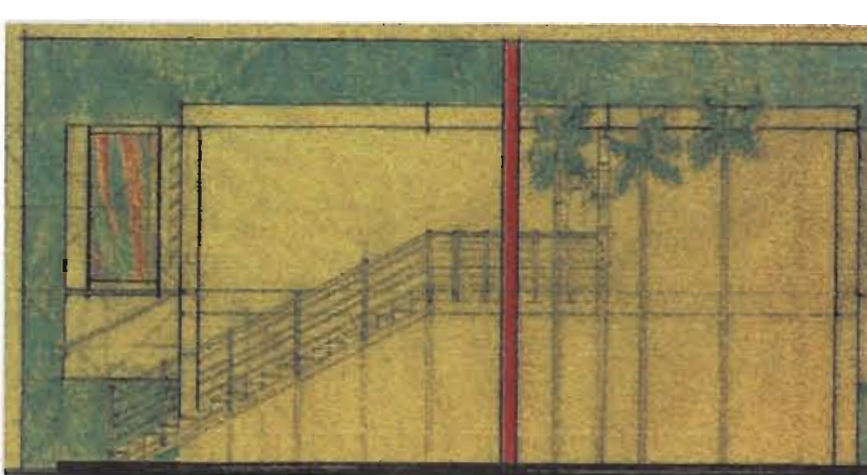

Figure 72. West Elevation. 


\section{SITE1: PROPOSED DESIGN SOLUTION}

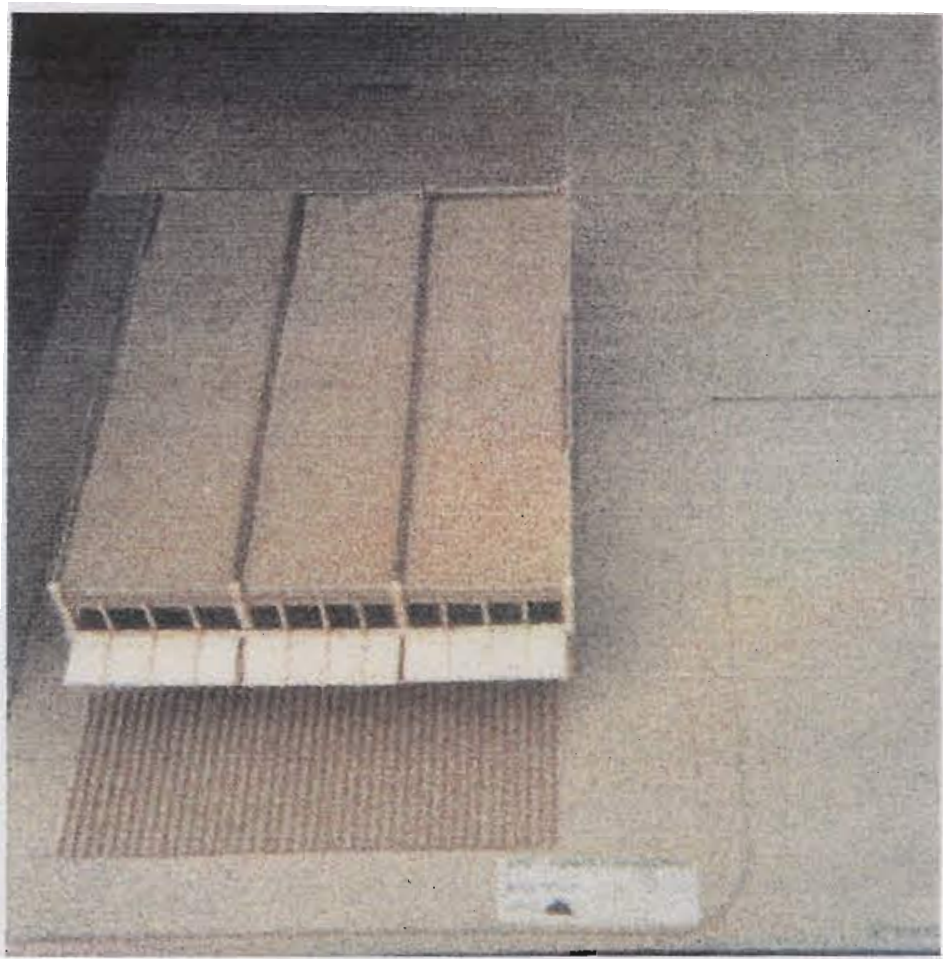

Site1 final solution incorporated the following Cuban elements:

*Strong relationship to the street

*Production

*Isolation

*Flexibility

Figure 74. Model of Proposed solution.

Strong relationship to the Street:

The building's location on the site fosters a strong relationship to the street as can be seen in the site plan. This relationship is emphasized by the $6^{\prime}$ overhang that protects the pedestrians. Also the exterior gallery area located next to the sidewalk along Eighth Street encourages pedestrian participation.

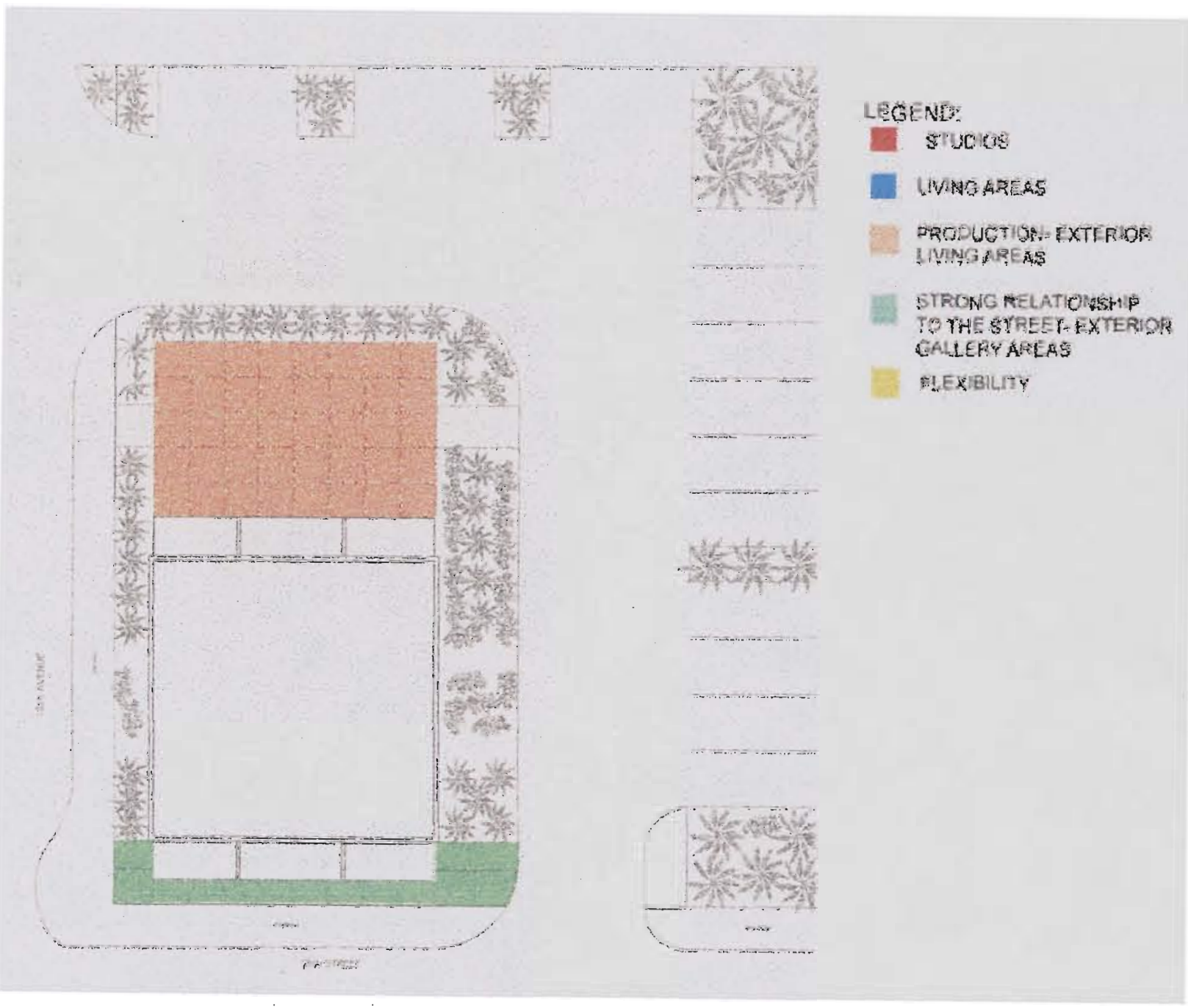

Figure 75. Site Plan 


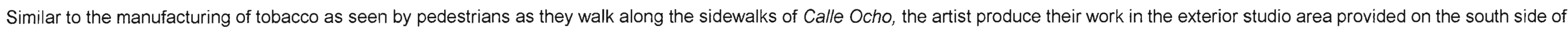
the site. The exterior studio is partially screened and shaded by heavy landscaping. Pedestrians can see glimpses of the artist at work.

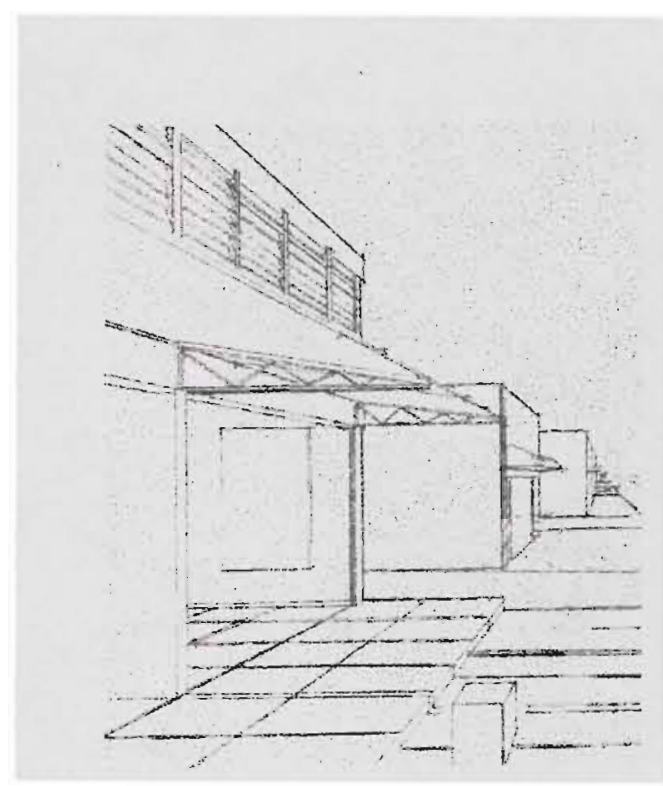

Figure 76. South Facade.

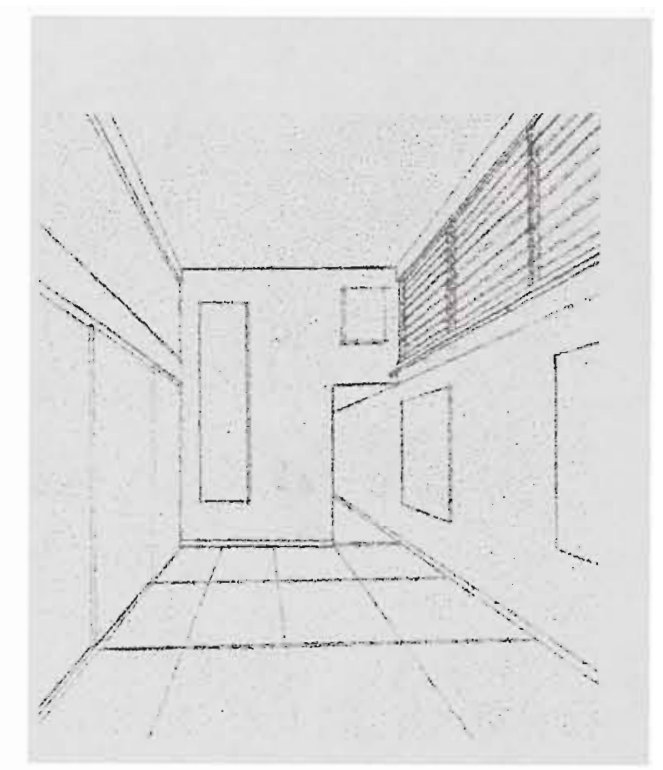

Figure 77. Interior Gallery,

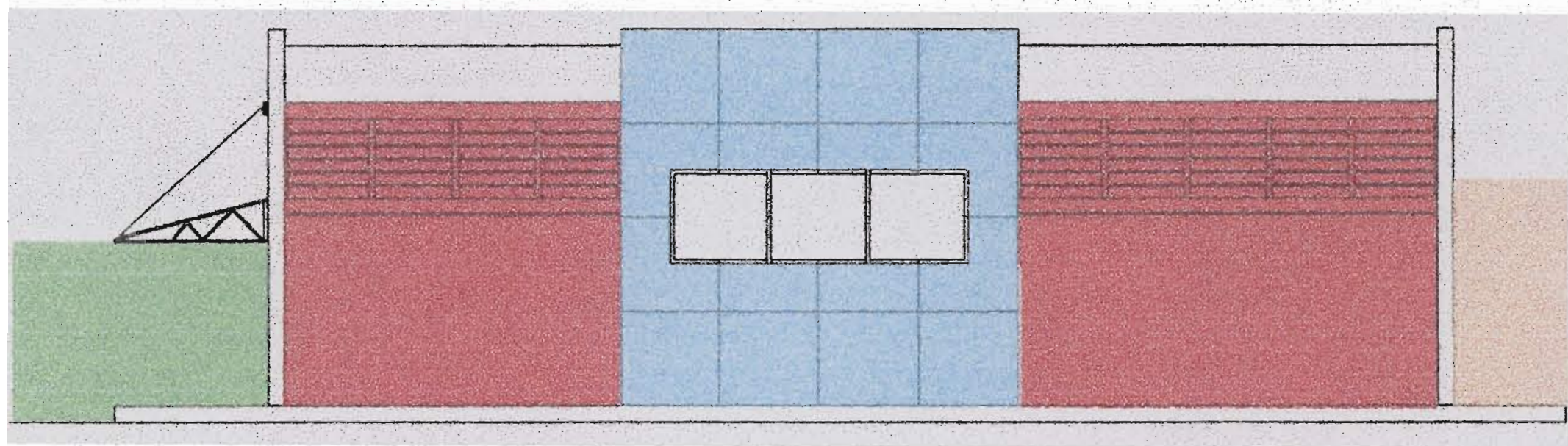

Figure 78. East Elevation. 
Flexibility:

Artists are offered the flexibility of renting individual units or the total building. The studios may be completely opened to be used as a large working area/gallery. Operable sliding panels between the units facilitate this adaptability

\section{Isolation:}

As sense of isolation is provided by elevating the living area as seen in the second floor plan and section located on the far right.

This change in elevation provides the opportunity

for ample storage. Privacy for the living area is achieved by entering from the north side opposite the Eighth Street facade.
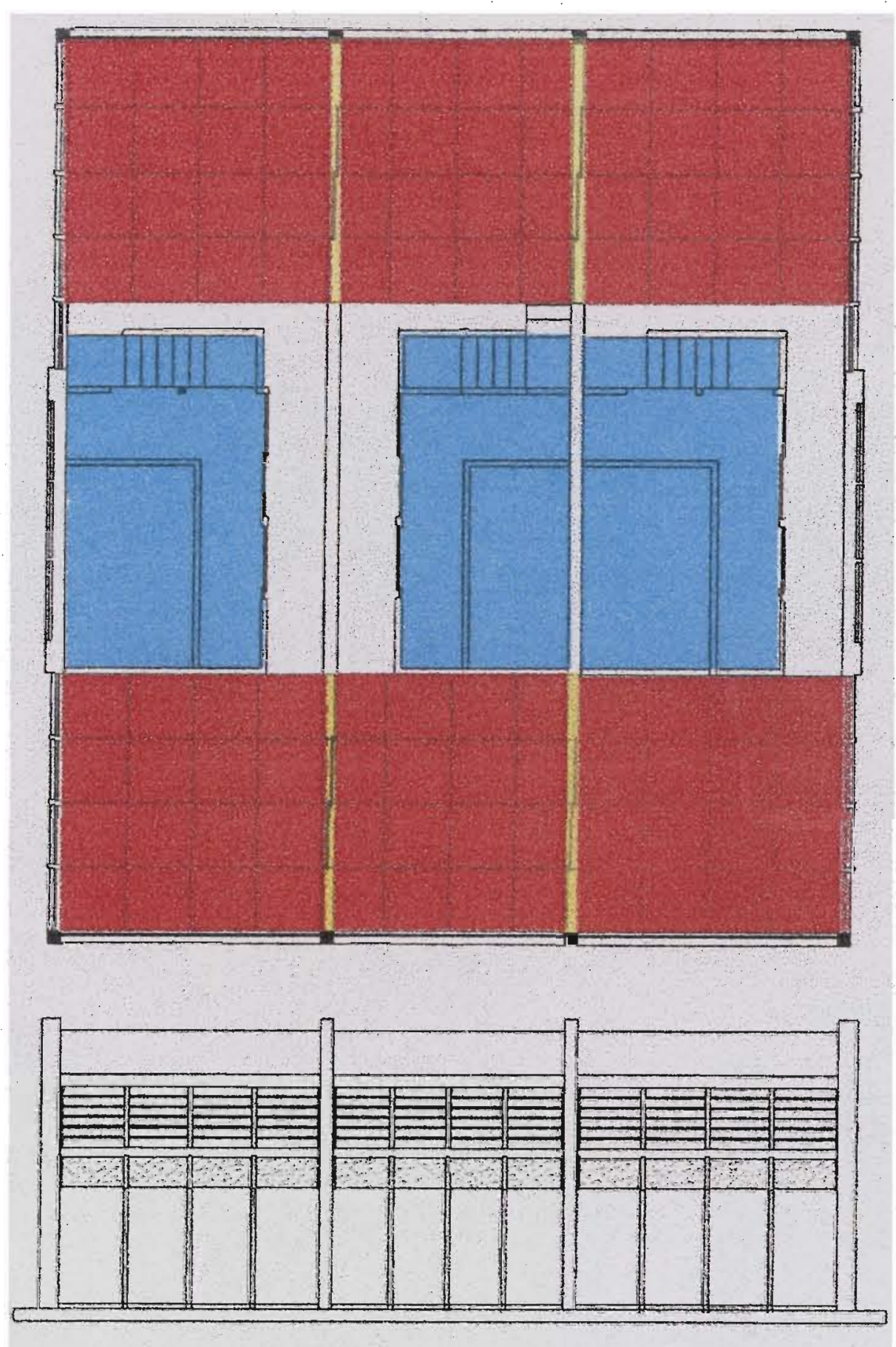

Figure $79 \& 80$. First Floor Plan above, South Elevation below.
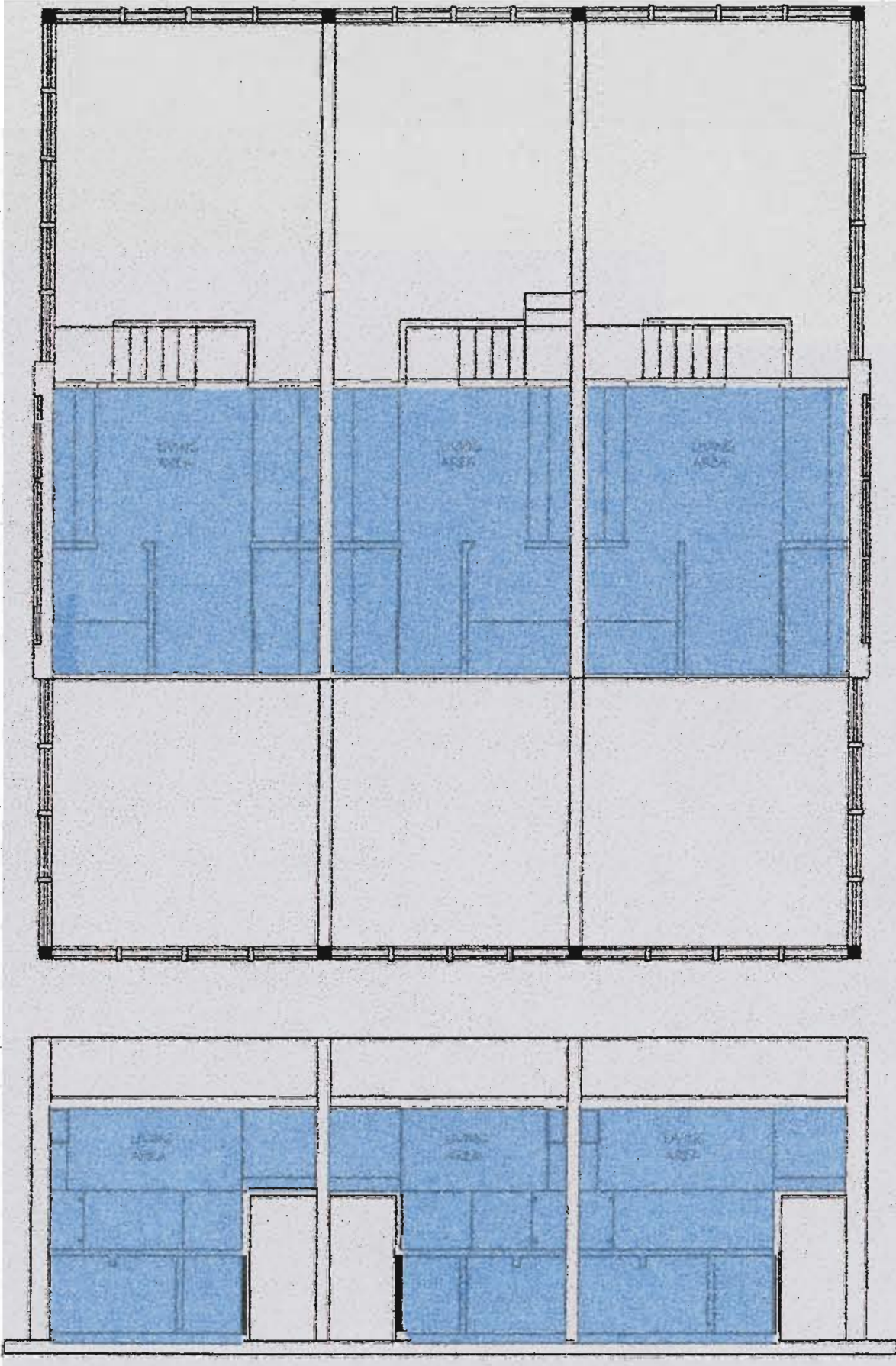

Figure 81 \& 82. Second Floor Plan above, Section below. 


\section{SITE 2: $1380,1388 \& 90$ S.W. $8^{\text {TH }}$ STREET}
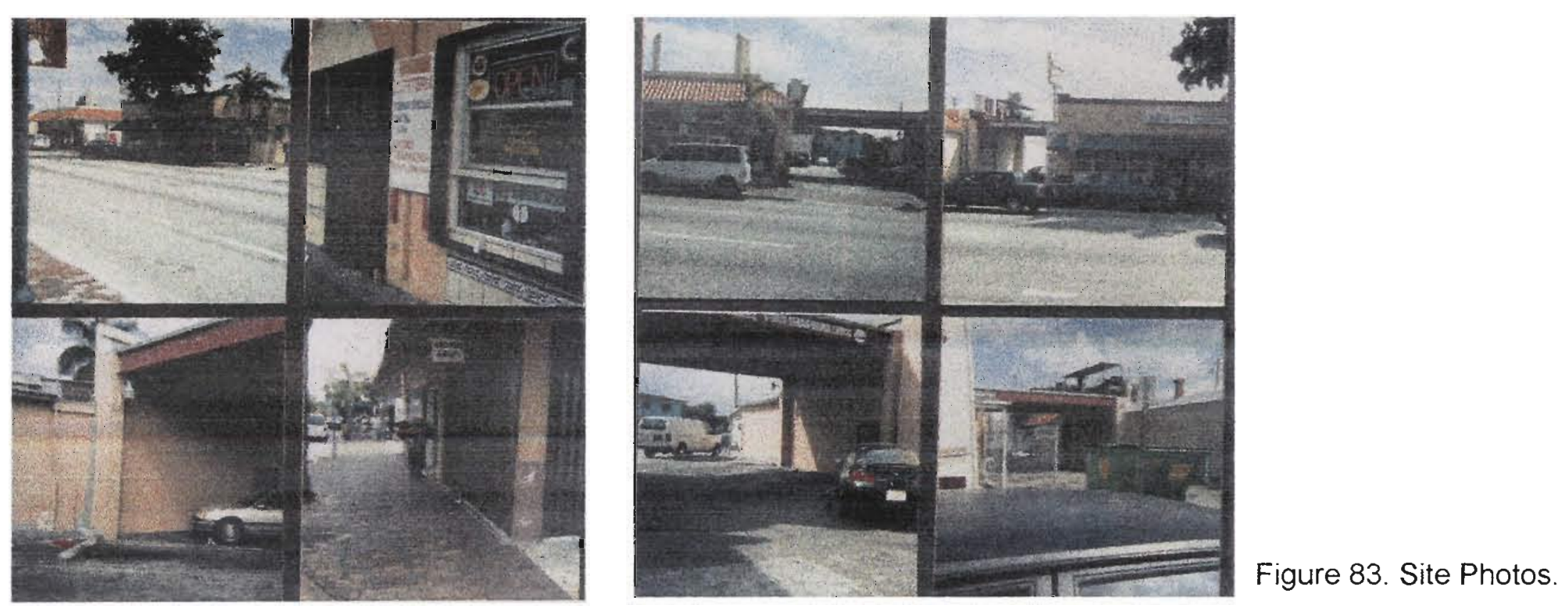

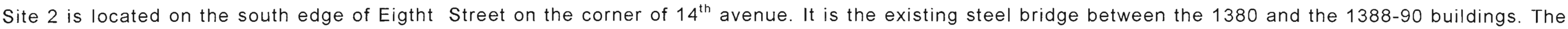

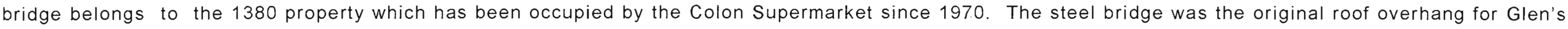

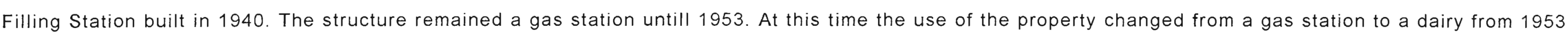

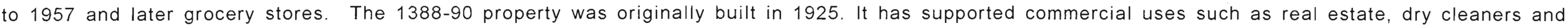
groceries

The dimensions of the existing structure are 31' wide on its east-west direction and 27 ' in its north-south direction.

This site was selected because the 1380 and $1388-90$ properties needed major repairs. It also offers an opportunity to create an isolated structure without disturbing the adjacent buildings 


\section{SITE 2: PROCESS}

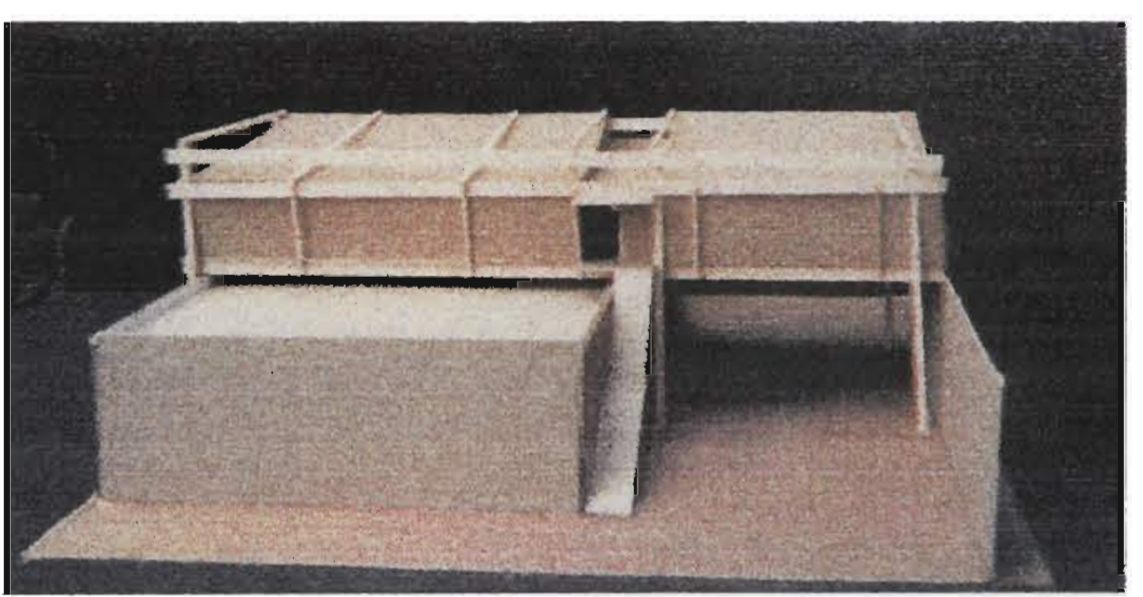

The Cuban ethnic elements incorporated into the solution of site 2 were flexibility and isolation

Two artist's studios and apartments were designed on this site. One unit was to be located directly on the existing steel bridge and the other unit was to span across the $1388-90$ building. The structure was designed to of very light materials such as steel and glass. This was to serve as a contrast to the existing buildings.
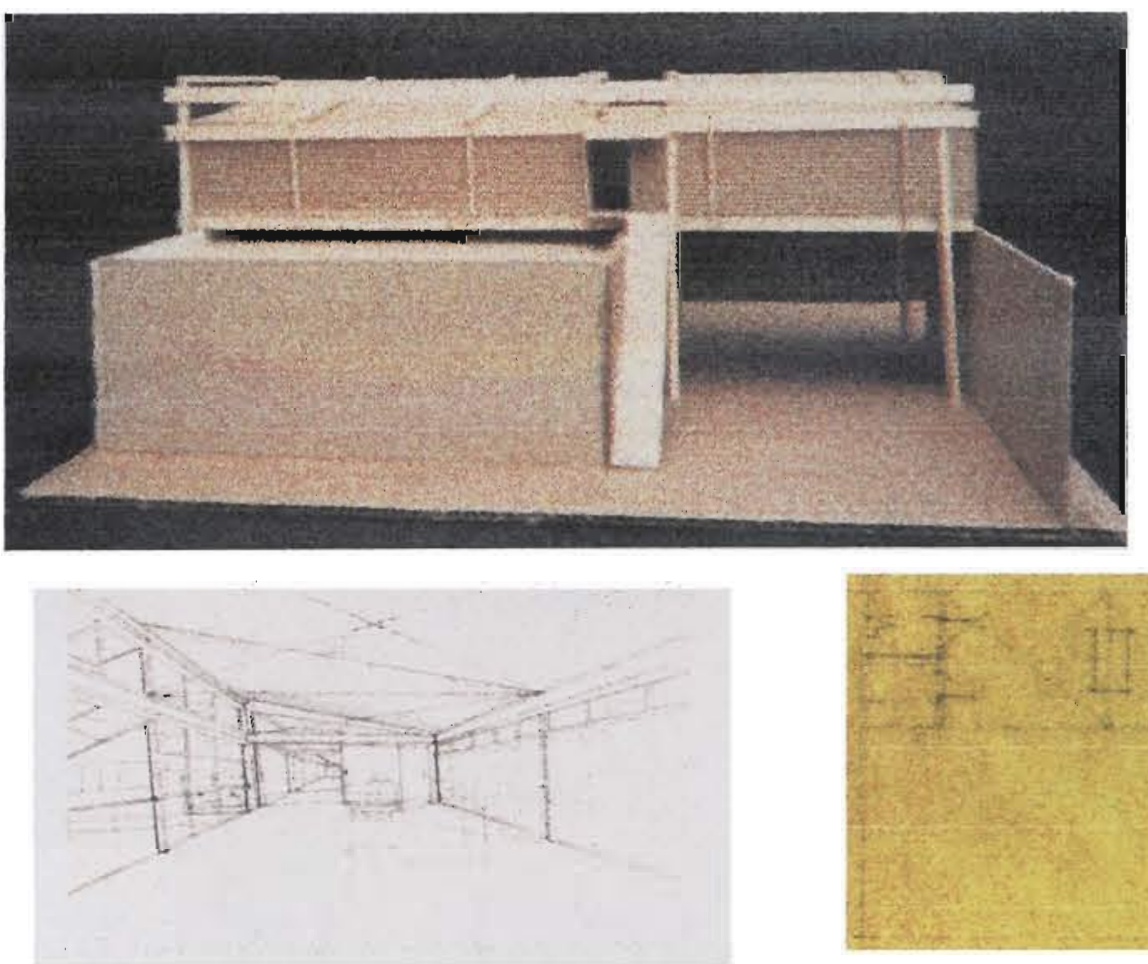

Figure 86. Interior Perspective.

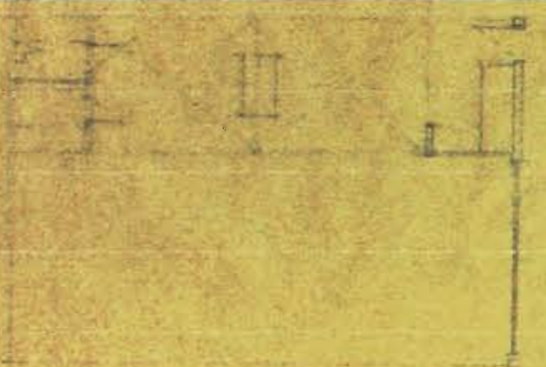

Figure 87. Preliminary Plan.

The design solution was abandoned because it was a very large intervention into the urban environment. The design solution was also not feasible due the fact that the proposed structure crossed over the property lines.

Figure $84 \& 85$. Preliminary Models.

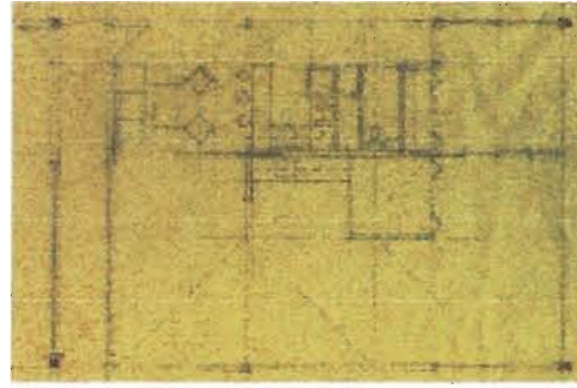

Figure. 88. Preliminary Plan.

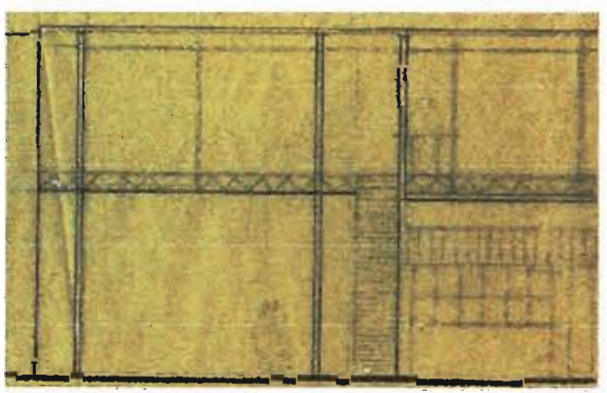

Figure $89 \& 90$. Preliminary Elevations

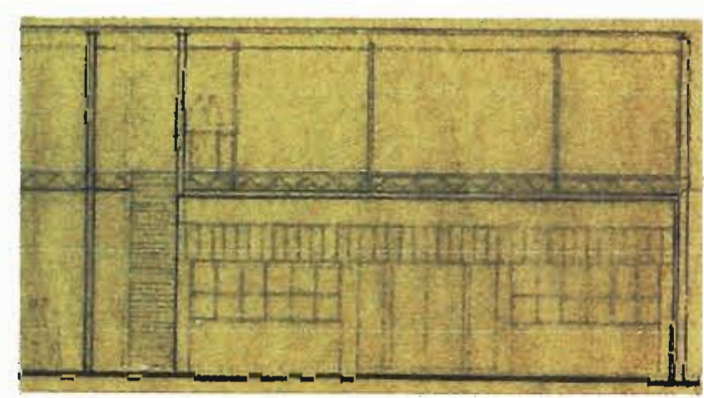


SITE 2: PROPOSED DESIGN SOLUTION

Site 2 incorporated the following Cuban ethnic elements into the design concept:

* Isolation

* Flexibility

\section{Isolation:}

The design concept for this site incorporates the importance of isolation as a major factor contributing to the Cuban economic success. Two artists studios are located on the overhead bridge between the existing buildings. The new structure imposes minimum interference to the overall urban environment

Figure 93. Site Plan
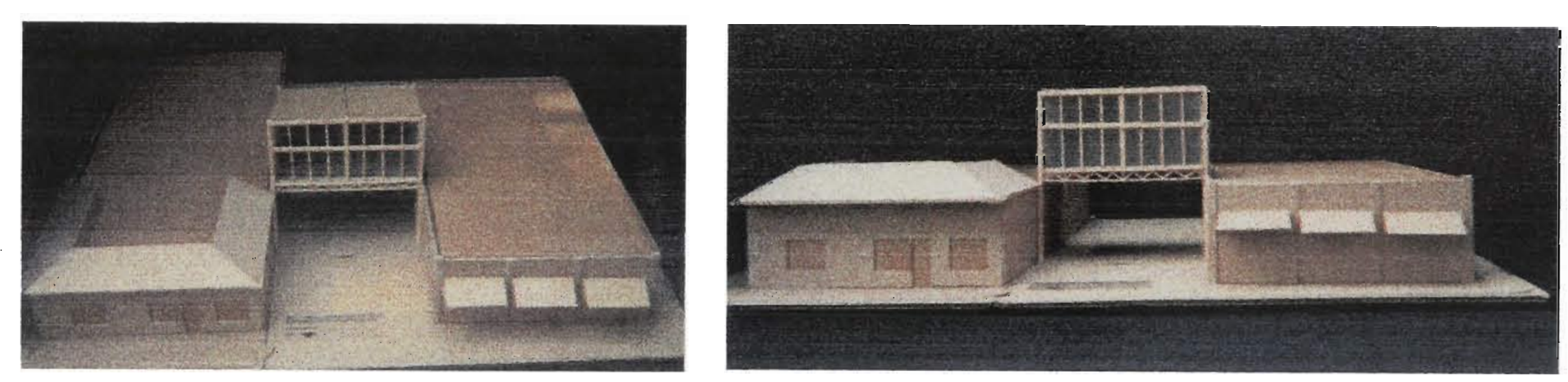

Figure $91 \& 92$. Models

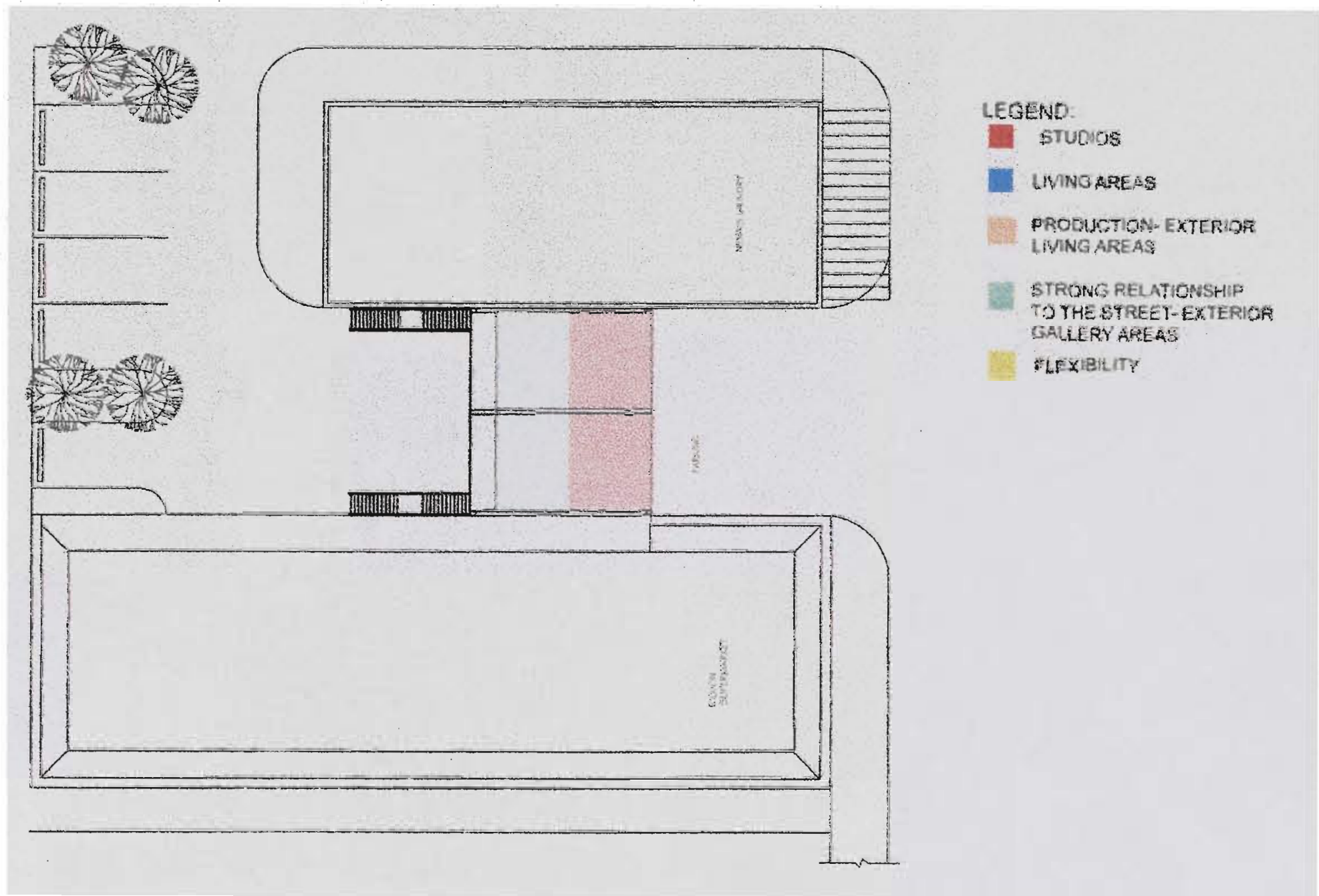


The adaptability and flexibility of the Cuban exiles proved to be assets to their survival in their new country. These qualities have been incorporated into the design solution: The folding panels high-lighted in yellow in the floor plan can be used to divide the floor area into two units, in order to allow more than one artist to work within the same space. This flexibility permits the space to be adapted either into one large unit or two individual units by maintaining the sliding panels in their closed position.

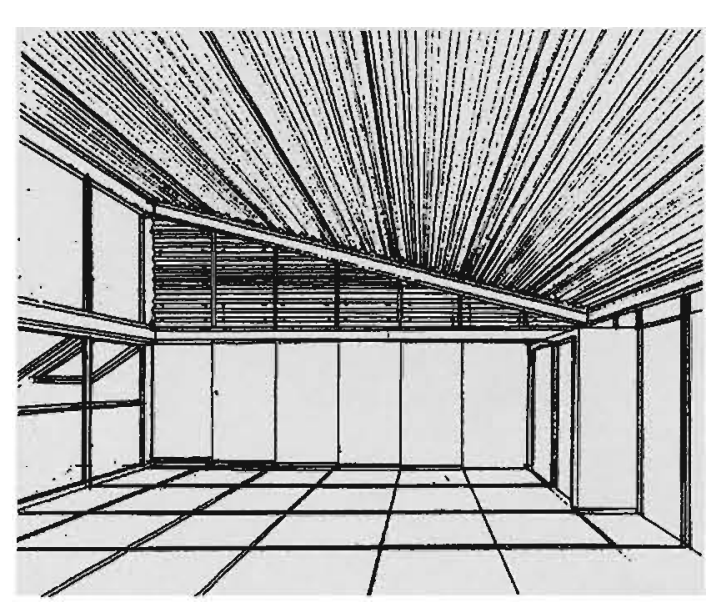

Figure 95. Interior of studio closed.

Figure 94 Floor Plan

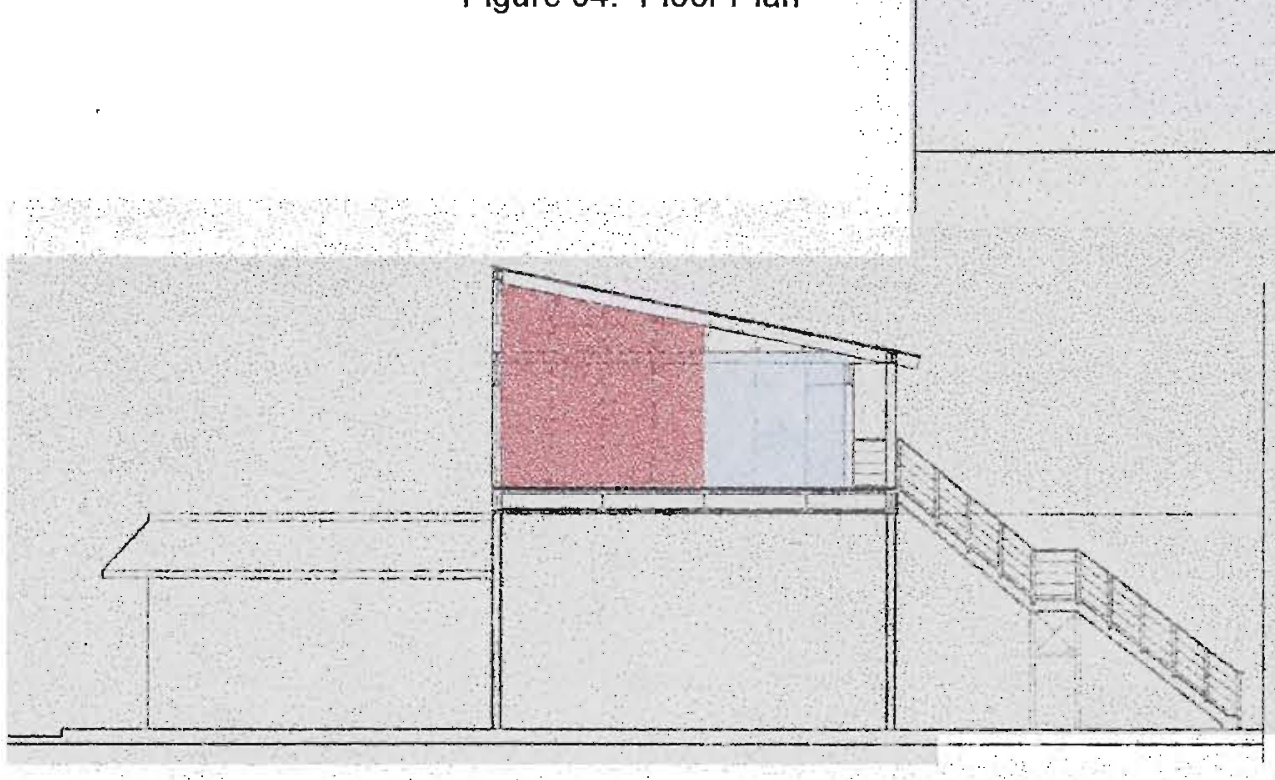

Figure 96. Section

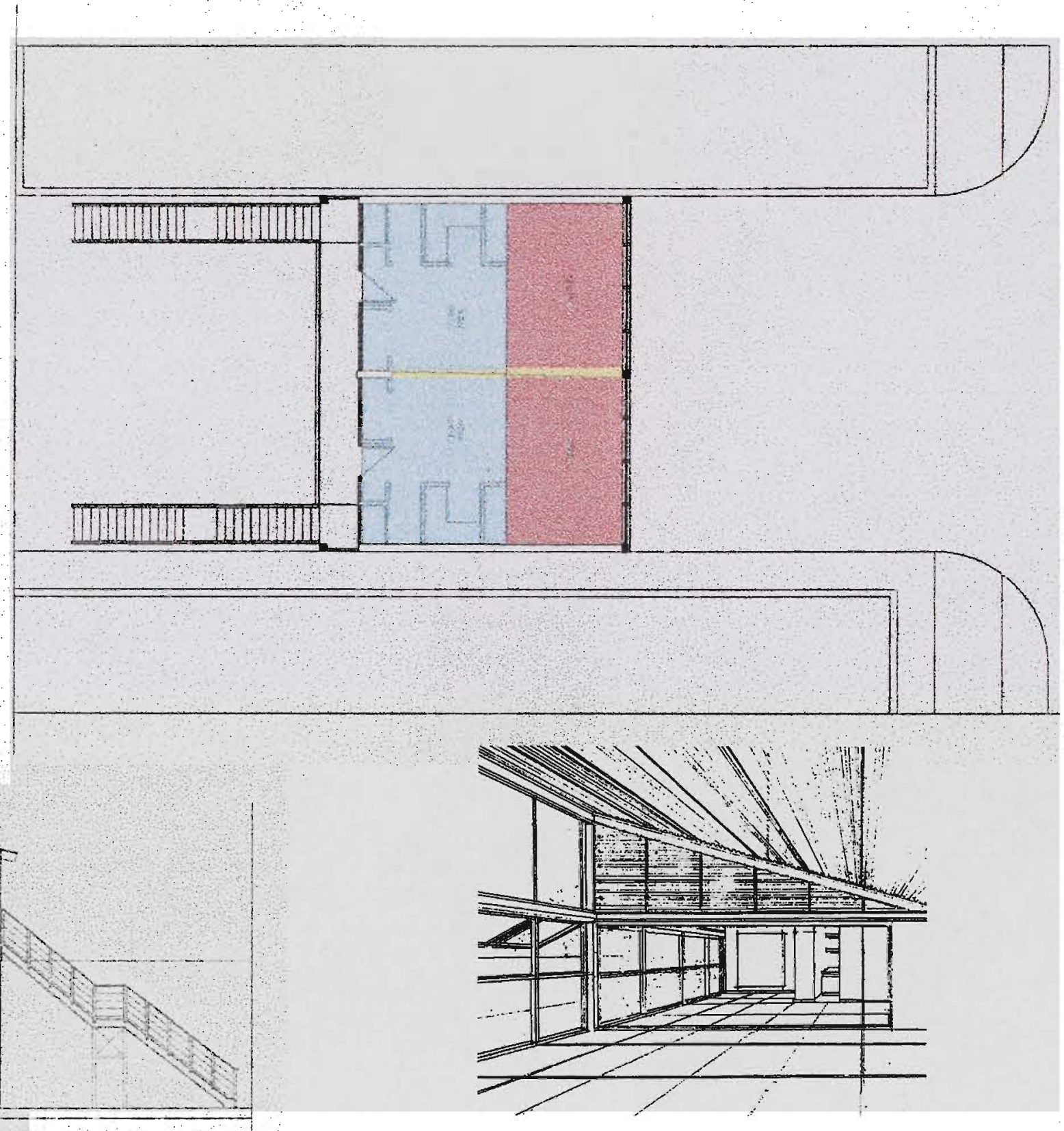

Figure 97. Interior of studio opened 


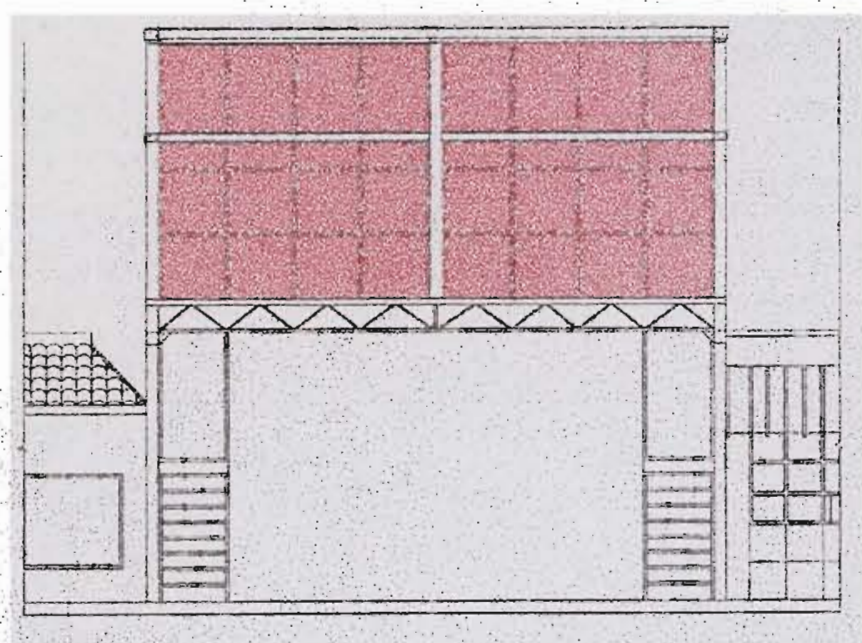

Figure 98. North Elevation.

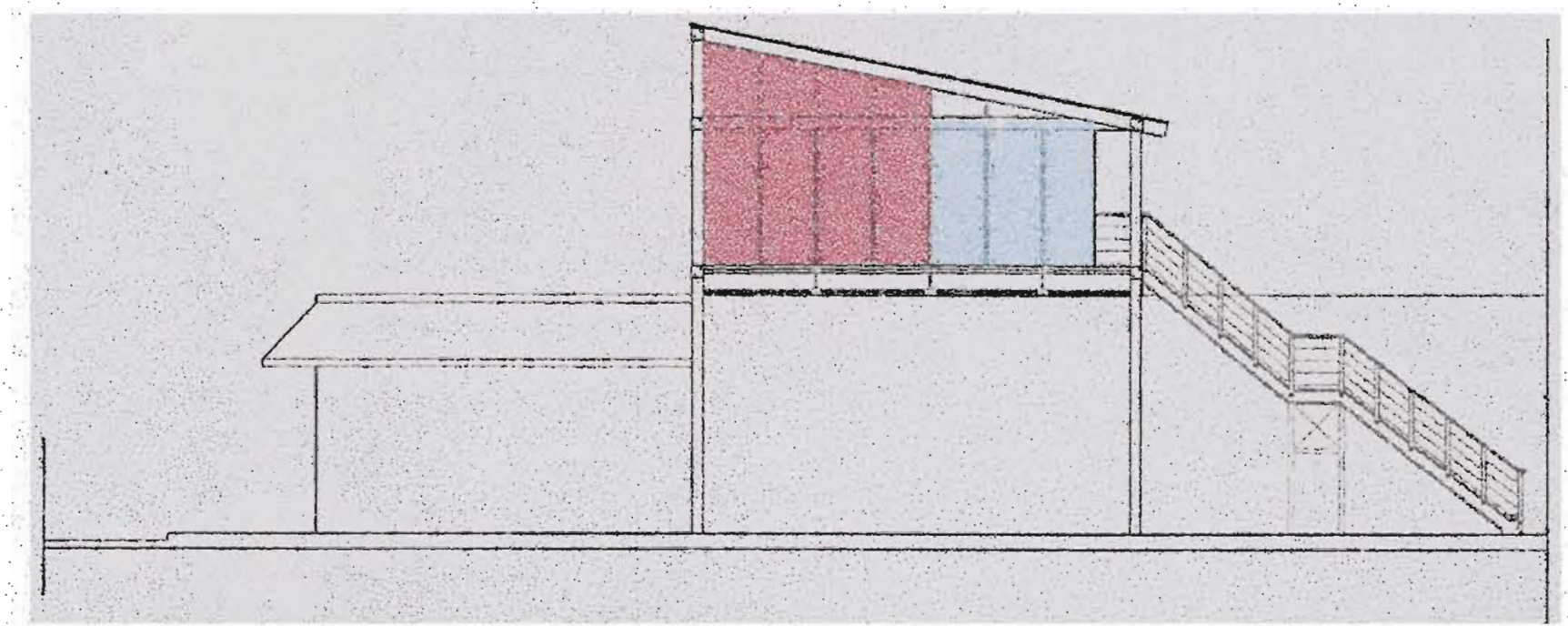

Figure 99. East Elevation. 


\section{SITE 3: 1341 S.W. $8^{\text {TH }}$ STREET}
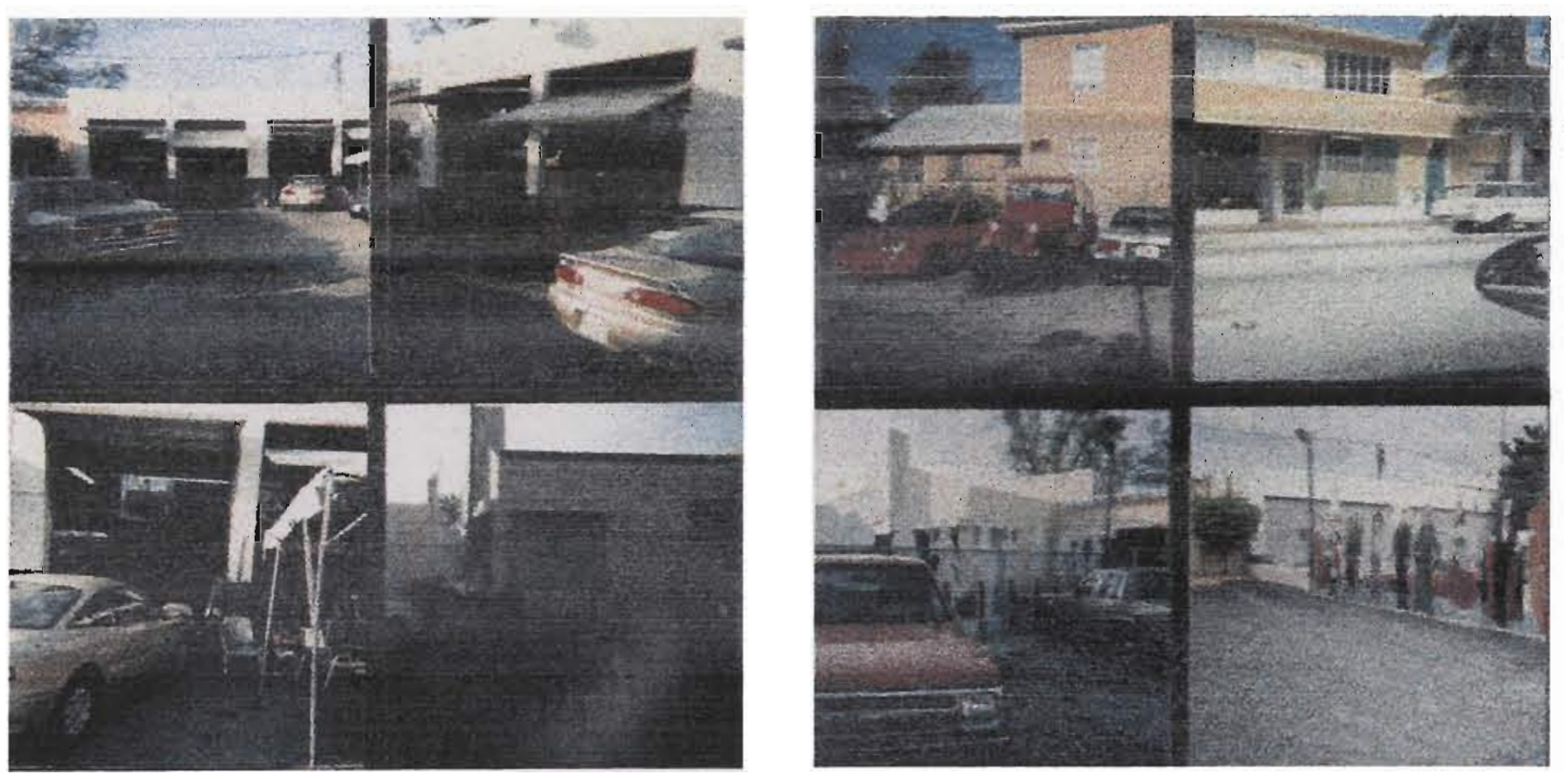

Figure 100. Site Photos

Site 3 is located in the middle of $13^{\text {th }}$ Avenue on the north side of Eighth Street. The structure was built in 1942 at that time it was occupied by the Wendel Filling Station until 1957. In 1957 it became Tony and Dick Auto Service until 1973. Today it still remains an auto repair shop.

The existing concrete block structure measures 50' along Eighth Street by $30^{\prime}$ 'deep into the lot. It sits back on the $75^{\prime} \times 120^{\prime}$ lot creating a large empty space on its south side adjacent to Eighth Street. It's 16' high ceilings were considered advantageous when designing the artist's studios.

The site was selected because it is in need of major repairs. Its location is also ideal; on the east there is a small colony of artists' studios and residences as well as an antique shop. Located to the west of the lot is the Casa de Los Trucos a custom shop operating on Eighth Street since 1970 


\section{SITE3: PROCESS}

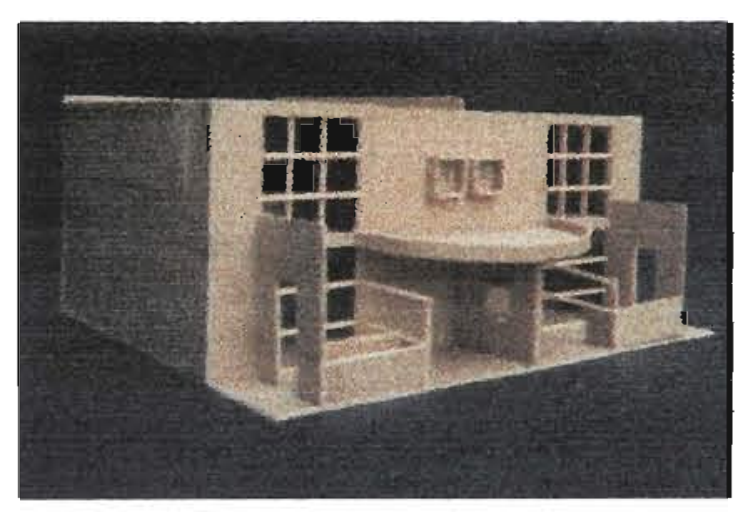

Figure $101 \& 102$ Preliminary model.

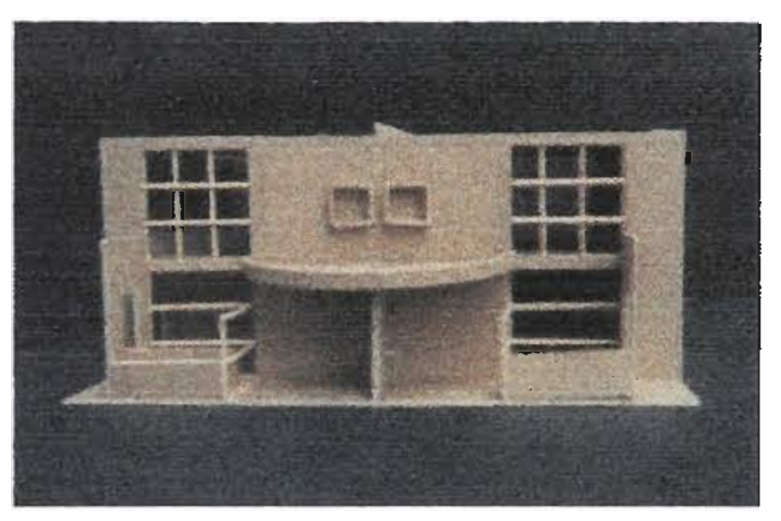

The artists' studios designed on this site were to incorporate the Cuban ethnic elements of commnity, flexabltity and production.

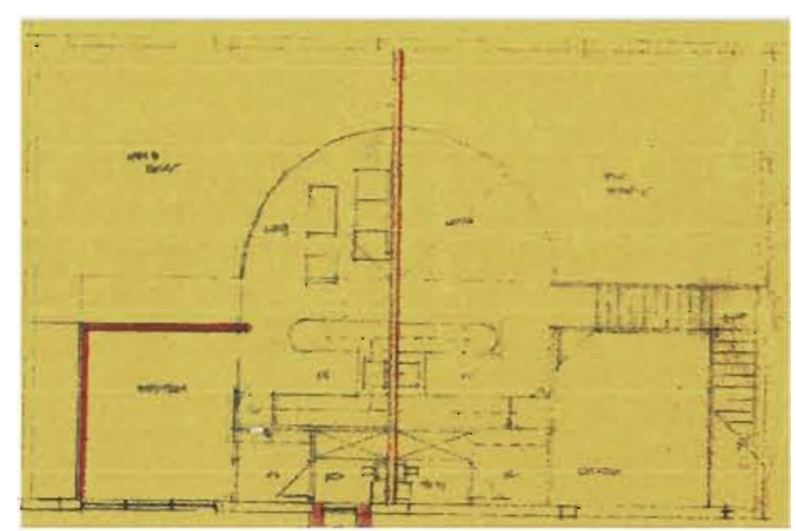

Figure 104. Preliminary Plan.

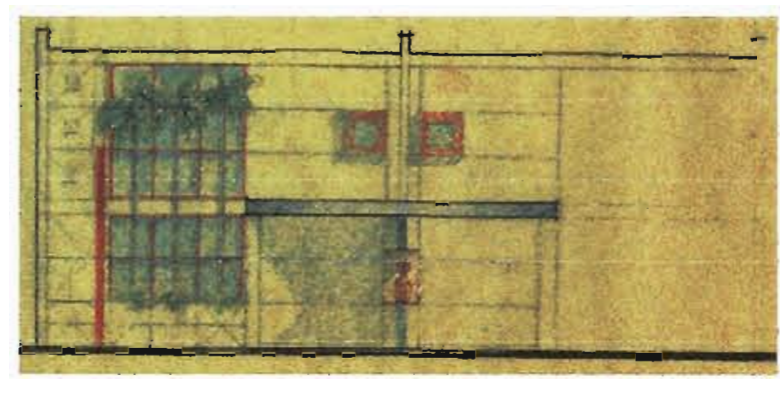

Figure 105. Preliminary Elevation.

The simple rectangular box-like structure offered a challenge. The first preliminary solution, as seen above dealt with a series of articulations in the front

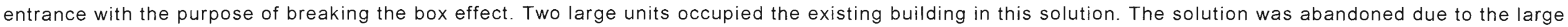

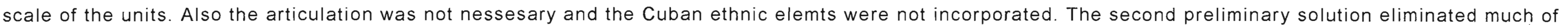

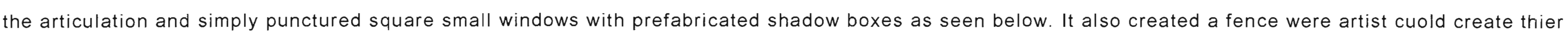

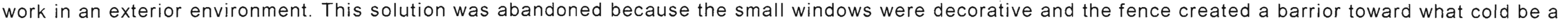
potential meeting place for the community

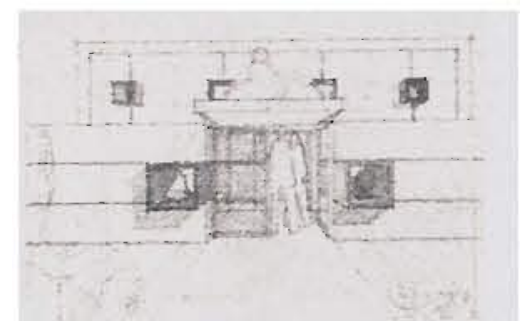

Figure 106. Exterior Prespective.

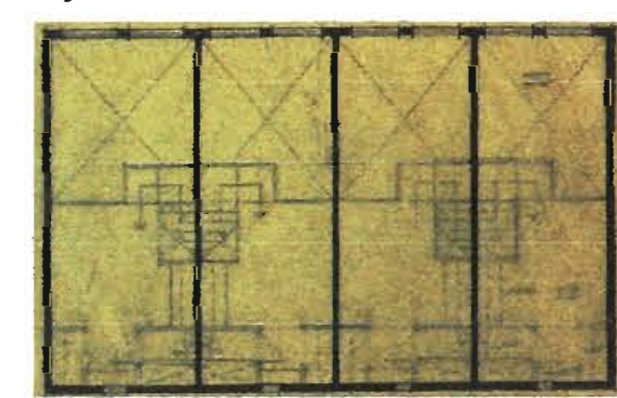

Figure 107. Plans.

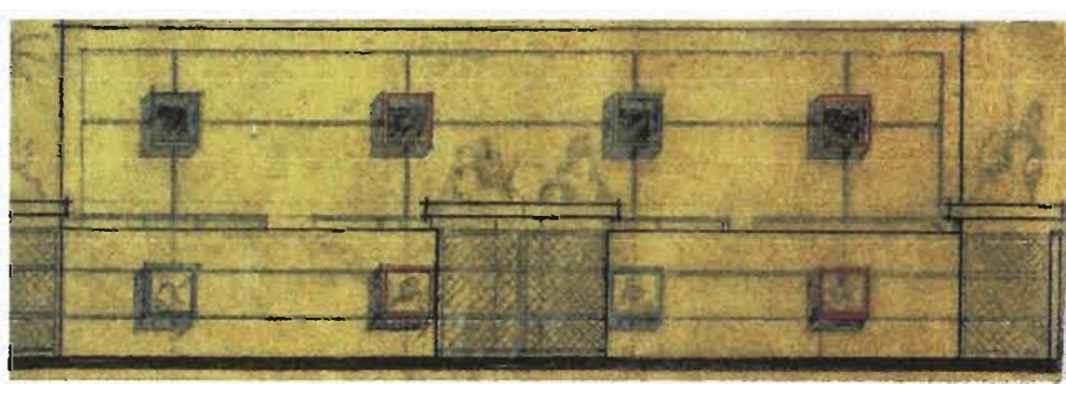

Figure 108. Front Elevation.

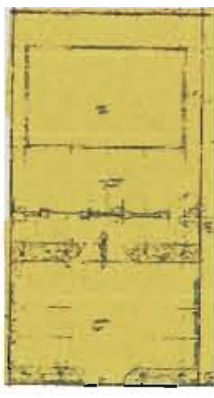

Figure 109. Site Plan 


\section{SITE 3: PROPOSED DESIGN SOLUTION}

Site 3 incorporated the following ethnic Cuban elements into the design solution:

- Strong relationship to the street/Community

- Production

- Flexability

Strong Relation to the Street/Community

The existing building on the site sits to the north

This creates a plaza space in the front of the building.

The area can be used to conduct community meetings or artist's exhibits. The plaza is indicated by the green screen on the site plan. This space can become a place were artist can share ideas similar to the function of the cafe windows along Calle Ocho.

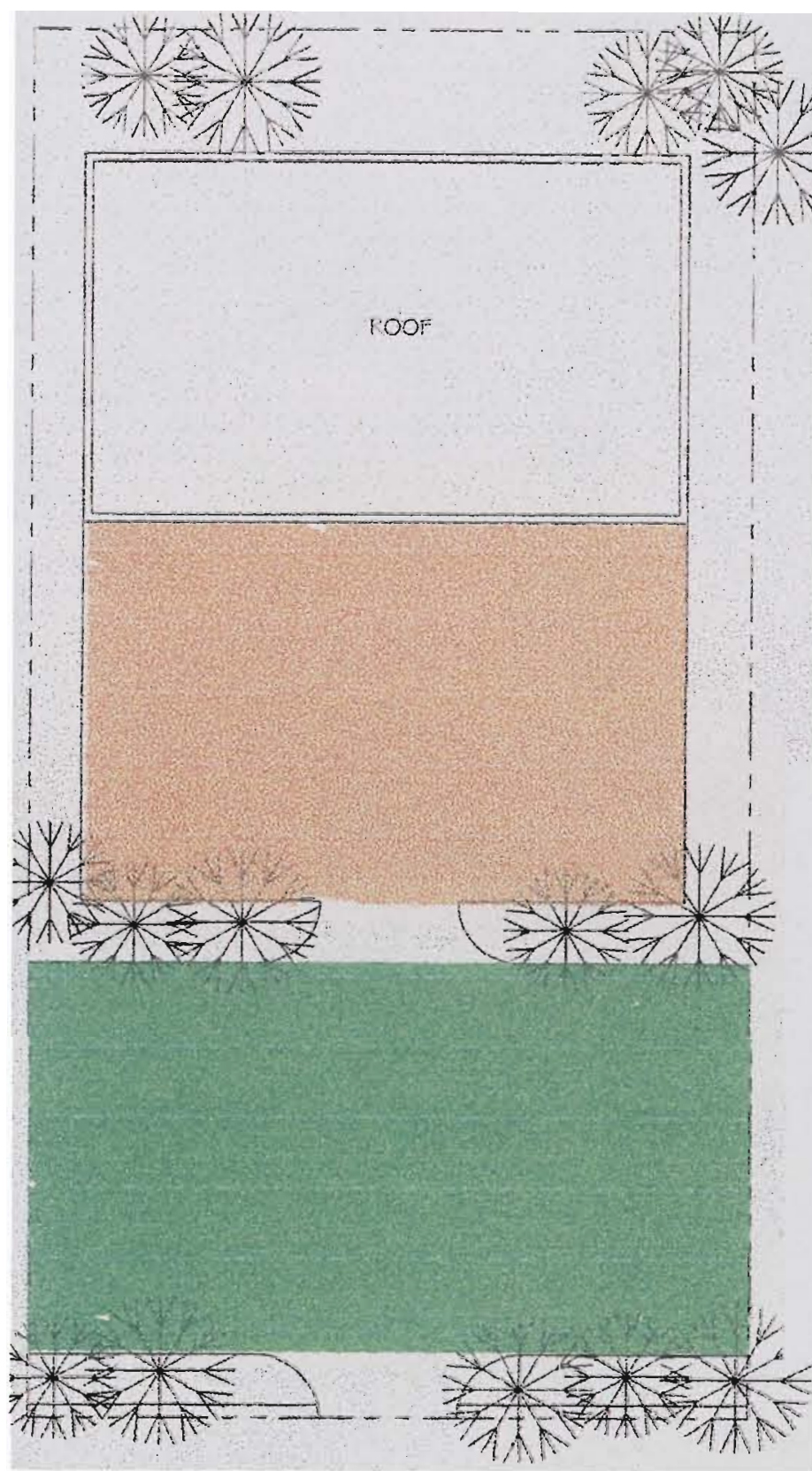

Figure 111. Site Plan.

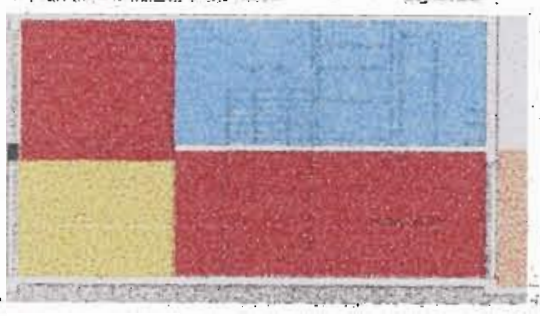

Figure 110. Section

\section{LEGEND:}

1. STudos

TIWNG AREAS

PROOUCTION. EXTER:OR LIVHG AREAS

STRONG RELATIONSHIP THET. EXTERION GALLERY AREAS

FLEXIBIUTY
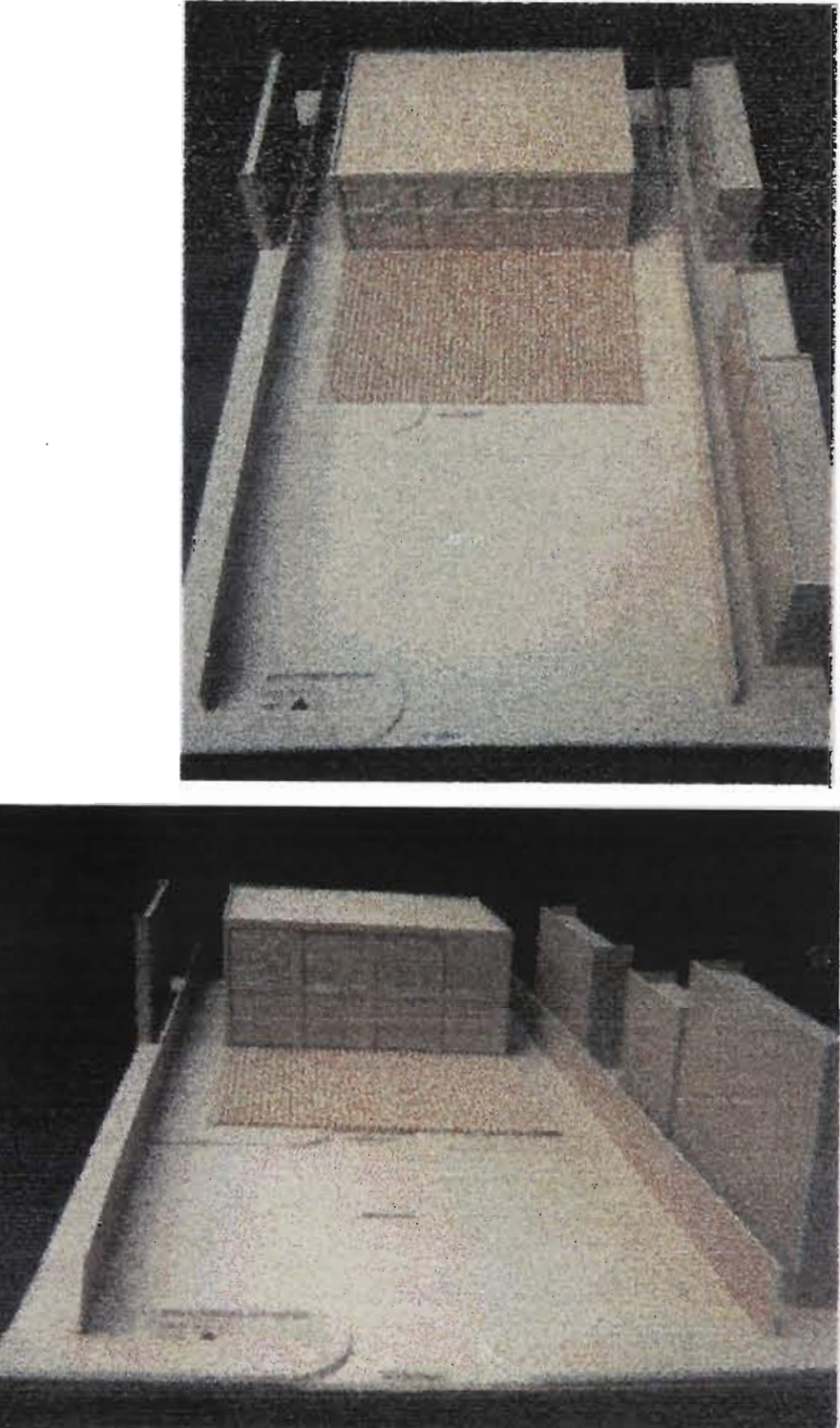

Figure 112 \&113. Plaza and Production Space can be seen in front of the building. 


\section{Production:}

The exterior studio areas provided in the south side of the existing building. Areas noted by the peach colored screen in the site plan and floor plan create a space were pedestrians can observe the artist at work. This relationship is similar to the pedestrians as they observe the skilled tobacco manufacturers in their craft

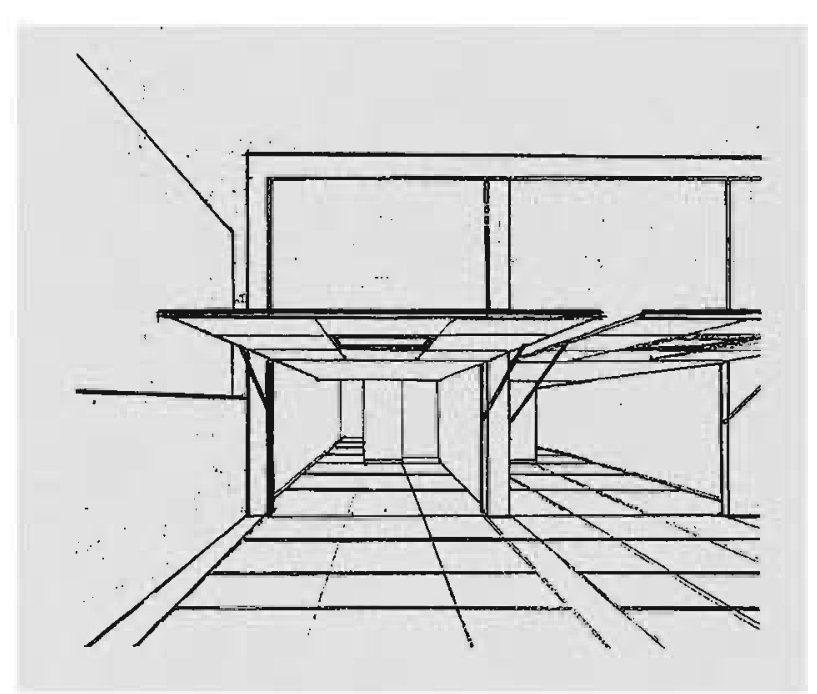

Figure 114. Exterior studio work area.

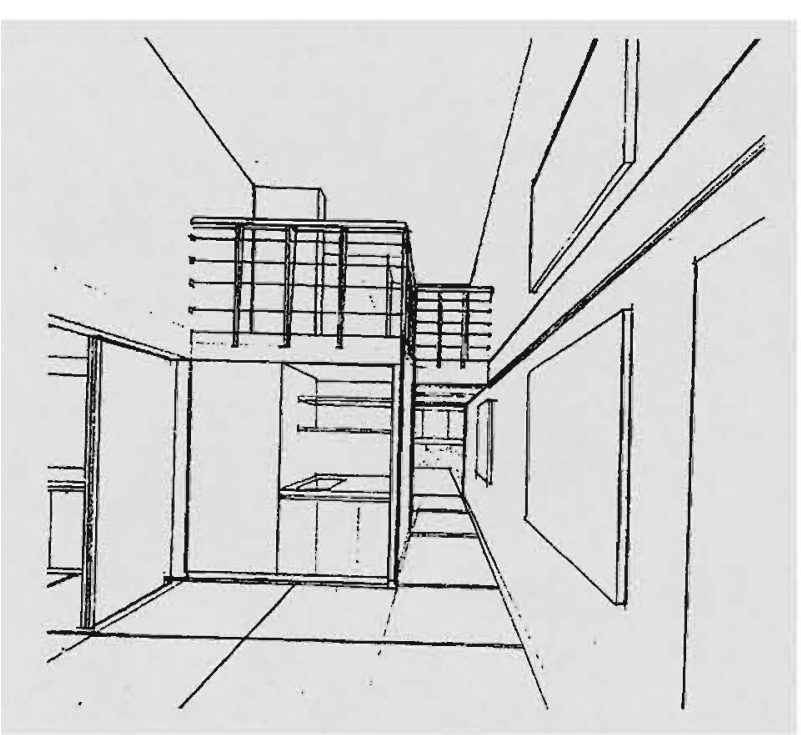

Figure 116. Interior Studio Area.

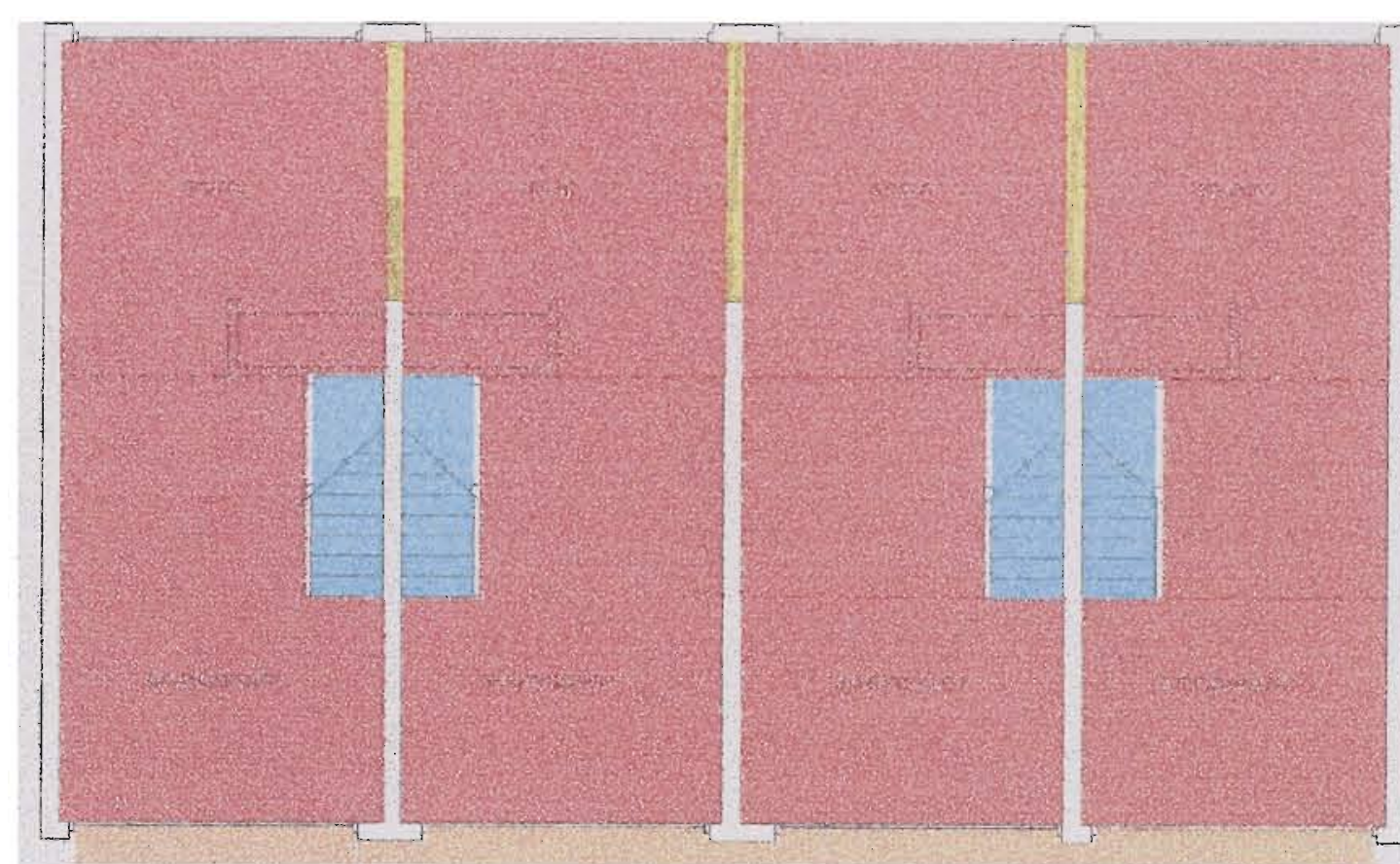

Figure 115. First Floor Plan

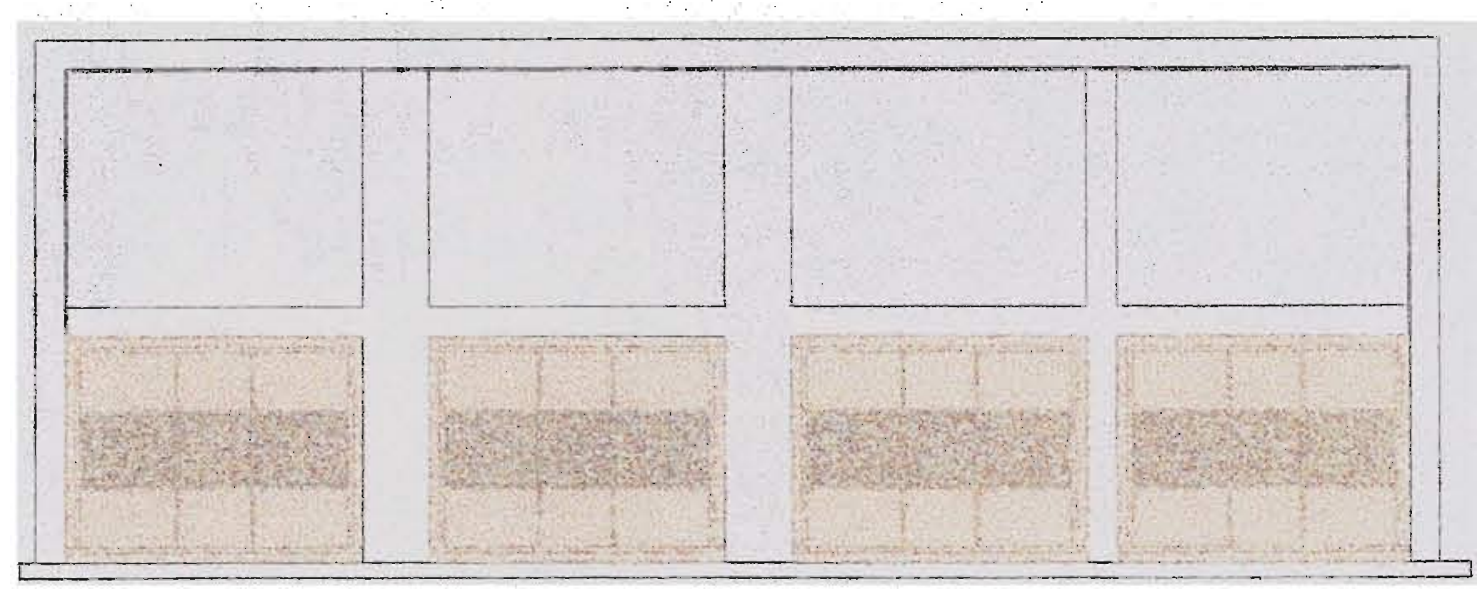

Figure 117. South Elevation. 
Flexibility

The flexibility and adaptability of the Cuban exiles proved to be an asset for their community. Cubans adapted the buildings on Eighth Street to serve their needs. The development of the cafe window is a great example of this ethnic quality.

\section{Artist's studios were designed to offer a similar}

flexibility. The studios located on the north side of the

building can be opened by a system of sliding panels.

The studio space could work as individual

or a large common space.
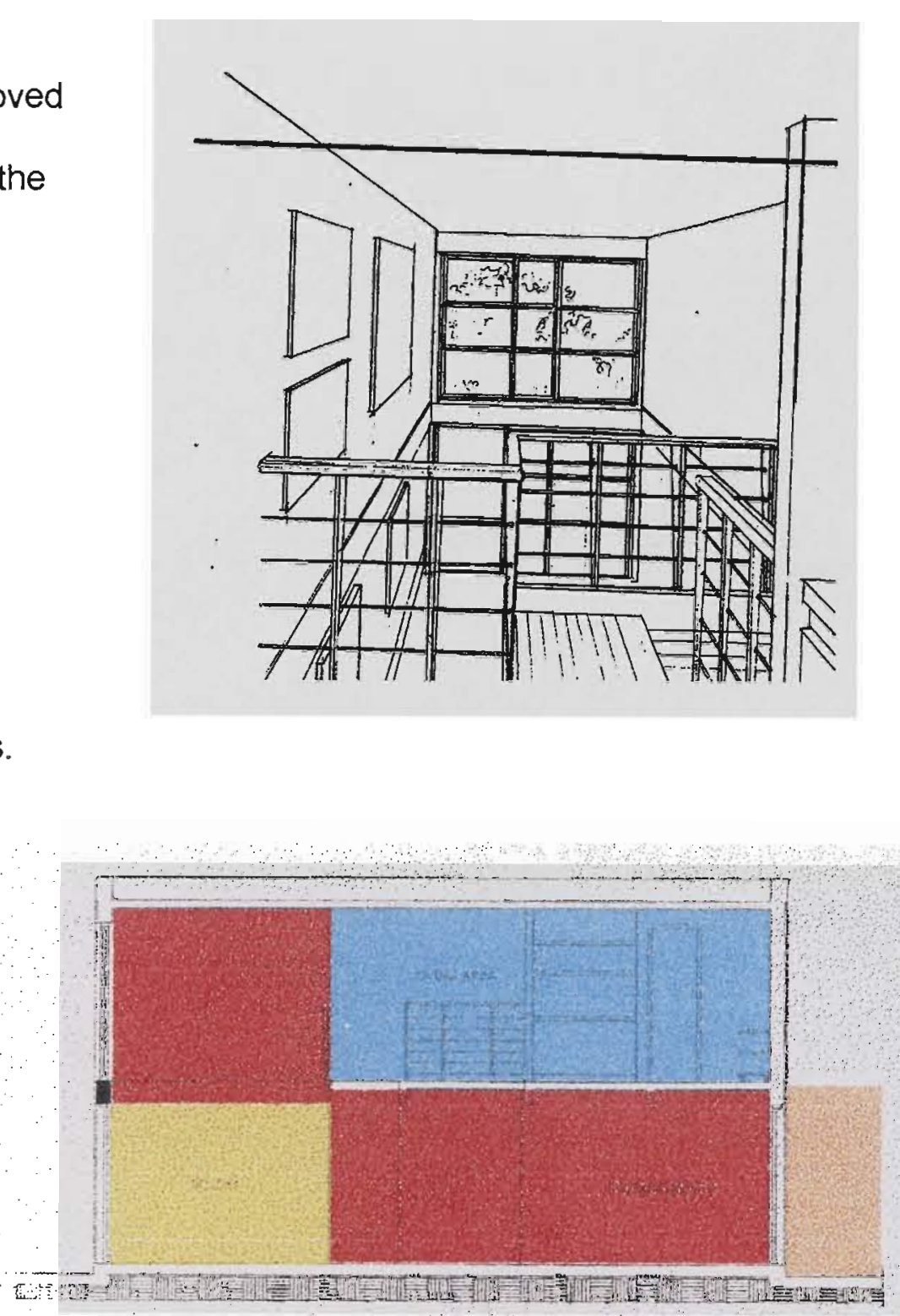

Figure 118 \& 119. Perspective of Loft above, Section below.
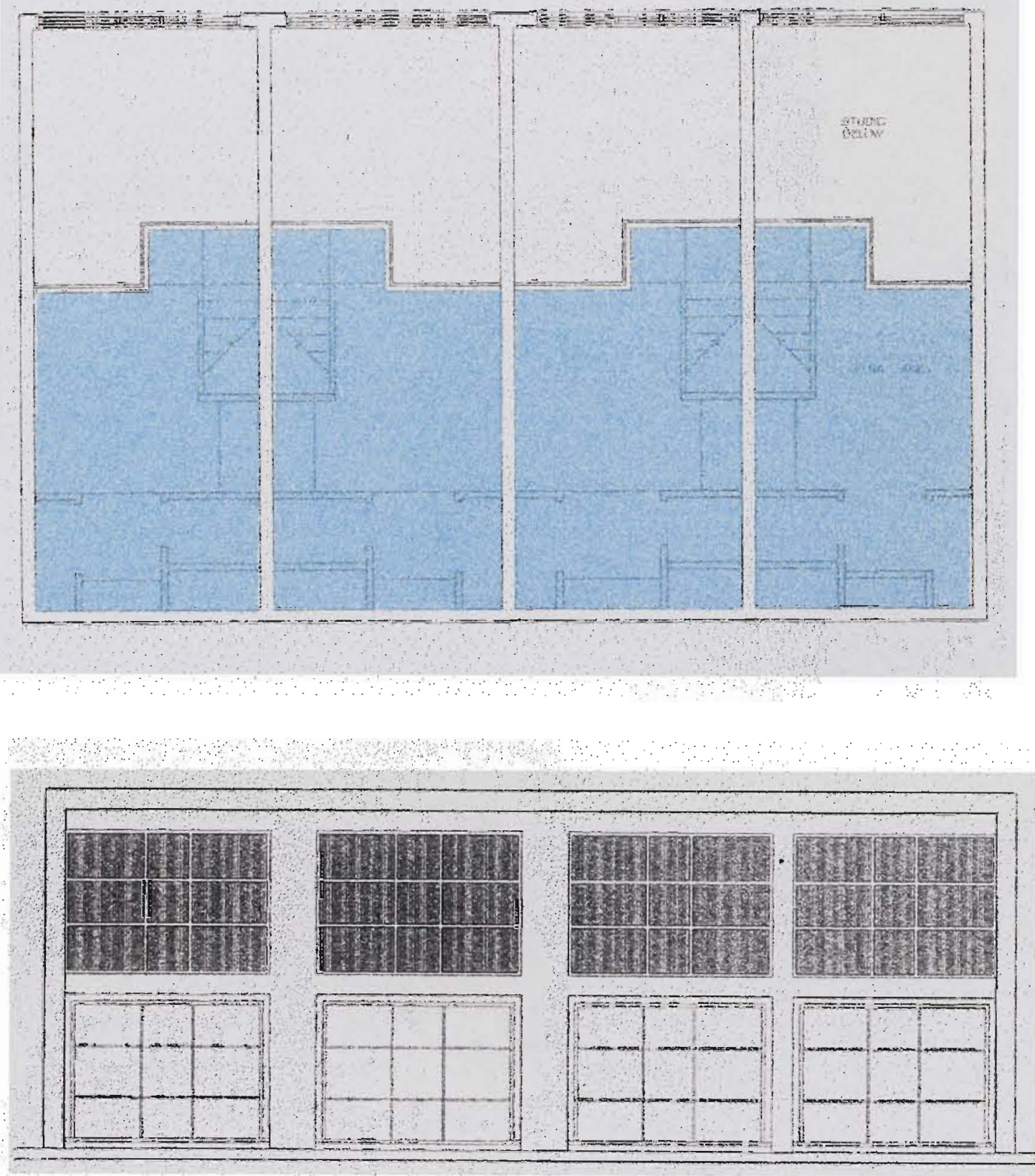

Figure 120 \& 121. Loft Plan above, North Elevation below. 


\section{CONCLUSION:}

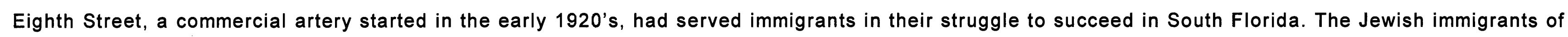

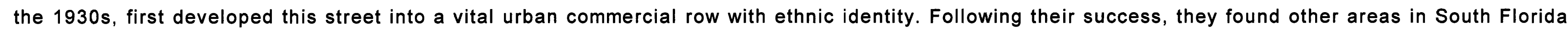
to continue their lives.

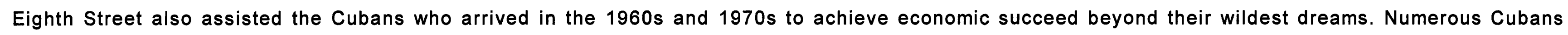

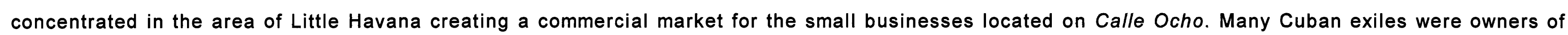

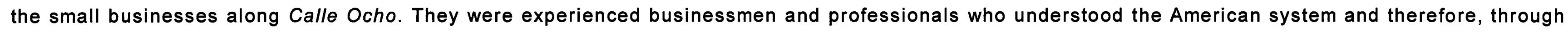

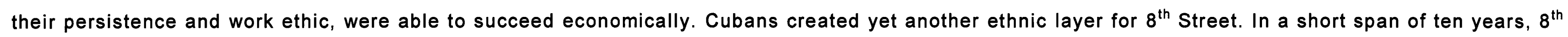
Street was transformed into Calle Ocho.

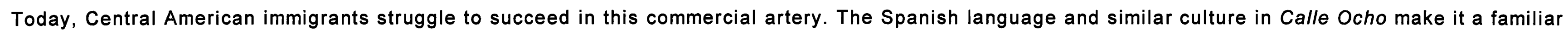
environment for the new Central American immigrants. This change is evident by the many ethnic shops now catering to the Central American culture.

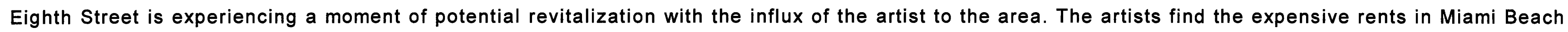

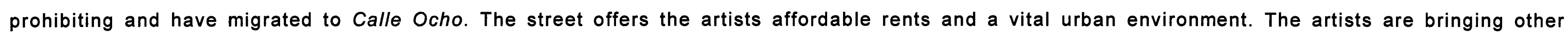
related business such as galleries and antique shops to the street. 


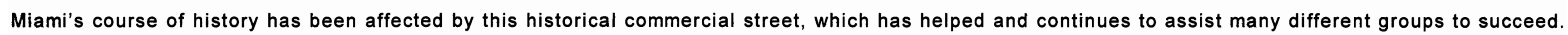

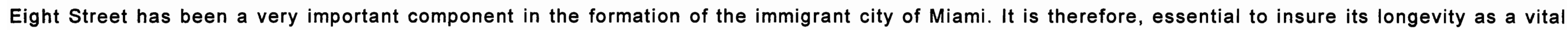
urban organism.

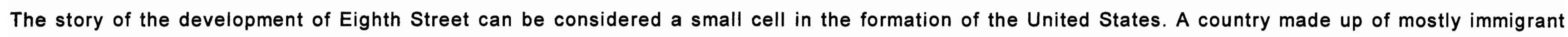

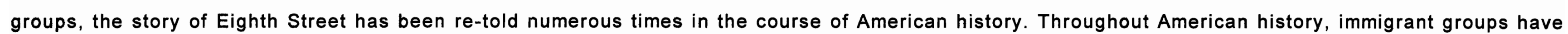
traditionally formed ethnic neighborhoods. These ethnic neighborhoods offer a transition into mainstream society. 